DOE/EIA-0573(95)

Distribution Category UC-950

\title{
Emissions of Greenhouse Gases in the United States 1995
}

\author{
October 1996
}

\section{Energy Information Administration}

Office of Integrated Analysis and Forecasting

U.S. Department of Energy

Washington, DC 20585
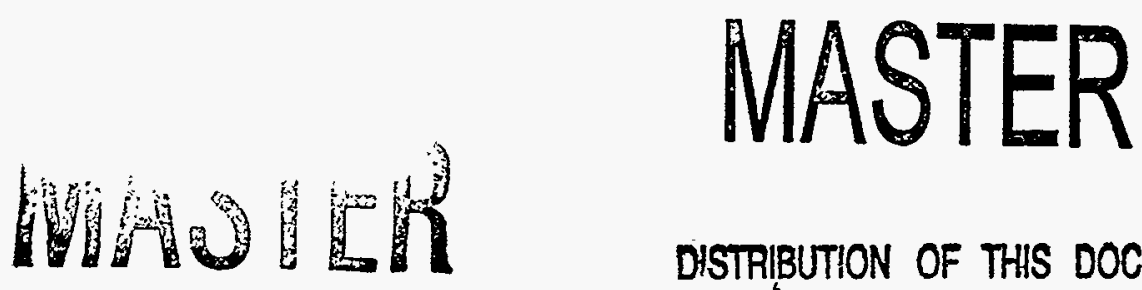

This report was prepared by the Energy Information Administration, the independent statistical and analytical agency within the Department of Energy. The information contained herein should not be construed as advocating or reflecting any policy position of the Department of Energy or of any other organization. 


\section{Contacts}

This report, Emissions of Greenhouse Gases in the United States 1995, was prepared under the general direction of Mary J. Hutzler, Director of the Office of Integrated Analysis and Forecasting, Energy Information Administration. General questions concerning the content of this report may be referred to Arthur T. Andersen, Director of the Energy Demand and Integration Division (202/ 586-1441).
Specific technical information concerning the content of the report may be obtained from Louise Guey-Lee (202/586-1156, e-mail lgueylee@eia.doe.gov). This report was written by Arthur Rypinski (Chapters 1 and 5), Louise Guey-Lee (Chapters 2 and 6), Michael Mondshine (Chapter 3), and Kenneth Pruitt (Chapters 4 and 7). 
DISCLAIMER

Portions of this document may be illegible in electronic image products. Images are produced from the best available original document. 


\section{Preface}

Title XVI, Section 1605(a) of the Energy Policy Act of 1992 (enacted October 24, 1992) provides:

Not later than one year after the date of the enactment of this Act, the Secretary, through the Energy Information Administration, shall develop, based on data available to, and obtained by, the Energy Information Administration, an inventory of the national aggregate emissions of each greenhouse gas for each calendar year of the baseline period of 1987 through 1990. The Administrator of the Energy
Information Administration shall annually update and analyze such inventory using available data. This subsection does not provide any netw data collection authority.

The first report in this series; Emissions of Greenhouse Gases 1985-1990, was published in September 1993. This report-the fourth annual report, as required by lawpresents the Energy Information Administration's latest estimates of emissions for carbon dioxide, methane, nitrous oxide, and other greenhouse gases. 


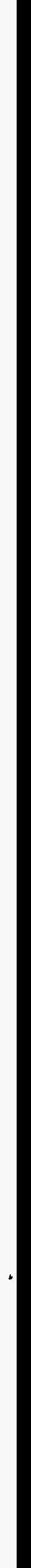




\section{Contents}

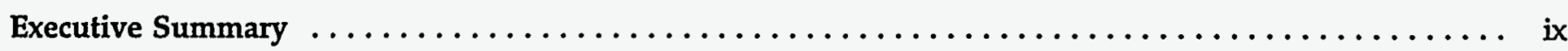

1. U.S. Emissions of Greenhouse Gases in Perspective $\ldots \ldots \ldots \ldots \ldots \ldots \ldots \ldots \ldots \ldots \ldots \ldots \ldots \ldots$

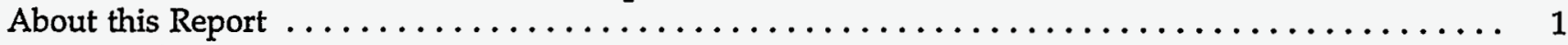

The Greenhouse Effect and Global Climate Change $\ldots \ldots \ldots \ldots \ldots \ldots \ldots \ldots \ldots \ldots \ldots \ldots \ldots$

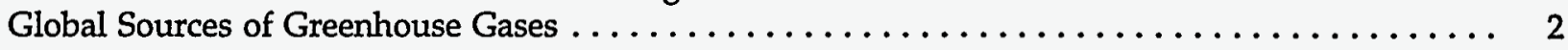

Relative Forcing Effects of Various Gases $\ldots \ldots \ldots \ldots \ldots \ldots \ldots \ldots \ldots \ldots \ldots \ldots \ldots$

Global Climate Change Policy Developments $\ldots \ldots \ldots \ldots \ldots \ldots \ldots \ldots \ldots \ldots \ldots \ldots \ldots \ldots \ldots$

U.S. Emissions in an International Perspective $\ldots \ldots \ldots \ldots \ldots \ldots \ldots \ldots \ldots \ldots \ldots \ldots \ldots \ldots$

2. Carbon Dioxide Emissions $\ldots \ldots \ldots \ldots \ldots \ldots \ldots \ldots \ldots \ldots \ldots \ldots \ldots \ldots \ldots \ldots \ldots \ldots \ldots \ldots \ldots$

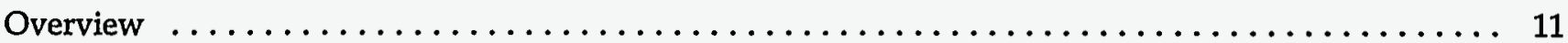

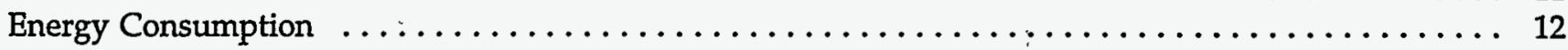

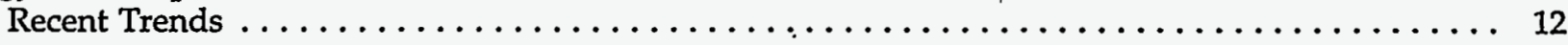

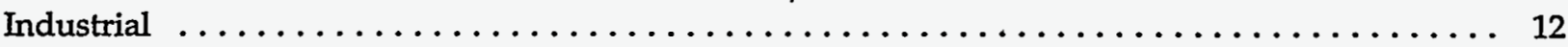

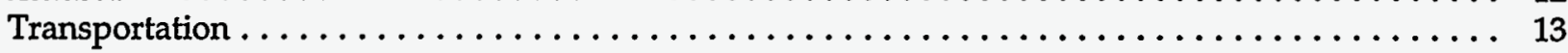

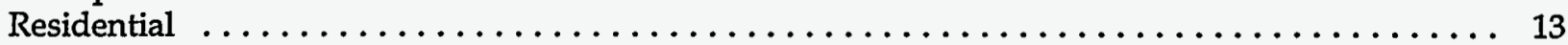

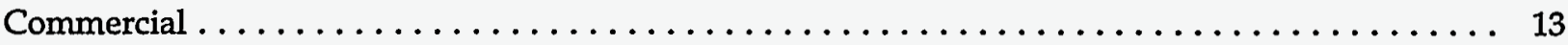

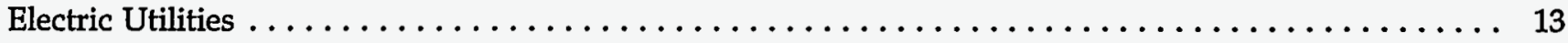

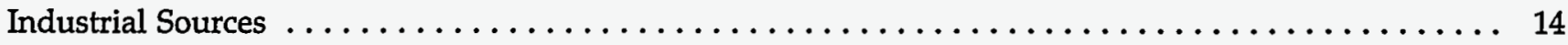

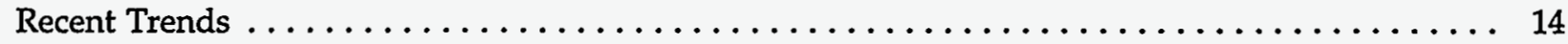

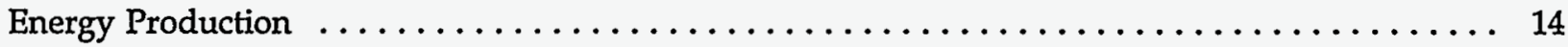

Industrial Processes . . . . . . . . . . . . . . . . . . .

Adjustments to Energy Consumption $\ldots \ldots \ldots \ldots \ldots \ldots \ldots \ldots \ldots \ldots \ldots \ldots \ldots \ldots \ldots \ldots \ldots \ldots \ldots$

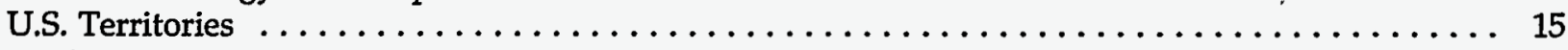

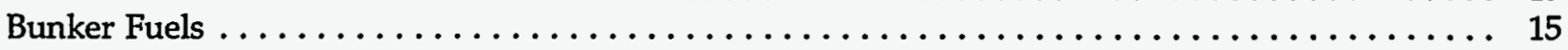

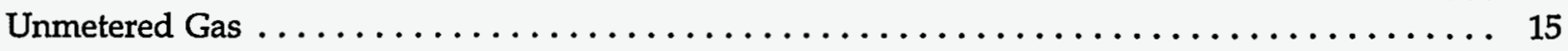

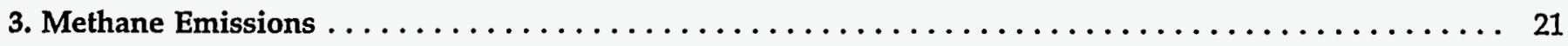

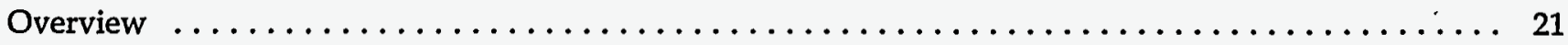

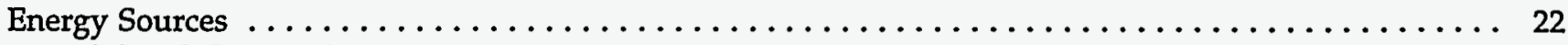

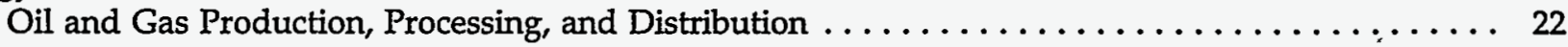

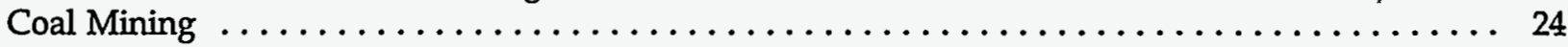

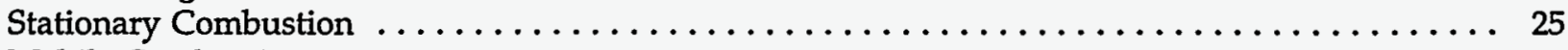

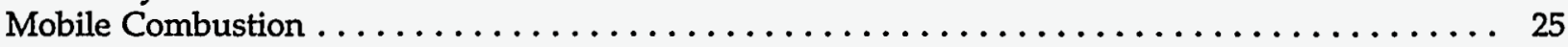

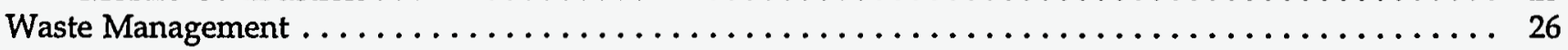

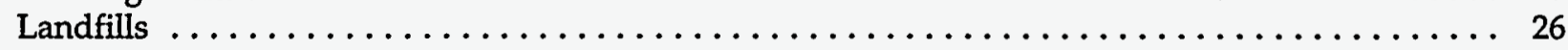

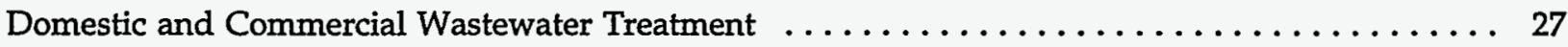

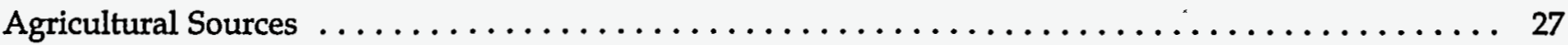

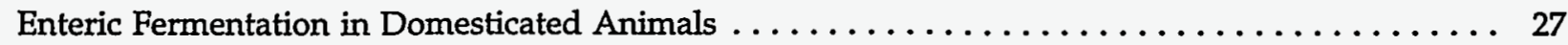

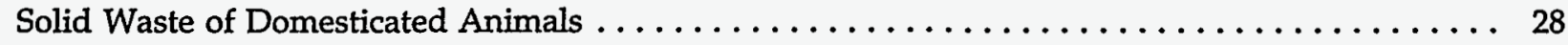

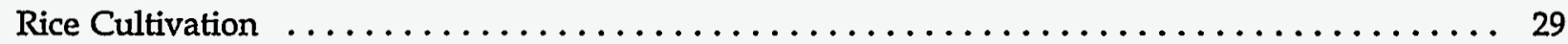

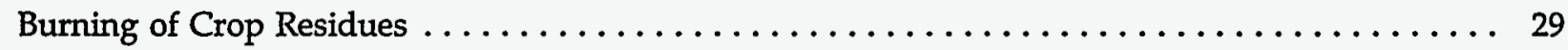

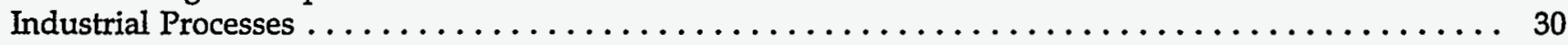

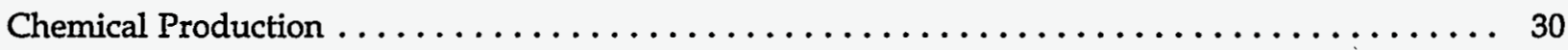

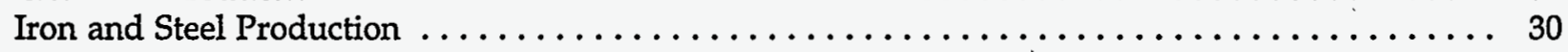


4. Nitrous Oxide Emissions $\ldots \ldots \ldots \ldots \ldots \ldots \ldots \ldots \ldots \ldots \ldots \ldots \ldots \ldots \ldots \ldots \ldots \ldots \ldots \ldots \ldots \ldots$

Overview $\ldots \ldots \ldots \ldots \ldots \ldots \ldots \ldots \ldots \ldots \ldots \ldots \ldots \ldots \ldots \ldots \ldots \ldots \ldots \ldots \ldots \ldots \ldots \ldots$

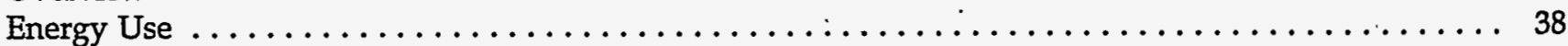

Recent Trends $\ldots \ldots \ldots \ldots \ldots \ldots \ldots \ldots \ldots \ldots \ldots \ldots \ldots \ldots \ldots \ldots \ldots \ldots \ldots \ldots \ldots$

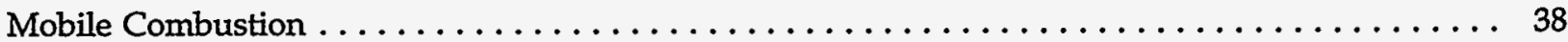

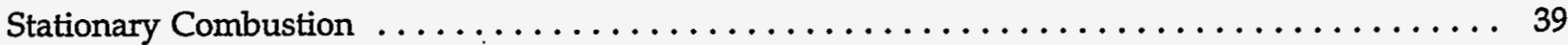

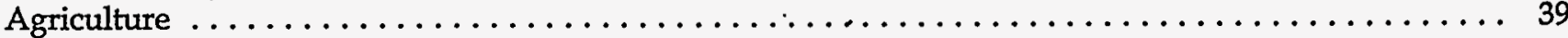

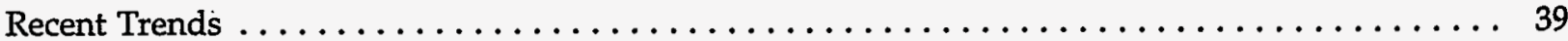

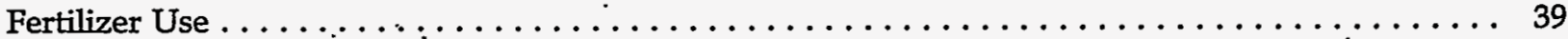

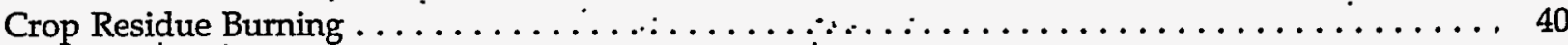

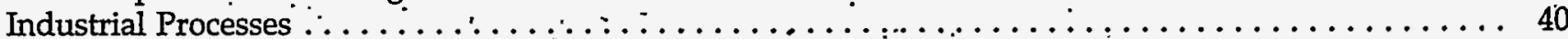

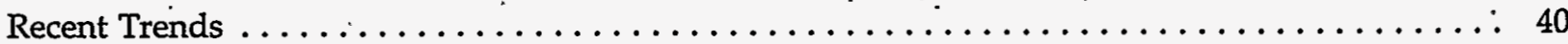

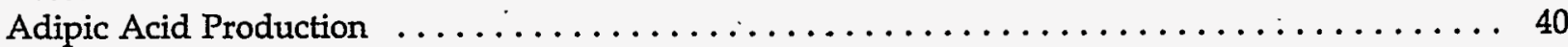

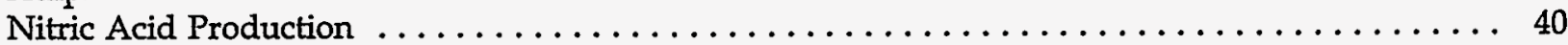

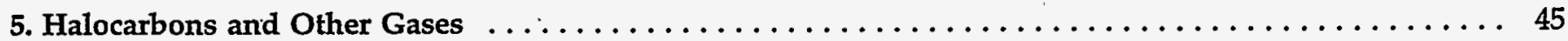

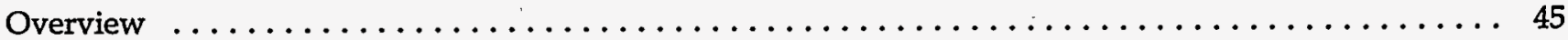

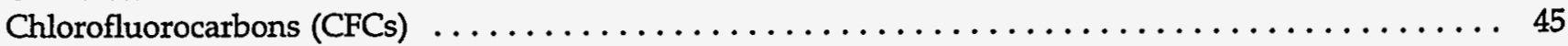

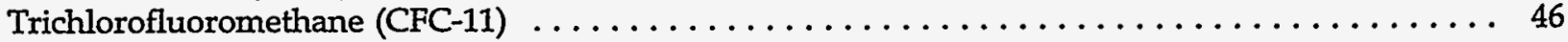

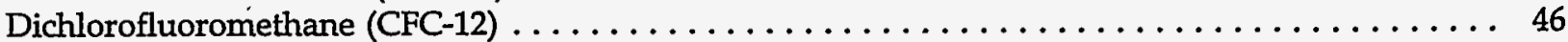

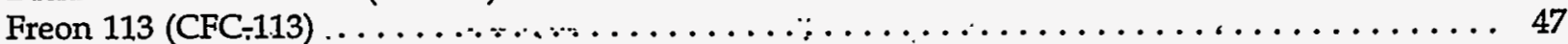

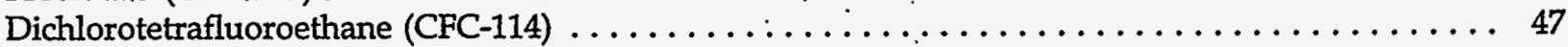

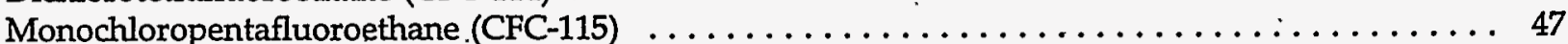

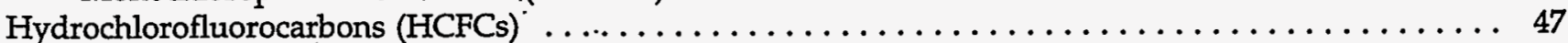

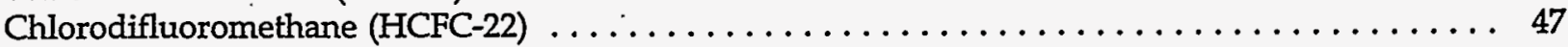

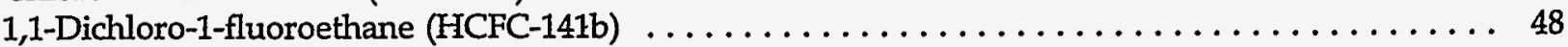

Chlorodifluoroethane (HCFC-142b) $\ldots \ldots \ldots \ldots \ldots \ldots \ldots \ldots \ldots \ldots \ldots \ldots \ldots \ldots$

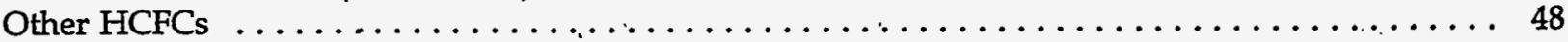

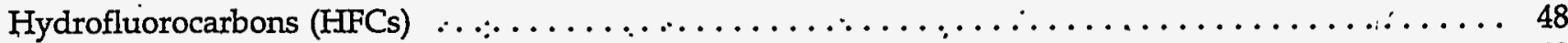

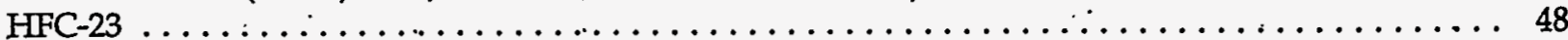

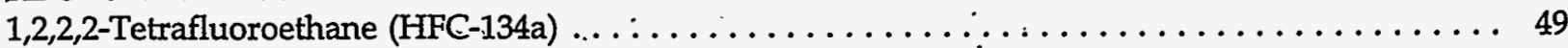

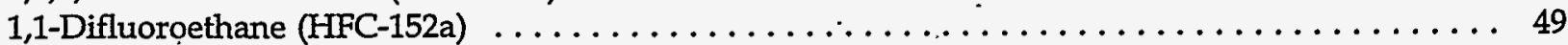

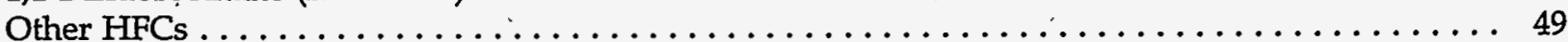

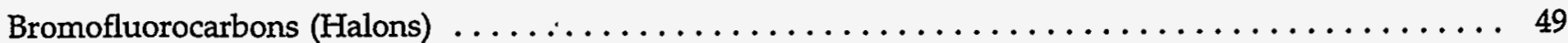

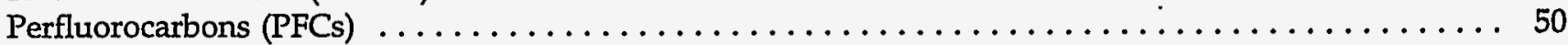

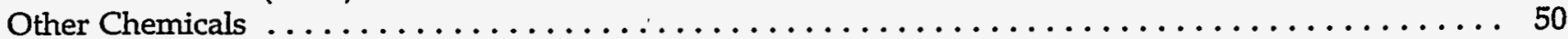

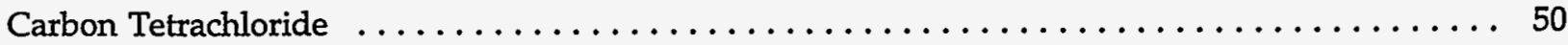

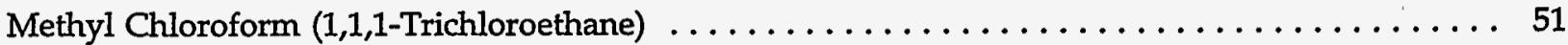

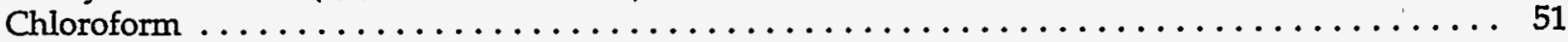

Methylene Chloride (Dichloromethane) $\ldots \ldots \ldots \ldots \ldots \ldots \ldots \ldots \ldots \ldots \ldots \ldots \ldots \ldots \ldots \ldots$

Sulfur Hexafluoride.$\ldots \ldots \ldots \ldots \ldots \ldots \ldots \ldots \ldots \ldots \ldots \ldots \ldots \ldots \ldots \ldots \ldots$

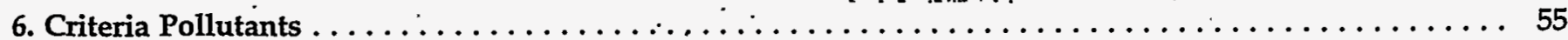

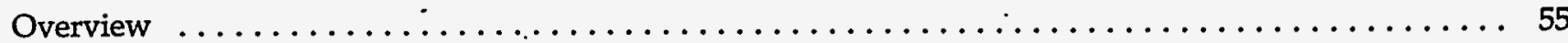

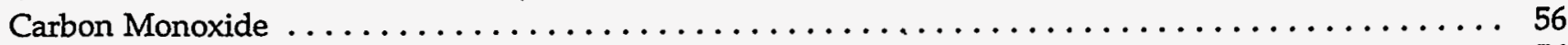

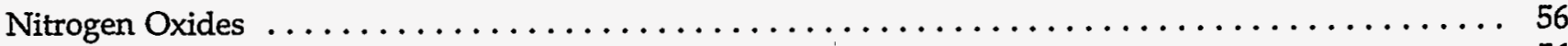

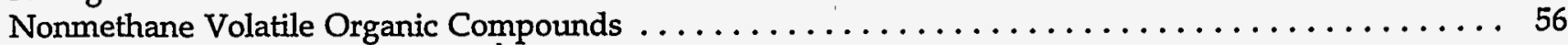

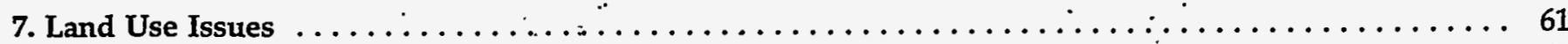

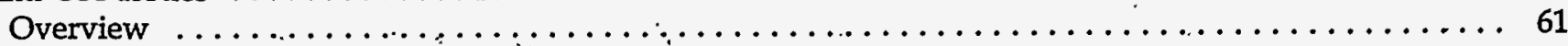

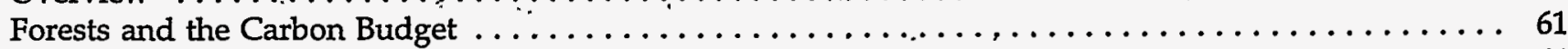

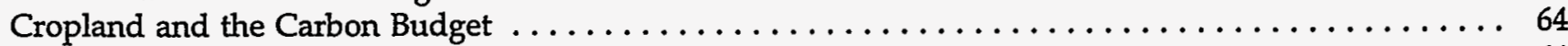

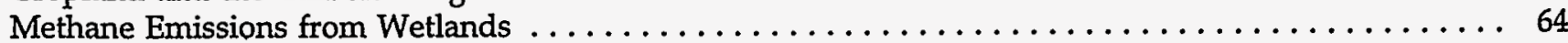

Effects of Land Use Changes on Methane and Nitrous Oxide Emissions . . . . . . . . . . . 64 


\section{Appendixes}

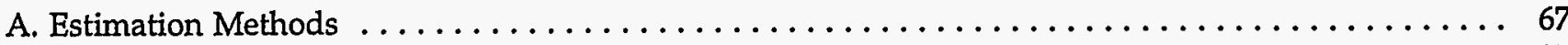

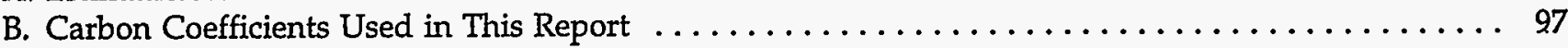

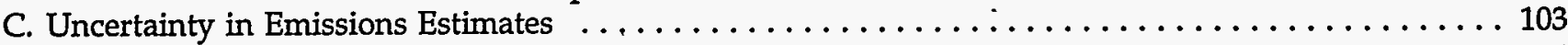

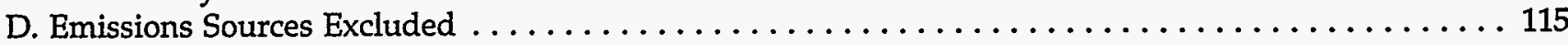

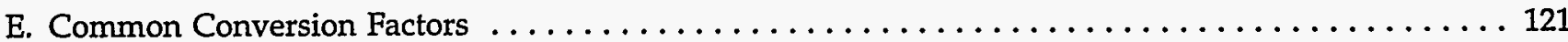

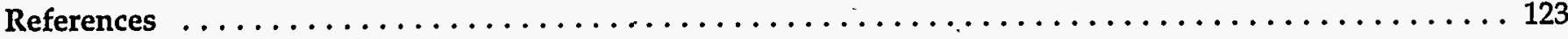

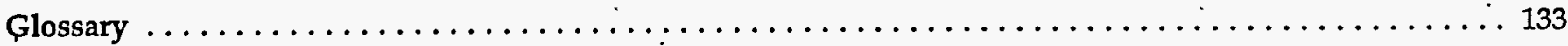

\section{Tables}

ES1. Estimated U.S. Emissions of Greenhouse Gases by Gas, 1988-1995 . . . . . . . . . . . . . . ix

ES2. .U.S. Emissions of Greenhouse Gases, Based on Global Warming Potential, 1988-1995 . . . . . . . . . . . xi

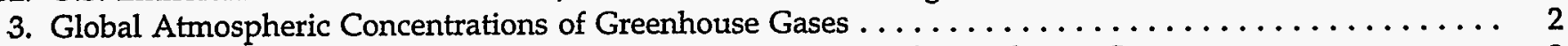

4. Global Natural and Anthropogenic Sources and Absorption of Greenhouse Gases ........... 3

5. Numerical Estimates of Global Warming Potentials Compared With Carbon Dioxide ............. 6

6. Numerical Estimates of Global Warming Potentials, Including Indirect Effects, for Selected Chlorofluorocarbons and Hydrochlorofluorocarbons Compared With Carbon Dioxide . . . . . . . 7

5. U.S. Carbon Dioxide Emissions from Energy and Industry, 1988-1995 . . . . . . . . . . . . . . 16

6. U.S. Carbon Dioxide Emissions from Fossil Energy Consumption by End-Use Sector, 1988-1995 . . . . 16

7. U.S. Carbon Sequestered by Nonfuel Use of Energy, $1988-1995 \ldots \ldots \ldots \ldots \ldots \ldots \ldots \ldots \ldots \ldots \ldots . \ldots 17$

8. U.S. Carbon Dioxide Emissions from Energy Use in the Industrial Sector, 1984-1995 . . . . . . . . . 17

9. U.S. Carbon Dioxide Emissions from Energy Use in the Transportation Sector, 1984-1995 . . . . . . . . 18

10. U.S. Carbon Dioxide Emissions from Energy Use in the Residential Sector, 1984-1995 . . . . . . . . . 18

11. U.S. Carbon Dioxide Emissions from Energy Use in the Commercial Sector, 1984-1995 . . . . . . . . . . 18

12. U.S. Carbon Dioxide Emissions from Electric Utilities, $1984-1995 \ldots \ldots \ldots \ldots \ldots \ldots \ldots \ldots \ldots \ldots$

13. U.S. Carbon Dioxide Emissions from Gas Flaring, $1988-1995 \ldots \ldots \ldots \ldots \ldots \ldots \ldots \ldots \ldots$

14. U.S. Carbon Dioxide Emissions from Industrial Sources, $1988-1995$. . . . . . . . . . . . . . . . . 20

15. Carbon Emissions from U.S. Territories, International Bunkers, and Unmetered Gas Consumption,

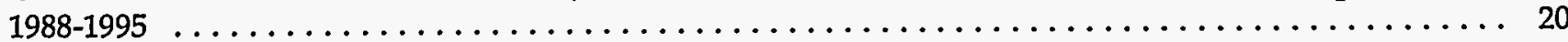

16. U.S. Methane Emissions from Anthropogenic Sources, $1988-1995 \ldots \ldots \ldots \ldots \ldots \ldots \ldots \ldots \ldots \ldots \ldots$

17. U.S. Methane Emissions from Oil and Gas Operations, $1988-1995 \ldots \ldots \ldots \ldots \ldots \ldots \ldots \ldots \ldots \ldots . \ldots \ldots$

18. U.S. Methane Emissions from Coal Mining and Post-Mining Activities, 1988-1995 . . . . . . . . 32

19. U.S. Methane Emissions from Stationary Combustion Sources, $1988-1995 \ldots \ldots \ldots \ldots \ldots \ldots \ldots \ldots \ldots$

20. U.S. Methane Emissions from Mobile Sources, $1988-1995 \ldots \ldots \ldots \ldots \ldots \ldots \ldots \ldots \ldots \ldots \ldots \ldots$

21. U.S. Methane Emissions from Anaerobic Decomposition in Landfills, $1988-1995$. . . . . . . . . . . 34

22. U.S. Methane Emissions from Enteric Fermentation in Domesticated Animals, 1988-1995 . . . . . . . . 35

23. U.S. Methane Emissions from the Solid Waste of Domesticated Animals, 1988-1995 . . . . . . . . . 35

24. Area of Land Harvested for Rice and Estimated U.S. Methane Emissions from Flooded Rice Fields,

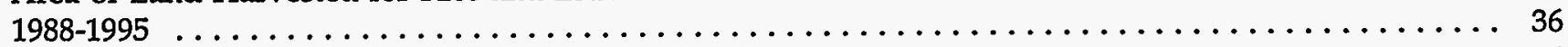

25. U.S. Methane Emissions from Industrial Processes, $1988-1995 \ldots \ldots \ldots \ldots \ldots \ldots \ldots \ldots \ldots \ldots \ldots$

26. Estimated U.S. Emissions of Nitrous Oxide, $1988-1995 \ldots \ldots \ldots \ldots \ldots \ldots \ldots \ldots \ldots \ldots \ldots \ldots \ldots . \ldots \ldots$

27. U.S. Nitrous Oxide Emissions from Mobile Sources, $1988-1995 \ldots \ldots \ldots \ldots \ldots \ldots \ldots \ldots \ldots \ldots \ldots$. . . 41

28. U.S. Nitrous Oxide Emissions from Stationary Combustion Sources, 1988-1995 . . . . . . . . . . . 42

29. U.S. Nitrous Oxide Emissions from Nitrogen Fertilizer Use, $1988-1995 \ldots \ldots \ldots \ldots \ldots \ldots \ldots \ldots \ldots .42$

30. U.S. Nitrous Oxide Emissions from Industrial Processes, $1988-1995 \ldots \ldots \ldots \ldots \ldots \ldots \ldots \ldots \ldots$

31. Estimated 1994 Sales and Emissions of CFCs and Other Greenhouse Gases . . . . . . . . . . 53

32. Estimated U.S. Emissions of Halocarbons and Miscellaneous Greenhouse Gases, 1988-1995 ........ 54

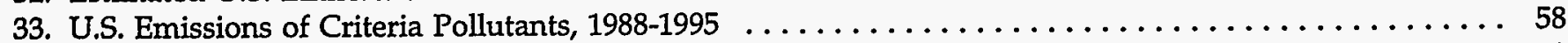

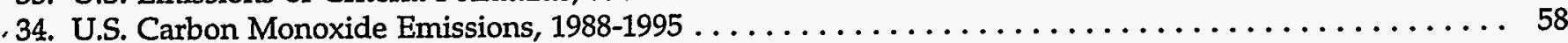

35. U.S. Nitrogen Oxide Emissions, $1988-1995 \ldots \ldots \ldots \ldots \ldots \ldots \ldots \ldots \ldots \ldots \ldots \ldots \ldots \ldots \ldots \ldots$

36. U.S. Emissions of Nonmethane Volatile Organic Compounds, $1988-1995 \ldots \ldots \ldots \ldots \ldots \ldots \ldots \ldots$. . . . 60

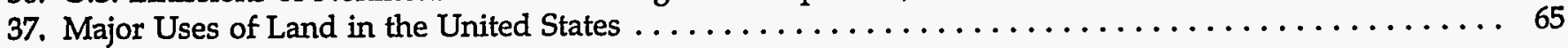




\section{Tables (Continued)}

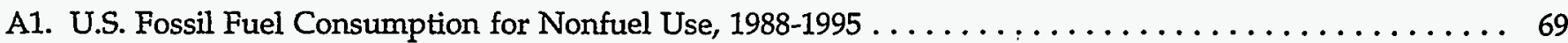

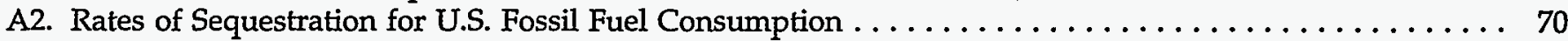

A3. Energy Consumption in U.S. Territories and International Bunkers, $1988-1995 \ldots \ldots \ldots \ldots \ldots \ldots \ldots 71$

A4. U.S. Natural Gas Consumption and Balancing Item, $1988-1995 \ldots \ldots \ldots \ldots \ldots \ldots \ldots \ldots \ldots \ldots$

A5. Production Data for Industrial Sources of Carbon Dioxide, 1984-1995 . . . . . . . . . . . . . . . . 74

A6. Activity Data for Methane Emissions from Oil and Gas Production, Processing, and Distribution,

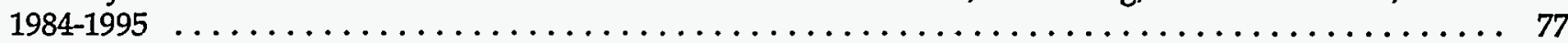

A7. Methane Emissions Factors for Oil and Gas Production, Processing, and Distribution . . . . . . . . . 78

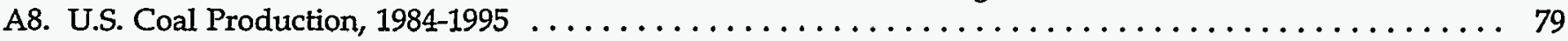

A9. EMCON Methane Generation Model Parameters $\ldots \ldots \ldots \ldots \ldots \ldots \ldots \ldots \ldots \ldots \ldots \ldots \ldots \ldots . \ldots 3$

A10. U.S. Solid Waste Landfilled, $1984-1995 \ldots \ldots \ldots \ldots \ldots \ldots \ldots \ldots \ldots \ldots \ldots \ldots \ldots \ldots \ldots \ldots . \ldots \ldots$

A11. Average Pre-Slaughter Live Weights for U.S. Cattle and Calves, 1984-1995 . . . . . . . . . . . . . . 85

A12. Factors Used To Estimate Methane and Nitrous Oxide Emissions from Burning of Crop Residues . . . . 88

A13. Methane Emissions Factors for Industrial Processes $\ldots \ldots \ldots \ldots \ldots \ldots \ldots \ldots \ldots \ldots \ldots \ldots \ldots$

B1. Carbon Emissions Coefficients at Full Combustion, $1985-1995 \ldots \ldots \ldots \ldots \ldots \ldots \ldots \ldots \ldots \ldots \ldots \ldots . \ldots 8$

B2. Changes in Motor Gasoline Density, $1988-1995 \ldots \ldots \ldots \ldots \ldots \ldots \ldots \ldots \ldots \ldots \ldots \ldots \ldots \ldots$

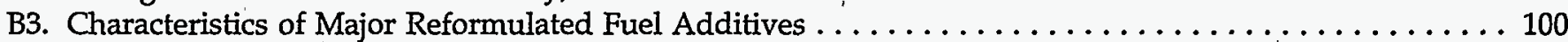

B4. Consumption-Weighted Emissions Coefficients for Jet Fuel, 1988-1995 . . . . . . . . . . . . . . . 101

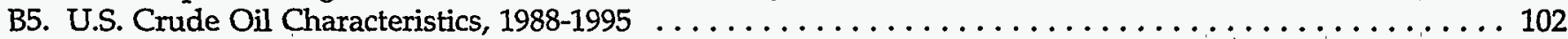

B6. Consumption Shares for Liquid Petroleum Gases by Energy Content, 1988-1995 . . . . . . . . . . . . 102

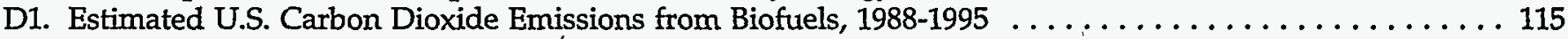

D2. Estimated Carbon Emissions from U.S. Military Operations Abroad, 1988-1995 . . . . . . . . . . . 116

D3. Estimated U.S. Carbon Dioxide Emissions from Natural Gas Plants, 1988-1995 . . . . . . . . . . . 117

\section{Figures}

ES1. Difference in U.S. Emissions of Greenhouse Gases, 1990 vs. $1994 \ldots \ldots \ldots \ldots \ldots \ldots \ldots \ldots \ldots \ldots$. . . . . . .

ES2. Estimated U.S. Emissions of Halocarbons and Related Compounds, $1980-1995$. . . . . . . . . . . . xiii

ES3. Estimated U.S. Emissions of Criteria Pollutants, $1980-1994 \ldots \ldots \ldots \ldots \ldots \ldots \ldots \ldots \ldots \ldots$ xiv

1. Energy-Related Carbon Emissions by Region, $1970-1994 \ldots \ldots \ldots \ldots \ldots \ldots \ldots \ldots \ldots \ldots \ldots$. . . . . . 9

2. Indices of U.S. Gross Domestic Product, Population, Energy Consumption, and

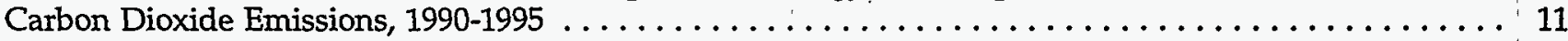

3. Annual Change in U.S. Carbon Dioxide Emissions, $1990-1995 \ldots \ldots \ldots \ldots \ldots \ldots \ldots \ldots \ldots \ldots \ldots \ldots$

4. Carbon Dioxide Emissions from Electric and Non-electric Sources by Energy End-Use Sector, 1995 . . . 12

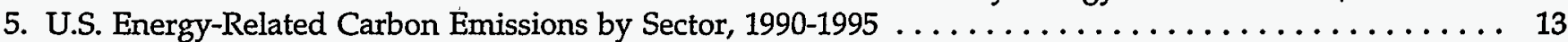

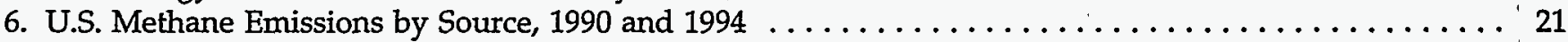

7. Difference in U.S. Methane Emissions by Source, 1990 vs. $1994 \ldots \ldots \ldots \ldots \ldots \ldots \ldots \ldots \ldots \ldots \ldots . \ldots 22$

8. U.S. Solid Waste Generated and Landfilled, $1988-1994 \ldots \ldots \ldots \ldots \ldots \ldots \ldots \ldots \ldots \ldots \ldots \ldots \ldots$

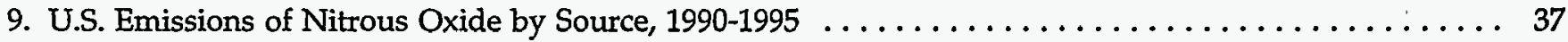

10. Difference in U.S. Nitrous Oxide Emissions by Source, 1990 vs. $1995 \ldots \ldots \ldots \ldots \ldots \ldots \ldots \ldots \ldots$. . . . . 38

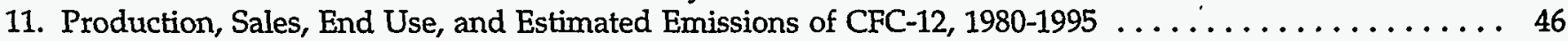

12. Forest Land in the United States, $1620,1850,1920$, and $1992 \ldots \ldots \ldots \ldots \ldots \ldots \ldots \ldots \ldots \ldots \ldots \ldots$ 


\section{Executive Summary}

This is the fourth Energy Information Administration (EIA) annual report on U.S. emissions of greenhouse gases. This report presents estimates of U.S. anthropogenic (human-caused) emissions of carbon dioxide, methane, nitrous oxide, and several other greenhouse gases for 1988 through 1994. Estimates of 1995 carbon dioxide, nitrous oxide, and halocarbon emissions are also provided, although complete 1995 estimates for methane are not yet available (Table ES1).

Emissions of carbon dioxide increased by 1.9 percent from 1993 to 1994 and by an additional 0.8 percent from 1994 to 1995. Most carbon dioxide emissions are caused by the burning of fossil fuels for energy consumption, which is strongly related to economic growth, energy prices, and weather. The U.S. economy grew rapidly in 1994 and slowed in 1995.
Estimated emissions of methane increased slightly in 1994, as a result of a rise in emissions from energy and agricultural sources.

Estimated nitrous oxide emissions increased by 1.8 percent in 1995, primarily due to increased use of nitrogen fertilizers and higher output of chemicals linked to nitrous oxide emissions.

Estimated emissions of hydrofluorocarbons (HFCs) and perfluorocarbons (PFCs), which are known to contribute to global warming, increased by nearly 11 percent in 1995, primarily as a result of increasing substitution for chlorofluorocarbons (CFCs).

With the exception of methane, the historical emissions estimates presented in this report are only slightly revised from those in last year's report (see the box on page $x$, "What's New in This Report").

Table ES1. Estimated U.S. Emissions of Greenhouse Gases by Gas, 1988-1995 (Million Metric Tons of Gas)

\begin{tabular}{|c|c|c|c|c|c|c|c|c|}
\hline Gas & 1988 & 1989 & 1990 & 1991 & 1992 & 1993 & 1994 & P1995 \\
\hline Carbon Dioxide .......... & $5,040.4$ & $5,075.6$ & $5,030.6$ & $4,982.2$ & $5,058.2$ & $5,151.1$ & $5,248.6$ & $5,288.5$ \\
\hline Methane $\ldots \ldots \ldots \ldots$ & 30.8 & 30.9 & 31.3 & 31.4 & 31.5 & 30.5 & 31.0 & NA \\
\hline Nitrous Oxide $\ldots \ldots \ldots \ldots$ & 0.4 & 0.4 & 0.4 & 0.5 & 0.5 & 0.5 & 0.5 & 0.5 \\
\hline \multicolumn{9}{|l|}{ Halocarbons and Minor Gases } \\
\hline CFC-11, CFC-12, CFC-113 . . & 0.3 & 0.3 & 0.2 & 0.2 & 0.2 & 0.2 & 0.1 & 0.1 \\
\hline HCFC-22 $\ldots \ldots \ldots \ldots \ldots$ & 0.1 & 0.1 & 0.1 & 0.1 & 0.1 & 0.1 & 0.1 & 0.1 \\
\hline HFCs and PFCs & * & * & * & * & * & * & * & * \\
\hline \multicolumn{9}{|l|}{ Criteria Pollutants } \\
\hline Carbon Monoxide ........ & 105.0 & 93.5 & 91.2 & 88.3 & 85.3 & 85.3 & 88.9 & NA \\
\hline Nitrogen Oxides ......... & 21.4 & 21.1 & 20.9 & 20.6 & 20.7 & 21.1 & 21.4 & NA \\
\hline Nonmethane VOCs . . . . . . . . & 23.3 & 21.7 & 21.4 & 20.7 & 20.3 & 20.5 & 21.0 & NA \\
\hline
\end{tabular}

"Less than 50,000 tons of gas. Estimated hydrofluorocarbon and perfluorocarbon emissions combined totaled 0.008 million metric tons in 1987, rising to 0.027 million metric tons in 1995.

$P=$ preliminary data. $N A=$ not available.

Note: Data in this table are revised from the data contained in the previous EIA report, Emissions of Greenhouse Gases in the United States 1987-1994, DOE/EIA-0573(87-94) (Washington, DC, October 1995).

Sources: Carbon dioxide, methane, nitrous oxide emissions: EIA estimates described in Chapters 2, 3, and 4 of this report. Halocarbons and minor gases: 1990 and 1994 estimates from the U.S. Environmental Protection Agency, Inventory of U.S. Greenhouse Gas Emissions and Sinks, 1990-1994, EPA-230-R-96-006 (Washington, DC, November 1995), pp. 46-50. Other years: EIA estimates described in Chapter 5 of this report. Criteria pollutants: U.S. Environmental Protection Agency, Office of Air Quality Planning and Standards, National Air Pollutant Emission Trends, 1900-1994, EPA-454/R-95-011 (Research Triangle Park, NC, October 1995), Tables A-1-A-3, pp. A-2-A-16. 


\section{What's New in This Report}

New report format. There is a new overview capsule at the beginning of each chapter, so that current trends can be easily identified. Detailed statistical tables follow at the end of each chapter. Technical sections regarding emissions sources and estimation methods have been moved to Appendix $\mathrm{A}$ for reference.

Updated global warming potentials. This year, the Intergovernmental Panel on Climate Change (IPCC) further revised its estimates of the relative radiative forcing effects of various greenhouse gases (global warming potentials, or GWPs). The revisions, mostly minor, have been incorporated in this report. The IPCC has also released revised net GWPs for certain chlorofluorocarbons and other ozone-depleting substances to reflect their offsetting global warming and cooling effects. The new net GWPs are also noted in the report.

Reformulated gasoline incorporated into the 1995 emission coefficient for motor gasoline. The Clean Air Act Amendments of 1990 mandated the use of reformulated gasoline in heavily polluted areas during the winter months beginning in 1995. Reformulated gasoline mixtures reduce aromatic content, limiting hydrocarbon emissions. The compounds typically used as additives in reformulated gasoline, MTBE, ETBE, and TAME, contain an oxygen atom in their molecules. As a result they have carbon contents ranging from 68.2 to 70.5 percent, well below the 85 to 88 percent found in standard motor gasoline. These additives represent about 12 to 13 percent of reformulated gasoline, as compared with 1 to 6 percent of standard gasoline. Thus, reformulated gasoline has a carbon emissions coefficient approximately 1 percent smaller than that of standard gasoline. In 1995, reformulated blends represented just under 25 percent of U.S. gasoline consumption. After weighting for consumption, the emissions coefficient for motor gasoline was reduced by about 0.3 percent compared to what it would have been in the absence of reformulated gasoline.

Revised historical estimates for methane emissions from oil and gas production. A recently completed study jointly funded and managed by the U.S. Environmental Protection Agency (EPA) and the Gas
Research Institute (GRI) indicates that methane emissions from the U.S. natural gas industry are substantially higher than previously estimated. This study includes a more complete inventory of the equipment components used by the natural gas industry as well as a larger and more representative sample of equipment emissions performance than was available previously. The new emissions factors were used in conjunction with industry activity data to create a revised time series of emissions estimates. The revised emissions factors raise emissions estimates for methane from oil and gas production by more than 3 million metric tons annually.

Revised methods for estimating methane emissions from the solid waste of domesticated animals. In order to capture recent changes in methods of handling animal waste in six States (Arizona, Florida, Nevada, North Carolina, North Dakota, and Texas), estimates of methane emissions from the solid waste of domesticated animals were calculated separately for these six States, and the results were added to a single estimate developed for the remainder of the country. The new method raises annual emissions estimates by just under 100,000 metric tons.

New estimates of methane emissions from domestic and commercial wastewater treatment. Estimates of this minor source of methane have been added to this year's report, raising estimated methane emissions by just over 0.15 million metric tons.

New carbon sequestration estimates. This report contains revised estimates of carbon sequestration by U.S. forests, incorporating the potential of carbon sequestered in forest soils. This revision extends the upper bound of the estimate by 127 million metric tons of carbon.

New maps of the historical extent of forest land in the United States. Maps presented in Chapter 7 of this report show the extent of forest land in 1620, 1850, 1920 and 1992, to allow for rapid visual evaluation of the substantial changes in forest cover since colonial times.

Revised energy data. Updated energy data resulted in slightly higher estimates of emissions for the years before 1995. 
In Table ES2, the emissions of each gas are weighted by its global warming potential (GWP), which is taken as a measure of radiative forcing. ${ }^{1}$ This concept, developed by the Intergovernmental Panel on Climate Change (IPCC), provides a measure of the comparative impacts of different greenhouse gases on global warming, with the effect of carbon dioxide being equal to 1 . The GWPs for other greenhouse gases are considerably higher (see discussion in Chapter 1). Overall, GWP-weighted emissions rose by 3.9 percent between 1990 and 1994 .

Table ES2 excludes several radiatively important gases, including the criteria pollutants carbon monoxide, nitrogen oxides, and particulates, as well as CFCs and hydrochlorofluorocarbons (HCFCs). These gases have ambiguous effects on climate, which are difficult to quantify. In addition, CFCs and HCFCs are specifically excluded from coverage under the international climate treaty, the Framework Convention on Climate Change (see Chapters 1, 5, and 6 for discussion related to the effects and emissions of these gases).

In Table ES1, carbon dioxide emissions are shown at full molecular weight. In Table ES2 they are shown in carbon equivalent units (see "Units for Measuring Greenhouse Gases" on page xii). While carbon dioxide accounts for 85 percent of U.S. GWP-weighted emissions, the growth of emissions since 1990 has been unevenly distributed. In particular, emissions of hydrofluorocarbons (HFCs) have grown rapidly from negligible levels in 1990, and they account for almost 7 percent of the total increase in emissions since 1990 (Figure ES1).
Figure ES1. Difference in U.S. Emissions of Greenhouse Gases, 1990 vs. 1994

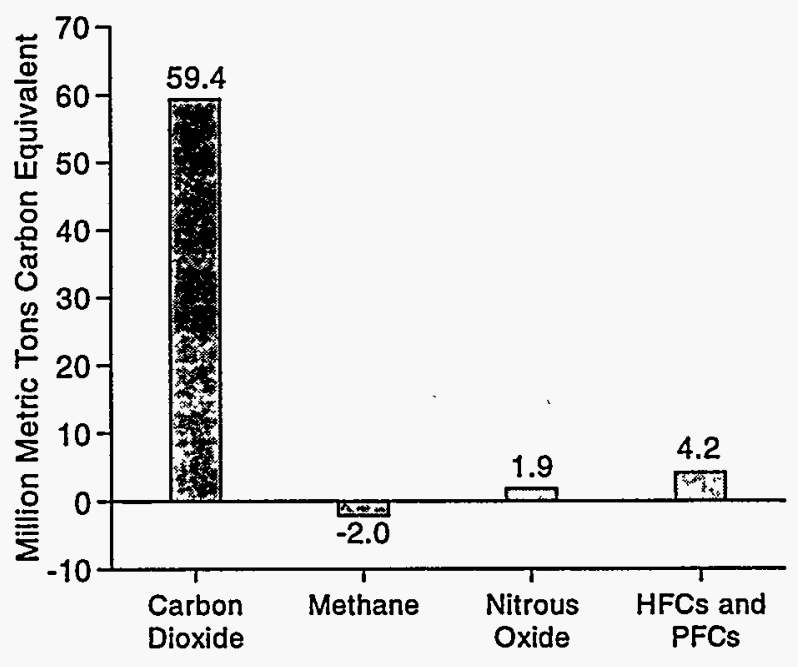

Source: ElA estimates documented in this report.

\section{Carbon Dioxide}

Some 98.5 percent of U.S. anthropogenic carbon dioxide emissions are caused by the combustion of fossil fuels. The causes of changing carbon dioxide.emissions can be found in energy consumption trends and changes in the composition of fossil fuels burned to provide energy services. During the late 1980s, with fluctuating hydroelectric power generation, the completion of nuclear power plants commissioned in the early 1970s, and increased natural gas use, the upward trend in U.S.

Table ES2. U.S. Emissions of Greenhouse Gases, Based on Global Warming Potential, 1988-1995 (Million Metric Tons of Carbon or. Carbon Equivalent)

\begin{tabular}{|c|c|c|c|c|c|c|c|c|}
\hline Gas & 1988 & 1989 & 1990 & 1991 & 1992 & 1993 & 1994 & P1995 \\
\hline Carbon Dioxide . & 1,375 & 1,384 & 1,372 & 1,359 & 1,380 & 1,405 & 1,431 & 1,442 \\
\hline Methane ........... & 177 & 177 & 179 & 180 & 180 & 174 & 178 & NA \\
\hline Nitrous Oxide .......... & 36 & 38 & 38 & 38 & 38 & 39 & 40 & 39 \\
\hline HFCs and PFCs & 19 & 20 & 19 & 19 & 21 & 20 & 23 & 25 \\
\hline Total $\ldots \ldots \ldots \ldots \ldots \ldots$ & 1,606 & 1,619 & 1,608 & 1,596 & 1,619 & 1,638 & 1,672 & NA \\
\hline
\end{tabular}

$P=$ preliminary data. $N A=$ not available.

Note: Data in this table are revised from the data contained in the previous EIA report, Emissions of Greenhouse Gases in the United States 1987-1994, DOE/EIA-0573(87-94) (Washington, DC, October 1995).

Sources: ElA estimates documented in this report and in Appendix $A$.

'Intergovernmental Panel on Climate Change, Climate Change 1995: The Science of Climate Change (Cambridge, UK: Cambridge University Press, 1996). 


\section{Units for Measuring Greenhouse Gases}

In this report, the EIA has elected to report information in forms that are most likely to be intuitively familiar to users of the document. Therefore, energy and industrial data are reported in their native units (usually international units). Oil production is reported in thousand barrels per day, and energy production and sales in (higher heating value) British thermal units (Btu).

Emissions data are reported in metric units. We have attempted to bridge the gap between users of metric units and international units by using the familiar "million metric tons" common in European industry instead of the "gigagrams" favored by the scientific community.

Emissions of most greenhouse gases are reported here in terms of the full molecular weight of the gas (as in Table ES1). In Table ES2, however, and subsequently throughout the report, carbon dioxide is measured in carbon units, defined as the weight of the carbon content of carbon dioxide (i.e., just the " $\mathrm{C}$ " in $\mathrm{CO}_{2}$ ). Carbon dioxide units at full molecular weight can be converted into carbon units by dividing by $44 / 12$, or 3.67. This approach has been adopted for two reasons:

- Carbon dioxide is most commonly measured in carbon units in the scientific community. Scientists argue that not all carbon from combustion is, in fact, emitted in the form of carbon dioxide. Be- cause combustion is never perfect, some portion of the emissions consists of carbon monoxide, methane, other volatile organic compounds, and particulates. These other gases (particularly carbon monoxide) eventually decay into carbon dioxide, but it is not strictly accurate to talk about "tons of carbon dioxide" emitted.

- Carbon units are more convenient for comparisons with data on fuel consumption and carbon sequestration. Since most fossil fuels are 75 to 90 percent carbon by weight, it is easy and convenient to compare the weight of carbon emissions (in carbon units) with the' weight of the fuel burned. Similarly, carbon sequestration in forests and soils is always measured in tons of carbon, and the use of carbon units makes it simple to compare sequestration with emissions.

While carbon dioxide emissions can be measured in tons of carbon, emissions of other gases (such as methane) can also be measured in "carbon dioxide equivalent" units by multiplying their emissions (in metric tons) by their global warming potentials. For comparability, carbon dioxide equivalent units can be converted to "carbon equivalent" by multiplying by $12 / 44$ (as in Table ES2). This method provides a measure of the relative effects of various gases on climate.' emissions of carbon dioxide slowed markedly, despite rising energy consumption. In 1990 and 1991, with the onset of economic recession and rising oil prices, both energy consumption and carbon emissions declined. However, the past 4 years have seen economic recovery, falling oil prices, and rising energy consumption, resulting in higher levels of carbon dioxide emissions. Emissions rose by 1.9 percent in 1994 and by a further 0.8 percent in 1995, and they are now some 5.1 percent (70 million metric tons of carbon) higher than in 1990.

\section{Methane}

U.S. anthropogenic methane emissions have three principal sources: production and transportation of coal, natural gas, and oil; anaerobic decomposition of municipal waste in landfills; and raising livestock. Smaller sources include combustion of fossil fuels, rice cultivation, and industrial processes. Methane emissions estimates are more uncertain than those for carbon dioxide.
Methane emissions rose during the late 1980s. The principal cause of this, trend appears to have been increasing production from a group of underground coal mines with very high rates of methane emissions. Meanwhile, emissions from municipal landfills appear to have been stable, because growth in the volume of solid waste generated was offset by a growing volume of waste burned for energy recovery and by increased recovery of methane at landfill sites.

In the 1990s, 'two factors have tended to reduce estimated methane emissions:

- Underground coal mine production has been declining in the 1990s. A strike by the United Mine Workers of America in 1993 drastically reduced coal production from a number of underground mines known to be very gassy. After the strike, overall coal production rebounded, but production in the gassiest coal mining regions of the United States continued to decline. 
- Further increases in the proliferation of recycling and "waste-to-energy" projects have reduced the apparent volume of trash being put into landfills. In combination with increased methane recovery from landfills, this trend has reduced estimated methane emissions from this source.

These factors reduced U.S. methane emissions by 0.3 million metric tons (on a GWP-weighted basis, about 2 million tons of carbon equivalent) in 1994 from their 1990 levels.

\section{Nitrous Oxide}

Nitrous oxide emissions estimates are more uncertain than estimates of methane emissions. The principal sources are believed to be "excess" emissions from agricultural soils associated with fertilizer use, industrial process emissions, and emissions from combustion of fossil fuels. Nitrous oxide emissions, estimated at 0.45 million metric tons in 1990 , grew by 3.0 percent to 0.46 million metric tons in 1995 . The main sources of growth were increased use of nitrogen fertilizers and greater industrial process emissions. However, the uncertainty of the estimation methods makes it difficult to be confident of apparent trends.

\section{Halocarbons and Related Compounds}

Halocarbons and related compounds include chlorofluorocarbons (CFCs), hydrochlorofluorocarbons (HCFCs), hydrofluorocarbons (HFCs), perfluorocarbons (PFCs), and other compounds that act as greenhouse gases. Halocarbons have many uses, but the bulk of emissions come from their use as refrigerants in cooling equipment, as solvents, or as blowing agents, or from fugitive emissions from industrial processes.

CFCs are currently being phased out because they damage the stratospheric ozone layer. The warming effects of CFCs and HCFCs are offset to some extent because they also destroy ozone, which is a potent greenhouse gas. Compounds that contain no chlorine (such as HFCs and PFCs) do not affect ozone, and their effects on climate are therefore easier to measure.

Figure ES2 illustrates emissions trends for CFCs and CFC substitutes for which sufficient information is available to estimate time series. At present, available data suggest that emissions of CFCs-about 0.2 million metric tons in 1990-are declining. Estimated HCFC emissions (almost entirely composed of HCFC-22, a popular refrigerant for home air conditioners) have

\section{Figure ES2. Estimated U.S. Emissions of Halocarbons and Related Compounds, 1980-1995}

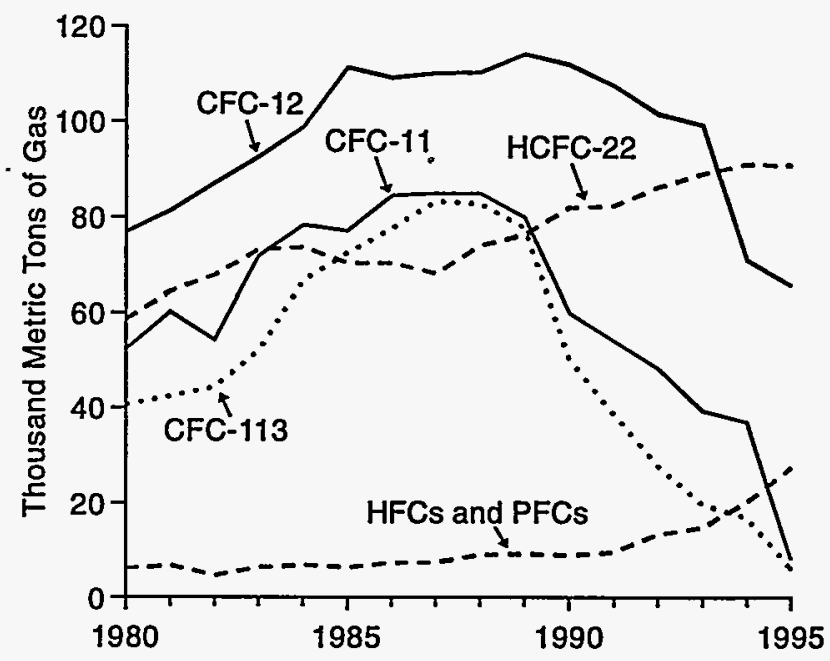

Source: ElA estimates presented in Chapter 5 of this report.

been largely stable since 1993 . There is little information about emissions of "new" HCFCs, such as HCFC-141b and HCFC-142b, which are CFC substitutes. HFC emissions were very low-perhaps 0.006 million metric tons-in 1990. Emissions of HFC-23, a byproduct of HCFC-22 production, have also been roughly stable since 1993. Emissions of the CFC substitutes HFC-134a and HFC-152 have risen substantially in the past 2 years, from a base total of less than 0.001 million metric tons in 1990. HFC-134a became the standard automobile air conditioner refrigerant in 1994, and emissions will grow rapidly as CFCs are replaced throughout the automobile fleet. HFC-152 consumption is growing rapidly, but it has a relatively low global warming potential of 140 .

The principal quantifiable source of PFCs is as a fugitive emission from aluminum smelting. Primary aluminum production declined in the mid-1990s, reducing estimated emissions.

\section{Criteria Pollutants}

Criteria pollutants (carbon monoxide, nitrogen oxides, and nonmethane volatile organic compounds) are reactive gases, which usually decay quickly in the atmosphere. They are not necessarily greenhouse gases in themselves, but they can promote atmospheric chemical reactions that create tropospheric ozone, which is a potent greenhouse gas. Because the precise ozonecreating effect of these gases varies with local atmospheric conditions, it is not possible to compute their effects directly. As they are precursors to urban 
"smog," their emissions are regulated under the Clean Air Act. The principal source of emissions of criteria pollutants is the combustion of fossil fuels, particularly in motor vehicles.

According to estimates from the U.S. Environmental Protection Agency (EPA), national-level emissions of carbon monoxide have been declining since the late 1970s (Figure ES3). Emissions of nonmethane volatile organic compounds and nitrogen oxides have been essentially unchanged in recent years.

Figure ES3. Estimated U.S. Emissions of Criteria Pollutants, 1980-1994

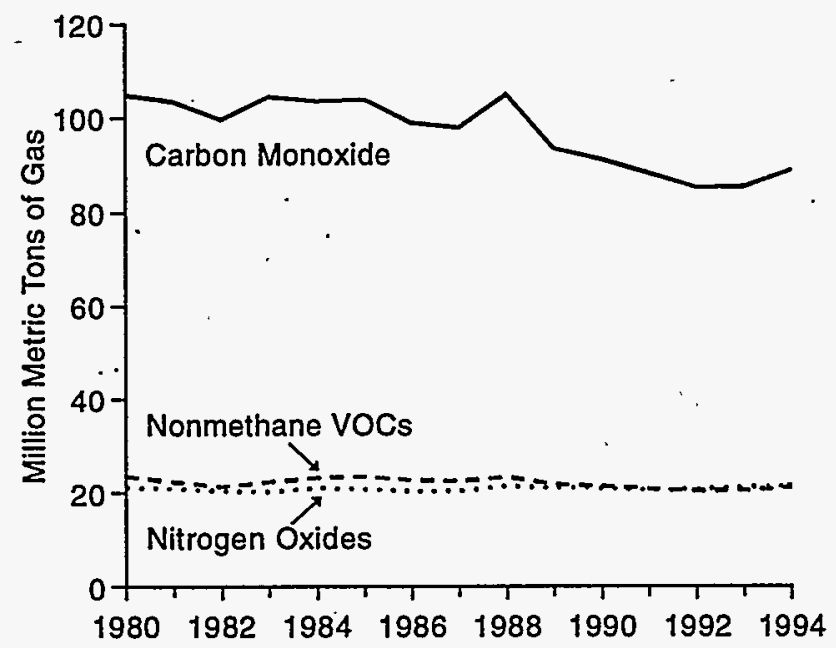

Source: U.S. Environmental Protection Agency, Office of Air Quality Planning and Standards, National Air Pollutant Emission Trends, 1900-1994, EPA-454/R-95-027 (Research Triangle Park, NC, October 1995), Tables A-1-A-11, pp. A-2-A-16.

\section{Land Use Issues}

Changes in land use can also have large, though difficult to quaritify, effects on atmospheric concentrations. In the United States, the expansion of forest land and the growth of existing forests are responsible for removing large amounts of carbon from the atmosphere. Several studies of carbon sequestration in U.S. forests suggest that in the late 1980s and early 1990s, some 111 to 238 million metric tons of carbon was sequestered annually, equivalent to about 8 to 17 percent of U.S. anthropogenic carbon emissions. ${ }^{2}$ However, considerable uncertainty is associated with this estimateparticularly with the amount of carbon sequestered in forest soils.

The IPCC recommends including emissions and sequestration from land use changes in national inventories, and the U.S. "National Communication" for the Framework Convention follows this practice. ${ }^{3}$ However, the EIA has elected not to include carbon sequestration from forestry in its "total" estimate of U.S. emissions, for the following reasons:

- There is insufficient information to determine the extent, if any, of year-to-year changes in anthropogenic sequestration of carbon. Changes in national sequestration rates can be estimated only at 5year intervals. The current estimate is an annual average for the period 1987-1992; new data will become available in 1998, covering the 1992-1997 period.

- The magnitude of the sequestration estimate is subject to considerable uncertainty on several counts. The largest source of uncertainty is the amount of carbon sequestered annually in forest soils.

${ }^{2}$ R.A. Birdsey and L.S. Heath, "Carbon Changes in U.S. Forests," in L.A. Joyce (ed.), Productivity of America's Forests and Climate Change (Fort Collins, CO: USDA Forest Service, General Technical Report RM-GTR-271; 1995).

${ }^{3}$ U.S. Environmental Protection Agency, Inventory of U.S. Greenhouse Gas Emissions and Sinks: 1990-1993, EPA-230-R-94-014 (Washington, DC, September'1994), p. ES-7. 


\section{U.S. Emissions of Greenhouse Gases in Perspective}

\section{About this Report}

The Energy Information Administration (EIA) is required by the Energy Policy Act of 1992 to prepare a report on aggregate U.S. national emissions of greenhouse gases for the period 1987-1990, with annual updates thereafter. This report is the fourth annual update, covering national emissions over the period 1988-1994, with preliminary estimates of emissions for 1995.

Chapter 1 of this report briefly recapitulates some background information about global climate change and the greenhouse effect and discusses important recent developments in global climate change activities. Chapters 2 through 6 cover emissions of carbon dioxide, methane, nitrous oxide, halocarbons, and criteria pollutants, respectively. Chapter 7 describes potential sequestration and emissions of greenhouse gases as a result of land use changes.

Five appendixes are included with this report. Appen$\operatorname{dix} A$ provides a detailed discussion of emissions sources, estimation methods, and data requirements and sources. Appendix $B$ describes the derivation of the carbon emissions coefficients used for the inventory. Appendix $C$ describes uncertainties in the emissions estimates. Appendix $D$ describes known emissions sources omitted from the main report due to definitions of "anthropogenic" or due to excessive uncertainty. Appendix E provides some convenient conversion factors.

\section{The Greenhouse Effect and Global Climate Change}

The Earth is warmed by light from the Sun. Over time, the amount of energy transmitted to the Earth's surface is equal to the amount of energy re-radiated back into space in the form of infrared radiation, and the temperature of the Earth's surface stays roughly constant. However, the temperature of the Earth is strongly influenced by the existence, density, and composition of the
Earth's atmosphere. Many gases in the Earth's atmosphere absorb infrared radiation re-radiating from the Earth's surface, trapping heat in the lower atmosphere. Without the natural greenhouse effect, it is likely that the average temperature of the Earth's surface would be on the order of $-19^{\circ}$ Celsius, rather than the $+15^{\circ}$ Celsius actually observed. The gases that help trap the Sun's heat close to the Earth's surface are referred to as "greenhouse gases." All greenhouse gases absorb infrared radiation (heat) at particular sets of wavelengths.

The main greenhouse gases are water vapor $\left(\mathrm{H}_{2} \mathrm{O}\right)$, carbon dioxide $\left(\mathrm{CO}_{2}\right)$, methane $\left(\mathrm{CH}_{4}\right)$, nitrous oxide $\left(\mathrm{N}_{2} \mathrm{O}\right)$, and a host of engineered chemicals such as chlorofluorocarbons (CFCs). Most greenhouse gases occur naturally. Water vapor is by far the most common, with an atmospheric concentration of nearly 1 percent, compared with less than 0.04 percent for carbon dioxide. Concentrations of other greenhouse gases are a fraction of that for carbon dioxide (Table 1).

It was recognized in the early 1960s that concentrations of carbon dioxide in the Earth's atmosphere were increasing every year. Subsequently, it was discovered that atmospheric concentrations of methane, nitrous oxide, and many engineered chemicals were also rising. Current concentrations of greenhouse gases keep the Earth at its present temperature. Would increasing concentrations of greenhouse gases make the Earth get even warmer?

In computer-based simulation models, rising concentrations of greenhouse gases nearly always produce an increase in the average temperature of the Earth. Rising temperatures may, in turn, produce changes in weather and in the level of the oceans that might prove disruptive to current patterns of land use and human settlement, as well as to existing ecosystems. To date, it has proven difficult to detect hard evidence of actual temperature changes, in part, because normal temporal and spatial variations in temperature are far larger than the predicted change in the global average temperature. Even when temperature changes are identified, it is not possible to be certain whether they are random fluctuations that will reverse themselves or are the beginning

\footnotetext{
${ }^{1}$ Intergovernmental Panel on Climate Change, Climate Change 1995: The Science of Climate Change (Cambridge, UK: Cambridge University Press, 1996), p. 57. See also http://www.unep.ch/ipcc/ipcc95.html.
} 
Table 1. Global Atmospheric Concentrations of Greenhouse Gases

\begin{tabular}{|c|c|c|c|c|c|}
\hline \multirow[b]{2}{*}{ Item } & Carbon Dioxide & Methane & Nitrous Oxide & CFC-11 & CFC-12 \\
\hline & \multicolumn{3}{|c|}{ (parts per million) } & \multicolumn{2}{|c|}{ (parts, per trillion) } \\
\hline Preindustrial Atmospheric Concentration ... & 278 & 0.700 & 0.275 & 0 & 0 \\
\hline 1992 Atmospheric Concentration ....... & 356 & 1.714 & 0.311 & 268 & 503 \\
\hline Average Annual Change ... & 1.6 & 0.008 & 0.0008 & 0 & 7 \\
\hline Average Change (Percent per Year) $\ldots$. & 0.4 & 0.6 & 0.25 & 0 & 1.4 \\
\hline Atmospheric Lifetime (Years) $\ldots \ldots \ldots \ldots$. . & $50-200$ & 12 & 120 & 50 & 102 \\
\hline
\end{tabular}

Source: Intergovernmental Panel on Climate Change, Climate Change 1995: The Science of Climate Change (Cambridge, UK: Cambridge University Press, 1996), p. 92.

of a trend. The possible effects of rising temperatures on weather patterns are even more uncertain.

The most recent report of the Intergovernmental Panel on Climate Change (IPCC), an international assemblage of scientists commissioned by the United Nations to study this matter, concluded that:

Our ability to quantify the human influence on global climate is currently limited because the expected signal is still emerging from the noise of natural variability, and because there are uncertainties in key factors. These include the magnitudes and patterns of long-term variability and the time-evolving pattern of forcing by, and response to, changes in concentrations of greenhouse gases and aerosols, and land surface changes. Nevertheless, the balance of evidence suggests that there is a discernable human influence on climate. ${ }^{2}$

While both the existence and consequences of humaninduced climate change remain uncertain, the threat of climate change has put in train an array of efforts by governments both in the United States and abroad to find some mechanism for limiting the risk of climate change and ameliorating possible consequences. To date, efforts have focused on identifying levels and sources of emissions of greenhouse gases and on possible mechanisms for reducing emissions or increasing absorption of greenhouse gases.

\section{Global Sources of Greenhouse Gases}

Most greenhouse gases have substantial natural sources in addition to human-made sources, and there are powerful natural mechanisms for removing them from the atmosphere. However, the continuing growth in atmospheric concentrations establishes that, for each of the major greenhouse gases, more gas is being emitted than is being absorbed each year: that is, the natural absorption mechanisms are lagging behind. Table 2 illustrates the relationship between anthropogenic and natural emissions and absorption of the principal greenhouse gases.

Water Vapor. Water vapor, as noted above, is the most common greenhouse gas present in the atmosphere. It is emitted into the atmosphere in enormous volumes, through natural evaporation from oceans, lakes, and soils, and returned to Earth in the form of rain and snow. Water vapor is so plentiful in the atmosphere already that additional emissions are unlikely to absorb any significant amount of infrared radiation. It is also likely that the amount of water vapor held in the atmosphere is generally in equilibrium, and that increasing emissions of water vapor would not increase atmospheric concentrations. ${ }^{3}$ According to currently available information, anthropogenic water vapor emissions at the Earth's surface are unlikely to be an important element in either causing or ameliorating climate change.

Carbon Dioxide. Carbon is a common element on the planet, and immense quantities can be found in the atmosphere, in soils, in carbonate rocks, and dissolved in ocean water. All life on Earth participates in the "carbon cycle," by which carbon dioxide $\left(\mathrm{CO}_{2}\right)$ is extracted from the air by plants and decomposed into carbon and oxygen, with the carbon being incorporated into plant biomass and the oxygen released to the atmosphere. Plant biomass, in turn, ultimately decays

\footnotetext{
${ }^{2}$ Intergovernmental Panel on Climate Change, Climate Change 1995: The Science of Climate Change (Cambridge, UK: Cambridge University Press, 1996), p. 5.

${ }^{3}$ Note, however, that changing air temperature from other causes will change the equilibrium amount of water vapor contained in the atmosphere, and this may be a "feedback" effect acting to accelerate or damp global climate change.
} 
Table 2. Global Natural and Anthropogenic Sources and Absorption of Greenhouse Gases

\begin{tabular}{|c|c|c|c|c|}
\hline \multirow[b]{2}{*}{ Gas } & \multicolumn{2}{|c|}{ Sources } & \multirow[b]{2}{*}{ Absorption } & \multirow{2}{*}{$\begin{array}{c}\text { Annual Increase in Gas } \\
\text { in the Atmosphere }\end{array}$} \\
\hline & Natural & Human-Made & & \\
\hline Carbon Dioxide (Million Metric Tons of Carbon) . & 150,000 & 7,100 & 154,000 & $3,100-3,500$ \\
\hline Methane (Million Metric Tons of Gas) & $110-210$ & $300-450$ & $460-660$ & $35-40$ \\
\hline Nitrous Oxide (Million Metric Tons of Gas) & $6-12$ & $4-8$ & $13-20$ & $3-5$ \\
\hline
\end{tabular}

Source: Summarized from ranges appearing in Intergovernmental Panel on Climate Change, Climate Change 1995: The Science of Climate Change (Cambridge, UK: Cambridge University Press, 1996), pp. 17-19.

(oxidizes), releasing carbon dioxide back into the atmosphere, or storing organic carbon in soil or rock. There are vast exchanges of carbon dioxide between the ocean and the atmosphere, with the ocean absorbing carbon from the atmosphere and plant life in the ocean absorbing carbon from water, dying, and spreading organic carbon on the sea bottom, where it is eventually incorporated into carbonate rocks such as limestone.

Records from Antarctic ice cores indicate that the carbon cycle has been in a state of imbalance for the past 200 years, with emissions of carbon dioxide to the atmosphere exceeding absorption. Consequently, carbon dioxide concentrations in the atmosphere have been steadily rising.

The most important natural sources of carbon dioxide are releases from the oceans (90 billion metric tons per year), aerobic decay of vegetation ( 30 billion metric tons), and plant and animal respiration (30 billion metric tons). ${ }^{4}$ Known anthropogenic sources account for 7 billion metric tons of carbon per year. The principal anthropogenic source is the combustion of fossil fuels, which accounts for about three-quarters of total anthropogenic emissions of carbon worldwide. Natural processes-primarily, uptake by the ocean and photosynthesis-absorb substantially all of the naturally produced carbon dioxide and some of the anthropogenic carbon dioxide, leading to an annual net increase in carbon dioxide in the atmosphere of 3.1 to 3.5 billion metric tons. ${ }^{5}$

Methane. Methane $\left(\mathrm{CH}_{4}\right)$ is also a common compound. The methane cycle is understood less well than is the carbon cycle. Methane is released primarily by anaerobic decay of vegetation, by the digestive tracts of termites in the tropics, and by several other lesser sources. The principal anthropogenic sources are leakages from the production of fossil fuels, human- promoted anaerobic decay in landfills, and the digestive tracts of domestic animals. The main sources of absorption are thought to be decomposition (into carbon dioxide) in the atmosphere and decomposition by bacteria in soil. Known and unknown sources of methane are estimated to total about 600 million metric tons annually; known sinks (i.e., absorption by natural processes) total about 560 million metric tons. The annual increase in methane concentrations in the atmosphere accounts for the difference of 35 to 40 million metric tons.

Nitrous Oxide. The sources and absorption of nitrous oxide $\left(\mathrm{N}_{2} \mathrm{O}\right)$ are much more speculative than those for other greenhouse gases. The principal sources are thought to be bacterial breakdown of nitrogen compounds in soils, particularly forest soils, and fluxes from ocean upwellings. The primary human-made sources are enhancement of natural processes through application of nitrogen fertilizers, combustion of fuels, and certain industrial processes. The most important sink is thought to be decomposition in the stratosphere. Worldwide estimated known sources of nitrous oxide total 13 to 20 million metric tons annually, and known sinks total 10 to 17 million metric tons. The annual increase in concentrations in the atmosphere is thought to total about 4 million metric tons.

Halocarbons and Other Chemicals. In the twentieth century, human ingenuity has produced an array of "engineered" chemicals not normally found in nature, whose special characteristics render them particularly useful. Some engineered chemicals are also greenhouse gases. The best known class of greenhouse chemicals are the chlorofluorocarbons (CFCs), particularly CFC-12, often known by its trade name, "freon-12." CFCs have many desirable features: they are relatively simple to manufacture, inert, nontoxic, and nonflammable. Because CFCs are chemically stable, once emitted, they

\footnotetext{
'Intergovernmental Panel on Climate Change, Climate Change 1995: The Science of Climate Change (Cambridge, UK: Cambridge University Press, 1996), p. 77.

${ }^{5}$ One metric ton equals 1.102 short tons.
} 
remain in the atmosphere for hundreds or thousands of years. Because they are not found in nature, these molecules absorb reflected infrared radiation at wavelengths that would otherwise be largely unabsorbed, and they are potent greenhouse gases, with a direct radiative forcing effect hundreds or thousands of times greater, gram-per-gram, than that of carbon dioxide.

Because of their long atmospheric lives, a portion of the CFCs emitted into the atmosphere eventually find their way into the stratosphere, where they can be destroyed by sunlight. This reaction, however, releases free chlorine atoms into the stratosphere, and the free chlorine atoms tend to destroy stratospheric ozone, which protects the surface of the Earth from certain wavelengths of potentially damaging solar ultraviolet radiation (ultraviolet radiation, for example, is one cause of human and animal skin cancers). The destruction of stratospheric ozone, notwithstanding its potential damage to living organisms, exerts a net cooling effect on the surface of the planet, making the net effects of CFCs on radiative forcing ambiguous.

The threat posed by CFCs to the ozone layer has caused the United States and many other countries to commit themselves to phasing out the production of CFCs and their chemical cousins, hydrochlorofluorocarbons (HCFCs) pursuant to an international treaty, the 1987 Montreal Protocol. As use of CFCs has declined, many related chemicals have emerged as alternatives, including HCFCs and hydrofluorocarbons (HFCs). HCFCs are similar to CFCs, but they are more reactive and consequently have shorter atmospheric lives, with less effect on the ozone layer and smaller direct global warming effects. HCFCs are also being phased out, but over a much longer time scale.

HFCs have no chlorine, and consequently have no effect on the ozone layer, but they have potentially powerful direct effects on climate. HFCs were rare before 1990, but in 1994 HFC-134a was adopted as the standard motor vehicle air conditioning refrigerant in virtually all new cars made in America. Consequently, HFC emissions are now rising rapidly, though from a negligible base.

Beyond the halocarbons (CFCs, HFCs, HCFCs, and PFCs) there are a range of engineered chemicals, produced in relatively small quantities, which also have direct radiative forcing effects. These include the perfluorocarbons $\left(\mathrm{CF}_{4}, \mathrm{C}_{2} \mathrm{~F}_{6}\right.$, and $\left.\mathrm{C}_{3} \mathrm{~F}_{8}\right)$ emitted as by- products of aluminum smelting; some industrial solvents such as carbon tetrachloride, methyl chloroform, methylene chloride; and other more obscure chemicals such as sulfur hexafluoride $\left(\mathrm{SF}_{6}\right)$ and, possibly, other chemicals not yet identified. Some of these compounds are regulated in the United States as ozone depleters, or for toxicity, or both.

Criteria Pollutants. There are three gases, emitted primarily as byproducts of combustion (both of fossil fuels and of biomass), which have an indirect effect on global warming: carbon monoxide, nitrogen oxides, and nonmethane volatile organic compounds (NMVOCs). These compounds, regulated in the United Sates pursuant to the Clean Air Act, are often referred to (along with particulates, lead, and sulfur dioxide) as "criteria pollutants." The criteria pollutants are reactive compounds, and they tend to remain in the atmosphere for only hours or days. The sequence of reactions that removes them from the atmosphere, however, tends to promote the formation of ozone $\left(\mathrm{O}_{3}\right)$, a reactive and unstable molecular form of oxygen. While ozone in the stratosphere protects life, on Earth from ultraviolet radiation, ozone at ground level at high concentrations causes respiratory distress in people and animals and also is, itself, a potent (though short-lived) greenhouse gas. $^{6}$

It has not proven possible to make a general determination of the contribution of criteria pollutants to global warming. The reactions that produce ozone are strongly affected by the relative concentrations of various pollutants, the ambient temperature, and local weather. Emissions of criteria pollutants can create very high, though localized, ozone concentrations under favorable conditions (for example, a warm, sunny day combined with still air and low humidity) and negligible concentrations under unfavorable conditions. The criteria pollutants are included in this report for completeness.

Aerosols. Finally, there is a class of gases which probably exert a net cooling effect on the climate. These compounds create a cooling effect by creating tiny solid particles (aerosols) in the atmosphere, which, in turn, act as nuclei for collections of water droplets and stimulate cloud formation. The clouds, in turn, reflect sunlight back into space, cooling the planet. The most important such gas is sulfur dioxide $\left(\mathrm{SO}_{2}\right)$, which is largely emitted as a byproduct from the combustion of sulfur-containing fossil fuels, particularly coal. Sulfur dioxide reacts in the air to form sulfate compounds that

\footnotetext{
${ }^{6}$ The Environmental Protection Agency has set a National Ambient Air Quality Standard for acceptable atmospheric concentrations of ozone at 0.12 parts per million. The standard was set on the basis that concentrations of this magnitude could cause respiratory distress in vulnerable individuals, such as asthmatics. Higher concentrations (above 0.3 parts per million) would cause respiratory distress for most individuals.
} 
are effective in promoting cloud formation. Sulfur dioxide emissions are regulated in the United States under the Clean Air Act and have declined considerably in recent years. Particulate emissions are also likely to exert a net cooling effect.

\section{Relative Forcing Effects of Various Gases}

Some greenhouse gases are more potent in affecting global temperatures than are others. As a result, comparable increases in the concentrations of different greenhouse gases can have vastly different heattrapping effects. Among those identified, carbon dioxide is among the least effective as a greenhouse gas. Other compounds, on a gram-per-gram basis, appear to have much greater effects. ${ }^{7}$

It would be useful to determine the precise relative effectiveness of various greenhouse gases in affecting the Earth's climate. This information would help policymakers know whether it would be more effective to concentrate effort on reducing the very small emissions of powerful greenhouse gases, such as HFC-134a, or whether they should bend their efforts to controlling the very large emissions of relatively ineffective gases, such as carbon dioxide.

There has been extensive study of the relative effectiveness of various greenhouse gases in trapping the Earth's heat. This research has led to the development of the concept of a "global warming potential," or GWP. The GWP is intended to illustrate the relative impacts on global warming of various gases, compared with carbon dioxide. Over the past few years, the IPCC has conducted an extensive research program aimed at summarizing the effects of various greenhouse gases through a set of GWPs. The results of that work were released last year in an IPCC report, Climate Change $1994^{8}$ and updated this year in Climate Change 1995..$^{\circ}$

The IPCC's work has established that the effects of various gases on global warming are too complex to permit them to be easily summarized as a single number. The complexity takes several forms:

- Each gas absorbs radiation in a particular set of wavelengths or "window," in the spectrum. In some cases, where concentrations of the gas are low and no other gases block radiation in the same window, small emissions of the gas will have a disproportionate absorptive effect. However, if concentrations of the gas rise over time, a larger and larger portion of the total light passing through the "window" will already have been captured, and the marginal effects of additional emissions will decline. Therefore, the effect of an additional unit of emission of a gas that is relatively plentiful in the atmosphere, such as water vapor or carbon dioxide, tends to be less than that of a rare gas, such as sulfur hexafluoride. This "diminishing return" effect implies that increasing the concentration of a particular gas reduces the impact of adding additional quantities of that gas. Thus, the relative impacts of various gases will change as their relative concentrations in the atmosphere change.

- Various natural processes cause many greenhouse gases to decompose into other gases, or to be absorbed into the ocean or ground. These processes can be summarized in terms of the "atmospheric lifetime" of a particular gas, or the period of time it would take for natural processes to remove a unit of emissions from the atmosphere. Some gases, such as CFCs, have very long atmospheric lifetimes, in the hundreds of years, while others, such as carbon monoxide, have lives measured in hours or days. Methane, which decays into carbon dioxide over a period of a few years, has a much larger short-run effect on global warming than does an equivalent amount of carbon dioxide. However, over longer and longer periods-from 10 years to 100 years to 500 years, for example- the differences between the GWPs of methane and carbon dioxide become less significant.

- Many gases are chemically active, and they may react in the atmosphere in ways that promote or hinder the formation of other greenhouse gases. For example, nitrogen oxides and carbon monoxide combine to promote the formation of ozone, which is a potent greenhouse gas, while CFCs tend to destroy atmospheric ozone, thus promoting global cooling. These indirect effects have sometimes proven impossible to summarize in terms of global warming potentials. Indirect effects also imply that changes in relative concentrations of various greenhouse gases would tend to change their relative effects.

\footnotetext{
7Intergovernmental Panel on Climate Change, Climate Change 1995: The Science of Climate Change (Cambridge, UK: Cambridge University Press, 1996), p. 22.

${ }^{8}$ Intergovernmental Panel on Climate Change, Climate Change 1994: Radiative Forcing of Climate Change (Cambridge, UK: Cambridge University Press, 1995).

${ }^{9}$ Intergovernmental Panel on Climate Change, Climate Change 1995: The Science of Climate Change (Cambridge, UK: Cambridge University Press, 1996).
} 
Despite such complexity, the scientific community is working to develop GWP approximations. Table 3 summarizes the consensus results of the most recent studies by scientists working on behalf of the IPCC, showing estimates of atmospheric lifetimes and global warming potentials across various time scales.

The Intergovernmental Panel on Climate Change has also devoted effort to studies of indirect and interaction effects of various gases-particularly the indirect effects of chlorofluorocarbons (CFCs) and hydrochlorofluorocarbons (HCFCs) on the ozone layer-compared with their direct radiative forcing effects. The IPCC presented GWP estimates for the first time this year that quantified the direct and indirect effects of certain CFCs and HCFCs (Table 4). Certain chemicals (halon-1301 and carbon tetrachloride, for example) are now believed to exert a net cooling influence-i.e., to have a negative global warming potential. All of the net global warming potentials for CFCs and HCFCs are considerably lower than their direct GWPs. The authors of the IPCC report believe that the relative magnitudes of the net GWPs are fairly reliable, but that the absolute levels have an uncertainty of \pm 50 percent. ${ }^{10}$

\section{Global Climate Change Policy Developments}

Rising concentrations of carbon dioxide in the atmosphere were first detected in the late 1950s. Observations of atmospheric concentrations of methane, nitrous oxide, and other gases began in the late 1970s. However, concern about the effects of rising atmospheric concentrations of greenhouse gases remained largely the province of atmospheric scientists and climatologists until the mid-1980s, when a series of international scientific workshops and conferences began to move the topic onto the agenda of United Nations specialized agencies, particularly, the World Meteorological Office.

The IPCC was established under the auspices of the United Nations in late 1988, to accumulate available scientific research on climate change and to provide scientific advice to policymakers. A series of international conferences provided impetus for an international treaty aimed at limiting the human impact on climate. In December 1990, the United Nations established the Intergovernmental Negotiating ,Committee for a Framework Convention on Climate Change

Table 3. Numerical Estimates of Global Warming Potentials Compared With Carbon Dioxide (Kilogram of Gas per Kilogram of Carbon Dioxide)

\begin{tabular}{|c|c|c|c|c|}
\hline \multirow[b]{2}{*}{ Gas } & \multirow{2}{*}{$\begin{array}{l}\text { Lifetime } \\
\text { (Years) }\end{array}$} & \multicolumn{3}{|c|}{ Direct Effect for Time Horizons of } \\
\hline & & 20 Years & 100 Years & 500 Years \\
\hline Carbon Dioxide ........... & Variable & 1 & 1 & 1 \\
\hline Methane...$\ldots \ldots \ldots \ldots$ & $12 \pm 3$ & 56 & 21 & 7 \\
\hline Nitrous Oxide $\ldots \ldots \ldots \ldots \ldots$ & 120 & 280 & 310 & 170 \\
\hline \multicolumn{5}{|l|}{ HFCs, PFCs, and Other Gases } \\
\hline HFC-23 & 264 & 9,200 & 12,100 & 9,900 \\
\hline HFC-125 & 33 & 4,800 & 3,200 & 11 \\
\hline HFC-134a $\ldots \ldots \ldots \ldots$ & 15 & 3,300 & 1,300 & 420 \\
\hline HFC-152a $\ldots \ldots \ldots \ldots \ldots$ & 2 & 460 & 140 & 42 \\
\hline HFC-227ea $\ldots \ldots \ldots \ldots$ & 37 & 4,300 & 2,900 & 950 \\
\hline Perfluoromethane..$\ldots \ldots \ldots$. & 50,000 & 4,400 & 6,500 & 10,000 \\
\hline Perfluoroethane $\ldots \ldots \ldots \ldots$ & 10,000 & 6,200 & 9,200 & 14,000 \\
\hline Sulfur Hexafluoride $\ldots \ldots \ldots$ & 3,200 & 16,300 & 23,900 & 34,900 \\
\hline
\end{tabular}

Note: The typical uncertainty for global warming potentials is estimated by the Intergovernmental Panel on Climate Change at \pm 35 percent.

Source: Intergovernmental Panel on Climate Change, Climate Change 1995: The Science of.Climate Change (Cambridge, UK: Cambridge University Press, 1996), p. 121.

\footnotetext{
${ }^{10}$ Intergovernmental Panel on Climate Change, Climate Change 1995: The Science of Climate Change (Cambridge, UK: Cambridge University Press, 1996), p. 122.
} 
Table 4. Numerical Estimates of Global Warming Potentials, Including Indirect Effects, for Selected Chlorofluorocarbons and Hydrochlorofluorocarbons Compared With Carbon Dioxide (Kilograms of Gas per Kilogram of Carbon Dioxide)

\begin{tabular}{|c|c|c|c|c|}
\hline \multirow[b]{3}{*}{ Gas } & \multicolumn{4}{|c|}{ Magnitude of Effects } \\
\hline & \multicolumn{2}{|c|}{ 20-Year Integration } & \multicolumn{2}{|c|}{ 100-Year Integration } \\
\hline & Direct Effects & $\begin{array}{l}\text { Direct Effects and } \\
\text { Indirect Effects }\end{array}$ & Direct Effects & $\begin{array}{l}\text { Direct Effects and } \\
\text { Indirect Effects }\end{array}$ \\
\hline \multicolumn{5}{|l|}{ Chlorofluorocarbons } \\
\hline CFC-11 $\ldots \ldots \ldots \ldots \ldots$ & 4,900 & 1,200 to 2,900 & 3,800 & 540 to 2,100 \\
\hline CFC-12 $\ldots \ldots \ldots \ldots \ldots$ & 7,800 & 6,000 to 6,800 & 8,100 & 6,000 to 7,100 \\
\hline CFC-113 $\ldots \ldots \ldots \ldots \ldots$ & 4,900 & 2,800 to 3,800 & 4,800 & 2,600 to 3,600 \\
\hline \multicolumn{5}{|l|}{ HFCs, PFCs, and Other Gases } \\
\hline HCFC-22 $\ldots \ldots \ldots \ldots \ldots \ldots$ & 4,000 & 3,500 to 3,700 & 1,500 & 1,300 to 1,400 \\
\hline HCFC-123 $\ldots \ldots \ldots \ldots \ldots$ & 300 & 60 to 170 & 90 & 20 to 50 \\
\hline HCFC-124 . . . . . . . . . & 1,500 & 1,300 to 1,400 & 470 & 390 to 430 \\
\hline HCFC-141b $\ldots \ldots \ldots \ldots \ldots$ & 1,800 & 660 to 1,200 & 600 & 170 to 370 \\
\hline HCFC-142b $\ldots \ldots \ldots \ldots \ldots$ & 4,100 & 3,600 to 3,800 & 1,800 & 1,600 to 1,700 \\
\hline Halon-1301 . . . . . . . & 6,100 & $-14,100$ to $-97,600$ & 5,400 & $-14,100$ to $-84,000$ \\
\hline Carbon Tetrachloride ........ & 1,900 & -500 to $-2,600$ & 1,400 & -650 to $-2,400$ \\
\hline Methyl Chloroform .......... & 300 & -400 to $-1,000$ & 100 & -130 to -320 \\
\hline
\end{tabular}

Note: The typical uncertainty for net global warming potentials (including direct and indirect effects) is estimated by the Intergovernmental Panel on Climate Change at \pm 50 percent.

Source: Intergovernmental Panel on Climate Change, Climate Change 1995: The Science of Climate Change (Cambridge, UK: Cambridge University Press, 1996), p. 119.

(generally called the INC). Beginning in 1991, the INC hosted a series of negotiating sessions that culminated in the signing, by more than 160 countries, including the United States, of the Framework Convention on Climate Change in Rio de Janeiro on May 4, 1992."11 The objective of the Framework Convention ("the Rio Treaty") was to:

... achieve ... stabilization of the greenhouse gas concentrations in the atmosphere at a level that would prevent dangerous anthropogenic interference with the climate system. ${ }^{12}$

The Framework Convention, as it emerged from the negotiations, was based on the concept of voluntary commitments by signatories to take steps to implement the objectives of the. Convention. These steps, as described in the treaty, include national commitments to prepare and submit for review national action plans and periodic national emissions inventories. Developed country signatories (including the United States), referred to in the language of the convention as "Annexe I Countries," made additional commitments:

Each of these Parties shall communicate... detailed information on its policies and measures... Ito limit emissions of greenhouse gases] . . . with the aim of returning individually or jointly to their 1990 levels these anthropogenic emissions of carbon dioxide and other greenhouse gases not controlled by the Montreal Protocol. This information will be reviewed by the Conference of the Parties, at its first session and periodically thereafter.... ${ }^{13}$

\footnotetext{
${ }^{11}$ This discussion draws on D. Bodanzky, "Prologue to the Climate Convention," in I. Minter and J.A. Leonard (eds.), Negotiating Climate Change: The Inside Story of the Rio Convention (Cambridge, UK: Cambridge University Press, 1994), pp. 49-66.

${ }^{12}$ United Nations, "Report of the Intergovernmental Negotiating Committee for a Framework on Convention on Climate Change on the Work of the Second Part of Its Fifth Session, Held at New York from 30 April to 9 May 1992," UN Document A/AC.237/18, Part II (May 15, 1992). See also http://www.unep.ch/unfccc/fca6.html.

${ }^{13}$ United Nations, "Report of the Intergovernmental Negotiating Committee for a Framework on Convention on Climate Change on the Work of the Second Part of Its Fifth Session, Held at New York from 30 April to 9 May 1992," UN Document A/AC.237/18, Part II (May 15, 1992).
} 
The greenhouses gases "controlled by the Montreal Protocol" are CFCs and HCFCs, which are explicitly defined as being outside the scope of the Framework Convention.

Pursuant to the requirement to "communicate . . . detailed information" on policies and measures, the outgoing Bush Administration prepared a draft national action plan in December 1992.14 On April 21, 1993 (Earth Day), President Clinton committed the United States to stabilizing its emissions of greenhouse gases at 1990 levels by the year 2000. The methods proposed by the Government to achieve this objective were described in the President's Climate Change Action Plan, published in October 1993. ${ }^{15}$ That document spells out a range of largely voluntary programs intended to achieve the stabilization objective. More detail-oriented readers may wish to consult the Technical Supplement to the Plan, published in early 1994, which spells out the assumptions underlying the Plan in greater detail. ${ }^{16}$

The Conference of the Parties is required to meet annually to discuss the implementation of the Framework Convention, and to review countries' voluntary commitments to limit their emissions. The first such meeting was held in Berlin in April 1995. By 1995, the signatories' focus had shifted from meeting emissions targets for the year 2000 to the question of what steps would be taken beyond 2000. At Berlin, the Conference of the Parties agreed on "the Berlin Mandate," which was an agreement "to begin a process to enable it [the Conference of the Parties] to take appropriate action for the period beyond 2000 ... through the adoption of a protocol or another legal instrument $t^{\prime 17}$-in other words, to negotiate a successor agreement to the Framework Convention for the next decade. However, the Berlin Mandate accelerated the "two track" approach to emissions limitation already in evidence in the Framework Convention. There were to be no new commitments for developing countries: rather they were to be encouraged to implement their commitments under the Framework Convention. Meanwhile, the Annexe I countries would move ahead with negotiating additional measures.

The past year. has been spent in considering the possible forms the successor agreement might take. The most recent report of the IPCC has been cited by member governments, including the U.S. Government, as evidence that motivates further measures to limit emissions of greenhouse gases. The second Conference of the Parties was held in Geneva in July 1996. At that meeting, the Conference issued a "Ministerial Declaration" to the effect that the Governments present would:

Instruct their representatives to accelerate negotiations on the text of a legally-binding protocol or other legal instrument to be completed in due time for adoption at the Third Session of the Conference of the Parties [i.e., by July 1997]. The outcome should fully encompass the remit of the Berlin Mandate, in particular,

- policies and measures including, as appropriate ...

- quantified legally-binding objectives for emission limitations and significant overall reductions within specified timeframes, such as 2005, 2010, 2020 , with respect to their anthropogenic emissions .... ${ }^{18}$

Thus, the governments of the United States and Western Europe have agreed to negotiate, within the next year, a treaty with quantified emissions targets over the next two decades. The target levels, and the measures to be proposed to meet the targets, remain to be seen.

\section{U.S. Emissions in an International Perspective}

The United States is the world's largest single emitter of carbon dioxide, accounting for about 23 percent of energy-related carbon emissions worldwide. The U.S. share of methane and nitrous oxide emissions, although uncertain, is likely to be much lower than its share of carbon dioxide emissions, as the principal sources of methane and nitrous oxide emissions are more common outside than within the United States. In the case of halocarbons and other gases, the U.S. share is likely to be considerably larger than 23 percent, because the use of cooling and refrigeration equipment is probably much more pervasive in the United States than elsewhere in the world.

\footnotetext{
${ }^{14}$ U.S. Department of State, National Action Plan for Global Climate Change, Publication 10026 (Washington, DC, December 1992).

${ }^{15}$ President William J. Clinton, The Climate Change Action Plan (Washington, DC, October 1993), p. i. See also http://gcrio.gcrio.org/ USCCAP/toc.html.

${ }^{16}$ U.S. Department of Energy, The Climate Change Action Plan: Technical Supplement, DOE/PO-0011 (Washington DC, March 1994).

${ }^{17}$ United Nations Framework Convention on Climate Change, Report of the Conference of the Parties on Its First Session, Held at Berlin from 28 March to 7 April 1995 (Addendum), Part 2: "Action Taken by the Conference of the Parties at Its First Session," FCCC/CP/1995/7/ Add.1 (6 June 1995), p. 5. See also http://www.unep.ch/unfccc/fca3e.html.

${ }^{18}$ United Nations Framework Convention on Climate Change, Review of the Implementation of the Convention and of Decisions of the First Session of the Conference of the Parties: Ministerial Declaration, FCCC/CP/1996/L.17 (18 July 1996), p. 3.
} 
In recent decades, the carbon dioxide emissions of North America and Western Europe have been growing relatively slowly (Figure 1). The worldwide growth in energy-related carbon dioxide emissions has come from rapid growth in the developing world and in the former centrally planned economies. The most striking development in the 1990s has been the rapid reduction in energy consumption (and hence carbon emissions) in the countries of the former Soviet Union and Eastern Europe, where emissions dropped by more than 20 percent between 1989 and 1992 and have continued to decline through 1994. Emissions reductions in former communist countries have been sufficient to stabilize world energy-related carbon dioxide emissions at 1990 levels through 1994, despite continuing rapid growth in the developing world, stable emissions in Western Europe, and slow growth in the United States.

This year, the EIA released a projection of worldwide carbon emissions estimates in its International Energy Outlook $1996 .{ }^{19}$ That projection suggests that the postcommunist decline in energy consumption is a one-time phenomenon, and that energy consumption in these countries will "bottom out" in the next few years and begin to rise again. Since the EIA also expects rapid growth in energy consumption in the developing world to continue, the prospect is for continued growth in worldwide carbon emissions.

\section{Figure 1. Energy-Related Carbon Emissions by Region, 1970-1994}

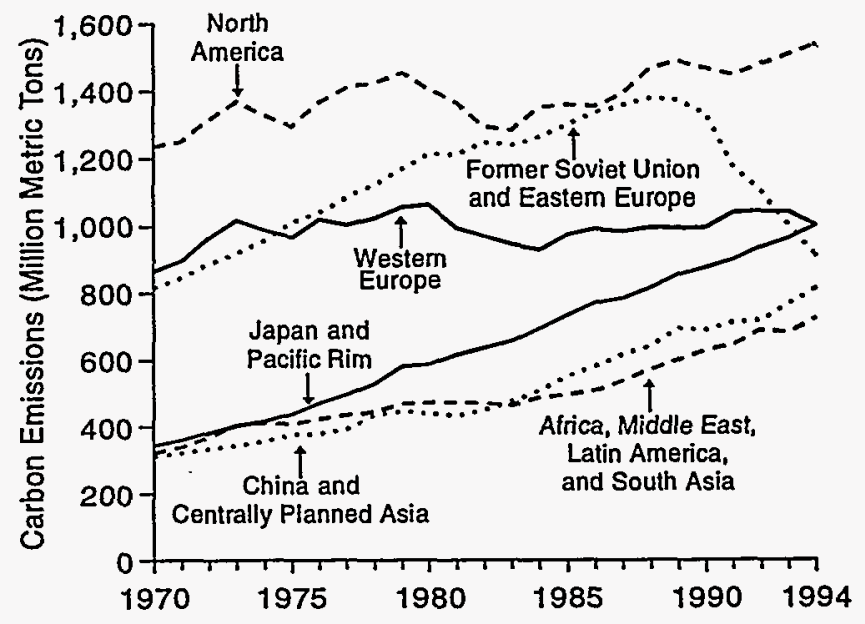

Source: Estimated by the Energy Information Administration, based on world energy consumption as reported in Energy Information Administration, International Energy Annual, DOE/EIA-0219 (Washington, DC, various years). The data set is available at http://www.eia.doe.gov.

\footnotetext{
${ }^{19}$ Energy Information Administration, International Energy Outlook 1996, DOE/EIA-0484(96) (Washington, DC, January 1996). See also http://www.eia.doe.gov/oiaf/ieo96/front.html.
} 
$\mid$ 


\section{Carbon Dioxide Emissions}

\section{Overview}

\begin{tabular}{|c|c|c|}
\hline \multicolumn{3}{|c|}{$\begin{array}{l}\text { U.S. Anthropogenic Carbon Dioxide } \\
\text { Emissions, 1990-1995 }\end{array}$} \\
\hline & $\begin{array}{l}\text { Carbon } \\
\text { Dioxide }\end{array}$ & $\begin{array}{l}\text { Carbon } \\
\text { Equivalent }\end{array}$ \\
\hline $\begin{array}{l}\text { Estimated } 1995 \text { Emissions } \\
\text { (Million Metric Tons) }\end{array}$ & $5,288.5$ & $1,442.3$ \\
\hline $\begin{array}{l}\text { Change Compared to } 1994 \\
\text { (Million Metric Tons) }\end{array}$ & 39.9 & 10.9 \\
\hline $\begin{array}{l}\text { Change from } 1994 \\
\text { (Percent) }\end{array}$ & 0.8 & 0.8 \\
\hline $\begin{array}{l}\text { Change Compared to } 1990 \\
\text { (Million Metric Tons) }\end{array}$ & 257.9 & 70.3 \\
\hline $\begin{array}{l}\text { Change from } 1990 \\
\text { (Percent) }\end{array}$ & 5.1 & 5.1 \\
\hline
\end{tabular}

U.S. carbon dioxide emissions are largely caused by the combustion of coal, natural gas, and petroleum. ${ }^{20} \mathrm{~A}$ fraction (less than 2 percent) comes from other sources, including the manufacture of cement and lime. Total estimated emissions increased by 0.8 percent from 1994 to about 1,442 million metric tons of carbon in 1995 (Table 5). ${ }^{21}$ Compared to 1990 emissions levels, the increase is about 70 million metric tons or 5.1 percent. ${ }^{22}$

Over the long term, carbon dioxide emissions are related to trends in economic activity and energy consumption, as well as the particulars of fuel choice. In the 1990s the growth in energy consumption lagged behind trends in the economy. For example, in 1995 the economy grew by about 2.1 percent, while energy consumption increased slightly less, by about 1.9 percent (Figure 2). Carbon dioxide emissions rose even less, by
Figure 2. Indices of U.S. Gross Domestic Product, Population, Energy Consumption, and Carbon Dioxide Emissions, 1990-1995

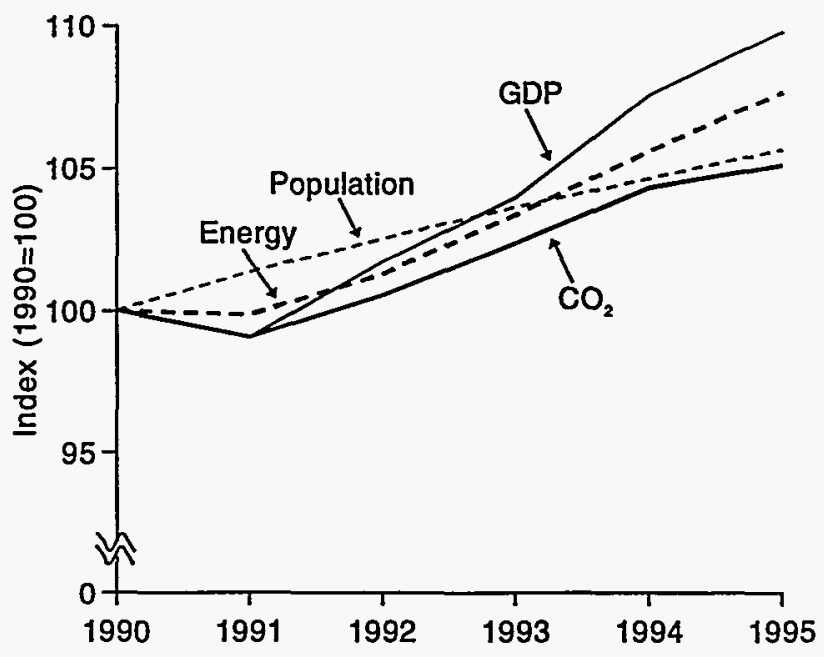

Sources: Carbon dioxide emissions are EIA estimates documented in this report. Energy consumption, gross national product (constant dollars), and population are reported in Energy Information Administration, Annual Energy Review 1995, DOE/EIA-0384(95) (Washington, DC, July 1996), pp. 5, 13 , and 367.

a modest 0.8 percent, because of increased nuclear and hydroelectric power production. Between 1994 and 1995 total energy consumption in the United States increased by 1.7 quadrillion Btu. Although low emitting nuclear power and renewable fuels ordinarily provide about 15 percent of the U.S. energy supply, gains from these sources supplied two-thirds of the increase in U.S. energy requirements for 1995, thereby moderating grow th in energy-related carbon emissions. The year-toyear increase was only about 11 million metric tons of carbon in 1995, a smaller increase than in the previous year (Figure 3).

\footnotetext{
${ }^{20}$ For a detailed discussion of emissions sources and the approach taken for estimation, see Appendixes A and B.

${ }^{21}$ Following common practice in the scientific community, this report presents estimates of carbon dioxide emissions in units of carbon. If desired, carbon units can be converted to carbon dioxide at full molecular weight by multiplying tons of carbon by 3.667 .

${ }^{22}$ Estimates of carbon dioxide emissions are much less uncertain than estimates for emissions of other greenhouse gases. Estimates of underlying fuel consumption data are believed to be reliable within plus or minus three to five percent. This is discussed extensively in Appendix C.
} 
Figure 3. Annual Change in U.S. Carbon Dioxide Emissions, 1990-1995

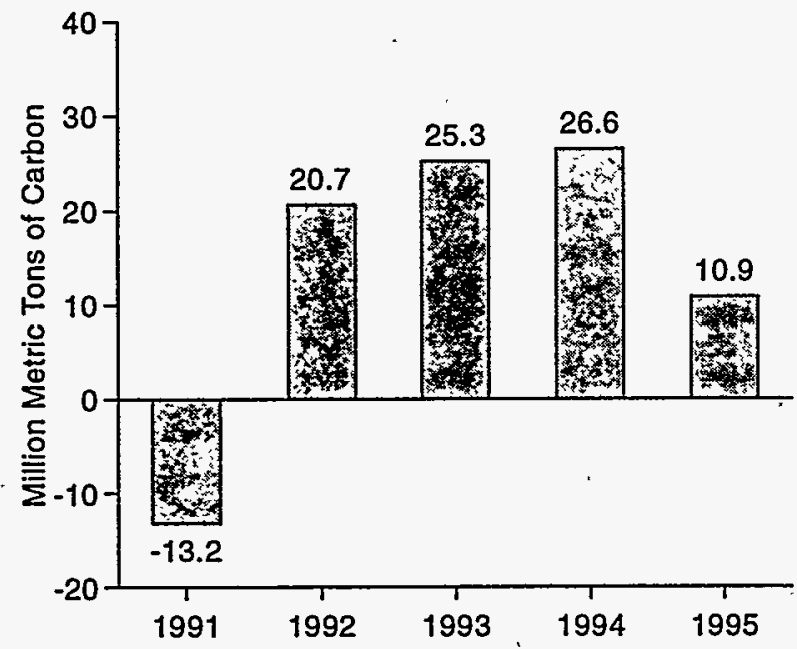

Source: Estimates presented in this chapter.

\section{Energy Consumption}

\begin{tabular}{|c|c|c|c|c|}
\hline \multicolumn{5}{|c|}{$\begin{array}{l}\text { Energy End-Use Sector Sources of } \\
\text { Carbon Dioxide Emissions, 1990-1995 }\end{array}$} \\
\hline \multirow[b]{2}{*}{ Sector } & \multicolumn{2}{|c|}{$\begin{array}{l}\text { Million Metric } \\
\text { Tons Carbon }\end{array}$} & \multicolumn{2}{|c|}{$\begin{array}{l}\text { Percent } \\
\text { Change }\end{array}$} \\
\hline & 1990 & 1995 & $\begin{array}{l}1990- \\
1995\end{array}$ & $\begin{array}{l}1994- \\
1995\end{array}$ \\
\hline Transportation & 432.1 & 457.2 & 5.8 & 1.5 \\
\hline Industrial & 452.4 & 462.9 & 2.3 & -0.1 \\
\hline Commercial & 206.7 & 218.4 & 5.6 & 2.0 \\
\hline Residential & 253.0 & 270.9 & 7.1 & 0.9 \\
\hline
\end{tabular}

Note: Electric utility emissions are distributed across sectors.

\section{Recent Trends}

EIA energy statistics partition total energy consumption into four end-use sectors: industrial, transportation, residential, and commercial. For all the sectors except transportation, a substantial portion of the energy used is consumed as electricity. In the future most of the growth in energy consumption is expected to be in the transportation sector and in the use of electricity. In this report, emissions for each sector are defined as the sum of emissions resulting from the direct burning of fuels plus emissions associated with producing electric power used in the sector. This approach makes sectoral analysis more meaningful and helps to reveal the full value of conservation when electricity is conserved. Not only is final energy saved but also the substantial amount of energy (and associated emissions) taken as "losses" in electric power generation. More than twothirds of the carbon dioxide emissions in the residential and commercial sectors are derived from electricity (Figure 4).

\section{Figure 4. Carbon Dioxide Emissions from Electric and Non-electric Sources by Energy End-Use Sector, 1995}

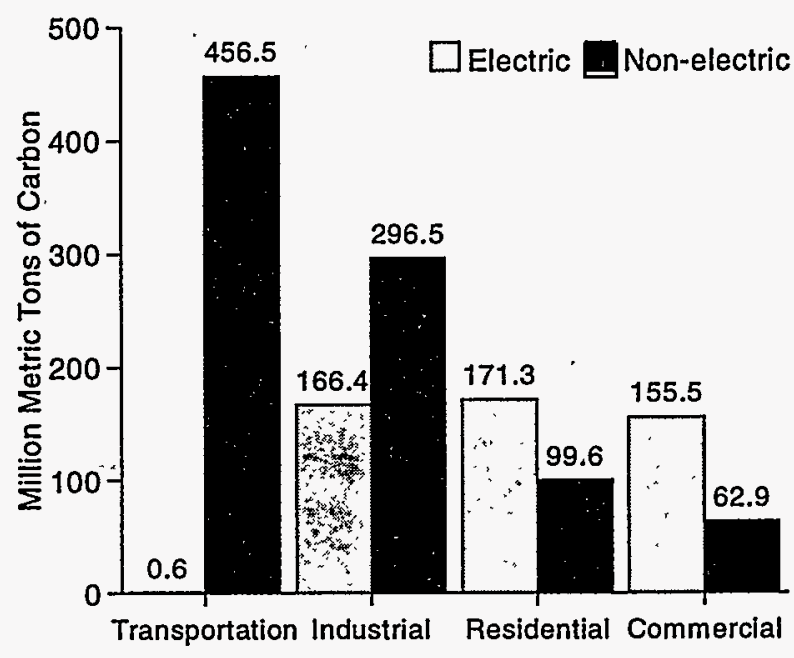

Source: Estimates presented in this chapter.

\section{Industrial}

About one-third of end-use carbon dioxide emissions are accounted for by the industrial sector (Table 6), which comprises manufacturing industries, the largest part of the sector, along with mining, construction, agriculture, fisheries, and forestry. Energy consumption is dominated by the need for heat and power; however, a large share of industrial energy use involves consumption of raw materials for petrochemical feedstocks. Natural gas and electricity consumption each account for about one-third of the energy consumed in this sector (with losses in electricity generation included).

Although some carbon in the "nonfuel" use of energy is sequestered (Table 7), emissions amounted to nearly 463 million metric tons of carbon in 1995, up 0.5 percent from the previous year (Table 8 ). Energy efficiency improvements, combined with low growth in energyintensive industries, have moderated trends in carbon dioxide emissions while total industrial output has expanded. Between 1990 and 1995, emissions for this sector increased by 10.5 million metric tons of carbon. 


\section{Transportation}

The transportation sector accounts for about one-third of U.S. carbon dioxide emissions. Growth in this sector is more rapid than in the other end-use sectors. Increases in the driving age population, low energy prices, and stable average fuel efficiency in vehicles all contribute to expanding energy consumption. Motor gasoline accounts for nearly two-thirds of transportation sector energy consumption. Together with emissions from distillate, residual, and jet fuels, total emissions were about 457 million metric tons of carbon for the transportation sector in 1995 (just under the amount emitted by the industrial sector) (Table 9). Transportation sector emissions have accounted for nearly 25 million metric tons, or nearly 40 percent, of the national increase for end-use sectors since 1990. Forecasts of U.S. energy markets imply that emissions from transportation will overtake those from the industrial sector sometime before the year 2000 (Figure 5). ${ }^{23}$

Figure 5. U.S. Energy-Related Carbon Emissions by Sector, 1990-1995

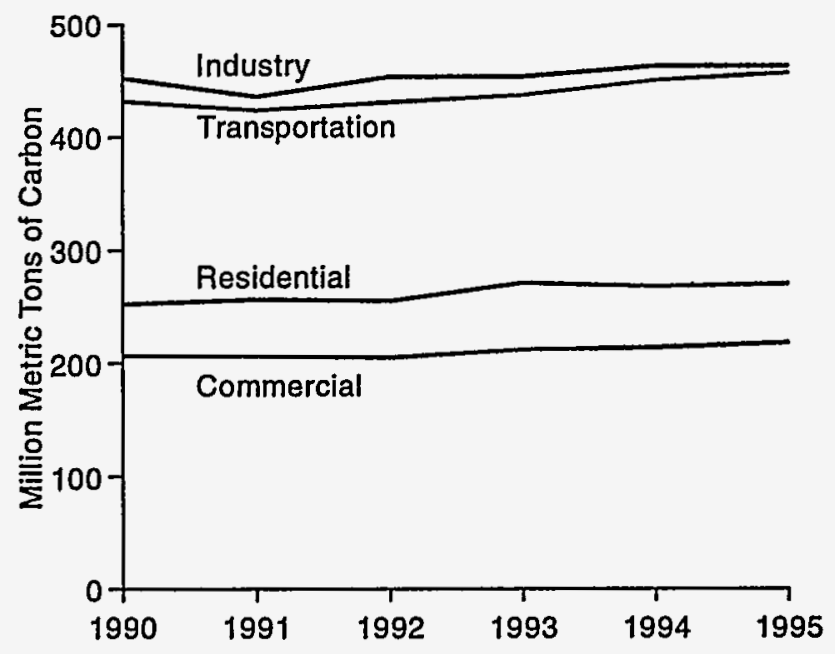

Note: Electric utility emissions are distributed across end-use consumption sectors.

Source: Estimates presented in this chapter.

\section{Residential}

Carbon dioxide emissions from this sector account for less than one-fifth of U.S. emissions (Table 6). Most of these emissions are associated with the use of natural gas and electricity for space heating and air conditioning and thus are subject to the vagaries of the weather. In 1995 residential emissions declined slightly due tomilder weather, which lowered consumption of distil- late fuels and natural gas. However, over the 5-year period from 1990, residential emissions have accounted for 18 million metric tons, or about one-third, of the increase in carbon dioxide emissions for all end-use sectors (Table 10).

\section{Commercial}

The commercial sector contributes the smallest share of carbon dioxide emissions, about 15 percent of the total. Since this sector includes all business establishments that are not engaged in transportation or in manufacturing or other types of industrial activity (agriculture, mining, or construction), most of the energy consumed is electricity and natural gas. Commercial sector carbon dioxide emissions increased by 1.6 million metric tons or 0.7 percent to 218.5 million metric tons in 1995 (Table 11). Between 1990 and 1995 the commercial sector accounted for nearly 12 million tons of the total increase in U.S. emissions.

\section{Electric Utilities}

\begin{tabular}{|c|c|c|c|c|}
\hline \multicolumn{5}{|c|}{$\begin{array}{l}\text { Electric Utility Carbon Dioxide Emissions } \\
\text { by Fuel Input, } 1990 \text { and } 1995\end{array}$} \\
\hline \multirow[b]{2}{*}{ Fuel } & \multicolumn{2}{|c|}{$\begin{array}{l}\text { Million Metric } \\
\text { Tons Carbon }\end{array}$} & \multicolumn{2}{|c|}{$\begin{array}{l}\text { Percent } \\
\text { Change }\end{array}$} \\
\hline & 1990 & 1995 & $\begin{array}{r}1990- \\
1995\end{array}$ & $\begin{array}{l}1994- \\
1995\end{array}$ \\
\hline Petroleum & 26.6 & 14.0 & -47.4 & -32.1 \\
\hline Natural Gas & 41.2 & 47.0 & 14.2 & 7.0 \\
\hline Coal & 409.0 & 432.8 & 5.8 & 0.6 \\
\hline Total & 476.9 & 493.8 & 3.6 & -0.2 \\
\hline
\end{tabular}

Although end users create the demand for electricity, the utilities make decisions about how to meet that demand, based on fuel prices and capacity availability. In 1995 demand for power increased by 2.9 percent, but utility carbon emissions declined because nuclear and conventional hydroelectric power generation met a disproportionately large share of the increased demand. Water conditions in the Pacific Northwest were better than normal in 1995, and the average capacity factor for nuclear power was up to 78 percent, following a pattern consistent with a long-term trend in improved

\footnotetext{
${ }^{23}$ Energy Information Administration, Annual Energy Outlook 1996, DOE/EIA-0383(96) (Washington, DC, January 1996). See http://www. eia,doe.gov/oiaf/aeo96/homepage.html.
} 
availability. Neither of these power sources is associated with any significant carbon dioxide emissions.

Over the longer term, the trend in electric utility emissions has been upward. Although utility efforts to improve efficiency in production and to implement demand-side management programs have kept emissions lower than they otherwise would have been, between 1990 and 1995 emissions from burning fossil fuels to meet end-use demand accounted for an increase of 17 million metric tons of carbon. ${ }^{24}$ This was primarily because of increased use of coal, the highest emitting fuel, which currently provides 55 percent of U.S. electric power (Table 12). In the future, expanded use of natural gas may slow further growth in emissions.

\section{Industrial Sources}

\begin{tabular}{|c|c|}
\hline \multicolumn{2}{|c|}{$\begin{array}{l}\text { U.S. Carbon Dioxide Emissions from } \\
\text { Industrial Sources, 1990-1995 }\end{array}$} \\
\hline $\begin{array}{l}\text { Estimated } 1995 \text { Emissions } \\
\text { (Million Metric Tons Carbon) }\end{array}$ & 21.3 \\
\hline $\begin{array}{l}\text { Change Compared to } 1994 \\
\text { (Million Metric Tons Carbon) }\end{array}$ & 0.3 \\
\hline Change from 1994 (Percent) & 1.4 \\
\hline $\begin{array}{l}\text { Change Compared to } 1990 \\
\text { (Million Metric Tons Carbon) }\end{array}$ & 2.4 \\
\hline Change from 1990 (Percent) & 12.8 \\
\hline
\end{tabular}

\section{Recent Trends}

Emissions from industrial sources account for only about 1.5 percent of total U.S. carbon dioxide emissions. This level of emissions fluctuates annually between 20 and 21 million metric tons of carbon, depending largely on the level of activity in the construction industries and production at oil and gas wells. The remaining, relatively minor, sources are limestone and dolomite consumption, soda ash manufacture and consumption, carbon dioxide manufacture, and aluminum production. Most of the change in 1995 resulted from increased cement production and manufacture of lime..$^{25}$

\section{Energy Production}

When an oil field is developed for petroleum extraction, any natural gas associated with that field may be flared if its use is not economically justifiable. This is typically the case with a remote site or when the gas is of poor quality or minimal volume. In the United States the total amount of natural gas vented or flared has increased in recent years, from about 150 billion cubic feet in 1990 to 228 billion cubic feet in 1994. The portion flared caused nearly 2 million metric tons of carbon emissions in 1995 (Table 13).

\section{Industrial Processes}

Industrial processes account for about 18 to 20 million metric tons of carbon emissions per year (Table 14). Since 1990, emissions from industrial process have increased due to an increase in emissions from cement manufacture and limestone consumption (partially offset by a decrease in emissions from aluminum manufacture). More than one-half of the emissions from industrial process are from cement manufacture. When calcium carbonate is heated (calcined) in a kiln, it is converted to lime and carbon dioxide. The lime is combined with other materials to produce clinker (an intermediate product from which cement is made), while the carbon dioxide is released to the atmosphere. In 1995, the United States manufactured an estimated 77 million metric tons of cement, or 6 percent of the world's total. In recent years, this has resulted in emissions of 9 to 10 million metric tons of carbon.

There are numerous other industrial processes in which carbonate minerals are used in ways that release carbon dioxide into the atmosphere, including the use of limestone in flue gas desulfurization and the manufacture and some uses of soda ash. Approximately 5 million metric tons of carbon per year is emitted from these sources. Carbon dioxide is also released during aluminum smelting, when carbon anodes (with the carbon ultimately derived from nonfuel use of fossil fuels) are vaporized in the presence of aluminum oxide.

\section{Adjustments to Energy Consumption}

Under the Framework Convention, parties to the agreement committed to providing information on emissions trends, using methods that would facilitate international

\footnotetext{
${ }^{24} \mathrm{As}$ reported to the EIA, electric utilities save about 1 to 2 percent of energy demand because of demand-side management programs. See Energy Information Administration, U.S. Electric Utility Demand Side Management 1994, DOE/EIA-0589(94) (Washington, DC, December 1995).

${ }^{25}$ See Energy Information Administration, Natural Gas Monthly, DOE/EIA-0130 (various issues), Table 8.
} 
comparison of emissions estimates. To support such comparisons, a generalized reporting format was adopted. The format differs slightly from that used in the preparation of U.S. national energy statistics, primarily with respect to the definition of "consumption" and the treatment of energy consumption in U.S. territories and consumption of bunker fuels for international transport. EIA's energy data for the United States cover the 50 States and the District of Columbia but not the U.S. territories. Bunker fuels (fuel consumed by ships and aircraft engaged in international trade) are subsumed in EIA's transportation sector energy consumption data. By contrast, energy data used by the International Energy Agency for the United States include U.S. territories and excludes bunker fuels. Finally, the generalized format uses a "top-down" approach to estimate "apparent energy consumption" from data on energy production and trade. For most countries around the world this is the best approach, because energy consumption is not always accurately reported. For the United States, however, the EIA provides information (used for estimates in this report) on consumption by end-use sector and fuel type for a wide array of petroleum products, coal, and natural gas.

Collectively, these differences in treatment can produce variations of several percentage points in reported energy consumption, and hence in the estimates of carbon emissions. The methodology for calculating U.S. territories' emissions and other adjustments, is described in Appendix A.

\section{U.S. Territories}

In this report, carbon dioxide emissions for the U.S. territories (Puerto Rico, Virgin Islands, Guam, American Samoa, Micronesia, and Wake Island) are included as an adjustment. Their combined energy consumption is only about 0.5 quadrillion Btu and is concentrated on petroleum products; only Puerto Rico uses coal. Together, they emitted an estimated 12 million metric tons of carbon in 1995 (Table 15).

\section{Bunker Fuels}

In this report, emissions from bunker fuels are subsumed in the estimates of carbon emissions from energy consumption. ${ }^{26}$ These emissions are also shown separately in Table 15. The estimate is based on purchases of fuel by ocean-going ships in U.S. ports and by international air carriers in U.S. airports. In 1994 bunker fuel emissions amounted to about 21 million metric tons of carbon.

\section{Unmetered Gas}

If consumption is estimated as "apparent consumption" using a top-down approach based on production plus imports minus exports plus stock change, then statistical discrepancies will be included in consumption. There are statistical discrepancies between estimated U.S. production and consumption of all fossil fuels. In the case of natural gas, it is probable (though by no means certain) that some portion of the statistical discrepancy is due to unreported natural gas consumption and stock changes. Therefore, this report includes an estimate of emissions from "unaccounted for natural gas" (which is likely to be due to unreported consumption) as an adjustment to the national emissions estimate. This item is also part of the difference between emissions estimates based on "apparent consumption" and estimates based on consumption actually reported. In recent years, the amount of carbon emissions from this source has varied from -1 to 4 million metric tons.

\footnotetext{
${ }^{26}$ "Bunker fuels" comprise fuel consumed by ships and aircraft traveling internationally. In trade and national accounts statistics, bunker fuels are treated as exports rather than domestic consumption.
} 
Table 5. U.S. Carbon Dioxide Emissions from Energy and Industry, 1988-1995 (Million Metric Tons of Carbon)

\begin{tabular}{|c|c|c|c|c|c|c|c|c|}
\hline Fuel Type or Process & 1988 & 1989 & 1990 & 1991 & 1992 & 1993 & 1994 & P1995 \\
\hline \multicolumn{9}{|l|}{ Energy Consumption } \\
\hline Petroleum & 601.6 & 601.2 & 589.4 & 569.9 & 581.3 & 583.5 & 596.5 & 594.3 \\
\hline Coal $\ldots \ldots \ldots \ldots \ldots$ & 479.2 & 479.8 & 481.5 & 475.7 & 478.5 & 494.6 & 496.6 & 498.4 \\
\hline Natural Gas & 263.1 & 274.8 & 273.4 & 279.1 & 286.5 & 297.0 & 303.4 & 316.6 \\
\hline Total Energy Consumption .. & $1,344.0$ & $1,355.8$ & $1,344.2$ & $1,324.6$ & $1,346.3$ & $1,375.0$ & $1,396.5$ & $1,409.4$ \\
\hline \multicolumn{9}{|l|}{ Adjustments to U.S. Energy } \\
\hline U.S. Territories & 8.5 & 9.4 & 9.3 & 10.9 & 9.9 & 10.7 & 12.5 & 10.7 \\
\hline Unmetered Gas & 3.7 & 0.4 & -0.4 & 4.4 & 4.3 & -1.1 & 1.4 & 0.9 \\
\hline Total Adjustments $\ldots \ldots \ldots$ & 12.2 & 9.8 & 8.9 & 15.3 & 14.2 & 9.6 & 14.0 & 11.7 \\
\hline \multicolumn{9}{|l|}{ Other Sources } \\
\hline Cement Production & 8.7 & 8.7 & 8.8 & 8.5 & 8.6 & 9.1 & 9.7 & 10.5 \\
\hline Other Industrial & 8.1 & 8.3 & 8.3 & 8.3 & 8.3 & 8.2 & 8.4 & 9.0 \\
\hline Gas Flaring & 1.7 & 1.7 & 1.8 & 2.1 & 2.1 & 2.9 & 2.9 & 1.8 \\
\hline Total Other Sources .. & 18.5 & 18.7 & 18.9 & 18.9 & 18.9 & 20.2 & 21.0 & 21.3 \\
\hline Total & $1,374.7$ & $1,384.3$ & $1,372.0$ & $1,358.8$ & $1,379.5$ & $1,404.8$ & $1,431.4$ & $1,442.3$ \\
\hline
\end{tabular}

$P=$ preliminary data.

Notes: Data in this table are revised from the data contained in the previous EIA report, Emissions of Greenhouse Gases in the United States 1987-1994, DOE/EIA-0573(87-94) (Washington, DC, October 1995). Emissions coefficients are annualized for coal, motor gasoline, liquefied petroleum gases, jet fuel, and crude oil. Includes emissions from bunker fuels. Totals may not equal sum of components due to independent rounding.

Source: EIA estimates documented in this chapter and in Appendix A.

Table 6. U.S. Carbon Dioxide Emissions from Fossil Energy Consumption by End-Use Sector, 1988-1995 (Million Metric Tons of Carbon)

\begin{tabular}{|c|c|c|c|c|c|c|c|c|}
\hline End Use & 1988 & 1989 & 1990 & 1991 & 1992 & 1993 & 1994 & P1995 \\
\hline \multicolumn{9}{|l|}{ Energy Consumption } \\
\hline Residential ........ & 264.8 & 267.5 & 253.0 & 257.1 & 255.9 & 271.6 & 268.6 & 270.9 \\
\hline Commercial & 207.6 & 210.0 & 206.7 & 206.4 & 205.5 & 212.1 & 214.1 & 218.4 \\
\hline Industrial & 444.1 & 445.6 & 452.4 & 436.6 & 453.6 & 453.7 & 463.3 & 462.9 \\
\hline Transportation & 427.5 & 432.7 & 432.1 & 424.5 & 431.4 & 437.5 & 450.4 & 457.2 \\
\hline Total Energy & $1,344.0$ & $1,355.8$ & $1,344.2$ & $1,324.6$ & $1,346.3$ & $1,375.0$ & $1,396.5$ & $1,409.4$. \\
\hline Electric Utility ${ }^{\mathrm{a}}$ & 475.9 & 483.5 & 476.9 & 473.5 & 472.9 & 490.6 & 494.8 & 493.8 \\
\hline
\end{tabular}

${ }^{a}$ Estimates of additional carbon dioxide emissions from the use of flue gas desulfurization are included in Table 13.

$\mathrm{P}=$ preliminary data.

Notes: Includes energy from petroleum, coal, and natural gas. Electric utility emissions are distributed across consumption sectors. Data in this table are revised from the data contained in the previous EIA report, Emissions of Greenhouse Gases in the United States 1987-1994, DOE/EIA-0573(87-94) (Washington, DC, October 1995). Totals may not equal sum of components due to independent rounding.

Source: EIA estimates documented in this chapter and in Appendix A. 
Table 7. U.S. Carbon Sequestered by Nonfuel Use of Energy, 1988-1995

(Million Metric Tons of Carbon)

\begin{tabular}{|c|c|c|c|c|c|c|c|c|}
\hline End Use & 1988 & 1989 & 1990 & 1991 & 1992 & 1993 & 1994 & P1995 \\
\hline \multicolumn{9}{|l|}{ Industrial } \\
\hline \multicolumn{9}{|l|}{ Petroleum } \\
\hline Liquefied Petroleum Gases . . . . . . . & 16.5 & 17.2 & 17.5 & 19.3 & 19.8 & 22.1 & 24.6 & 24.7 \\
\hline Asphalt and Road Oil $\ldots \ldots \ldots \ldots$ & 23.5 & 22.7 & 22.5 & 22.3 & 22.7 & 23.7 & 24.1 & 24.2 \\
\hline Lubricants ............ & 1.8 & 1.8 & 1.9 & 1.7 & 1.7 & 1.8 & 1.8 & 1.8 \\
\hline Other $\ldots \ldots \ldots \ldots \ldots \ldots \ldots \ldots$ & 22.3 & 22.4 & 19.9 & 25.2 & 26.4 & 25.3 & 26.4 & 25.1 \\
\hline Petrochemical Feed .......... & 15.5 & 15.5 & 12.7 & 17.8 & 18.6 & 18.7 & 19.3 & 18.1 \\
\hline Petroleum Coke . ........... & 2.1 & 1.9 & 2.6 & 2.2 & 3.6 & 2.6 & 2.8 & 2.8 \\
\hline Waxes and Misc. . . . . . . . & 4.8 & 4.9 & 4.6 & 5.2 & 4.2 & 4.1 & 4.3 & 4.2 \\
\hline 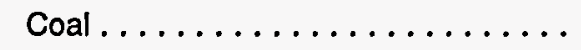 & 0.4 & 0.4 & 0.4 & 0.4 & 0.4 & 0.4 & 0.4 & 0.4 \\
\hline Natural Gas $\ldots \ldots \ldots \ldots \ldots$ & 4.2 & 4.3 & 4.2 & 3.2 & 3.5 & 3.5 & 3.8 & 3.9 \\
\hline \multicolumn{9}{|l|}{ Transportation } \\
\hline Lubricants & 1.7 & 1.7 & 1.8 & 1.6 & 1.6 & 1.7 & 1.7 & 1.7 \\
\hline Total $\ldots \ldots \ldots \ldots \ldots \ldots \ldots$ & 70.4 & 70.5 & 68.1 & 73.7 & $\mathbf{7 6 . 0}$ & 78.4 & 82.8 & 81.9 \\
\hline
\end{tabular}

$P=$ preliminary data.

Note: Data in this table are revised from the data contained in the previous EIA report, Emissions of Greenhouse Gases in the United States 1987-1994, DOE/EIA-0573(87-94) (Washington, DC, October 1995).

Source: ElA estimates documented in this chapter and in Appendix A.

Table 8. U.S. Carbon Dioxide Emissions from Energy Use in the Industrial Sector, 1984-1995 (Million Metric Tons of Carbon)

\begin{tabular}{|c|c|c|c|c|c|c|c|c|c|c|c|c|}
\hline Fuel & 1984 & 1985 & 1986 & 1987 & 1988 & 1989 & 1990 & 1991 & 1992 & 1993 & 1994 & P1995 \\
\hline Petroleum & & & & : & & & & & & & & \\
\hline Motor Gasoline . . . . . . . . & 3.1 & 4.2 & 4.0 & 3.9 & 3.7 & 3.8 & 3.5 & 3.7 & 3.7 & 3.5 & 3.7 & 3.8 \\
\hline LPG $\ldots \ldots \ldots \ldots \ldots \ldots$ & 16.5 & 16.9 & 16.0 & 13.8 & 13.6 & 12.6 & 9.8 & 10.3 & 11.8 & 8.3 & 9.4 & 9.4 \\
\hline Distillate Fuel $\ldots \ldots \ldots \ldots$ & 23.5 & 23.4 & 23.7 & 24.2 & $24.1^{*}$ & 22.7 & 23.3 & 22.5 & 22.6 & 21.7 & 21.9 & 22.1 \\
\hline Residual Fuel $\ldots \ldots \ldots \ldots$ & 18.9 & 15.9 & 15.7 & 12.4 & 11.6 & 8.8 & 8.9 & 7.1 & 8.3 & 9.6 & 8.9 & 7.9 \\
\hline Lubricants $\ldots \ldots \ldots \ldots$ & 1.8 & 1.7 & 1.6 & 1.8 & 1.8 & 1.8 & 1.9 & 1.7 & 1.7 & 1.7 & 1.8 & 1.8 \\
\hline Kerosene ............ & 1.1 & 0.9 & 0.6 & 0.6 & 0.6 & 0.6 & 0.2 & 0.2 & 0.2 & 0.3 & 0.3 & 0.4 \\
\hline Other $\ldots \ldots \ldots \ldots \ldots \ldots$ & 39.0 & 36.7 & 36.7 & 39.8 & 44.9 & 43.8 & 51.5 & 42.9 & 49.8 & 47.1 & .50 .0 & 48.3 \\
\hline Total $\ldots \ldots \ldots \ldots \ldots$ & 103.9 & 99.7 & 98.3 & 96.5 & 100.3 & 94.0 & 99.2 & 88.4 & 98.1 & 92.2 & 96.0 & 93.6 \\
\hline Coal $\ldots \ldots \ldots \ldots \ldots \ldots$ & 69.5 & 67.4 & 64.7 & 66.0 & 71.2 & 69.5 & 68.5 & 64.8 & 63.0 & 62.3 & 62.9 & 62.2 \\
\hline Natural Gas . . . . . . . . . & 104.2 & 99.0 & 93.3 & 102.0 & 107.0 & 113.1 & 118.5 & 121.2 & 126.1 & 131.7 & 134.5 & 140.7 \\
\hline Electricity . . . . . . . . . & 156.8 & 158.0 & 152.7 & 158.1 & 165.5 & 169.1 & 166.2 & 162.3 & 166.5 & 167.5 & 169.9 & 166.4 \\
\hline Total $\ldots \ldots \ldots \ldots$ & 434.4 & 424.1 & 409.0 & 422.7 & 444.1 & 445.6 & 452.4 & 436.6 & 453.6 & 453.7 & 463.3 & 462.9 \\
\hline
\end{tabular}

$P=$ preliminary data.

Notes: Data in this table are revised from the data contained in the previous EIA report, Emissions of Greenhouse Gases in the United States 1987-1994, DOE/EIA0573(87-94) (Washington, DC, October 1995). Totals may not equal sum of components due to independent rounding.

Source: Energy Information Administration estimates, based on energy data from State Energy Data Report 1994, DOE/EIA-0214(94) (Washington, DC, July 1996), and Monthly Energy Review, DOE/EIA-0535(96/07) (Washington, DC, July 1996), and emissions coefficients shown in Table B1 of this report. 
Table 9. U.S. Carbon Dioxide Emissions from Energy Use in the Transportation Sector, 1984-1995 (Million Metric Tons of Carbon)

\begin{tabular}{|c|c|c|c|c|c|c|c|c|c|c|c|c|}
\hline Fuel & 1984 & 1985 & 1986 & 1987 & 1988 & 1989 & 1990 & 1991 & 1992 & 1993 & 1994 & P1995 \\
\hline \multicolumn{13}{|l|}{ Petroleum } \\
\hline Motor Gasoline . & 241.6 & 245.1 & 252.8 & 259.0 & 264.9 & 264.2 & 260.9 & 259.5 & 263.4 & 270.1 & 274.7 & 280.7 \\
\hline LPG. & 0.7 & 0.5 & 0.4 & 0.3 & 0.4 & 0.4 & 0.4 & 0.3 & 0.3 & 0.3 & 0.5 & 0.5 \\
\hline Jet Fuel & 46.5 & 48.0 & 51.6 & 54.6 & 57.3 & 58.8 & 60.1 & 58.1 & 57.6 & 58.1 & 60.4 & 60.0 \\
\hline Distillate Fuel .. & 62.1 & 63.3 & 65.3 & 66.9 & 72.9 & 75.8 & 75.7 & 72.6 & 75.3 & 77.3 & 82.5 & 83.8 \\
\hline Residual Fuel .. & 17.2 & 16.7 & 18.5 & 19.2 & 19.6 & 20.8 & 21.9 & 22.0 & 23.0 & 19.4 & 19.1 & 18.5 \\
\hline Lubricants & 1.7 & 1.6 & 1.5 & 1.7 & 1.7 & 1.7 & 1.8 & 1.6 & 1.6 & 1.6 & 1.7 & 1.7 \\
\hline Aviation Gas.. & 0.8 & 0.9 & 1.1 & 0.9 & 0.9 & 0.9 & 0.8 & 0.8 & 0.8 & 0.7 & 0.7 & 0.7 \\
\hline Total $\ldots . . . \ldots$ & 370.5 & 376.1 & 391.2 & 402.7 & 417.6 & 422.6 & 421.5 & 414.8 & 421.9 & 427.6 & 439.6 & 445.9 \\
\hline Natural Gas ... & 7.8 & 7.5 & 7.2 & 7.7 & 9.1 & 9.4 & 9.8 & 8.9 & 8.8 & 9.3 & 10.2 & 10.6 \\
\hline Electricity ... & 0.7 & 0.7 & 0.7 & 0.7 & 0.7 & 0.7 & 0.7 & 0.7 & 0.7 & 0.7 & 0.7 & 0.6 \\
\hline Total ..... & 379.0 & 384.4 & 399.1 & 411.1 & 427.5 & 432.7 & 432.1 & 424.5 & 431.4 & 437.5 & 450.4 & 457.2 \\
\hline
\end{tabular}

$P=$ preliminary data.

Notes: Data in this table are revised from the data contained in the previous ElA report, Emissions of Greenhouse Gases in the United States 1987-1994, DOEIEIA0573(87-94) (Washington, DC, October 1995). Totals may not equal sum of components due to independent rounding.

Source: Energy Information Administration estimates, based on energy data from State Energy Data Report 1994, DOE/EIA-0214(94) (Washington, DC, July 1996), and Monthly Energy Review, DOE/EIA-0535(96/07) (Washington, DC, July 1996), and emissions coefficients shown in Table B1 of this report.

Table 10. U.S. Carbon Dioxide Emissions from Energy Use in the Residential Sector, 1984-1995 (Million Metric Tons of Carbon)

\begin{tabular}{|c|c|c|c|c|c|c|c|c|c|c|c|c|}
\hline Fuel & 1984 & 1985 & 1986 & 1987 & 1988 & 1989 & 1990 & 1991 & 1992 & 1993 & 1994 & P1995 \\
\hline \multicolumn{13}{|l|}{ Petroleum } \\
\hline LPG. & 4.9 & 5.5 & 5.5 & 6.1 & 6.0 & 6.8 & 6.2 & 6.6 & 6.5 & 6.7 & 6.7 & 6.7 \\
\hline Distillate Fuel ..... & 19.0 & 19.7 & 20.0 & 20.3 & 21.0 & 20.6 & 16.5 & 16.4 & 17.1 & 18.0 & 17.4 & 17.6 \\
\hline Kerosene $\ldots \ldots \ldots \ldots$ & 1.7 & 3.1 & 2.4 & 2.3 & 2.8 & 2.3 & 1.2 & 1.4 & 1.3 & 1.5 & 1.3 & 1.4 \\
\hline Total ......... & 25.6 & 28.3 & 27.8 & 28.8 & 29.8 & 29.7 & 24.0 & 24.4 & 24.8 & 26.2 & 25.3 & 25.8 \\
\hline Coal $\ldots \ldots \ldots \ldots$ & 2.1 & 1.8 & 1.8 & 1.7 & 1.7 & 1.5 & 1.6 & 1.4 & 1.5 & 1.5 & 1.4 & 1.4 \\
\hline Natural Gas $\ldots . . . \ldots$ & 67.5 & 65.7 & 63.8 & 63.9 & 68.5 & 70.9 & 65.1 & 67.5 & 69.4 & 73.4 & 71.8 & 72.4 \\
\hline Electricity ....... & 146.0 & 149.9 & 150.6 & 156.7 & 164.8 & 165.4 & 162.4 & 163.8 & 160.2 & 170.6 & 170.0 & 171.3 \\
\hline Total...$\ldots \ldots$. & 241.1 & 245.8 & 244.0 & 251.0 & 264.8 & 267.5 & 253.0 & 257.1 & 255.9 & 271.6 & 268.6 & 270.9 \\
\hline
\end{tabular}

$P=$ preliminary data.

Notes: Data in this table are revised from the data contained in the previous ElA report, Emissions of Greenhouse Gases in the United States 1987-1994, DOE/EIA0573(87-94) (Washington, DC, October 1995). Totals may not equal sum of components due to independent rounding.

Source: Energy Information Administration estimates, based on energy data from State Energy Data Report 1994, DOE/EIA-0214(94) (Washinglon, DC, July 1996), and Monthly Energy Review, DOE/EIA-0535(96/07) (Washington, DC, July 1996), and emissions coefficients shown in Table B1 of this report.

Table 11. U.S. Carbon Dioxide Emissions from Energy Use in the Commercial Sector, 1984-1995 (Million Metric Tons of Carbon)

\begin{tabular}{|c|c|c|c|c|c|c|c|c|c|c|c|c|}
\hline Fuel & 1984 & 1985 & 1986 & 1987 & 1988 & 1989 & 1990 & 1991 & 1992 & 1993 & 1994 & P1995 \\
\hline \multicolumn{13}{|l|}{ Petroleum } \\
\hline Motor Gasoline . . . . . . . . . & 2.1 & 1.8 & 2.0 & 2.1 & 2.1 & 2.0 & 2.1 & 1.6 & 1.5 & 0.6 & 0.5 & 0.5 \\
\hline LPG $\ldots \ldots \ldots \ldots \ldots$ & 0.9 & 1.0 & 1.0 & 1.1 & 1.1 & 1.2 & 1.1 & 1.2 & 1.1 & 1.2 & 1.2 & 1.2 \\
\hline Distillate Fuel $\ldots \ldots \ldots \ldots$ & 13.5 & 12.3 & 11.8 & 11.7 & 11.3 & 10.6 & 9.6 & 9.5 & 9.2 & 9.2 & 9.2 & 9.3 \\
\hline Residual Fuel . . . . . . . & 5.6 & 4.8 & 6.2 & 5.6 & 5.6 & 4.9 & 5.0 & 4.5 & 4.1 & 3.7 & 3.7 & 3.6 \\
\hline Kerosene . . . . . . . . . . & 1.8 & 0.6 & 1.0 & 0.9 & 0.5 & 0.5 & 0.2 & 0.2 & 0.2 & 0.3 & 0.4 & 0.4 \\
\hline Total $\ldots \ldots \ldots \ldots \ldots$ & 23.8 & 20.6 & 21.9 & 21.4 & 20.6 & 19.2 & 18.0 & 17.1 & 16.1 & 14.9 & 14.9 & 15.0 \\
\hline Coal $\ldots \ldots \ldots \ldots \ldots$ & 3.2 & 2.7 & 2.7 & 2.6 & 2.6 & 2.3 & 2.4 & 2.2 & 2.2 & 2.2 & 2.1 & 2.1 \\
\hline Natural Gas . . . . . . . . . & 37.3 & 36.0 & 34.3 & 36.0 & 39.5 & 40.3 & 38.8 . & 40.4 & 41.5 & 43.1 & 42.9 & 45.9 \\
\hline Electricity . . . . . . . . . & 124.4 & 130.2 & 131.5 & 137.2 & 144.8 & 148.3 & 147.5 & 146.7 & 145.6 & 151.8 & 154.1 & 155.5 \\
\hline Total .............. & 188.8 & 189.6 & 190.4 & 197.2 & 207.6 & 210.0 & 206.7 & 206.4 & 205.5 & 212.1 & 214.1 & 218.4 \\
\hline
\end{tabular}

$P=$ preliminary data.

Notes: Data in this table are revised from the data contained in the previous ElA report, Emissions of Greenhouse Gases in the United States 1987-1994, DOE/EIA0573(87-94) (Washington, DC, October 1995). Totals may not equal sum of components due to independent rounding.

Source: Energy Information Administration estimates, based on energy data from State Energy Data Report 1994, DOE/EIA-0214(94) (Washington, DC, July 1996), and Monthly Energy Review, DOE/EIA-0535(96/07) (Washington, DC, July 1996), and emissions coefficients shown in Table B1 of this report. 
Table 12. U.S. Carbon Dioxide Emissions from Electric Utilities, 1984-1995 (Million Metric Tons of Carbon)

\begin{tabular}{|c|c|c|c|c|c|c|c|c|c|c|c|c|}
\hline Fuel & 1984 & 1985 & 1986 & 1987 & 1988 & 1989 & 1990 & 1991 & 1992 & 1993 & 1994 & P1995 \\
\hline Petroleum . . . . . . . . . & 27.3 & 23.1 & 30.8 & 26.7 & 33.2 & 35.7 & 26.6 & 25.1 & 20.3 & 22.5 & 20.6 & 14.0 \\
\hline Heavy Fuel Oil . . . . . . . . & 25.3 & 21.2 & 28.9 & 24.6 & 30.7 & 32.4 & 24.2 & 22.9 & 18.2 & 20.0 & 18.0 & 11.6 \\
\hline Light Fuel On $\ldots \ldots \ldots \ldots$ & 1.7 & 1.7 & 1.6 & 1.8 & 2.2 & 2.9 & 1.7 & 1.6 & 1.3 & 1.5 & 1.9 & 1.8 \\
\hline Petroleum Coke . . . . . . & 0.2 & 0.2 & 0.3 & 0.3 & 0.3 & 0.4 & 0.7 & 0.6 & 0.8 & 1.0 & 0.7 & 0.6 \\
\hline Coal $\ldots \ldots \ldots \ldots \ldots \ldots$ & 354.3 & 370.3 & 365.9 & 383.7 & 403.7 & 406.5 & 409.0 & 407.3 & 411.9 & 428.6 & 430.2 & 432.8 \\
\hline Natural Gas . . . . . . . . . . & 46.3 & 45.5 & 38.7 & 42.2 & 39.0 & 41.2 & 41.2 & 41.1 & 40.7 & 39.5 & 44.0 & 47.0 \\
\hline Total $\ldots \ldots \ldots \ldots \ldots$ & 427.9 & 438.9 & 435.4 & 452.6 & 475.9 & 483.5 & 476.9 & 473.5 & 472.9 & 490.6 & 494.8 & 493.8 \\
\hline
\end{tabular}

$P=$ preliminary data.

Notes: Electric utilities include Independent Power Producers but exclude cogeneration facilities. Data in this table are revised from the data contained in the previous EIA report, Emissions of Greenhouse Gases in the United States 1987-1994, DOE/EIA-0573(87-94) (Washington, DC, October 1995). Totals may not equal sum of components due to independent rounding.

Source: Energy Information Administration estimates, based on energy data from State Energy Data Report 1994, DOE/EIA-0214(94) (Washington, DC, July 1996), and Monthly Energy Review, DOE/EIA-0535(96/07) (Washington, DC, July 1996), and emissions coefficients shown in Table B1 of this report.

Table 13. U.S. Carbon Dioxide Emissions from Gas Flaring, 1988-1995

\begin{tabular}{|c|c|c|c|c|c|c|c|c|}
\hline Item & 1988 & 1989 & 1990 & 1991 & 1992 & 1993 & 1994 & P1995 \\
\hline Basic Data & & & & & & & & \\
\hline $\begin{array}{l}\text { Total Natural Gas Vented and Flared } \\
\text { (Billion Cubic Feet) ........... }\end{array}$ & 102.18 & 101.56 & 111.08 & 127.64 & 124.23 & 175.92 & 176.83 & 108.97 \\
\hline $\begin{array}{l}\text { Btu Content of Flare Gas } \\
\text { (Btu per Cubic Foot) } \ldots \ldots \ldots \ldots\end{array}$ & 1,109 & 1,107 & 1,105 & 1,108 & 1,110 & 1,106 & 1,106 & 1,106 \\
\hline $\begin{array}{l}\text { Carbon Emissions from Flaring } \\
\text { (Million Metric Tons) . . . . . . . }\end{array}$ & 1.69 & 1.68 & 1.83 & 2.11 & 2.06 & 2.90 & 2.92 & 1.80 \\
\hline
\end{tabular}

$P=$ preliminary data.

Note; Data in this table are revised from the data contained in the previous EIA report, Emissions of Greenhouse Gases in the United States 1987-1994, DOE/EIA-0573(87-94) (Washington, DC, October 1995).

Sources: Energy Information Administration, Natural Gas Annual, DOE/ElA-0131 (Washington, DC, 1987-1994), and Natural Gas Monthly, DOE/EIA-0130(96/05) (Washington, DC, May 1996); and U.S. Department of Energy, An Evaluation of the Relationship Between the Production and Use of Energy and Atmospheric Methane Emissions, DOE/NBB-0088P (Washington, DC, April 1990). 
Table 14. U.S. Carbon Dioxide Emissions from Industrial Sources, 1988-1995 (Million Metric Tons of Carbon)

\begin{tabular}{|c|c|c|c|c|c|c|c|c|}
\hline Source & 1988 & 1989 & 1990 & 1991 & 1992 & 1993 & 1994 & P1995 \\
\hline \multicolumn{9}{|l|}{ Cement Manufacture } \\
\hline Clinker Production $\ldots \ldots \ldots \ldots$ & 8.67 & 8.69 & 8.75 & 8.51 & 8.59 & 9.09 & 9.64 & 10.49 \\
\hline Masonry Cement $\ldots \ldots \ldots \ldots$ & 0.02 & 0.02 & 0.02 & 0.02 & 0.02 & 0.02 & 0.02 & 0.02 \\
\hline Total $\ldots \ldots \ldots \ldots \ldots \ldots$ & 8.69 & 8.71 & 8.77 & 8.53 & 8.61 & 9.11 & 9.67 & 10.52 \\
\hline \multicolumn{9}{|l|}{ Other Industrial } \\
\hline Limestone Consumption & & & & & & & & 1 \\
\hline Lime Manufacture . . . . . . . . & 3.31 & 3.33 & 3.39 & 3.36 & 3.47 & 3.63 & 3.70 & 3.96 \\
\hline Iron Smelting $\ldots \ldots \ldots \ldots \ldots$ & 0.50 & 0.51 & 0.47 & 0.44 & 0.37 & 0.31 & 0.52 & 0.52 \\
\hline Steelmaking . . . . . . . . & 0.10 & 0.13 & 0.08 & 0.09 & 0.07 & 0.13 & 0.15 & 0.15 \\
\hline Glass Manufacture . . . . . . . & 0.06 & 0.03 & 0.03 & 0.03 & 0.04 & 0.05 & 0.07 & 0.07 \\
\hline Flue Gas Desulfurization . . . . . & 0.45 & 0.53 & 0.52 & 0.55 & 0.54 & 0.51 & 0.55 & 0.70 \\
\hline Total $\ldots \ldots \ldots \ldots \ldots \ldots$ & 4.43 & 4.53 & 4.50 & 4.46 & 4.49 & 4.63 & 5.00 & 5.40 \\
\hline Dolomite Consumption $\ldots . .$. & 0.12 & 0.08 & 0.09 & 0.10 & 0.08 & 0.07 & 0.08 & 0.08 \\
\hline Soda Ash Manufacture . . . . . . & 0.86 & 0.93 & 0.92 & 0.92 & 0.94 & 0.91 & 0.92 & 1.04 \\
\hline \multicolumn{9}{|l|}{ Soda Ash Consumption } \\
\hline Glass Manufacture . . . . . . . & 0.38 & 0.37 & 0.36 & 0.34 & 0.35 & 0.35 & 0.36 & 0.35 \\
\hline Flue Gas Desulfurization . . . . . & 0.02 & 0.03 & 0.02 & 0.02 & 0.02 & 0.02 & 0.02 & 0.02 \\
\hline Sodium Silicate $\ldots \ldots \ldots \ldots$ & 0.05 & 0.05 & 0.05 & 0.05 & 0.05 & 0.06 & 0.06 & 0.07 \\
\hline Sodium Tripolyphosphate ... & 0.04 & 0.04 & 0.04 & 0.03 & 0.03 & 0.03 & 0.03 & 0.03 \\
\hline Total $\ldots \ldots \ldots \ldots \ldots$ & 0.50 & 0.49 & 0.46 & 0.44 & 0.45 & 0.46 & 0.47 & 0.48 \\
\hline Carbon Dioxide Manufacture ... & 0.22 & 0.23 & 0.24 & 0.25 & 0.26 & 0.26 & 0.27 & 0.29 \\
\hline Aluminum Production $\ldots \ldots \ldots$ & 1.99 & 2.03 & 2.04 & 2.08 & 2.04 & 1.86 & 1.66 & 1.69 \\
\hline Total Other Industrial . . . . . & 8.11 & 8.30 & 8.26 & 8.26 & 8.27 & 8.20 & 8.41 & 8.97 \\
\hline Total $\ldots \ldots \ldots \ldots \ldots \ldots \ldots$ & 16.80 & 17.00 & 17.03 & 16.79 & 16.88 & 17.31 & 18.08 & 19.49 \\
\hline
\end{tabular}

$P=$ preliminary data.

Notes: Data in this table are revised from the data contained in the previous ElA report, Emissions of Greenhouse Gases in the United States 1987-1994, DOE/EIA-0573(87-94) (Washington, DC, October 1995). Totals may not equal sum of components due to independent rounding.

Sources: Methodologies and sources of trend data documented in Appendix A.

Table 15. Carbon Emissions from U.S. Territories, International Bunkers, and Unmetered Gas Consumption, 1988-1995

(Million Metric Tons of Carbon)

\begin{tabular}{c|r|r|r|r|r|r|r|r}
\hline Item & $\mathbf{1 9 8 8}$ & 1989 & $\mathbf{1 9 9 0}$ & 1991 & 1992 & 1993 & 1994 & P1995 \\
\hline U.S. Territories $\ldots \ldots \ldots \ldots \ldots \ldots \ldots \ldots$ & 8.5 & 9.4 & 9.3 & 10.9 & 9.9 & 10.7 & 12.5 & 10.7 \\
Bunker Fuels $\ldots \ldots \ldots \ldots \ldots \ldots \ldots \ldots$ & 20.7 & 21.9 & 21.7 & 22.9 & 24.2 & 21.8 & 21.0 & NA \\
Unmetered Natural Gas Consumption $\ldots$ & 3.7 & 0.4 & -0.4 & 4.4 & 4.3 & -1.1 & 1.4 & 0.9. \\
\hline
\end{tabular}

$P=$ preliminary data. $N A=$ not available.

Note: Data in this table are revised from the data contained in the previous EIA report, Emissions of Greenhouse Gases in the United States 1987-1994, DOE/EIA-0573(87-94) (Washington, DC, October 1995).

Source: Estimates documented in this chapter. 


\section{Methane Emissions}

\section{Overview}

\begin{tabular}{|c|c|c|}
\hline \multicolumn{3}{|c|}{$\begin{array}{l}\text { U.S. Anthropogenic Methane Emissions, } \\
\text { 1990-1994 }\end{array}$} \\
\hline & Methane & $\begin{array}{l}\text { Carbon } \\
\text { Equivalent }\end{array}$ \\
\hline $\begin{array}{l}\text { Estimated } 1994 \text { Emissions } \\
\text { (Million Metric Tons) }\end{array}$ & 31.0 & 177.5 \\
\hline $\begin{array}{l}\text { Change Compared to } 1993 \\
\text { (Million Metric Tons) }\end{array}$ & 0.5 & 3.0 \\
\hline $\begin{array}{l}\text { Change from } 1993 \\
\text { (Percent) }\end{array}$ & 1.7 & 1.7 \\
\hline $\begin{array}{l}\text { Change Compared to } 1990 \\
\text { (Million Metric Tons) }\end{array}$ & -0.3 & -1.9 \\
\hline $\begin{array}{l}\text { Change from } 1990 \\
\text { (Percent) }\end{array}$ & -1.1 & -1.1 \\
\hline
\end{tabular}

Estimated U.S. anthropogenic methane emissions totaled 31.0 million metric tons in 1994, an increase of 530,000 metric tons from 1993, though still well below the total of 31.3 million metric tons emitted in 1990 (Table 16). In terms of tons of gas emitted, methane emissions are dwarfed by carbon dioxide emissions (a ratio of 1 ton of methane for every 175 tons of carbon dioxide). Yet, because the heat-trapping capacity of methane is some 21 times that of carbon dioxide, the overall effect of methane on global climate is significant. After weighting emissions by the global warming potential of each gas, methane represents 10 percent of all U.S. anthropogenic emissions. There is, however, substantial uncertainty in estimates of emissions from most U.S. sources, ranging from 25 percent to as high as several hundred percent. Thus, trends in emissions from each source tend to be more reliable than their overall estimated magnitude. ${ }^{27}$

Between 1990 and 1994, total methane emissions declined by 1 percent. Methane emissions are dominated by three sources: energy production and consumption, waste management, and agriculture (Figure 6). ${ }^{28} \mathrm{De}-$ creases in emissions from energy and agriculture were for the most part offset by increases in emissions from agriculture and industrial processes (Figure 6). Energy sources account for 37 percent of emissions, while waste management and agriculture contribute about one-third each. Emissions from industrial processes contribute less than 0.5 percent of the total.

\section{Figure 6. U.S. Methane Emissions by Source, 1990 and 1994}

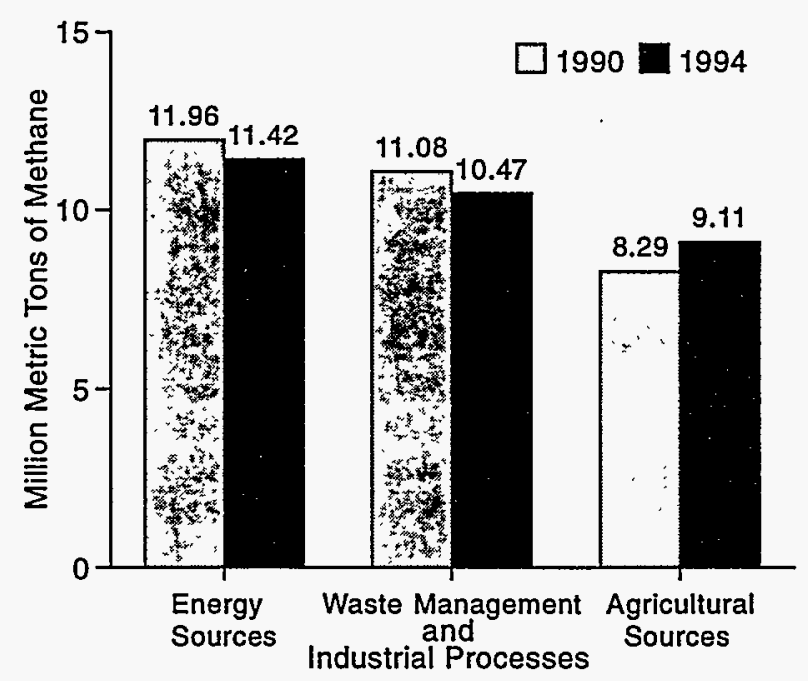

Source: Estimates presented in this chapter.

\footnotetext{
${ }^{27}$ Wherever possible, methane emissions estimates are based on measured data. In most cases, however, little if any measured data is available. In the absence of measured data, emissions are calculated by multiplying some known activity data, such as coal production or natural gas throughput, by an emissions factor derived from a small sample of the relevant emissions source or through laboratory experiments. For a more detailed discussion of where measured data were used, and how emission factors were developed, see Appendix A. The absence of measured emissions data for most sources of methane emissions and the reliance on emissions factors is a significant source of uncertainty. For more specific information on the individual sources of uncertainty, see Appendix $C$.

${ }^{28}$ It should be noted that the grouping of methane emissions is presented for analytical purposes (primarily source comparisons between gases) and for consistency between chapters in this report. If sources of methane emissions were looked at individually, four sources-coal mining; oil and gas production, processing, and distribution; landfills; and livestock management-would represent 95 percent of methane emissions. All the other sources together-stationary combustion, transportation, wastewater treatment, rice paddies, agricultural residues, and industrial processes-would account for a mere 5 percent of emissions.
} 
Major Sources of U.S. Methane Emissions, 1990-1994

\begin{tabular}{|c|c|c|c|c|}
\hline \multirow[b]{2}{*}{ Source } & \multicolumn{2}{|c|}{$\begin{array}{l}\text { Million Metric } \\
\text { Tons Methane }\end{array}$} & \multicolumn{2}{|c|}{$\begin{array}{l}\text { Percent } \\
\text { Change }\end{array}$} \\
\hline & 1990 & 1994 & $\begin{array}{l}1990- \\
1994\end{array}$ & $\begin{array}{l}1993- \\
1994\end{array}$ \\
\hline Energy & 11.96 & 11.42 & -4.6 & 4.1 \\
\hline $\begin{array}{l}\text { Waste } \\
\text { Management }\end{array}$ & 10.96 & 10.34 & -5.7 & -2.3 \\
\hline Agriculture & 8.29 & 9.11 & 9.9 & 3.7 \\
\hline $\begin{array}{l}\text { Industrial } \\
\text { Processes }\end{array}$ & 0.12 & 0.13 & 11.6 & 5.6 \\
\hline
\end{tabular}

Although methane emissions from energy sources increased between 1993 and 1994, they have declined by 550,000 metric tons or some 4.6 percent since 1990, mainly due to decreases in emissions at the Nation's gassiest coal mines (Figure 7). Emissions from waste management (especially landfills) decreased by nearly 6 percent between 1990 and 1994 because of a continuing decline in the annual volume of waste being landfilled, combined with a steady increase in methane recovery. In contrast, emissions from agriculture have increased by 820,000 metric tons, or nearly 10 percent, since 1990. This was due to concurrent increases in average animal size and populations and a shift in the management of dairy cattle waste to higher emitting systems in several States.

Figure 7. Difference in U.S. Methane Emissions by Source, 1990 vs. 1994

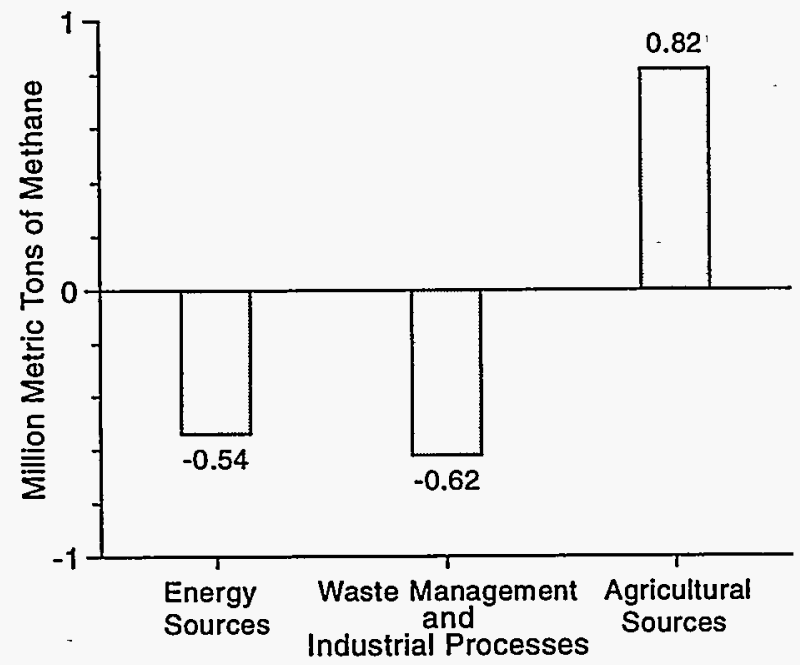

Source: Estimates presented in this chapter.
Preliminary estimates of emissions for 1995 suggest that overall emissions can be expected to remain flat or decline slightly. Animal sizes and populations have stabilized, while venting of associated gas from oil wells appears to have declined, neutralizing two potential sources of emissions growth. Further, underground coal production in 1995 was down by 4 percent from 1994 levels, and the trend toward increased curbside recycling and landfill methane recovery continues.

\section{Energy Sources}

In 1994 energy sources accounted for 11.4 million tons of methane emissions, including nearly 7 million tons from the largest source, oil and gas production and distribution; almost 4 million metric tons from coal mining; and the remainder from stationary combustion and transportation. Although methane emissions from energy sources increased by 4.1 percent between 1993 and 1994, they are nearly 5 percent lower than in 1990. Each source is discussed in the following sections, beginning with the largest source, oil and gas production and distribution.

\section{Oil and Gas Production, Processing, and Distribution}

\begin{tabular}{|c|c|}
\hline $\begin{array}{l}\text { Estimated } 1994 \text { Emissions } \\
\text { (Million Metric Tons Methane) }\end{array}$ & 6.89 \\
\hline $\begin{array}{l}\text { Change Compared to } 1993 \\
\text { (Million Metric Tons Methane) }\end{array}$ & 0.12 \\
\hline Change from 1993 (Percent) & 1.7 \\
\hline $\begin{array}{l}\text { Change Compared to } 1990 \\
\text { (Million Metric Tons Methane) }\end{array}$ & 0.30 \\
\hline Change from 1990 (Percent) & 4.6 \\
\hline
\end{tabular}

Methane emissions from oil and gas operations have shown a slow upward trend over much of the past decade, rising at a rate of just over 1 percent a year between 1988 and 1994 (Table 17). About one-half of this increase is attributable to an increase in emissions from the venting of associated gas at oil wells. A large portion of the remaining growth has occurred as a result of fugitive emissions at gas processing plants and gate stations. While the growth in estimated emissions 


\section{New Research Used To Improve Estimates of Methane Emissions from Oil and Gas Operations}

A recently completed study jointly funded and managed by the U.S. Environmental Protection Agency (EPA) and the Gas Research Institute (GRI) indicates that methane emissions from the U.S. natural gas industry are substantially higher than previously estimated. This study estimated 1992 emissions from the U.S. natural gas industry, excluding gas vented at oil wells, at 5.83 million metric tons-more than double the estimate of 2.57 million metric tons provided in last year's edition of Emissions of Greenhouse Gases in the United States, which was largely based on an earlier EPA study, Anthropogenic Methane Emissions in the United States: Estimates for 1990. In its earlier study, the EPA estimated 1990 methane emissions from the natural gas industry at about 3 million metric tons. Although the revised estimate is subject to less uncertainty than previous estimates, it still is only accurate to plus or minus 50 percent. (A more complete discussion of the uncertainty associated with this estimate appears in Appendix C.)

The differences between the earlier EPA study and the more recent joint EPA/GRI effort center on data availability and sample size. The more recent study benefits from a more complete inventory of equipment components in the natural gas industry as well as a larger and more representative sample used to estimate emissions from each component. For example, the earlier study based emissions estimates from transmission and distribution pipelines on two leakage studies conducted by Pacific Gas and Electric and Southern California Edison. Because these systems use very little cast iron pipe, data collected on their leakage rates grossly underestimated more typical pipeline leakage rates. Using these leakage rates when making calculations of emissions from pipelines results in estimates substantially lower than those that result from the use of emissions factors derived from data in the more recent EPA/GRI study, which better represents the quality of the existing capital stock. (A comparison of the old and revised emission factors is provided in Appendix A.)

The table below compares the estimated 1992 emissions from the oil and gas system appearing in last year's edition of Emissions of Greenhouse Gases in the United States with this year's estimate. Of the approximately 3.3 million metric ton difference in the estimates, more than 1.5 million metric tons can be attributed to previously unavailable data on emissions from pneumatic devices during production; emissions from compressors during processing, transmission, and storage; leakage from distribution pipeline; and emissions from metering and pressure regulating stations.

Change in EIA Estimates of 1992 U.S. Methane Emissions from Oil and Gas Operations (Million Metric Tons of Methane)

\begin{tabular}{|c|c|c|c|}
\hline Source of 1992 Emissions & Last Year's Report & Current Estimate & Difference \\
\hline \multicolumn{4}{|l|}{ Oil and Gas Production } \\
\hline Natural Gas Wellheads $\ldots \ldots \ldots \ldots \ldots \ldots$ & 0.24 & 0.30 & 0.06 \\
\hline Oil Wells $\ldots \ldots \ldots \ldots \ldots \ldots \ldots \ldots \ldots$ & 0.04 & 0.04 & * \\
\hline Gathering Pipelines $\ldots \ldots \ldots \ldots \ldots \ldots \ldots$ & 0.31 & 1.03 & 0.72 \\
\hline Gas Processing Plants $\ldots \ldots \ldots \ldots \ldots \ldots$ & 0.10 & 0.68 & 0.58 \\
\hline Heaters, Separators, Dehydrators $\ldots \ldots \ldots$. & 0.48 & 0.17 & -0.31 \\
\hline Total $\ldots \ldots \ldots \ldots \ldots \ldots \ldots \ldots \ldots$ & 1.18 & 2.23 & 1.05 \\
\hline Gas Venting $\ldots \ldots \ldots \ldots \ldots \ldots \ldots \ldots \ldots$ & 0.83 & 0.83 & * \\
\hline Gas Transmission Pipelines.$\ldots \ldots \ldots \ldots \ldots$ & 1.06 & 2.17 & 1.11 \\
\hline Distribution Systems $\ldots \ldots \ldots \ldots \ldots \ldots \ldots$ & 0.34 & 1.48 & 1.14 \\
\hline Oil Refining and Transportation $\ldots \ldots \ldots \ldots$ & 0.08 & 0.08 & - \\
\hline Total $\ldots \ldots \ldots \ldots \ldots \ldots \ldots \ldots \ldots$ & 3.48 & 6.78 & 3.30 \\
\hline
\end{tabular}


from gas processing plants and gate stations is the direct result of rising demand for natural gas, which has increased throughput at each stage of the gas distribution system, the cause of the increase in venting at associated gas wells is unknown. ${ }^{29}$ Further, the growth in emissions from venting appears to have reversed itself in $1995 .^{30}$

Preliminary estimates show emissions from venting declining by 330,000 metric tons, or about 33 percent, between 1994 and 1995. This decrease is likely to be only partially offset by emissions growth in other parts of the oil and gas distribution system, leading to a more general decline in emissions from U.S. oil and gas operations. Estimates of emissions from portions of the natural gas system other than gas venting are scaled to measures of capital stock, such as pipeline mileage, and measures of production, such as throughput. ${ }^{31}$ These measures are very unlikely to grow at a rate comparable to the decline in gas venting, leading to lower overall emissions estimates for 1995.

\section{Coal Mining}

U.S. Methane Emissions from Coal Mining,
1990-1994
Estimated 1994 Emissions
(Million Metric Tons Methane)

Despite record U.S. coal production of more than 1 billion short tons during 1994, methane emissions from coal mining remained well below their historic 1990 high of 4.64 million metric tons (Table 18). While coal production in most regions rebounded close to or above production levels seen prior to 1993, production in the gassiest basin, Warrior, continued to decline to a point nearly 20 percent below 1990 levels (see Appendix A) ${ }^{32}$ This trend away from production in the Nation's gassiest mines is underscored by the decline in production at mines with degasification systems in place. Degasification systems are employed in mines where methane volumes are too high to be practically reduced with standard ventilation techniques. Thirty mines are known to have such systems in place, and emissions from these systems represent just under one-third of all emissions from U.S. coal mining operations. However, production in these 30 mines has declined by 27 percent since 1990, reducing estimated emissions by more than 440,000 metric tons. ${ }^{33}$ Further, the quantity of methane recovered at coal mines increased by more than 200,000 metric tons between 1990 and 1994.

The one notable area of growth in emissions from coal mining is surface mining. Record levels of coal production were largely driven by surface mining, which produced at a rate 5 percent above earlier levels. This effective shift from production in the Nation's gassiest underground mines to production from surface mines has significant emissions implications. A ton of coal mined in the Nation's gassiest underground mines may result in methane emissions that are, on average, 50 times greater than a ton of coal mined on the surface. The shift from underground mining to surface mining can be credited to the vast advantages in productivity found in surface coal mining as well as the need for the lower sulfur coal produced in Western surface mines to comply with the provisions of the Clean Air Act Amendments of 1990.

\footnotetext{
${ }^{29}$ For a detailed discussion of the uncertainty associated with these estimates, see Appendix $C$.

${ }^{30}$ The Environmental Protection Agency believes that the 55 companies participating in its Natural Gas STAR program have together avoided 70,000 metric tons of methane emissions in 1994 and an additional 100,000 tons in 1995. Program participants report annually on emissions reductions achieved through such activities as equipment replacement, enhanced inspection and maintenance, and improved operations management. Participating companies may either use their own techniques to estimate reductions achieved or employ default values developed by the Environmental Protection Agency and the Gas Research Institute.

${ }^{31}$ For a more comprehensive explanation of the estimation methods used, see Appendix $\mathrm{A}$.

${ }^{32}$ The Warrior basin includes all coal operations in Alabama.

${ }^{33}$ In this report, estimates of methane emissions from coal mines imply a direct linear relationship between coal production and methane emissions. This is a result of the estimation methods employed. However, there are many variables, such as mine depth, mining technique, amount of coal face exposed, and mine age, that affect emissions levels. Thus, for each mine, it is more likely that emissions can be represented by some constant plus a production variable. This intuition is supported by a study of three inactive mines, conducted by Piccot et al., which found emissions levels 50 to 80 percent of those during active mining. Because establishing a proper constant for each mine in the United States is nearly impossible, this report uses a simpler method that can be generalized to the coal basin level. While this technique introduces some error, the magnitude of the associated uncertainty decreases at the very high level of production seen in U.S. coal mines. For a more detailed discussion of the methods used to estimate emissions from coal mines, see Appendix A. See Appendix $\mathrm{C}$ for an explanation of the uncertainty associated with the emissions estimates.
} 


\section{Stationary Combustion}

\begin{tabular}{|l|}
\hline U.S. Methane Emissions from Stationary \\
Combustion, 1990-1994 \\
Estimated 1994 Emissions \\
(Thousand Metric Tons Methane) \\
Change Compared to 1993 \\
(Thousand Metric Tons Methane) \\
Change from 1993 (Percent)
\end{tabular}

Methane emissions from stationary combustion result almost entirely from wood consumption for heating in the residential sector. Emissions declined slightly between 1993 and 1994 as the amount of wood consumed in the residential sector declined for the second consecutive year. Methane emissions are the result of incomplete combustion, and wood used in the residential sector is typically consumed in woodstoves and fireplaces, resulting in much less efficient combustion than fuels burned in an industrial or utility boiler. Thus, while the residential sector consumes less than one-third the amount of wood consumed in the industrial sector, residential methane emissions are some 30 times higher than emissions from the industrial sector.

There is, however, considerable uncertainty associated with this estimate. ${ }^{34}$ Estimating wood combustion in the residential sector is difficult, given that the universe of consumers is large and heterogeneous and that wood may be obtained from sources outside the commercial economy. The EIA scales estimated residential wood consumption to heating degree-days, assuming that consumption increases as individuals need to heat their homes. ${ }^{35}$ This method may not accurately capture changes in wood's share of the home heating market.

The importance of emissions from residential wood consumption is underscored by the growth in methane emissions from 1994 to 1995 due to an estimated recovery in residential wood fuel consumption of just above 10 percent. Overall methane emissions from stationary combustion grew by 9.4 percent to 475,000 metric. tons in 1995. Nearly all of this growth is attributed to emissions from residential wood combustion which increased from 368,000 metric tons in 1994 to 409,000 metric tons in 1995 (Table 19). Much smaller growth occurred in methane emissions from the combustion of natural gas in the industrial sector. The only area of decline in emissions from stationary combustion was emissions from the combustion of fuel oil, possibly reflecting a move toward natural gas as an industrial and utility energy source.

\section{Mobile Combustion}

\begin{tabular}{|c|c|}
\hline \multicolumn{2}{|c|}{$\begin{array}{l}\text { U.S. Methane Emissions from Mobile } \\
\text { Combustion, 1990-1994 }\end{array}$} \\
\hline $\begin{array}{l}\text { Estimated } 1994 \text { Emissions } \\
\text { (Thousand Metric Tons Methane) }\end{array}$ & 239 \\
\hline $\begin{array}{l}\text { Change Compared to } 1993 \\
\text { (Thousand Metric Tons Methane) }\end{array}$ & -6 \\
\hline Change from 1993 (Percent) & -2.4 \\
\hline $\begin{array}{l}\text { Change Compared to } 1990 \\
\text { (Thousand Metric Tons Methane) }\end{array}$ & -34 \\
\hline Change from 1990 (Percent) & -12.5 \\
\hline
\end{tabular}

Methane emissions from mobile combustion declined moderately from 239,000 metric tons in 1994 to 230,000 metric tons in 1995 (Table 20). The decrease in emissions from passenger cars was responsible for all of this reduction. Methane emissions from U.S. passenger cars are largely a function of the emissions control technology employed. Over time, the efficiency of catalytic converters in reducing methane emissions has improved. Thus, newer vehicles have lower emissions than older vehicles. As older vehicles leave the fleet and are replaced by new vehicles, overall emissions decline. Between 1988 and 1994, emissions from passenger cars declined each year, from a high of 173,000 metric tons of methane to the most recent 115,000 metric tons of methane. This trend can be expected to continue for the near future.

\footnotetext{
${ }^{34}$ For discussion, see Appendix $C$.

${ }^{35}$ For a more extensive discussion of the method used to estimate residential wood consumption, see Appendix A.
} 


\section{Waste Management}

\section{Landfills}

\begin{tabular}{|c|c|}
\hline \multicolumn{2}{|c|}{$\begin{array}{l}\text { U.S. Methane Emissions from Landfills, } \\
\text { 1990-1994 }\end{array}$} \\
\hline $\begin{array}{l}\text { Estimated } 1994 \text { Emissions } \\
\text { (Million Metric Tons Methane) }\end{array}$ & 10.18 \\
\hline $\begin{array}{l}\text { Change Compared to } 1993 \\
\text { (Million Metric Tons Methane) }\end{array}$ & -0.25 \\
\hline Change from 1993 (Percent) & -2.4 \\
\hline $\begin{array}{l}\text { Change Compared to } 1990 \\
\text { (Million Metric Tons Methane) }\end{array}$ & -0.63 \\
\hline Change from 1990 (Percent) & -5.9 \\
\hline
\end{tabular}

A continuing decline in the annual volume of waste being landfilled, combined with a steady increase in methane recovery, has led to a significant reduction in the level of U.S. methane emissions over the past 5 years (Table 21). While the volume of waste generated grew by about 10 percent between 1990 and 1994, the volume of waste being landfilled declined by some 20 percent. According to the EPA's Office of Solid Waste, the share of municipal solid waste generated that eventually found its way into landfills declined from 82 percent in 1990 to only 61 percent in 1994 (see Appendix A). ${ }^{36}$ This decline is largely a function of the rapid spread of curbside recycling programs, which served 21 million Americans in 1989 and 101 million citizens in 1993. According to Biocycle magazine, some 23 percent of waste generated in the United States is now recycled (Figure 8). However, the rapid growth in curbside.recycling may moderate as municipalities grow concerned about program costs and the economically viable market reaches its saturation point. ${ }^{37}$ Whether the annual growth in recycling will continue to offset the 2percent yearly growth in waste generation remains to be seen.

The volume of methane recovered at landfills also grew substantially between 1990 and 1994. In 1990, approximately 940,000 metric tons of methane was recovered for energy use, and an additional 300,000 metric tons of methane was recovered and flared. In 1994, these numbers had grown to 1.44 million metric tons and 600,000 metric tons, respectively, eliminating more than
2 million metric tons of potential emissions. Regulations implemented by the EPA during 1996 require all landfills with more than 2.5 million metric tons of waste in place and annual emissions of nonmethane organic compounds exceeding 50 metric tons to collect and combust (use or flare) their landfill gas. These New Source Performance Standards (NSPS) emissions guidelines will affect about 300 of the Nation's largest landfills and should result in decreased methane emissions.

While the volume of methane recovered will likely rise, its future disposition is uncertain. About two-thirds of landfills that use recovered methane for energy burn it to generate electricity, and the remainder sell it to enduse customers or distribution companies via pipeline. Thus, the economics of landfill gas-to-energy projects are largely driven by wholesale electricity prices. With the pace of deregulation and restructuring in the electric power industry increasing, the future of wholesale electricity prices is less predictable.

Figure 8. U.S. Solid Waste Generated and Landfilled, 1988-1994

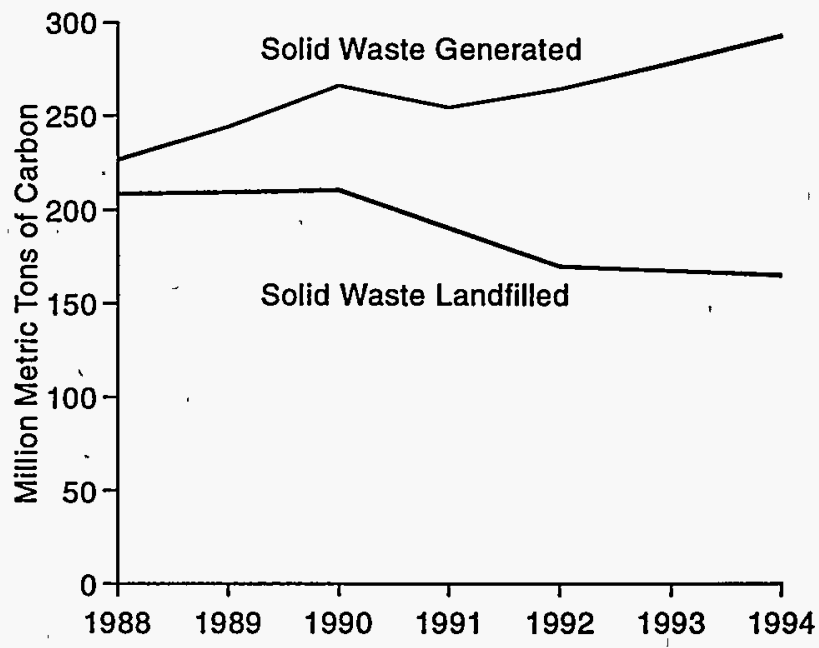

Sources: Franklin Associates, Ltd., Characterization of Municipal Solid Waste in the United States (annual updates prepared for the U.S. Environmental Protection Agency, Office of Solid Waste and Emergency Response), and Biocycle, "Nationwide Survey: The State of Garbage in America" (various years).

Landfill gas-to-energy projects may be eligible for Federal tax credits, pursuant to the "Section 29" tax credit for alternative energy sources. This credit was recently expanded to include all landfill gas projects in place by December 31, 1996, and operating by June 30, 1998.

\footnotetext{
${ }^{36}$ Personal communication, Allen Geswine, U.S. Environmental Protection Agency, Office of Solid Waste (April 17, 1996).

37"Nationwide Survey: The State of Garbage in America," Biocycle (April 1995), pp. 54-63.
} 


\section{Domestic and Commercial Wastewater Treatment}

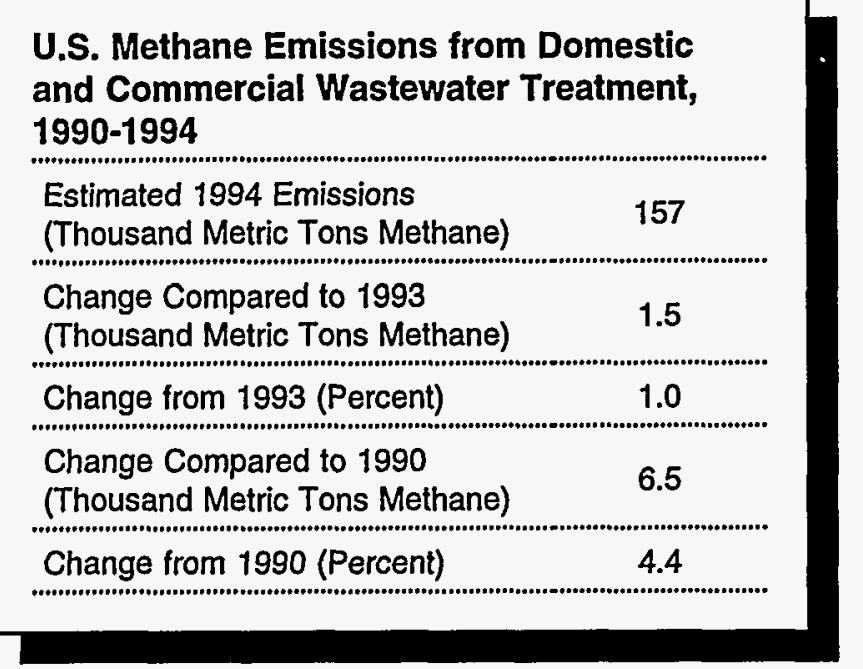

Methane emissions from domestic and commercial wastewater treatment continued their slow but steady increase in 1994, rising from just over 155,000 metric tons in 1993 to almost 157,000 metric ton in 1994 . Because the growth in estimated emissions is driven by increases in U.S. population, emissions can be expected to rise by about 1 percent annually for the foreseeable future. Methane emissions from this source were just over 158,000 metric tons in 1995.

\section{Agricultural Sources}

Methane emissions from agricultural sources totaled 9.1 million metric tons in 1994, about 30 percent of all U.S. anthropogenic methane emissions. There are two major agricultural sources of methane, both of which can be traced to the management of domesticated livestock. The first, enteric fermentation, occurs when carbohydrates are broken down in the digestive track of herbivores such as cattle, sheep, and goats. As microorganisms in the forestomach (rumen) of these animals assist in the digestion of the large quantities of cellulose found in plant material, they produce methane. Nearly all (90 percent) of this methane is released as part of normal animal respiration and eructation. The remainder is released as flatus. The second source is the solid waste of domesticated animals. As solid waste decomposes under anaerobic conditions methane is produced. Together, these two sources accounted for an estimated 8.5 million metric tons of methane emissions in 1994 . Of that total, 5.6 million metric tons of methane was emitted through enteric fermentation and the remainder from solid wastes accumulated at farm facilities. The

\section{Industrial Wastewater}

This report does not present estimates of methane emissions from industrial wastewater treatment due to a lack of reliable data on waste treatment methods and volumes of wastewater generated for several important industries. Methane generation from wastewater is the result of anaerobic decomposition of organic matter in the wastewater. Thus, emissions are driven by the share of organic matter in the wastewater stream and the method under which it decomposes. Most industrial wastewater has a low organic content. However, wastewater from the pulp and paper industry and the food and beverage industry (particularly breweries) has a very high organic content. Currently, the EPA's Office of Research and Development is conducting research into emissions from industrial sources. Depending on the treatment methods employed in each industry, emissions from industrial wastewater might amount to as much as several million metric tons of methane annually.*

*S.A. Thorneloe, "Methane from Waste Water Treatment," in International IPCC Workshop Proceedings: Methane and Nitrous Oxide Methods in National Emissions Inventories and Options for Control (Bilthoven, Netherlands: RIVM, 1993), pp. 115-130.

minor sources of agricultural methane emissions, rice cultivation and burning of crop residues, added an additional 600,000 metric tons to the emissions totals.

\section{Enteric Fermentation in Domesticated Animals}

U.S. Methane Emissions from Enteric
Fermentation in Domesticated Animals,
$1990-1994$
Estimated 1994 Emissions
(Million Metric Tons Methane)
(Mhange Compared to 1993
(Million Metric Tons Methane)


Methane emissions from enteric fermentation in domesticated animals are estimated at 5.62 million metric tons in 1994, up by nearly 3 percent from 1993 and by nearly 10 percent from 1990 (Table 22). These increases reflect the continuing rise of beef cattle populations. The increases in population were accompanied by growth in the average size of the animals, as measured by their live weight at slaughter (see Appendix A). The growth in beef cattle sizes in 1994 came after a slight decrease in animal sizes in 1993. The 1993 decrease was the first decline in beef cattle sizes in over a decade. While the population of dairy cattle did not rise along with beef cattle in 1994, emissions per animal did increase, as milk production (and hence food energy consumption) rose. $^{38}$

Average cattle size in 1995 was slightly below that for 1994 but still above 1993 levels. Thus, small increases in population were offset by decreases in estimated emissions per animal. In contrast, populations of dairy cattle declined slightly in 1995, but levels of milk production per animal increased again over the previous year. The net result of these countervailing forces was that emissions for 1995 remained stable compared to 1994 at 5.62 million metric tons.

\section{Solid Waste of Domesticated Animals}

\begin{tabular}{|c|c|}
\hline \multicolumn{2}{|c|}{$\begin{array}{l}\text { U.S. Methane Emissions from Solid Waste } \\
\text { of Domesticated Animals, 1990-1994 }\end{array}$} \\
\hline $\begin{array}{l}\text { Estimated } 1994 \text { Emissions } \\
\text { (Million Metric Tons Methane) }\end{array}$ & 2.88 \\
\hline $\begin{array}{l}\text { Change Compared to } 1993 \\
\text { (Million Metric Tons Methane) }\end{array}$ & 0.07 \\
\hline Change from 1993 (Percent) & 2.5 \\
\hline $\begin{array}{l}\text { Change Compared to } 1990 \\
\text { (Million Metric Tons Methane) }\end{array}$ & 0.25 \\
\hline Change from 1990 (Percent) & 9.7 \\
\hline
\end{tabular}

\section{New Method for Estimating Methane Emissions from Dairy Cattle Waste}

In its November 1995 publication, Inventory of U.S. Greenhouse Gas Emissions and Sinks, 1990-1994, the EPA identified six States-Arizona, Florida, Nevada, North Carolina, North Dakota, and Texas-where methods for handling the solid waste of dairy cattle changed between 1991 and 1992. In general, this shift moved dairy cattle waste into anaerobic lagoons from other management systems. Because anaerobic lagoons are particularly well suited for methane production, waste moved into lagoons produces 5 to 90 times the methane it would produce in another management system. To capture this shift, the EIA revised its method for estimating methane emissions from dairy cattle. For the period 1990 to 1995, emissions from dairy cattle in the six States listed above were calculated separately from emissions for all other cattle, and the subtotals were then aggregated (for a more detailed discussion of estimation methods, see Appendix A). These estimates were made using the new data on waste management systems provided by the EPA. The new estimation technique raised emissions estimates for dairy cattle by just under 10 percent and overall estimates of methane emissions from the solid waste. of domesticated livestock by about 3 percent over the estimates produced with the method used in last year's edition of Emissions of Greenhouse Gases in the United States. A comparison of estimates for the period 1990 to 1995 appears below.

Comparison of Estimates of Methane Emissions from the Solid Waste of Domesticated Animals (Thousand Metric Tons)

\begin{tabular}{|c|c|c|c|c|c|c|}
\hline Estimate & 1990 & 1991 & 1992 & 1993 & 1994 & 1995 \\
\hline Dairy Cattle: Last Year & 957 & 968 & 963 & 953 & 968 & 960 \\
\hline Dairy Cattle: Current ...... & 973 & 980 & 1,042 & 1,039 & 1,061 & 1,054 \\
\hline All Animals: Last Year . & 2,615 & 2,717 & 2,730 & 2,727 & 2,792 & 2,912 \\
\hline All Animals: Current & 2,630 & 2,729 & 2,810 & 2,814 & 2,885 & 3,007 \\
\hline
\end{tabular}

\footnotetext{
${ }^{38}$ For more information on the role animal size and productivity play in emissions estimates, see Appendix A.
} 
Methane emissions from the solid waste of domesticated animals were 2.9 million metric tons in 1994, up from 2.8 million metric tons in 1993, and well above the 2.6 million metric tons emitted from this source in 1990 (Table 23). Just over one-third of emissions from this source can be traced to dairy cattle, and another onethird is attributed to swine sold for human consumption. Nearly 75 percent of the increase in methane emissions between 1990 and 1994 can be traced to these two animal groups.

Due to growth in their population, emissions from market swine grew by 11 percent between 1990 and 1994. During that same period, emissions from dairy cattle grew by 9 percent. About one-half of the increase in estimated emissions from dairy cattle was the result of greater animal size and productivity. The remaining portion of the rise in emissions from dairy cattle is traced to a shift in the method used for handling the solid waste of dairy cattle in six States: Arizona, Florida, Nevada, North Carolina, North Dakota, and Texas. Waste management techniques in these States shifted toward liquid systems, especially anaerobic lagoons. Solid waste managed in anaerobic lagoons realizes a much larger share of its maximum potential methane production than waste managed in any other manner.

The growth in market swine populations accelerated in 1995, growing by 13 percent. This will further increase methane emissions from the solid waste of domesticated livestock. However, the size, population, and productivity of other animals appears to have stabilized, restricting emissions growth to swine.

\section{Rice Cultivation}

U.S. Methane Emissions from
Rice Cultivation, 1990 -1994
Estimated 1994 Emissions
(Thousand Metric Tons Methane)
Change Compared to 1993
(Thousand Metric Tons Methane)

As organic material decomposes under anaerobic conditions in flooded rice fields, methane is produced. ${ }^{39}$ Methane emissions from flooded rice fields are estimated at 460,000 metric tons for 1994, up 15 percent from the levels of both 1990 and 1993 (Table 16). This growth was the result of highly favorable growing conditions across all the rice-producing States. Hectares harvested grew by 17 percent between 1993 and 1994, from 1.24 million hectares to 1.46 million hectares, the highest levels seen since the early 1980s (Table 24).

In 1995, methane emissions from U.S. rice fields declined to 430,000 metric tons as each of the riceproducing States experienced a decline in hectares harvested. The total area harvested moved back toward levels routinely seen over the past decade, about 1.35 million hectares.

\section{Burning of Crop Residues}

\begin{tabular}{l}
\hline U.S. Methane Emissions from \\
Burning of Crop Residues, 1990-1994 \\
Estimated 1994 Emissions \\
(Thousand Metric Tons Methane) \\
Change Compared to 1993 \\
(Thousand Metric Tons Methane)
\end{tabular}

In 1994, estimated methane emissions from the burning of crop residues reached their highest level in over a decade, as moderate summer temperatures and precipitation levels in the Midwest led to record levels of soybean and corn production. Corn production increased by 44 percent from 1993 to 1994 , to 336 million metric tons, while soybean production soared by 38 percent to 69 million metric tons.

In 1995, corn production declined sharply to 258 million metric tons and soybean production receded to 58 million metric tons. As a result, preliminary estimates of 1995 methane emissions from crop residue burning show a drop to 120,000 metric tons, 10,000 metric tons below 1990 levels (Table 16).

\footnotetext{
${ }^{39}$ For further explanation of how methane is released to the atmosphere from flooded rice fields, see Appendix A.
} 


\section{Industrial Processes}

\section{Chemical Production}

\begin{tabular}{|c|c|}
\hline \multicolumn{2}{|l|}{$\begin{array}{l}\text { U.S. Methane Emissions from } \\
\text { Chemical Production, 1990-1994 }\end{array}$} \\
\hline $\begin{array}{l}\text { Estimated } 1994 \text { Emissions } \\
\text { (Thousand Metric Tons Methane) }\end{array}$ & 72 \\
\hline $\begin{array}{l}\text { Change Compared to } 1993 \\
\text { (Thousand Metric Tons Methane) }\end{array}$ & 6 \\
\hline Change from 1993 (Percent) & 9.6 \\
\hline $\begin{array}{l}\text { Change Compared to } 1990 \\
\text { (Thousand Metric Tons Methane) }\end{array}$ & 17 \\
\hline Change from 1990 (Percent) & 29.8 \\
\hline
\end{tabular}

During 1994, methane emissions from chemical production continued their slow but steady growth. Levels of methane emissions from chemical production largely reflect more general trends in the national economy. The growth in emissions from chemical production slowed during the 1991 recession, although emissions levels did not decline. Following the recession, emissions from chemical production grew rapidly, rising from 57,000 metric tons in 1991 to 72,000 metric tons in 1994, an annual growth rate of more than 8 percent. In 1995, emissions from chemical production remained unchanged at 72,000 metric tons (Table 25).

A significant portion (60 percent) of the growth in methane emissions from chemical production between 1991 and 1994 can be attributed to an increase in emissions from production of ethylene and styrene. Production of ethylene grew by more than 20 percent during the 1991-1994 time period, and production of styrene grew by nearly 40 percent. To a large extent, the production of styrene drives the production of ethylene, because ethylene is one of the principal feedstocks in producing styrene. Styrene is used to produce polystyrene, a transparent, hard solid with many popular applications such as refrigerator doors, air conditioner cases, clock and radio cases, toys, foam packaging, and water coolers. In 1995, production of styrene leveled off, and production of ethylene declined slightly.

\section{Iron and Steel Production}

U.S. Methane Emissions from
Iron and Steel Production, 1990-1994
Estimated 1994 Emissions
(Thou'sand Metric Tons Methane)
Change Compared to 1993
(Thousand Metric Tons Methane)
Change from 1993 (Percent)
Change Compared to 1990
(Thousand Metric Tons Methane)
Change from 1990 (Percent)

Like methane emissions from chemical production, levels of methane emissions from iron and steel production are largely linked to rates of economic activity: Emissions from iron and steel production reached a peak of 64,000 metric tons in 1989 but then declined by 16 percent to 54,000 metric tons during the 1991 recession (Table 25). While emissions from iron and steel production have yet to return to their peak level, they have grown slowly since 1991, reaching 61,000 metric tons in 1995. 
Table 16. U.S. Methane Emissions from Anthropogenic Sources, 1988-1995 (Million Metric Tons of Methane)

\begin{tabular}{|c|c|c|c|c|c|c|c|c|}
\hline Source & 1988 & 1989 & 1990 & 1991 & 1992 & 1993 & 1994 & 1995 \\
\hline \multicolumn{9}{|l|}{ Energy Sources } \\
\hline Coal Mining & 4.25 & 4.33 & 4.64 & 4.40 & 4.31 & 3.51 & 3.85 & NA \\
\hline Oil and Gas $\ldots \ldots \ldots \ldots \ldots \ldots$ & 6.47 & 6.48 & 6.59 & 6.73 & 6.78 & 6.78 & 6.89 & 6.60 \\
\hline Stationary Combustion & 0.66 & 0.69 & 0.46 & 0.48 & 0.51 & 0.44 & 0.43 & 0.48 \\
\hline Mobile Sources $\ldots \ldots \ldots \ldots \ldots \ldots$ & 0.30 & 0.29 & 0.27 & 0.26 & 0.26 & 0.24 & 0.24 & 0.23 \\
\hline Total Energy Sources & 11.69 & 11.79 & 11.96 & 11.87 & 11.86 & 10.97 & 11.42 & NA \\
\hline \multicolumn{9}{|l|}{ Waste Management } \\
\hline Landfills & 10.64 & 10.65 & 10.81 & 10.72 & 10.60 & 10.43 & 10.18 & NA \\
\hline Waste Water Treatment & 0.15 & 0.15 & 0.15 & 0.15 & 0.15 & 0.16 & 0.16 & 0.16 \\
\hline Total Waste Management & 10.79 & 10.80 & 10.96 & 10.88 & 10.76 & 10.58 & 10.34 & NA \\
\hline \multicolumn{9}{|l|}{ Agricultural Sources } \\
\hline Ruminant Animals .... & 5.10 & 5.08 & 5.13 & 5.31 & 5.39 & 5.46 & 5.62 & 5.62 \\
\hline Animal Waste ..... & 2.64 & 2.60 & 2.63 & 2.73 & 2.81 & 2.81 & 2.88 & 3.01 \\
\hline Rice Paddies $\ldots \ldots \ldots \ldots \ldots \ldots$. & 0.41 & 0.38 & 0.40 & 0.39 & 0.44 & 0.40 & 0.46 & 0.43 \\
\hline Crop Residue Burning . . . . . . . & 0.10 & 0.12 & 0.13 & 0.12 & 0.14 & 0.11 & 0.15 & 0.12 \\
\hline Total Agricultural Sources . . . . . . . . . & 8.24 & 8.18 & 8.29 & 8.55 & 8.77 & 8.79 & 9.11 & 9.18 \\
\hline Industrial Processes $\ldots \ldots \ldots \ldots \ldots$ & 0.12 & 0.12 & 0.12 & 0.11 & 0.12 & 0.12 & 0.13 & 0.13 \\
\hline Total $\ldots \ldots \ldots \ldots \ldots \ldots \ldots \ldots$ & 30.84 & 30.89 & 31.34 & 31.40 & 31.51 & 30.47 & 30.99 & NA \\
\hline
\end{tabular}

$\mathrm{NA}=$ not available.

Notes: Data in this table are revised from the data contained in the previous EIA report, Emissions of Greenhouse Gases in the United States 1987-1994, DOE/EIA-0573(87-94) (Washington, DC, October 1995). Totals may not equal sum of components due to independent rounding.

Sources: EIA estimates presented in this chapter. Crop residue burning-U.S. Department of Agriculture, National Agricultural Statistics Service, Crop Production annual reports. Emissions calculations based on Intergovernmental Panel on Climate Change, Greenhouse Gas Inventory Reference Manual, IPCC Guidelines for National Greenhouse Gas Inventories, Vol. 3 (Paris, France, 1995), pp. 4.50-4.62. 
Table 17. U.S. Methane Emissions from Oil and Gas Operations, 1988-1995 (Million Metric Tons of Methane)

\begin{tabular}{|c|c|c|c|c|c|c|c|c|}
\hline Source & 1988 & 1989 & 1990 & 1991 & 1992 & 1993 & 1994 & P1995 \\
\hline \multicolumn{9}{|l|}{ Oil and Gas Production } \\
\hline Natural Gas Weliheads . . . . . . . . & 0.28 & 0.28 & 0.29 & 0.30 & 0.30 & 0.30 & 0.31 & 0.31 \\
\hline Oil Wells $\ldots \ldots \ldots \ldots \ldots \ldots \ldots$ & 0.05 & 0.04 & 0.04 & 0.04 & 0.04 & 0.04 & 0.04 & 0.04 \\
\hline Gathering Pipelines . . . . . . . . . . & 1.10 & 1.08 & 1.07 & 1.03 & 1.03 & 0.92 & 0.92 & 0.92 \\
\hline Gas Processing Plants . . . . . . . . & 0.55 & 0.55 & 0.62 & 0.69 & 0.68 & 0.70 & 0.70 & 0.70 \\
\hline Heaters, Separators, Dehydrators . . & 0.17 & 0.17 & 0.17 & 0.17 & 0.17 & 0.18 & 0.19 & 0.19 \\
\hline Total $\ldots \ldots \ldots \ldots \ldots \ldots$ & 2.13 & 2.12 & 2.19 & 2.23 & 2.23 & 2.15 & 2.16 & 2.17 \\
\hline Gas Venting . . . . . . . . . . . & 0.77 & 0.77 & 0.75 & 0.81 & 0.83 & 0.97 & 1.01 & 0.68 \\
\hline Gas Transmission and Distribution ... & 3.48 & 3.51 & 3.56 & 3.60 & 3.64 & 3.57 & 3.64 & 3.67 \\
\hline Oil Refining and Transportation ..... & 0.08 & 0.08 & 0.08 & 0.08 & 0.08 & 0.08 & 0.09 & 0.09 \\
\hline Total $\ldots \ldots \ldots \ldots \ldots \ldots \ldots$ & 6.47 & 6.48 & 6.59 & 6.73 & 6.78 & 6.78 & 6.89 & 6.60 \\
\hline
\end{tabular}

$P=$ preliminary data.

Notes: Data in this table are revised from the data contained in the previous EIA report, Emissions of Greenhouse Gases in the United States 1987-1994, DOE/EIA-0573(87-94) (Washington, DC, October 1995). Totals may not equal sum of components due to independent rounding.

Sources: M.R. Harrison and R.M. Cowgill, Tier 2 Summary of Methane Emissions from the Natural Gas Industry, Draft Final Report Prepared for the Gas Research Institute and the U.S. Environmental Protection Agency (Washington, DC, January 1996); World Oil (February issue, various years); American Gas Association, Gas Facts (various years); Energy Information Administration, Natural Gas Annual, DOE/EIA-0131 (various years); Radian Corporation, Global Emissions of Methane from Petroleum Sources (February 1992); Energy Information Administration, Annual Energy Review 1995, DOE/EIA-0384(95) (Washington, DC, July 1996); Energy Information Administration, Petroleum Supply Annual, DOE/ElA-0340 (Washington, DC, various years).

Table 18. U.S. Methane Emissions from Coal Mining and Post-Mining Activities, 1988-1995 (Million Metric Tons of Methane)

\begin{tabular}{|c|c|c|c|c|c|c|c|c|}
\hline Source & 1988 & 1989 & 1990 & 1991 & 1992 & 1993 & 1994 & 1995 \\
\hline \multicolumn{9}{|l|}{ Surface Mining } \\
\hline Mining & 0.40 & 0.41 & 0.43 & 0.42 & 0.42 & 0.42 & 0.45 & NA \\
\hline Post-Mining & 0.03 & 0.04 & 0.04 & 0.04 & 0.04 & 0.04 & 0.04 & NA \\
\hline \multicolumn{9}{|l|}{ Underground Mining } \\
\hline Ventilation (Gassy Mines) & 2.04 & 1.98 & 2.13 & 2.05 & 2.12 & 1.82 & 2.02 & NA \\
\hline Ventilation (Nongassy Mines) & 0.02 & 0.03 & 0.03 & 0.03 & 0.02 & 0.03 & 0.03 & NA \\
\hline Degasification . & 1.43 & 1.52 & 1.63 & 1.51 & 1.48 & 1.16 & 1.19 & NA \\
\hline Post-Mining & 0.58 & 0.59 & 0.64 & 0.61 & 0.61 & 0.53 & 0.60 & NA \\
\hline Methane Recovery for Energy $(-)$ & 0.25 & 0.25 & 0.25 & 0.25 & 0.37 & 0.48 & 0.48 & NA \\
\hline Net Emissions $\ldots \ldots \ldots \ldots \ldots \ldots \ldots$ & 4.25 & 4.33 & 4.64 & 4.40 & 4.31 & 3.51 & 3.85 & NA \\
\hline
\end{tabular}

$N A=$ not available.

Notes: Data in this table are revised from the data contained in the previous EIA report, Emissions of Greenhouse Gases in the United States 1987-1994, DOE/EIA-0573(87-94) (Washington, DC, October 1995). Totals may not equal sum of components due to independent rounding.

Sources: Coal production numbers from Energy Information Administration, Coal Production, DOE/EIA-0118 (Washington, DC, various years), and Coal Industry Annual, DOE/EIA-0584(94) and (95) (Washington, DC, 1994 and 1995). Methane recovery rates from U.S Environmental Protection Agency, Office of Air and Radiation, Anthropogenic Methane Emissions in the United States: Estimates for 1990, Report to Congress (Washington, DC, April 1993), pp. 3-19-3-24; and Identifying Opportunities for Methane Recovery at U.S. Coal Mines: Draft Profiles of Selected Gassy Underground Coal Mines (Washington, DC, September 1994), pp. 6-6-6-8. Ventilation data for 1985, 1988, 1990, and 1993 provided by G. Finfinger, U.S. Department of the Interior, Bureau of Mines, Pittsburgh Research Center. 
Table 19. U.S. Methane Emissions from Stationary Combustion Sources, 1988-1995 (Thousand Metric Tons of Methane)

\begin{tabular}{|c|c|c|c|c|c|c|c|c|}
\hline Source & 1988 & 1989 & 1990 & 1991 & 1992 & 1993 & 1994 & 1995 \\
\hline \multicolumn{9}{|l|}{ Residential } \\
\hline Coal..$\ldots \ldots \ldots \ldots$ & • & * & * & * & • & - & * & - \\
\hline Distillate Fuel $\ldots . . . \ldots$. & 6 & 5 & 4 & 4 & 5 & 5 & 5 & 5 \\
\hline Natural Gas $\ldots . \ldots \ldots$ & 5 & 5 & 5 & 5 & 5 & 5 & 5 & 5 \\
\hline $\operatorname{LPG} \ldots \ldots \ldots \ldots \ldots$ & * & - & - & - & - & - & * & - \\
\hline Wood...$\ldots \ldots \ldots$ & 600 & 629 & 398 & 420 & 442 & 376 & 368 & 409 \\
\hline Total ............ & 611 & 640 & 408 & 430 & 452 & 386 & 379 & 419 \\
\hline \multicolumn{9}{|l|}{ Commercial } \\
\hline Coal $\ldots \ldots \ldots \ldots \ldots$ & 1 & 1 & 1 & 1 & 1 & 1 & 1 & 1 \\
\hline Fuel Oil ............. & 1 & 1 & 1 & 1 & 1 & 1 & 1 & 1 \\
\hline Natural Gas . . . . . . . . & 3 & 4 & 3 & 4 & 4 & 4 & 4 & 4 \\
\hline$L P G, \ldots \ldots \ldots \ldots \ldots$ & * & * & - & * & • & * & * & - \\
\hline 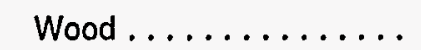 & * & * & * & - & • & - & * & * \\
\hline Total ............. & 6 & 5 & 5 & 5 & 5 & 6 & 6 & 6 \\
\hline \multicolumn{9}{|l|}{ Industrial } \\
\hline$\ldots \ldots \ldots$ & 7 & 7 & 7 & 7 & 6 & 6 & 6 & 6 \\
\hline Fuel Oil ............ & 2 & 1 & 1 & 1 & 1 & 2 & 1 & 1 \\
\hline Natural Gas ......... & 11 & 12 & 13 & 13 & 13 & 14 & 14 & 15 \\
\hline LPG ............. & 3 & 2 & 2 & 3 & 3 & 3 & 3 & 3 \\
\hline Wood .............. & 13 & 12 & 12 & 12 & 13 & 13 & 13 & 13 \\
\hline Total ............ & 36 & 35 & 36 & 35 & 36 & 37 & 38 & 39 \\
\hline \multicolumn{9}{|l|}{ Electric Utility } \\
\hline Coal $\ldots \ldots \ldots \ldots \ldots$ & 10 & 10 & 10 & 10 & 10 & 11 & 11 & 11 \\
\hline Fuel Oil ............ & 1 & 1 & 1 & 1 & 1 & 1 & 1 & 0 \\
\hline Natural Gas . . & * & * & - & * & * & - & - & - \\
\hline Wood .............. & * & * & * & * & * & * & • & * \\
\hline Total ............ & 12 & 12 & 11 & 11 & 11 & 12 & 12 & 12 \\
\hline \multicolumn{9}{|l|}{ Total All Fuels } \\
\hline Coal ........ & 18 & 18 & 18 & 18 & 18 & 18 & 18 & 18 \\
\hline Fuel Oil ..... & 9 & 9 & 7 & 7 & 7 & 8 & 7 & 7 \\
\hline Natural Gas ......... & 20 & 21 & 21 & 22 & 22 & 23 & 24 & 25 \\
\hline LPG ............. & 3 & 3 & 3 & 3 & 3 & 3 & 3 & 3 \\
\hline Wood .............. & 613 & 642 & 411 & 433 & 455 & 389 & 382 & 422 \\
\hline Total .. & 664 & 693 & 460 & 482 & 505 & 44,1 & 434 & 475 \\
\hline
\end{tabular}

*Less than 500 metric tons of methane.

${ }^{\mathrm{a}}$ Estimate. Underlying energy data not available.

Notes: Data in this table are revised from the data contained in the previous EIA report, Emissions of Greenhouse Gases in the United States 1987-1994, DOE/EIA-0573(87-94) (Washington, DC, October 1995). Totals may not equal sum of components due to independent rounding.

Sources: U.S. Environmental Protection Agency, Office of Air Quality Planning and Standards, Compilation of Air Pollutant Emission Factors, AP-42 Supplement D (Research Triangle Park, NC, September 1995). Energy Information Administration, State Energy Data Report 1994, DOE/EIA-0214(94) (Washington, DC, July 1996); Monthly Energy Review, DOE/ElA-0035(96/07) (Washington, DC, July 1996); and Annual Energy Review 1995, DOE/EIA-0384(95) (Washington, DC, July 1996), p. 267. 
Table 20. U.S. Methane Emissions from Mobile Sources, 1988-1995 (Thousand Metric Tons of Methane)

\begin{tabular}{|c|c|c|c|c|c|c|c|c|}
\hline Item & 1988 & 1989 & 1990 & 1991 & 1992 & 1993 & 1994 & P1995 \\
\hline \multicolumn{9}{|l|}{ Motor Vehicles } \\
\hline Passenger Cars ....... & 173 & 162 & 151 & 143 & 139 & 122 & 115 & 112 \\
\hline Buses $\ldots \ldots \ldots$ & 1 & 1 & 1 & 1 & 1 & 1 & 1 & 0 \\
\hline Motorcycles ......... & 5 & 5 & 5 & 5 & 5 & 5 & 5 & 5 \\
\hline Light-Duty Trucks . . . . . & 68 & 66 & 64 & 62 & 62 & 64 & 64 & 57 \\
\hline Other Trucks . . . . . . . & 23 & 24 & 24 & 24 & 25 & 26 & 27 & 28 \\
\hline Total $\ldots . . . \ldots \ldots$ & 270 & 259 & 246 & 235 & 231 & 218 & 212 & 202 \\
\hline Other Transport $\ldots \ldots$ & 27 & 28 & 27 & 27 & 28 & 27 & 27 & 27 \\
\hline Total Transport . . . . . . . & 297 & 287 & 273 & 262 & 260 & 245 & 239 & 229 \\
\hline
\end{tabular}

$P=$ preliminary data.

Sources: Calculations based on vehicle miles traveled from U.S. Department of Transportation, Federal Highway Statistics, various years, Table VM-1. Vehicle emissions coefficients from Intergovernmental Panel on Climate Change, Greenhouse Gas Inventory Reference Manual, IPCC Guidelines for National Greenhouse Gas Inventories, Vol. 3 (Paris, France, 1995), pp. 1.72-1.82. Distribution of passenger car and light duty truck fleet model years for 1983,1985,1988,1991, and 1994 according to data in the Energy Information Administration's "Residential Transportation Energy Consumption Surveys" for those years. Distribution for passenger cars and light duty trucks in other years computed by interpolation. Distribution of bus and other truck fleet according to model year computed assuming 10-percent attrition per annum of pre-1983 fleet for each year after 1984 .

Table 21. U.S. Methane Emissions from Anaerobic Decomposition in Landfills, 1988-1995 (Million Metric Tons of Methane)

\begin{tabular}{c|r|r|r|r|r|r|r|c}
\hline Type & 1988 & 1989 & 1990 & 1991 & 1992 & 1993 & 1994 & 1995 \\
\hline Gross Emissions . . . . . . . . & 11.6 & 11.8 & 12.1 & 12.2 & 12.3 & 12.3 & 12.2 & NA \\
Methane Recovery (Energy) . . . & 0.7 & 0.9 & 0.9 & 1.1 & 1.2 & 1.3 & 1.4 & NA \\
Methane Assumed Flared . . . . . & 0.3 & 0.3 & 0.3 & 0.4 & 0.5 & 0.6 & 0.6 & NA \\
Net Emissions ............ & 10.6 & 10.7 & 10.8 & 10.7 & 10.6 & 10.4 & 10.2 & NA \\
\hline
\end{tabular}

$\mathrm{NA}=$ not available.

Note: Data in this table are revised from the data contained in the previous EIA report, Emissions of Greenhouse Gases in the United States 1987-1994, DOE/EIA-0573(87-94) (Washington, DC, October 1995).

Sources: Municipal solid waste landfilled from Franklin Associates, Ltd., Characterization of Municipal Solid Waste in the United States, Annual Updates (prepared for the U.S. Environmental Protection Agency, Municipal Solid and Industrial Solid Waste Division), Personal communication with Marjorie Franklin, Franklin Associates, Lid., May 1994, and Biocycle, Nationwide Survey: The State of Garbage in America 1988-1995. Emissions calculations based on S.A. Thomeloe et al., "Estimate of Methane Emissions from U.S. Landfills," Prepared for the U.S. Environmental Protection Agency, Office of Research and Development, in departmental review (April 1994), and D. Augenstein, "The Greenhouse Effect and U.S. Landfill Methane," Global Environmental Change (December 1992), pp. 311-328. Methane recovered and flared from S.A. Thorneloe, "Landfill Gas Recovery Utilization-Options and Economics," presented at the Sixteenth Annual Conference by the Institute of Gas Technology on Energy from Biomass and Wastes, Orlando, Florida (March 5, 1992), and J. Pacey, "Methane Recovery from Landfills," presented at the 1995 Greenhouse Gas Emissions and Mitigation Research Symposium, Washington, DC (June 27-29, 1995). 
Table 22. U.S. Methane Emissions from Enteric Fermentation in Domesticated Animals, 1988-1995 (Million Metric Tons of Methane).

\begin{tabular}{|c|c|c|c|c|c|c|c|c|}
\hline Animal Type & 1988 & 1989 & 1990 & 1991 & 1992 & 1993 & 1994 & 1995 \\
\hline Cattle ........... & 4.81 & 4.80 & 4.84 & 5.02 & 5.10 & 5.18 & 5.35 & 5.35 \\
\hline Sheep $: \ldots \ldots \ldots \ldots$ & 0.14 & 0.14 & 0.15 & 0.15 & 0.14 & 0.14 & 0.13 & 0.12 \\
\hline Pigs $\ldots \ldots \ldots \ldots \ldots$ & 0.08 & 0.08 & 0.08 & 0.09 & 0.09 & 0.09 & 0.09 & 0.10 \\
\hline Goats . . . . . . . . . . & 0.02 & 0.02 & 0.02 & 0.02 & 0.02 & 0.02 & 0.02 & 0.02 \\
\hline Horses $\ldots \ldots \ldots \ldots \ldots$ & 0.04 & 0.04 & 0.04 & 0.04 & 0.04 & 0.04 & 0.03 & 0.03 \\
\hline Total . . . . . . . . . . & 5.10 & 5.08 & 5.13 & 5.31 & 5.39 & 5.46 & 5.62 & 5.62 \\
\hline
\end{tabular}

Notes: Data in this table are revised from the data contained in the previous EIA report, Emissions of Greenhouse Gases in the United States 1987-1994, DOE/EIA-0573(87-94) (Washington, DC, October 1995). Totals may not equal sum of components due to independent rounding.

Sources: Cattle, sheep, and pig population data provided by the U.S. Department of Agriculture, National Agricultural Statistics Service, Livestock, Dairy and Poultry Service. Goat and horse population figures extrapolated from U.S. Department of Commerce, Bureau of the Census, Census of Agriculture, 1982, 1987, and 1992. Emissions calculations based on U.S. Environmental Protection Agency, Office of Air and Radiation, Anthropogenic Methane Emissions in the United States: Estimates for 1990 (Washington, DC, April 1993), and P.J. Crutzen, I. Aselmann, and W.S. Seiler, "Methane Production by Domestic Animals, Wild Ruminants, Other Herbivorous Fauna, and Humans," Tellus, Vol. 38B (1986), pp. 271-284.

Table 23. U.S. Methane Emissions from the Solid Waste of Domesticated Animals, 1988-1995 (Thousand Metric Tons of Methane)

\begin{tabular}{|c|c|c|c|c|c|c|c|c|}
\hline Type of Animal & 1988 & 1989 & 1990 & 1991 & 1992 & 1993 & 1994 & 1995 \\
\hline Cattle & 1,211 & 1,203 & 1,222 & 1,244 & 1,314 & 1,317 & 1,349 & 1,343 \\
\hline Beef Cattle $\ldots \ldots \ldots$. . & 245 & 243 & 249 & 264 & 271 & 278 & 288 & 288 \\
\hline Dairy Cattle & 966 & 960 & 973 & 980 & 1,042 & 1,039 & 1,061 & 1,054 \\
\hline Swine $\ldots \ldots \ldots \ldots \ldots$ & 1,261 & 1,223 & 1,234 & 1,306 & 1,312 & 1,308 & 1,343 & 1,467 \\
\hline Market Swine & 876 & 849 & 861 & 912 & 924 & 918 & 958 & 1,080 \\
\hline Breeding Swine & 385 & 374 & .373 & 394 & 388 & 390 & 385 & 387 \\
\hline Poultry $\ldots \ldots \ldots \ldots$ & 150 & 152 & 157 & 161 & 167 & 172 & 178 & 183 \\
\hline Caged Layers . . . . . . . . & 85 & 83 & 83 & 84 & 86 & 88 & 90 & 91 \\
\hline Broilers & 65 & 69 & 73 & 77 & 81 & 84 & 88 & 92 \\
\hline Other Animals $\ldots \ldots \ldots$ & 18 & 18 & 18 & 17 & 17 & 16 & 15 & 15 \\
\hline Sheep $\ldots \ldots \ldots \ldots \ldots$ & 5 & 5 & 5 & 5 & 5 & 5 & 4 & 4 \\
\hline Goats..$\ldots \ldots \ldots \ldots$ & 1 & 1 & 1 & 1 & 1 & 1 & 1 & 1 \\
\hline Horses $\ldots \ldots \ldots \ldots \ldots$ & 13 & 12 & 12 & 11 & 11 & 11 & 10 & 10 \\
\hline Total $\ldots \ldots \ldots \ldots \ldots$ & 2,640 & 2,596 & 2,630 & 2,729 & 2,810 & 2,814 & 2,885 & 3,007 \\
\hline
\end{tabular}

Notes: Data in this table are revised from the data contained in the previous ElA report, Emissions of Greenhouse Gases in the United States 1987-1994, DOE/EIA-0573(87-94) (Washington, DC, October 1995). Totals may not equal sum of components due to independent rounding.

Sources: Population data for horses and goats extrapolated from U.S. Department of Commerce, Bureau of the Census, Census of Agriculture, 1982, 1987, and 1992. Population data for all other animals from U.S. Department of Agriculture, National Agricultural Statistics Service, Livestock, Dairy and Poultry Branch. Typical animal sizes from U.S. Environmental Protection Agency, Office of Air and Radiation, Anthropogenic Methane Emissions in the United States: Estimates for 1990, Report to Congress (Washington, DC, April, 1993). Cattle sizes adjusted by annual slaughter weight from U.S. Department of Agriculture, National Agricultural Statistics Service, Livestock, Dairy and Poultry Branch. Maximum methane production, and waste management systems used from L.M. Safley, M.E. Casada, et al., Global Methane Emissions from Livestock and Poultry Manure (Washington, DC: U.S. Environmental Protection Agency, February 1992), pp. 24-27, and U.S. Environmental Protection Agency, Inventory of U.S. Greenhouse Gas Emissions and Sinks 1990-1994, EPA-230-496-006 (Washington, DC, November 1995), Appendix D. Methane Conversion Factors from Intergovernmental Panel on Climate Change, Greenhouse Gas Inventory Reference Manual, IPCC Guidelines for National Greenhouse Gas Inventories, Vol. 3 (Paris, France, 1995), pp. 4.33-4.41. 
Table 24. Area of Land Harvested for Rice and Estimated U.S. Methane Emissions from Flooded Rice Fields, 1988-1995

\begin{tabular}{|c|c|c|c|c|c|c|c|c|}
\hline Item & 1988 & 1989 & 1990 & 1991 & 1992 & 1993 & 1994 & 1995 \\
\hline Area Harvested (Thousand Hectares) ... & 1,302 & 1,202 & 1,267 & 1,241 & 1,380 & 1,243 & 1,455 & 1,355 \\
\hline $\begin{array}{l}\text { Methane Emissions-Low Estimate } \\
\text { (Thousand Metric Tons) } \ldots \ldots \ldots\end{array}$ & 131 & 121 & 127 & 124 & 138 & 126 & 147 & 137 \\
\hline $\begin{array}{l}\text { Methane Emissions-High Estimate } \\
\text { (Thousand Metric Tons) . . . . . }\end{array}$ & 693 & 642 & 674 & 656 & 732 & 668 & 779 & 727 \\
\hline
\end{tabular}

Source: Rice area harvested data from U.S. Department of Agriculture, National Agricultural Statistics Service, Crop Production annual reports. Emissions calculations based on Intergovernmental Panel on Climate Change, Greenhouse Gas Inventory Reference Manual, IPCC Guidelines for National Greenhouse Gas Inventories, Vol. 3 (Paris, France, 1995), pp. 4.46-4.55.

Table 25. U.S. Methane Emissions from Industrial Processes, 1988-1995

(Thousand Metric Tons of Methane)

\begin{tabular}{|c|c|c|c|c|c|c|c|c|}
\hline Source & 1988 & 1989 & 1990 & 1991 & 1992 & 1993 & 1994 & P1995 \\
\hline \multicolumn{9}{|l|}{ Chemical Production } \\
\hline Ethylene $\ldots \ldots \ldots \ldots$. & 17 & 16 & 17 & 18 & 18 & 19 & 22 & 21 \\
\hline Ethylene Dichloride ......... & 2 & 2 & 3 & 2 & 3 & 3 & 3 & 3 \\
\hline Styrene & 16 & 15 & 15 & 15 & 16 & 18 & 20 & 21 \\
\hline Methanol $\ldots \ldots \ldots \ldots \ldots$ & 7 & 7 & 8 & 8 & 7 & 10 & 10 & 10 \\
\hline Carbon Black $\ldots \ldots \ldots \ldots \ldots$ & 14 & 15 & 14 & 13 & 15 & 16 & 16 & 17 \\
\hline $\begin{array}{l}\text { Total } \ldots \ldots \ldots \ldots \ldots \ldots \\
\text { Iron and Steel Production }\end{array}$ & 57 & 55 & 56 & 57 & 60 & 66 & 72 & 72 \\
\hline Coke $^{\mathrm{a}} \ldots \ldots \ldots \ldots$ & 11 & 11 & 11 & 9 & 9 & 9 & 8 & 9 \\
\hline Sinter . . . . . . . . & 8 & 7 & 6 & 5 & 6 & 6 & 6 & 6 \\
\hline Pig Iron & 46 & 46 & 45 & 40 & 43 & 43 & 44 & 46 \\
\hline Total $\ldots \ldots \ldots \ldots \ldots \ldots$ & 64 & 64 & 62 & 54 & 57 & 58 & 59 & 61 \\
\hline Total Industrial Processes & 121 & 119 & 117 & 111 & 117 & 124 & 131 & 133 \\
\hline
\end{tabular}

${ }^{a}$ Based on total U.S. production of metallurgical coke, including non-iron and steel uses.

$P=$ preliminary data.

Note: Totals may not equal sum of components due to independent rounding.

Sources: American Iron and Steel institute, Annual Statistical Report (Washington, DC, various years); Chemical Manufacturers Association, U.S. Chemical Industry Statistical Handbook (Washington, DC, various years), p. 223; Intergovernmental Panel on Climate Change, Greenhouse Gas Inventory Reference Manual, IPCC Guidelines for National Greenhouse Gas Inventories, Vol. 3 (Paris, France, 1995), p. 2.6. 


\section{Nitrous Oxide Emissions}

\section{Overview}

\begin{tabular}{|c|c|c|}
\hline \multicolumn{3}{|c|}{$\begin{array}{l}\text { U.S. Anthropogenic Nitrous Oxide Emissions, } \\
1990-1995\end{array}$} \\
\hline & $\begin{array}{l}\text { Nitrous } \\
\text { Oxide }\end{array}$ & $\begin{array}{l}\text { Carbon } \\
\text { Equivalent }\end{array}$ \\
\hline $\begin{array}{l}\text { Estimated } 1995 \text { Emissions } \\
\text { (Million Metric Tons) }\end{array}$ & 0.47 & 39.1 \\
\hline $\begin{array}{l}\text { Change Compared to } 1994 \\
\text { (Million Metric Tons) }\end{array}$ & -0.09 & -0.7 \\
\hline $\begin{array}{l}\text { Change from } 1994 \\
\text { (Percent) }\end{array}$ & 1.8 & 1.8 \\
\hline $\begin{array}{l}\text { Change Compared to } 1990 \\
\text { (Million Metric Tons) }\end{array}$ & 0.13 & 1.1 \\
\hline $\begin{array}{l}\text { Change from } 1990 \\
\text { (Percent) }\end{array}$ & 3.0 & 3.0 \\
\hline
\end{tabular}

Compared to carbon dioxide or methane, nitrous oxide is released in small quantities from anthropogenic sources; however, nitrous oxide's 100-year global warming potential (GWP) of 310 makes it a significant contributor to atmospheric warming. ${ }^{40}$ As indicated in Table 26, the EIA estimates that anthropogenic nitrous oxide emissions in the United States totaled 462,000 metric tons in 1995. Sources for which data are available show slightly decreased emissions in 1995 associated with agricultural activities. ${ }^{41}$ Although there are many known natural and anthropogenic sources, emissions of nitrous oxide have been difficult to quantify on a global scale, primarily because it has been one of the least-studied greenhouse gases to date.

Figure 9 shows U.S. emissions of nitrous oxide by source over the period 1990-1995. The largest source of anthropogenic nitrous oxide emissions is energy use, which includes mobile source combustion from passenger cars, buses, motorcycles, and trucks, and stationary

\section{Principal Sources of U.S. Anthropogenic Nitrous Oxide Emissions, 1990-1995}

Thousand

Metric Tons Nitrous Oxide

Percent Change

\begin{tabular}{ccccc} 
& & & $1990-$ & $1994-$ \\
Source & 1990 & 1995 & 1995 & 1995 \\
\hdashline Energy Use & 188 & 184 & -2.2 & -0.6 \\
\hdashline Agriculture & 164 & 172 & 4.7 & -4.3 \\
\hdashline Industrial & 97 & 107 & 9.9 & 0.1 \\
\hdashline & & 16.1 \\
\hline
\end{tabular}

source combustion from residential, industrial, and electric utility energy use. Energy use was responsible for the release of a total of 184,000 metric tons of nitrous oxide in 1995, a decrease of 4,000 metric tons from the 1990 level.

\section{Figure 9. U.S. Emissions of Nitrous Oxide} by Source, 1990-1995

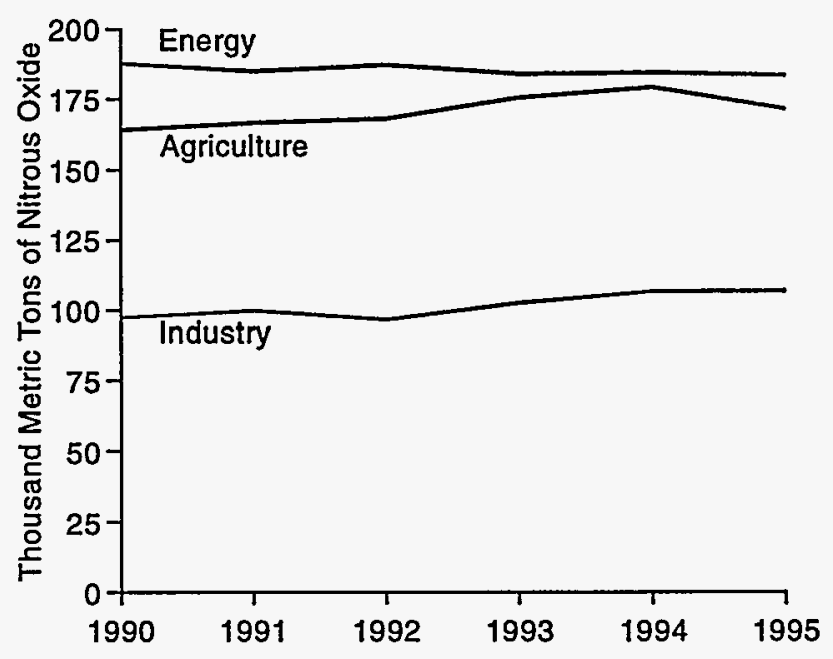

Source: Estimates presented in this chapter.

\footnotetext{
${ }^{40}$ Intergovernmental Panel on Climate Change, Climate Change 1995: The Science of Climate Change (Cambridge, UK: Cambridge University Press, 1996), p. 121.

${ }^{41}$ Discussion about data sources, methods of estimation, and other detailed background information is contained in the nitrous oxide section of Appendix A.
} 
The second-largest source of nitrous oxide emissions is agriculture, primarily fertilizer application and a small amount released from the burning of crop residues. Agricultural sources of nitrous oxide are estimated at 172,000 metric tons in 1995, an increase of 8,000 metric tons from 1990 and a decrease of 5,000 metric tons from 1994. However, there is substantial uncertainty and debate regarding the emissions implications of use of nitrogen-based fertilizers. Models used for estimation are based on limited sources of experimental data. For more information about methods and assumptions behind these estimates, see Appendix A.

Another important source of nitrous oxide emissions is industrial production of adipic acid and nitric acid, which together accounted for emissions of 107,000 metric tons of nitrous oxide in 1995, an increase of 10,000 metric tons from 1990 and virtually no change from 1994. Figure 10 shows changes in nitrous oxide emissions for the period 1990-1995. The largest increase in nitrous oxide emissions over the period is from industry. Emissions from energy use increased slightly from 1994 to 1995.

Figure 10. Difference in U.S. Nitrous Oxide Emissions by Source, 1990 vs. 1995

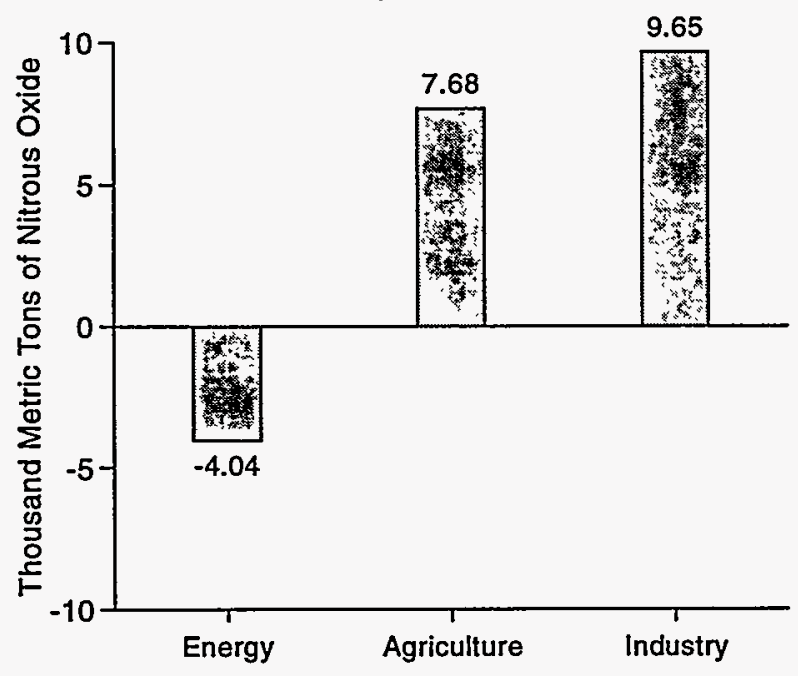

Source: Estimates presented in this chapter.

Overall, fertilizer use (which amplifies the natural flux of nitrous oxide from soil) and vehicular fuel combustion combine to account for approximately 70 percent of estimated emissions. Rapid growth in emissions from energy is largely responsible for the increase in anthropogenic nitrous oxide emissions observed since the early 1980s. In the 1990s, emissions from energy use have remained roughly stable, due primarily to changes in the composition of the motor vehicle fleet. Cars manufactured in the 1980s exhibited significantly higher nitrous oxide emissions rates than the majority of cars being retired from the fleet at that time. Beginning in 1990, however, the emissions rate for new cars declined below that of retiring vehicles. ${ }^{2}$ Emissions of nitrous oxide in the United States will probably continue to rise slowly as the proportion of the motor vehicle fleet using catalytic converters increases.

\section{Energy Use}

\begin{tabular}{|c|c|}
\hline \multicolumn{2}{|l|}{$\begin{array}{l}\text { U.S. Nitrous Oxide Emissions from. } \\
\text { Energy Use, 1990-1995 }\end{array}$} \\
\hline $\begin{array}{l}\text { Estimated } 1995 \text { Emissions } \\
\text { (Thousand Metric Tons Nitrous Oxide) }\end{array}$ & 184 \\
\hline $\begin{array}{l}\text { Change Compared to } 1994 \\
\text { (Thousand Metric Tons Nitrous Oxide) }\end{array}$ & -1 \\
\hline Change from 1994 (Percent) & -0.6 \\
\hline $\begin{array}{l}\text { Change Compared to } 1990 \\
\text { (Thousand Metric Tons Nitrous Oxide) }\end{array}$ & -4 \\
\hline Change from 1990 (Percent) & -2.2 \\
\hline
\end{tabular}

\section{Recent Trends}

Nitrous oxide emissions are a byproduct of fuel combustion in both mobile and stationary sources. In 1995, energy-related emissions are estimated to total 184,000 metric tons, equal to 40 percent of estimated total U.S. anthropogenic nitrous oxide emissions (Table 26). The estimates indicate that emissions from energy use were increasing sharply during the 1980 s but have been stable since 1990 (Figure 9).

\section{Mobile Combustion}

Nitrous oxide emissions from motor vehicles are influenced by a variety of factors, including fleet size, vehicle miles traveled, and emission control technologies. In addition, vehicles equipped with catalytic converters to reduce emissions of nitrogen oxides, carbon monoxide, and nonmethane volatile organic compounds emit up to 20 times more nitrous oxide than comparable vehicles without such emission control

\footnotetext{
${ }^{42}$ The number of vehicle miles traveled (VMT) has risen since the early 1980s. The decline in the emissions rates for the latest model cars has been outweighed by increases in VMT. Therefore, overall emissions from vehicles continue to increase.
} 
devices. ${ }^{43}$ Emissions from air, rail, and water transportation sources and from farm and construction equipment are included as "Other Mobile Sources" in Table 27.

Nitrous oxide emissions from mabile source combustion were estimated to be 145,000 metric tons in 1995 (Table 27). Approximately 88 percent of the emissions can be attributed to motor vehicles. Although passenger car fuel efficiency increased slightly in 1994, the fuel savings were roughly offset by increases in vehicle miles traveled, fleet size, fuel used per vehicle, and share of fleet with catalytic converters. Catalytic converters tend to increase emissions of nitrous oxide. This was particularly true of the early three-way catalyst systems used between 1983 and 1989; however, emissions from the advanced three-way catalyst systems introduced in 1990 are significantly lower. As a result, most of the 25-percent increase in emissions since 1987 occurred prior to 1991. Emissions have roughly stabilized in the 1990s, as vehicles with older higheremitting catalytic converters have been retired and replaced with vehicles with advanced three-way catalyst systems.

\section{Stationary Combustion}

During combustion, nitrous oxide is produced as a result of chemical interactions between nitric oxide and other combustion products. With most conventional combustion systems, high temperatures destroy almost all nitrous oxide, limiting the quantity that escapes; therefore, emissions from these systems are typically low.

In 1995, estimated nitrous oxide emissions from stationary combustion sources fell modestly, by 9,000 metric tons (Table 28). Combustion systems powered by coal clearly produce approximately 76 percent of total annual emissions. Electric utilities account for more than one-half of total emissions. Estimated nitrous oxide emissions from stationary combustion have increased by only 8 percent since 1987 .

\section{Agriculture}

\section{U.S. Nitrous Oxide Emissions from Agriculture, 1990-1995}

$$
\begin{aligned}
& \text { Estimated } 1995 \text { Emissions } \\
& \text { (Thousand Metric Tons Nitrous Oxide) }
\end{aligned}
$$

172

Change Compared to 1994

(Thousand Metric Tons Nitrous Oxide)

Change from 1994 (Percent) -4.3

Change Compared to 1990

(Thousand Metric Tons Nitrous Oxide)

8

Change from 1990 (Percent)

4.7

\section{Recent Trends}

On a global scale, agricultural practices contribute approximately 70 percent of anthropogenic nitrous oxide emissions. ${ }^{44,45}$ Their contribution was approximately 38 percent of U.S. emissions in 1994. Nitrogen flux to the atmosphere from the application of fertilizer is the principal source of agriculture-related emissions in the United States, and appears to be the single largest contributor of domestic anthropogenic nitrous oxide emissions, although estimates of agricultural nitrous oxide emissions are very uncertain (see Appen$\operatorname{dix}$ A). The disposal of crop residues by burning also produces nitrous oxide that is released into the atmosphere; however, the amount is relatively minor.

\section{Fertilizer Use}

Nitrous oxide uptake and emissions occur naturally as a result of nitrification and denitrification processes in soil. When nitrogen-based fertilizers are added to the soil, emissions generally increase, unless application precisely matches plant uptake and soil capture. ${ }^{46}$ The ELA estimates that 167,000 metric tons of nitrous oxide

${ }^{43}$ J.C. Kramlich and W.P. Linak, "Nitrous Oxide Behavior in the Atmosphere, and in Combustion and Industrial Systems," Progress in Energy and Combustion Science, Vol. 20 (1994), p. 196.

${ }^{44}$ Estimates for agriculture-related nitrous oxide emissions were the only estimates of anthropogenic nitrous oxide emissions available for 1995. The amount of nitrous oxide emitted from agricultural sources in 1994 was 179,000 metric tons, and this number, rather than the estimate for 1995, was included in the aggregate nitrous oxide emissions estimates presented in the beginning of this chapter.

${ }^{45}$ A.R. Mosier, "Nitrous Oxide Emissions from Agricultural Soils," in A.R. van Amstel (ed.), International IPCC Workshop Proceedings: Methane and Nitrous Oxide, Methods in National Emissions Inventories and Options for Control (Bilthoven, Netherlands: RIVM, 1993 ), p. 277.

${ }^{46}$ A.F. Bouwman, "Exchange of Greenhouse Gases Between Terrestrial Ecosystems and the Atmosphere," in A.F. Bouwman (ed.), Soils and the Greenhouse Effect (New York, NY: John Wiley and Sons, 1990). 
were released into the atmosphere as a result of fertilization practices in 1995 (Table 29).

\section{Crop Residue Burning}

As described in Chapter 3, incomplete combustion of agricultural wastes produces various gases, including methane and nitrous oxide. In 1995, burning of crop residues produced estimated emissions of nearly 5,000 metric tons of nitrous oxide (Table 26). Large fluctuations in annual crop production result in negligible variations in emissions, because only a small fraction of crops become waste, only 10 percent of crop waste is assumed to be burned, and less than 1 percent of the burned waste is released as nitrous oxide. The amount of nitrous oxide emitted as a result of this agricultural practice has been roughly stable since 1987.

\section{Industrial Processes}

\begin{tabular}{|c|c|}
\hline $\begin{array}{l}\text { U.S. Nitrous Oxide Emissions from } \\
\text { Industrial Processes, 1990-1995 }\end{array}$ & \\
\hline $\begin{array}{l}\text { Estimated } 1995 \text { Emissions } \\
\text { (Thousand Metric Tons Nitrous Oxide) }\end{array}$ & 107 \\
\hline $\begin{array}{l}\text { Change Compared to } 1994 \\
\text { (Thousand Metric Tons Nitrous Oxide) }\end{array}$ & 0 \\
\hline Change from 1994 (Percent) & 0.1 \\
\hline $\begin{array}{l}\text { Change Compared to } 1990 \\
\text { (Thousand Metric Tons Nitrous Oxide) }\end{array}$ & 10 \\
\hline Change from 1990 (Percent) & 9.9 \\
\hline
\end{tabular}

\section{Recent Trends}

Nitrous oxide is also emitted as a byproduct of certain chemical production processes. Table 30 provides estimates of emissions from the production of adipic acid and nitric acid, the two principal known sources. Emissions from the combination of these two processes have increased by 9.9 percent since 1990, although they remained stable from 1994 to 1995.

\section{Adipic Acid Production}

Adipic acid is a fine, white powder that is used primarily in the manufacture of nylon fibers and plastics, such as carpet yarn, clothing, and tire cord. Other uses of adipic acid include production of plasticizers for polyvinyl chloride and polyurethane resins, lubricants, insecticides, and dyes.

In the United States, three companies, which operate a total of four plants, manufacture adipic acid by oxidizing a ketone-alcohol mixture with nitric acid. Creation of nitrous oxide is an intrinsic byproduct of this chemical reaction. For every metric ton of adipic acid produced, 0.3 metric ton of nitrous oxide is created. ${ }^{47}$ Currently, two plants (accounting for approximately 77 percent of total production) control emissions by thermally decomposing the nitrous oxide, and 98 percent of the potential emissions from those plants are eliminated by this technique. ${ }^{48}$

In 1995, adipic acid production equaled 1994 production at 815,000 metric tons, resulting in stable levels of estimated nitrous oxide emissions from this source. However, this level of production represents a substantial increase from the 1993 level. Some of this growth may be attributed to increased demand for nylon fibers and polyvinyl chloride in 1994 and 1995.

\section{Nitric Acid Production}

Nitric acid is a primary ingredient in fertilizers. The process for manufacturing this acid involves oxidizing ammonia $\left(\mathrm{NH}_{3}\right)$ with a platinum catalyst. Nitrous oxide emissions are a direct result of the oxidation. Measurements at a DuPont plant indicate emissions factors of 2 to 9 grams of nitrous oxide per kilogram of nitric acid manufactured. ${ }^{49}$

The 8.6 million tons of nitric acid manufactured in 1995 resulted in estimated emissions of 47,000 metric tons of nitrous oxide. There is, however, a considerable degree of uncertainty associated with this estimate, because the emissions factor for the DuPont plant may not in fact be generalizable across the industry (see Appendix A).

\footnotetext{
${ }^{47}$ M.H. Thiemens and W.C. Trogler, "Nylon Production: An Unknown Source of Atmospheric Nitrous Oxide," Science, Vol. 251, No. 4996 (February 1991).

${ }^{48}$ Radian Corporation, Nitrous Oxide Emissions from Adipic Acid Manufacturing (Rochester, NY, January 1992$)$, p. 10.

${ }^{49}$ R.A. Reimer, R.A. Parrett, and C.S. Slaten, "Abatement of $\mathrm{N}_{2} \mathrm{O}$ Emission Produced in Adipic Acid," in Proceedings of the Fifth International Workshop on Nitrous Oxide Emissions (Tsukuba, Japan, July 1992).
} 
Table 26. Estimated U.S. Emissions of Nitrous Oxide, 1988-1995 (Thousand Metric Tons of Nitrous Oxide)

\begin{tabular}{|c|c|c|c|c|c|c|c|c|}
\hline Source & 1988 & 1989 & 1990 & 1991 & 1992 & 1993 & 1994 & 1995 \\
\hline \multicolumn{9}{|l|}{ Agriculture } \\
\hline Fertilizer . . . . . . . . . . . . . & 150 & 154 & 159 & 162 & 163 & 171 & 174 & 167 \\
\hline Crop Residue Burning . . . . . . . . . . & 4 & 5 & 5 & 5 & 5 & 4 & 6 & 5 \\
\hline Total $\ldots \ldots \ldots \ldots \ldots \ldots$ & 154 & 159 & . 164 & 167 & 168 & 176 & 179 & 172 \\
\hline \multicolumn{9}{|l|}{ Energy Use } \\
\hline Mobile Sources . . . . . . . . . . . . & 134 & 147 & 150 & 148 & 150 & 146 & 146 & 145 \\
\hline Stationary Combustion $\ldots \ldots \ldots \ldots$ & 38 & 38 & 37 & 37 & 37 & 38 & 39 & 39 \\
\hline Total $\ldots \ldots \ldots \ldots \ldots \ldots$ & 171 & 184 & 188 & 185 & 187 & 184 & 185 & 184 \\
\hline Industrial Sources . . . . . . . . . . . . & 95 & 100 & 97 & 100 & 96 & 103 & 107 & 107 \\
\hline Total $\ldots \ldots \ldots \ldots \ldots \ldots \ldots$ & 420 & 444 & 449 & 452 & 452 & 462 & 471 & 462 \\
\hline
\end{tabular}

Notes: Data in this table are revised from the data contained in the previous EIA report, Emissions of Greenhouse Gases in the United States 1987-1994, DOE/EIA-0573(87-94) (Washington, DC, October 1995). Totals may not equal sum of components due to independent rounding.

Sources: Estimates presented in this chapter. Crop residue burning-U.S. Department of Agriculture, National Agricultural Statistics Service, Crop Production annual reports. Emissions calculations based on Intergovernmental Panel on Climate Change, Greenhouse Gas Inventory Reference Manual, IPCC Guidelines for National Greenhouse Gas Inventories, Vol. 3 (Paris, France, 1995), pp. 4.69-4.73.

Table 27. U.S. Nitrous Oxide Emissions from Mobile Sources, 1988-1995 (Thousand Metric Tons of Nitrous Oxide)

\begin{tabular}{|c|c|c|c|c|c|c|c|c|}
\hline Item & 1988 & 1989 & 1990 & 1991 & 1992 & 1993 & 1994 & P1995 \\
\hline \multicolumn{9}{|l|}{ Motor Vehicles } \\
\hline Passenger Cars & 79 & 87 & 90 & 88 & 90 & 83 & 82 & 84 \\
\hline Buses $\ldots \ldots \ldots \ldots \ldots \ldots$ & * & * & * & * & * & * & * & * \\
\hline Motorcycles . . . . . . . . . . . & * & * & * & $*$ & * & * & * & * \\
\hline Light-Duty Trucks .......... & 31 & 35 & 36 & 35 & 35 & 37 & 38 & 35 \\
\hline Other Trucks ....... & 7 & 7 & 7 & 8 & 8 & 8 & 9 & 9 \\
\hline Total ................. & 117 & 130 & 133 & 131 & 133 & 129 & 129 & 128 \\
\hline Other Mobile Sources . . . . . . . & 17 & 17 & 17 & 17 & 17 & 17 & 17 & 17 \\
\hline Total Mobile Sources ... & 134 & 147 & 150 & 148 & 150 & 146 & 146 & 145 \\
\hline
\end{tabular}

$P=$ preliminary data.

*Less than 500 metric tons of nitrous oxide.

Notes: Data in this table are revised from the data contained in the previous EIA report, Emissions of Greenhouse Gases in the United States 1987-1994, DOE/EIA-0573(87-94) (Washington, DC, October 1995). Totals may not equal sum of components due to independent rounding.

Sources: Calculations based on vehicle miles traveled from U.S. Department of Transportation, Federal Highway Statistics, various years, Table VM-1. Vehicle emissions coefficients from Intergovernmental Panel on Climate Change, Greenhouse Gas Inventory Reference Manual, IPCC Guidelines for National Greenhouse Gas Inventories, Vol. 3 (Paris, France, 1995), pp. 1.64-1.68. 
Table 28. U.S. Nitrous Oxide Emissions from Stationary Combustion Sources, 1988-1995 (Thousand Metric Tons of Nitrous Oxide)

\begin{tabular}{|c|c|c|c|c|c|c|c|c|}
\hline Source & 1988 & 1989 & 1990 & 1991 & 1992 & 1993 & 1994 & 1995 \\
\hline Commercial $\ldots \ldots \ldots \ldots \ldots$ & 1 & 1 & 1 & 1 & 1 & 1 & 1 & 1 \\
\hline Coal $\ldots \ldots \ldots \ldots \ldots \ldots$ & * & * & $\star$ & - & * & - & * & * \\
\hline$\ldots \ldots \ldots \ldots \ldots \ldots$ & 1 & 1 & 1 & 1 & 1 & 0 & 0 & 0. \\
\hline Natural Gas $\ldots \ldots \ldots \ldots \ldots$ & * & * & * & * & $\star$ & * & - & - \\
\hline Residential $\ldots \ldots \ldots \ldots \ldots$. & 2 & 2 & 1 & 1 & 1 & 1 & 1 & 1 \\
\hline Coal $\ldots \ldots \ldots \ldots \ldots \ldots$ & 0 & 0 & 0 & 0 & 0 & 0 & 0 & 0 \\
\hline Fuel Oil $\ldots \ldots \ldots \ldots \ldots \ldots$ & 1 & 1 & 1 & 1 & 1 & 1 & 1 & 1 \\
\hline Natural Gas $\ldots \ldots \ldots \ldots \ldots$ & 1 & 1 & * & * & 1 & 1 & 1 & 1 \\
\hline Industrial $\ldots \ldots \ldots \ldots \ldots \ldots$ & 10 & 10 & 10 & 10 & 10 & 10 & 10 & 10 \\
\hline Coal $\ldots \ldots \ldots \ldots \ldots \ldots$ & 4 & 4 & 4 & 4 & 4 & 4 & 4 & 4 \\
\hline Fuel Oil $\ldots \ldots \ldots \ldots \ldots$ & 5 & 5 & 5 & 5 & 5 & 5 & 6 & 6 \\
\hline Natural Gas ............. & 1 & 1 & 1 & 1 & 1 & 1 & 1 & 1. \\
\hline Electric Utility . . . . . . . . . & 25 & 25 & 25 & 25 & 25 & 26 & 26 & 26 \\
\hline Coal $\ldots \ldots \ldots \ldots \ldots \ldots$ & 23 & 24 & 24 & 24 & 24 & 25 & 25 & 25 \\
\hline Fuel Oil $\ldots \ldots \ldots \ldots \ldots \ldots$ & 1 & 1 & 1 & 1 & 1 & 1 & 1 & - \\
\hline Natural Gas..$\ldots \ldots \ldots$. & * & * & * & • & $\star$ & * & - & • \\
\hline \multicolumn{9}{|l|}{ Fuel Totals } \\
\hline Coal . . . . . & 28 & 28 & 28 & 28 & 28 & 29 & 29 & 29 \\
\hline$\ldots \ldots \ldots \ldots \ldots$ & 8 & 8 & 7 & 7 & 7 & 7 & 8 & 7 \\
\hline Natural Gas ............... & 2 & 2 & 2 & 2 & 2 & 2 & 2 & 2 \\
\hline Total (All Fuels) $\ldots$. $\ldots \ldots \ldots$ & 38 & 38 & 37 & $37^{\prime}$ & 37 & 38 & 39 & 39 \\
\hline
\end{tabular}

*Less than 500 metric tons of nitrous oxide.

Notes: Data in this table are revised from the data contained in the previous EIA report, Emissions of Greenhouse Gases in the United States 1987-1994, DOE/EIA-0573(87-94) (Washington, DC, October 1995).

Totals may not equal sum of components due to independent rounding.

Sources: Emissions coefficients from Intergovernmental Panel on Climate Change, Greenhouse Gas Inventory Reference Manual, IPCC Guidelines for National Greenhouse Gas Inventories, Vol. 3 (Paris, France, 1995), p. 1.50. Energy consumption data from Energy Information Administration, State Energy Data Report 1994, DOE/EIA-0214(94) (Washington, DC, July 1996); and Monthly Energy Review, DOE/EIA-0035(96/07) (Washington, DC, July 1996).

Table 29. U.S. Nitrous Oxide Emissions from Nitrogen Fertilizer Use, 1988-1995

(Thousand Metric Tons of Nitrous Oxide)

\begin{tabular}{c|r|r|r|r|r|r|r|r}
\hline Source & 1988 & 1989 & 1990 & 1991 & 1992 & 1993 & 1994 & 1995 \\
\hline Low Estimate $\ldots \ldots \ldots \ldots \ldots \ldots$ & 15 & 15 & 16 & 16 & 16 & 17 & 17 & 17 \\
Median Estimate . . . . . . . & 150 & 154 & 159 & 162 & 163 & 171 & 174 & 167 \\
High Estimate . . . . . . . . & 1,504 & 1,545 & 1,594 & 1,620 & 1,628 & 1,713 & 1,737 & 1,671 \\
\hline
\end{tabular}

Note: Data in this table are revised from the data contained in the previous EIA report, Emissions of Greenhouse Gases in the United States 1987-1994, DOE/EIA-0573(87-94) (Washington, DC, October 1995).

Sources: Emissions coefficients from Intergovernmental Panel on Climate Change, Methane and Nitrous Oxide Methods in National Emissions Inventories and Options for Control, Proceedings, Research for Man and Environment (Netherlands, February 1993), p. 274. Total nitrogen content of U.S. fertilizer consumption: 1988-1994, Tennessee Valley Authority; 1995, Association of American Plant Food Control Officials, Commercial Fertilizers 1995 (Lexington, KY, 1996). 
Table 30. U.S. Nitrous Oxide Emissions from Industrial Processes, 1988-1995 (Thousand Metric Tons of Nitrous Oxide)

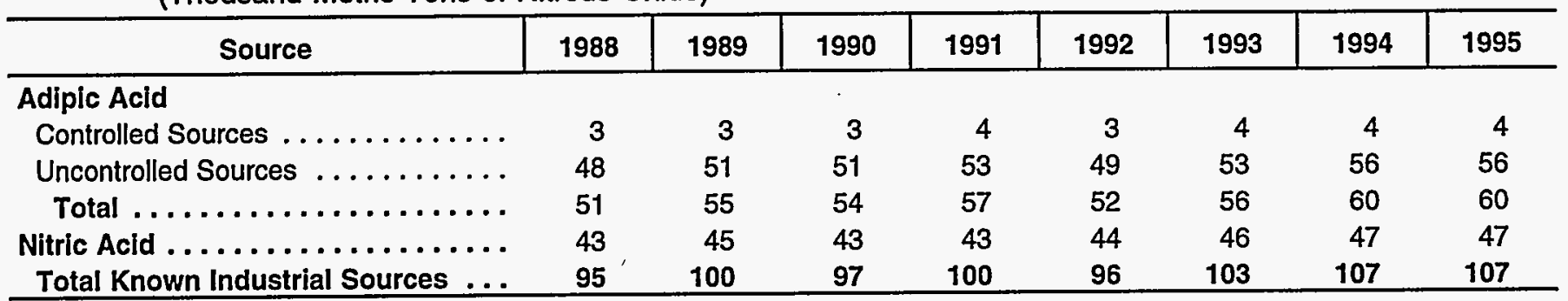

Notes: Data in this table are revised from the data contained in the previous EIA report, Emissions of Greenhouse Gases in the United States 1987-1994, DOE/EIA-0573(87-94) (Washington, DC, October 1995). Totals may not equal sum of components due to independent rounding.

Sources: Data sources and methods documented in Appendix A. 



\section{Halocarbons and Other Gases}

\section{Overview}

Total U.S. Emissions of Hydrofluorocarbons,
Perfluorocarbons, and Sulfur Hexafluoride,
$1990-1994$
Estimated 1994 Emissions
(Million Metric Tons Carbon Equivalent)
Change Compared to 1993
(Million Metric Tons Carbon Equivalent)
Change from 1993 (Percent)

Emissions of halocarbons and other gases with unambiguous global warming effects (hydrofluorocarbons [HFCs], perfluorocarbons [PFCs], and sulfur hexafluoride) have risen rapidly, though from very low levels, in recent years. HFCs were first widely used commercially in the 1990s, when they were introduced as replacements for chlorofluorocarbons (CFCs), whose use is being phased out, pursuant to the Montreal Protocol, because they damage the Earth's ozone layer.

CFCs, hydrochlorofluorocarbons (HCFCs), and several other chlorine-containing gases, have ambiguous effects on global climate change, since their capacity to absorb reflected infrared radiation is offset to some degree by their tendency to react with ozone, which is itself a greenhouse gas. Hence, ozone-depleting substances are not directly included in the total emissions of greenhouse gases described in this report. Emissions of ozone-depleting substances are, however, described in this chapter, since their emissions are believed to have some effect on global climate.
Table 31 summarizes the 1994 U.S. sales, emissions, and global warming potentials of the halocarbons and other gases described in this chapter. U.S. production and sales of many of these chemicals are surveyed by the International Trade Commission. ${ }^{50}$ Establishments emitting more than 25,000 pounds annually of many ozone-depleting substances are required to report their emissions, disposals, and recycling of these substances to the EPA's Toxics Release Inventory (TRI). ${ }^{51}$ These data exclude many greenhouse gases and most smallscale emissions, but they offer insight into manufacturing emissions. Finally, the Alternative Fluorocarbons Environmental Acceptability Study (AFEAS) reports on production, sales, and emissions of a range of manufactured greenhouse gases and ozone-depleting substances for most of the world, but does not disaggregate emissions by country. ${ }^{52}$

Table 32 summarizes emissions by gas from 1988 to 1995. Emissions of CFCs have declined rapidly in the 1990s, while emissions of HCFCs have expanded. Emissions of HFCs, sparked by the rapid growth in use of HFC-134a in motor vehicles, have grown rapidly in the past 2 years and will continue to do so through the 1990s. Estimated emissions of PFCs have declined in recent years along with declining aluminum production in the United States. Emissions of other gases, which are either ozone-depleting substances, carcinogens, or both, have declined considerably in recent years.

\section{Chlorofluorocarbons (CFCs)}

CFCs are derivatives of hydrocarbons, which are composed of carbon and hydrogen atoms. In CFCs, the hydrogen atoms are replaced with chlorine and fluorine atoms, yielding an array of nontoxic, nonflammable gases useful in a wide variety of applications. CFCs have no natural source, and their high molecular stability allows them to migrate to the stratosphere, where they destroy ozone. Though molecule for molecule they absorb thousands of times more infrared radiation than

\footnotetext{
${ }^{50}$ U.S. International Trade Commission, Synthetic Organic Chemicals: United States Production and Sales, 1994 (Washington, DC, March 1995).

${ }^{51}$ U.S. Environmental Protection Agency, 1994 Toxics Release Inventory: Public Data Release (Washington, DC, July 1996$)$, p. 14.

${ }^{52}$ Alternative Fluorocarbons Environmental Acceptability Study, Production, Sales and Atmospheric Release of Fluorocarbons Through 1994 (Washington, DC, October 1995).
} 
carbon dioxide, their net warming affect is reduced because of their effect on ozone. Ozone $\left(\mathrm{O}_{3}\right)$, beneficial in the stratosphere for its ability to absorb harmful ultraviolet radiation, is also a potent greenhouse gas. Thus, while the direct effect of CFCs is a warming potential far greater than that of carbon dioxide, their indirect effect on ozone reduces their net radiative forcing effects by half. ${ }^{53}$

The Copenhagen Amendments of the Montreal Protocol suggest phasing out CFCs by 1996 . The United States is implementing these provisions through the Clean Air Act Amendments of 1990 and subsequent EPA regulations, which include allowable production quotas and taxes on inventories and stocks. All production ceased in January 1996, with the exception of small amounts used in metered dose inhalers for asthma patients, for which no substitutes are available.

\section{Trichlorofluoromethane (CFC-11)}

CFC-11 is principally used as a blowing agent for foams and packaging materials and as a refrigerant in large commercial chillers. Sales have been declining steadily since 1988 , with production following roughly the same trend, except for a spike in $1992 .{ }^{54}$ In 1994 , production and sales declined by nearly 80 percent, to only 7,000 metric tons. ${ }^{55}$ This implies that CFC-11 has been phased out of the blowing agent market completely, and residual CFC-11 is probably used only for chillers. This will be a shrinking source of emissions, as no new CFC-11 chillers are being built, and existing chillers are likely to be retrofitted to use other coolants.

\section{Dichlorofluoromethane (CFC-12)}

CFC-12 is often known by its trade name, "freon-12." Exceedingly versatile, its end uses include air conditioning (both automotive and commercial); refrigeration (refrigerators and freezers of varying scales); and as a blowing agent for foams, insulations, and packaging. The signing of the Montreal Protocol in 1987 caused trends in its production, sales, and emissions to fluctuate. Before 1987, the production, sale, and end use of CFC-12 were all nearly equivalent. In 1988 and 1989, production and sales were well above the estimated amount of CFC-12 being incorporated in end uses, suggesting that end users were stockpiling the compound in response to the expected cessation of U.S. production. Production and sales dropped dramatically in 1990 and 1991, falling below estimates of end-use applications and emissions. In recent years, the four figures have once again become consistent, with end use gradually declining as CFCs are phased out (Figure 11). ${ }^{56}$

\section{Figure 11. Production, Sales, End Use, and Estimated Emissions of CFC-12, 1980-1995}

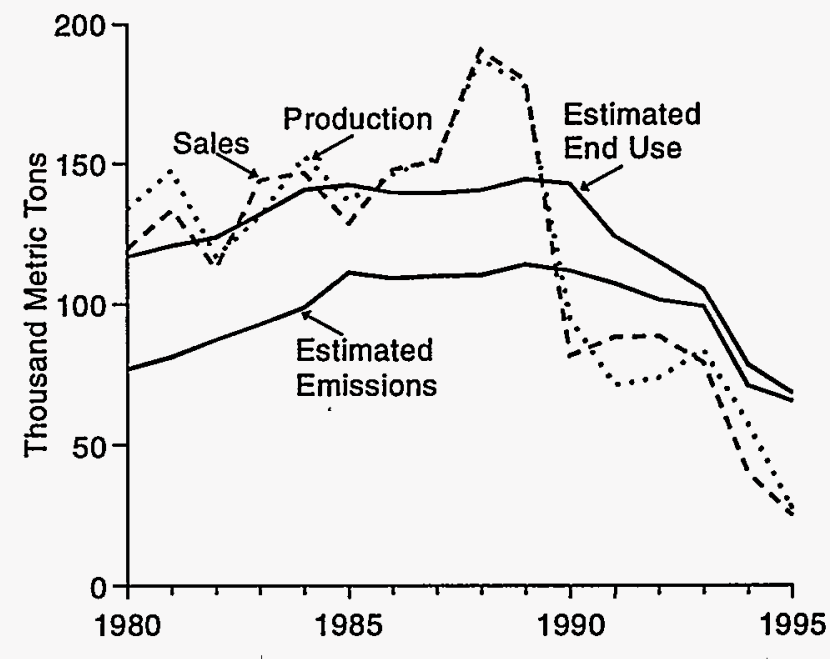

Sources: Production and Sales-International Trade Commission, Synthetic Organic Chemicals (various years). Estimated End Use and Emissions-ElA estimates based on sales of CFC-using equipment.

AFEAS data suggest that use of CFC-12 as a blowing agent decreased by nearly 90 percent between 1988 and 1994..$^{57}$ The use of CFC-12 in refrigeration, however, declined more slowly until 1994. During 1994, automobile, refrigerator, and commercial chiller manufacturers essentially ceased using CFC-12 in their products completely.

In the past year, with production of $\mathrm{CFC}-12$ ending and prices rising sharply, their has been an epidemic of CFC smuggling, particularly from Eastern Europe. A

\footnotetext{
${ }^{53}$ See Chapter 1 of this report, especially Table 4 on page 7.

${ }^{54}$ U.S. International Trade Commission, Synthetic Organic Chemicals: United States Production and Sales, 1993 (Washington, DC, November 1994), p. 3-21.

${ }^{55}$ U.S. International Trade Commission, Synthetic Organic Chemicals: United States Production and Sales, 1994 (Washington, DC, March 1995), p. 3-21.

${ }^{56}$ U.S. International Trade Commission, Synthetic Organic Chemicals: United States Production and Sales, 1993 (Washington, DC, November 1994), p. 3-21.

${ }^{57}$ Alternative Fluorocarbons Environmental Acceptability Study, Production, Sales and Atmospheric Release of Fluorocarbons Through 1994 (Washington, DC, October 1995), p. 1-10.
} 
number of individuals have been arrested for smuggling CFC-12 into the United States, particularly in Florida. ${ }^{58}$ U.S. Customs believes that CFC-12 may now be the most commonly smuggled commodity after illicit drugs.

Current emissions of $\mathrm{CFC}-12$ from the now dwindling stock of existing equipment are probably on the order of 60,000 to 70,000 metric tons. However, in the next few years, emissions should decline rapidly. At present, emissions are being sustained by the large stock of CFC-using equipment, such as refrigerators and automobile air conditioners. However, the high prices and limited availability of CFC-12 will increasingly encourage people to discard or retrofit rather than repair CFC-using equipment when it fails.

\section{Freon 113 (CFC-113)}

CFC-113, also known as "freon 113 ," is principally used as a solvent. In particular, it is a useful cleaner for electronic circuit boards, because it volatilizes easily and will not damage the circuitry. Such an end use, and others consistent with it as detailed in AFEAS, imply that emissions of CFC-113 are roughly equivalent to production.

Estimated emissions of CFC-113 have been declining rapidly since 1988. In 1994, emissions of CFC-113 reported in the TRI were about 2,300 metric tonsdown substantially from the 11,000 metric tons in $1992 .{ }^{59}$ Recycling and treatment of CFC-113 have also declined in recent years, indicating that CFC-113 is being phased out in favor of alternatives.

\section{Dichlorotetrafluoroethane (CFC-114)}

CFC-114 is principally used as a solvent. According to AFEAS, roughly two-thirds of all CFC-114 sales go toward short-lifetime end uses, such as cleaning and drying agents, with the rest being used in closed-cell foams and refrigeration applications, where the compound may remain trapped for up to 12 years. ${ }^{60}$ In addition, the U.S. Department of Energy uses CFC-114 in the enrichment of uranium. Emissions reported in the TRI, which are a reasonable proxy for industrial emissions, were only 600 metric tons. ${ }^{61}$

\section{Monochloropentafluoroethane (CFC-115)}

CFC-115 is used primarily as a blending agent for some specialty refrigerants. Northern hemisphere sales in 1994 were only 7,000 metric tons. ${ }^{62}$ U.S. emissions in the early 1990s were less than 300 metric tons annually, declining to 150 metric tons in $1994 .{ }^{63}$

\section{Hydrochlorofluorocarbons (HCFCs)}

HCFCs are essentially CFCs that include one or more hydrogen atoms. The presence of hydrogen makes the resulting compounds less stable, and as a result they are more susceptible to photodecomposition, have much shorter atmospheric lifetimes than CFCs, and consequently are less likely to migrate to the stratosphere where they would destroy ozone. As a result, they are popular interim substitutes for CFCs. The Copenhagen Amendments placed HCFCs under control, with HCFC-22 slated for elimination by 2020 and all others by 2030 . HCFCs still have high GWPs, and these are compounded by the fact that they have weaker indirect cooling effects than do CFCs.

\section{Chlorodifluoromethane (HCFC-22)}

HCFC-22 is the most commonly used refrigerant for home air conditioning systems. It is the most widely available and least expensive potential substitute for CFCs in a variety of applications. However, the available evidence suggests that $\mathrm{HCFC}-22$ gained most of its market share at the expense of CFCs in the late 1980s. Total U.S. sales of HCFC-22 declined from 108,000 metric tons in 1991 to 97,000 metric tons in 1994. Production has historically exceeded sales by a substantial margin.

Estimated emissions of HCFC-22 have been rising slowly. AFEAS data suggest that the increased usage of HCFC-22 for long- and medium-lifetime uses has created a "banked" inventory of the compound that is now being emitted.

58"CFC Smuggling a Big Business in Miami," Christian Science Monitor (August 23, 1995), p. 3.

${ }^{59}$ U.S. Environmental Protection Agency, 1994 Toxics Release Inventory: Public Data Release (Washington, DC, July 1996), p. 64.

${ }^{60}$ Alternative Fluorocarbons Environmental Acceptability Study, Production, Sales and Atmospheric Release of Fluorocarbons Through 1993 (Washington, DC, March 1995), p. 2-10.

${ }^{61}$ U.S. Environmental Protection Agency, 1994 Toxics Release Inventory: Public Data Release (Washington, DC, July 1996), p. 64.

${ }^{62}$ Alternative Fluorocarbons Environmental Acceptability Study, Production, Sales and Atmospheric Release of Fluorocarbons Through 1994 (Washington, DC, October 1995), p. 7.

${ }^{63}$ U.S. Environmental Protection Agency, 1994 Toxics Release Inventory: Public Data Release (Washington, DC, July 1996), p. 68. 


\section{1,1-Dichloro-1-fluoroethane (HCFC-141b)}

HCFC-141b is a relatively new commercial product, used primarily as a solvent and as a blowing agent for closed-cell foams, with a net GWP of 270 . Northern hemisphere sales rose from less than 1,000 metric tons in 1990 to 78,000 metric tons in $1994 .{ }^{64}$ The EPA estimates 1994 U.S. emissions of HCFC-141b at 16,000 metric tons. ${ }^{65}$ Based on the extensive use of HCFC-141b in solvents and closed-cell foams, it is likely that emissions of this chemical expanded substantially in 1995.

\section{Chlorodifluoroethane (HCFC-142b)}

HCFC-142b is a CFC replacement with a net GWP of 1,650 . U.S. production and sales data are not available. AFEAS collects information on worldwide production, which taken in conjunction with information on northern hemisphere sales can be used to estimate a ceiling on U.S. sales or emissions. In 1994, worldwide production continued to grow, reaching nearly 40,000 metric tons. ${ }^{66}$ Of that amount, approximately 3,000 metric tons were sold for short-lifetime end uses, including sterilants, inhalers, and open-cell foams. ${ }^{67}$ The EPA estimated 1994 emissions of HCFC-142b at 10,000 metric tons. ${ }^{68}$ This figure implies that most of the worldwide production of $\mathrm{HCFC}-142 \mathrm{~b}$ may be taking place in the United States. Based on the growing use of HCFC-142b for closed-cell foam applications, it is likely that emissions increased substantially in 1995.

\section{Other HCFCs}

A number of HCFCs may gain importance as CFCs are phased out in the near future. HCFC-123 is a potential replacement for $\mathrm{CFC}-11$ in refrigeration applications, and HCFC-124 is a potential replacement for CFC-12 in sterilizers. The TRI reported HCFC-123 and HCFC-124 emissions of 2,400 and 380 metric tons, respectively, in $1994 .{ }^{69}$ The EPA estimates 1994 total HCFC-124 emissions at 2,000 metric tons. The EPA believes that 1990 emissions of these chemicals were negligible.

\section{Hydrofluorocarbons (HFCs)}

\begin{tabular}{|c|c|}
\hline $\begin{array}{l}\text { Estimated } 1994 \text { Emissions } \\
\text { (Million Metric Tons Carbon Equivalent) }\end{array}$ & 18.6 \\
\hline $\begin{array}{l}\text { Change Compared to } 1993 \\
\text { (Million Metric Tons Carbon Equivalent) }\end{array}$ & 3.8 \\
\hline Change from 1993 (Percent) & 25.7 \\
\hline $\begin{array}{l}\text { Change Compared to } 1990 \\
\text { (Million Metric Tons Carbon Equivalent) }\end{array}$ & 5.3 \\
\hline Change from 1990 (Percent) & 39.8 \\
\hline
\end{tabular}

HFCs are hydrochlorofluorocarbons without the chlorine. Because they contain only carbon, hydrogen, and fluorine, they do not destroy ozone. Consequently, they are a desirable CFC replacement. Ironically, the characteristic that makes them a desirable replacement from an ozone perspective also makes them potent greenhouse gases with no offsetting indirect effects.

The market for HFCs.is expanding as CFCs are being phased out. It is difficult to keep pace with the variety of HFCs that are being developed and the quantities being produced. Consequently, accurate data are difficult to obtain.

\section{HFC-23}

HFC-23 is created as a byproduct in the production of HCFC-22. Small amounts are also used in semiconductor manufacture. Emissions are estimated at between 2 and 4 percent of total HCFC-22 production, implying a total of 3,000 to 5,000 metric tons per year. ${ }^{70}$ Although this total seems small, the GWP of HFC-23 is very large at 11,700 -giving it a substantial

\footnotetext{
${ }^{64}$ Alternative Fluorocarbons Environmental Acceptability Study, Production, Sales and Atmospheric Release of Fluorocarbons Through 1994 (Washington, DC, October 1995), p. 8.

${ }^{65}$ U.S. Environmental Protection Agency, Inventory of U.S. Greenhouse Gas Emissions and Sinks, 1990-1994 (Washington, DC, October 1995), p. 50.

${ }^{66}$ Alternative Fluorocarbons Environmental Acceptability Study, Production, Sales and Atmospheric Release of Fluorocarbons Through 1994 (Washington, DC, October 1995), p. 6.

${ }^{67}$ Alternative Fluorocarbons Environmental Acceptability Study, Production, Sales and Atmospheric Release of Fluorocarbons Through 1993 (Washington, DC, March 1995), p. 4-8.

${ }^{68}$ U.S. Environmental Protection Agency, Inventory of U.S. Greenhouse Gas Emissions and Sinks, 1990-1994 (Washington, DC, October 1995), p. 50.

${ }^{69}$ U.S. Environmental Protection Agency, 1994 Toxics Release Inventory: Public Data Release (Washington, DC, July 1996), p. 68.

${ }^{70}$ U.S. Department of Energy, The Climate Change Action Plan: Technical Supplement, DOE/PO-0011 (Washington, DC, March 1994), p. 67.
} 
direct effect without any known offsetting indirect effects. The Climate Change Action Plan includes a voluntary program with $\mathrm{HCFC}-22$ producers to reduce emissions and explore potential markets for HFC-23 as a halon replacement and refrigerant.

\section{1,2,2,2-Tetrafluoroethane (HFC-134a)}

HFC-134a, with a GWP of 1,300 , is gaining importance as a replacement for $C F C$, especially in automotive air conditioners. Emissions for 1990 were estimated at only 500 metric tons, but they will likely grow significantly as HFC-134a gains market share. In 1993, Ford sold nearly 40,000 vehicles each of which used approximately 2 pounds of HFC-134a in its air conditioner. ${ }^{71}$ Previous models used about 2.5 pounds of CFC- 12 . Essentially all 1994 and subsequent model year automobiles use HFC-134a as the refrigerant in their air conditioners. Many manufacturers now offer HFC-134a conversion packages for older cars through their dealerships.

Automobile air conditioners are subject to significant leakage, with sufficient refrigerant leaking out ( 30 percent or more of the charge) over a 5-year period to require servicing. This would suggest that 1993 emissions of HFC-134a from automotive sources totaled only 15 metric tons. In 1994, however, with millions of new vehicles using HFC-134a, automotive emissions may have risen by two orders of magnitude. With increased production and usage of HFC-134a in replacement applications, emissions are expected to increase dramatically in future years.

HFC-134a is also used as refrigerant in most new refrigerators built in the United States, in commercial chillers, and to a limited extent as a solvent and blowing agent.

The EPA estimated 1994 emissions of HFC-134a at about 10,000 metric tons, and 1995 emissions should be at least 50 percent higher than 1994 emissions.

\section{1,1-Difluoroethane (HFC-152a)}

As a non-ozone-depleting substance with a GWP of only 140, HFC-152a is an attractive potential replacement for CFCs. It can be used as a blowing agent, an ingredient in refrigerant blends (e.g., in R-500), and in fluoropolymer manufacturing applications. It is also compatible with the components used in aerosol products. Unlike CFCs, however, HFC-152a is flammable.
Only one company (DuPont) produces HFC-152a, using the trade name Dymel-152a, and in 1995 the company reported having doubled its production capacity to 35 million pounds since $1992 .^{72}$ Consequently, DuPont probably was producing HFC-152a near full capacity in 1994. This corresponds to production of about 8,000 metric tons, which places a ceiling on emissions. The EPA estimated 1990 emissions of HFC-152a at only 300 metric tons, rising to 1,500 metric tons by 1994 . The doubling of production capacity implies that 1995 emissions were considerably higher than 1994 emissions. As HFC-152a gains market share forfeited by CFCs and replacements with higher GWPs, emissions are likely to increase significantly in future years.

\section{Other HFCs}

Several other "new" hydrofluorocarbons with considerable radiative forcing potential are beginning to appear on the market. These include HFC-32 $\left(\mathrm{CH}_{2} \mathrm{~F}_{2}\right)$ and HFC-125 $\left(\mathrm{C}_{2} \mathrm{HF}_{5}\right)$, with 100-year global warming potentials of 650 and 2,800, respectively, both of which are used as components in refrigerant blends. The EPA estimated 1994 emissions of HFC-125 at about 1,000 metric tons. ${ }^{73}$ Other prospective HFCs include HFC-143a $\left(\mathrm{C}_{2} \mathrm{H}_{3} \mathrm{~F}_{3}\right)$, HFC-227ea $\left(\mathrm{C}_{3} \mathrm{HF}_{7}\right)$, and HFC-236fa $\left(\mathrm{C}_{3} \mathrm{H}_{2} \mathrm{~F}_{6}\right)$, with 100-year global warming potentials of $3,800,2,900$, and 6,300, respectively. The EPA has estimated 1994 emissions of HFC-227ea at about 900 metric tons.

\section{Bromofluorocarbons (Halons)}

Bromofluorocarbons are similar to CFCs except that they contain at least one bromine atom. They are inert, nontoxic, and evaporate without leaving any residue, making them popular for use as fire suppressants for high-value equipment such as computer centers and aircraft. The trade name "halon" is applied to several of these chemicals, which are used as fire suppressants. Halons are particularly destructive to stratospheric ozone, and consequently production will cease in 1996 as per agreements in the Montreal Protocol. The U.S. military, which uses a significant volume of halons to protect sensitive equipment, is involved in a program to reduce emissions through recycling, using substitutes, and preventing leakage of halons in existing systems. Emissions of halons are low, although the exact figure is uncertain. The EPA estimated 1994 emissions at 2,000 metric tons for halon-1301 and 1,000 metric tons for halon- 1211 .

\footnotetext{
${ }^{71}$ Information obtained during spoken communication with Ford representatives.

72"DuPont Set to Expand Markets for Ozone-Safe HFC-152a Product," Ozone Depletion Online Today (Alexandria, VA, June 9, 1995).

${ }^{73}$ U.S, Environmental Protection Agency, Inventory of U.S. Greenhouse Gas Emissions and Sinks, 1990-1994, EPA-230-R-96-006 (Washington, DC, November 1995), p. 47.
} 


\section{Perfluorocarbons (PFCs)}

\begin{tabular}{|c|c|}
\hline \multicolumn{2}{|l|}{$\begin{array}{l}\text { U.S. Emissions of Perfluorocarbons, } \\
1990-1994\end{array}$} \\
\hline $\begin{array}{l}\text { Estimated } 1994 \text { Emissions } \\
\text { (Million Metric Tons Carbon Equivalent) }\end{array}$ & 4.2 \\
\hline $\begin{array}{l}\text { Change Compared to } 1993 \\
\text { (Million Metric Tons Carbon Equivalent) }\end{array}$ & -0.5 \\
\hline Change from 1993 (Percent) & -10.7 \\
\hline $\begin{array}{l}\text { Change Compared to } 1990 \\
\text { (Million Metric Tons Carbon Equivalent) }\end{array}$ & -1.0 \\
\hline Change from 1990 (Percent) & -18.5 \\
\hline
\end{tabular}

Perfluorocarbons are hydrocarbons in which the hydrogen has been replaced by fluorine. Since they contain no chlorine, they are not harmful to ozone and therefore do not possess the indirect cooling effects of CFCs. As a result, they are unambiguously greenhouse gases. The principal quantifiable source of PFCs is as a byproduct of aluminum smelting. The EPA estimates that 0.6 kilogram of perfluoromethane $\left(\mathrm{CF}_{4}\right.$, also known as carbon tetrafluoride) and 0.06 kilogram of perfluoroethane $\left(\mathrm{C}_{2} \mathrm{~F}_{6}\right)$ are emitted as a result of each metric ton of aluminum smelted. ${ }^{74}$ These coefficients, in conjunction with aluminum production figures, suggest U.S. emissions of 2,200 metric tons of perfluoromethane and 220 metric tons of perfluoroethane in 1993. Perfluoromethane is also emitted during the process of uranium enrichment, at a rate that probably is less than 20 metric tons per year. ${ }^{75}$ Another minor emissions source is a National Aeronautics and Space Administration hypersonic wind tunnel.

The principal source of PFC emissions, after aluminum smelting, is probably semiconductor manufacturing. Perfluoroethane is used as a purging agent in semiconductor manufacturing. The process produces fugitive emissions of perfluoroethane, perfluoromethane, and sulfur hexafluoride. The sole U.S. producer, DuPont, reports that it plans to double its perfluoroethane production capacity in 1995, while encouraging customers to reduce their emissions by 80 percent. $^{76}$ The EIA has not yet been able to ascertain DuPont's current actual capacity or production of the chemical. However, available information suggests that sales of perfluorethane were probably less than 1,000 metric tons in 1994.7 Perfluoromethane $\left(\mathrm{CF}_{4}\right)$ is also produced commercially in small quantities. The EPA's Atmospheric Pollution Prevention Division believes that emissions of PFCs, HFC-23, and sulfur hexafluoride from the semiconductor industry totaled about 1 million metric tons carbon equivalent in 1994, with about 70 percent of GWP-weighted emissions caused by perfluoroethane. ${ }^{78}$ This is equivalent to emissions of about 300 metric tons of perfluoroethane and considerably smaller amounts of the other gases. The ELA is unable at present to assess trends in emissions of these chemicals used by the semiconductor industry.

PFC emissions are not regulated or reported, although their high GWPs $(6,900$ for perfluoromethane and 9,200 for perfluoroethane) have drawn the attention of the Climate Change Action Plan. As a byproduct of aluminum production, they arise during discrete periods of process inefficiency. Emissions could be reduced by improving process efficiency.

\section{Other Chemicals}

Several other chemicals combine both high GWPs and emissions levels to have a potential effect on global climate: carbon tetrachloride, methyl chloroform, chloroform, methylene chloride, and sulfur hexafluoride. Several of these chemicals are regulated under the Clean Air Act Amendments of 1990.

\section{Carbon Tetrachloride}

Carbon tetrachloride is a chemical whose uses have varied. Originally used as a household cleanser and dry-cleaning solvent, it was determined to be carcinogenic, and such uses were terminated. Most carbon tetrachloride is now used as a feedstock in the production of CFC-11 and CFC-12. Carbon tetrachloride is regulated by the Clean Air Act Amendments as a known carcinogen, and under the Montreal Protocol as an ozone-depleting chemical. Its production was phased

\footnotetext{
${ }^{74}$ U.S. Department of Energy, The Climate Change Action Plan: Technical Supplement, DOE/PO-0011 (Washington, DC, March 1994 ), p. 67.

${ }^{75}$ U.S. Department of Energy, Compliance Assessment of the Portsmouth Gaseous Diffusion Plant, DOE/EH-0144 (Washington, DC, April 1990), pp. 3-20-3-21.

76"DuPont Acts To Cut Perfluoroethane," Chemical Week (August 23, 1995), p. 34.

77"EPA Launches PFC Reduction Program," Chemical Week (July 31, 1996).

${ }^{78}$ U.S. Environmental Protection Agency, Office of Air and Radiation, Atmospheric Pollution Prevention Division, personal communication, August 29, 1996.
} 
out in January 1996. Much like CFCs, carbon tetrachloride has a high direct GWP $(1,400)$, which is completely offset by its indirect cooling effect of destroying ozone. Its net effect favors global cooling. ${ }^{79}$

Production and sales data have not been available in recent years. ${ }^{80}$ The TRI listed 1993 emissions of carbon tetrachloride at roughly 1,000 metric tons, up from 650 metric tons in $19922^{81}$ The TRI suggests that about 50 metric tons were recycled in 1993, down from nearly 160 metric tons in 1993. Estimates presented in Table 34 were developed using sales data and production data for CFC-11 and CFC-12. A rough approximation of emissions is determined by calculating (on a stoichiometric basis) the portion of total carbon tetrachloride sales that goes toward production of CFCs, and assuming that the rest is used as a solvent and consequently emitted to the atmosphere.

\section{Methyl Chloroform (1,1,1-Trichloroethane)}

Like carbon tetrachloride, methyl chloroform is regulated under the Clean Air Act Amendments as an ozone-depleting chemical covered by the Montreal Protocol. Primarily used as a solvent, it is required to be phased out by 1996. It has indirect cooling effects akin to carbon tetrachloride and the CFCs, but its GWP is only 110. As a result, its net effect is likely to promote global cooling. ${ }^{82}$ U.S. sales of methyl chloroform continued to decline in 1994, down to 166,000 metric tons. ${ }^{83}$ However, emissions as estimated by EPA declined even more rapidly, to 78,000 metric tons in 1994. This figure leaves about 88,000 metric tons of methyl chloroform unaccounted for. In 1994, the TRI reported emissions (presumably largely from manufacturers) of 17,000 metric tons, with recycling of 3,000 metric tons and disposals of 2,000 metric tons. ${ }^{84}$ Estimates of emissions are shown in Table 34.

\section{Chloroform}

Chloroform is used primarily as a feedstock for HCFC-22, with secondary use as a solvent. It is a fairly weak greenhouse gas with a GWP of 5 . Total emissions should be low, because most chloroform is incorporated into HCFC-22 during its production. As chloroform is a carcinogen, it is reported to the TRI. The TRI indicates that emissions have been decreasing and were only 5,200 metric tons in $1994 .{ }^{85}$

\section{Methylene Chloride (Dichloromethane)}

Like chloroform, methylene chloride is a weak greenhouse gas (GWP of 9). Its short atmospheric lifetime of less than 1 year probably prevents it from reaching the stratosphere where it would be damaging to ozone. As a result, its indirect cooling effects are likely to be quite small. A potential carcinogen, methylene chloride emissions are regulated and included in the TRI, with 1994 emissions of 29,000 metric tons, down significantly from 46,000 metric tons in $1990 .{ }^{86}$ The TRI indicates substantial activity in recycling and disposal, with about 9,000 metric tons recycled and 7,000 metric tons undergoing disposal in 1994.

\section{Sulfur Hexafluoride}

\begin{tabular}{|lc|}
\hline \multicolumn{2}{|c|}{ U.S. Emissions of Sulfur Hexafluoride, } \\
1990-1994 \\
…................................................................ \\
Estimated 1994 Emissions \\
(Million Metric Tons Carbon Equivalent)
\end{tabular}

Sulfur hexafluoride $\left(\mathrm{SF}_{6}\right)$ is used as an insulator for circuit breakers, switch gear, and other electrical equipment. In addition, its extremely low atmospheric concentration makes it a useful test gas for the calibration of gas concentration monitors. It is also a fugitive

\footnotetext{
${ }^{79}$ Intergovernmental Panel on Climate Change, Climate Change 1995: The Science of Climate Change (Cambridge, UK: Cambridge University Press, 1996), p. 119.

${ }^{80}$ Statistics are withheld to avoid disclosure of individual company operations. International Trade Commission, Synthetic Organic Chemicals 1993, USITC Publication 2810 (Washington, DC, November 1994), p. 3-18.

${ }^{81}$ U.S. Environmental Protection Agency, 1993 Toxics Release Inventory: Public Data Release (Washington, DC, March 1995), pp. 78-79.

${ }^{82}$ K.P. Shine, Y. Fouquart, V. Ramaswamy, S. Solomon, and J. Srinivasan, "Radiative Forcing," in Climate Change 1994: Radiative Forcing of Climate Change (Cambridge, UK: Cambridge University Press, 1995), p. 177.

${ }^{83}$ International Trade Commission, Synthetic Organic Chemicals 1994, USITC Publication 2810 (Washington, DC, 1995), p. 3-18.

${ }^{84}$ U.S. Environmental Protection Agency, 1994 Toxics Release Inventory: Public Data Release (Washington, DC, July 1996), pp. $284-285$.

${ }^{85}$ U.S. Environmental Protection Agency, 1994 Toxics Release Inventory: Public Data Release (Washington, DC, July 1996), p. 284.

${ }^{86}$ U.S. Environmental Protection Agency, 1994 Toxics Release Inventory: Public Data Release (Washington, DC, July 1996), p. 284.
} 
emission from certain semiconductor manufacturing processes.

Sulfur hexafluoride has a high GWP of 23,900 , but it is not produced or used in large quantities. In 1989, global production and emissions were estimated at 5,000 metric tons. ${ }^{87}$ The EPA estimates annual U.S. production of sulfur hexafluoride at 6,000 metric tons and emissions at about 1,000 metric tons annually. This is equivalent to emissions of more than 6 million metric tons of carbon.
The EPA's Atmospheric Pollution Prevention Division reports that sulfur hexafluoride is also used in small amounts in the semiconductor industry and also as a cover gas in magnesium manufacturing and die casting. ${ }^{88}$ The EPA estimates magnesium-related sulfur hexafluoride emissions at 1.2 million metric tons carbon equivalent, or about 200 metric tons of sulfur hexafluoride. The EIA is unable at present to assess trends in sulfur hexafluoride emissions from magnesium manufacture.

${ }^{87}$ M.K.W. Ko, N.D. Sze, W.C. Wang, G. Shia, A. Goldman, F.J. Murcray, D.G. Murcray, and.C.P. Rinsland, "Atmospheric Sulfur Hexafluoride: Sources, Sinks, and Greenhouse Warming," Journal of Geophysical Research, Vol. 98, p. 10,500.

${ }^{88}$ U.S. Environmental Protection Agency, Office of Air and Radiation, Atmospheric Póllution Prevention Division, personal communication, August 29, 1996. 
Table 31. Estimated 1994 Sales and Emissions of CFCs and Other Greenhouse Gases (Thousand Metric Tons)

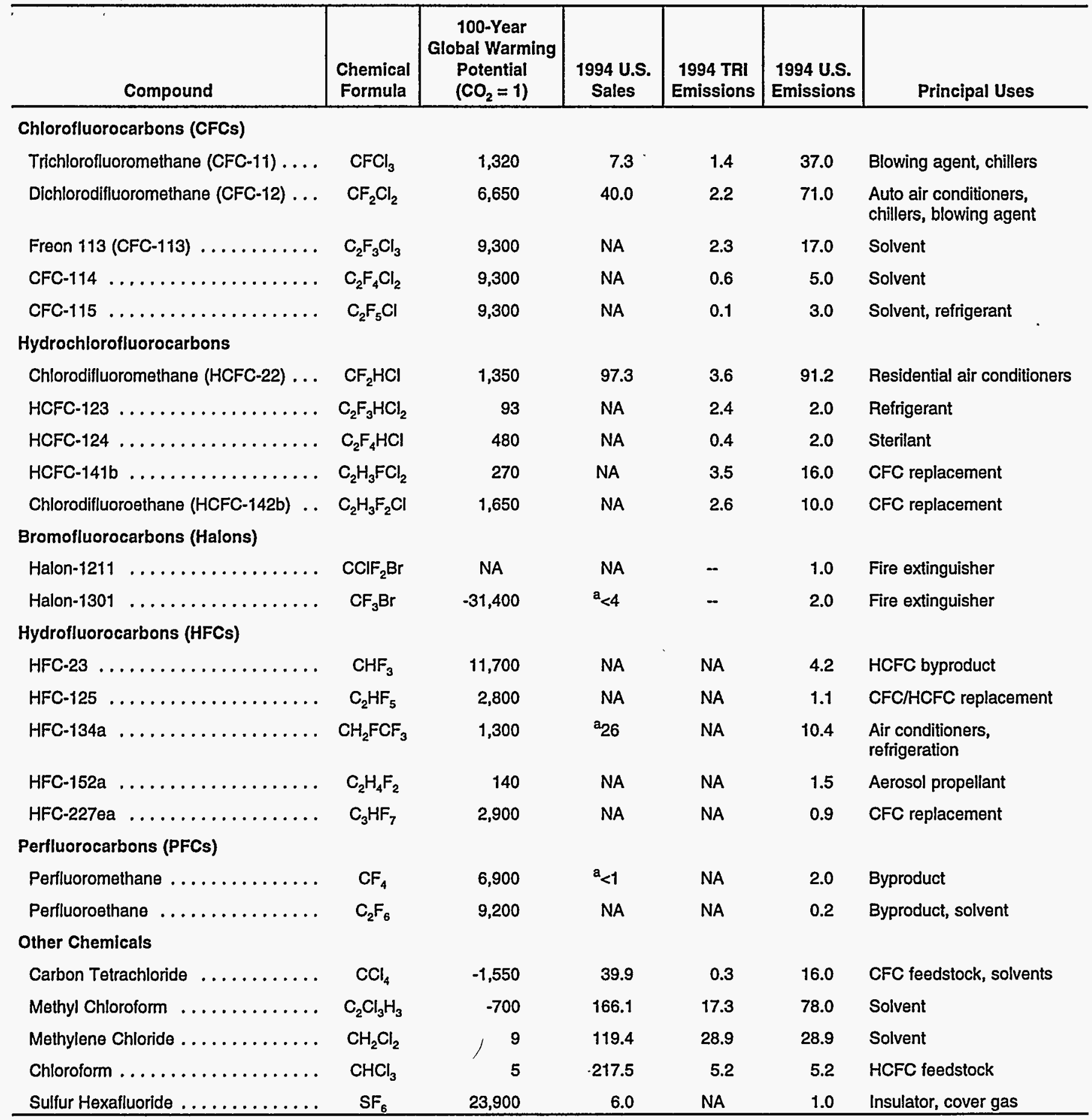

aEIA estimate.

$\mathrm{NA}=$ not available. $\cdots=$ less than 500 metric tons.

Sources: Chemical formulae and global warming potentials from Intergovernmental Panel on Climate Change, Climate Change 1995: The Science of Climate Change (Cambridge, UK: Cambridge University Press, 1996), pp. 119 and 121. Production and sales of CFCs and other chemicals from International Trade Commission, Synthetic Organic Chemicals: United States Production and Sales, 1994 (Washington, DC, 1995). TRI emissions from U.S. Environmental Protection Agency, 1994 Toxics Release Inventory: Public Data Release, EPA-745-R-94-001 (Washington, DC, June 1996), p. 73. Estimated 1994 U.S, emissions from U.S. Environmental Protection Agency, Inventory of U.S. Greenhouse Gas Emissions and Sinks, 19901994, EPA-230-R-96-006 (Washington, DC, November 1995), pp. 37-40. 
Table 32. Estimated U.S. Emissions of Halocarbons and Miscellaneous Greenhouse Gases, 1988-1995 (Thousand Metric Tons of Gas)

\begin{tabular}{|c|c|c|c|c|c|c|c|c|}
\hline Gas & 1988 & 1989 & 1990 & 1991 & 1992 & 1993 & 1994 & P1995 \\
\hline CFC-11 $\ldots \ldots \ldots \ldots \ldots \ldots$ & 85 & 80 & 60 & 54 & 48 & 39 & 37 & 8 \\
\hline CFC-113 $\ldots \ldots \ldots \ldots \ldots \ldots$ & 83 & 78 & 50 & 39 & 28 & 20 & 17 & 6 \\
\hline Other CFCs $\ldots \ldots \ldots \ldots \ldots \ldots$ & NA & NA & 9 & 9 & 9 & 8 & 8 & 7 \\
\hline $\begin{array}{l}\text { Halons . . . . . . . . . . . . . . . . . } \\
\text { Hydrochlorofluorocarbons (HCFCs) }\end{array}$ & \multicolumn{7}{|c|}{ Hydrochlorofluorocarbons (HCFCs) } & 2 \\
\hline HCFC-22 $\ldots \ldots \ldots \ldots \ldots \ldots \ldots$ & 74 & 76 & 82 & 82 & 86 & 89. & 91 & 91 \\
\hline HCFC-141b ............ & 0 & 0 & 0 & 1 & 3 & 8 & 16 & 21 \\
\hline HCFC-142b $\ldots \ldots \ldots \ldots \ldots \ldots$ & 0 & 0 & 0 & 3 & 3 & 6 & 10 & 16 \\
\hline Other HCFCs $\ldots \ldots \ldots \ldots \ldots . \ldots$ & NA & NA & 2 & 3 & 3 & 4 & 4 & 8 \\
\hline \multicolumn{9}{|l|}{ Hydrofluorocarbons (HFCs) } \\
\hline Perfluorocarbons (PFCs) . . . . . . . & 3 & 3 & 3 & 3 & 3 & 2 & 2 & 2 \\
\hline \multicolumn{9}{|l|}{ Other Chemicals } \\
\hline Carbon Tetrachloride .. & NA & NA & 30 & NA & 26 & 22 & 16 & NA \\
\hline Methyl Chloroform $\ldots \ldots \ldots \ldots$ & 323 & 296 & 316 & 224 & 215 & 122 & 78 & 32 \\
\hline Sulfur Hexafluoride . . . . . . . . . & NA & NA & 1 & 1 & 1 & 1 & 1 & 1 \\
\hline
\end{tabular}

$P=$ preliminary data. $N A=$ not available.

Sources: 1990 and 1994 emissions estimates from U.S. Environmental Protection Agency, Inventory of Greenhouse Gas Emissions and Sinks, 1990-1994, EPA-230-R-96-006 (Washington, DC, November 1995), pp. 46-50. Other years estimated from methods described in Appendix A. 


\section{Criteria Pollutants}

\section{Overview}

\begin{tabular}{|c|c|c|c|c|}
\hline \multicolumn{5}{|c|}{$\begin{array}{l}\text { U.S. Emissions of Criteria Pollutants, } \\
\text { 1990-1994 }\end{array}$} \\
\hline \multirow[b]{2}{*}{ Source } & \multicolumn{2}{|c|}{$\begin{array}{l}\text { Million Metric } \\
\text { Tons of Gas }\end{array}$} & \multicolumn{2}{|c|}{$\begin{array}{l}\text { Percent } \\
\text { Change }\end{array}$} \\
\hline & 1990 & 1994 & $\begin{array}{l}1990- \\
1994\end{array}$ & $\begin{array}{r}1993- \\
1994\end{array}$ \\
\hline Carbon Monoxide & 91.2 & 88.9 & -2.6 & 4.1 \\
\hline Nitrogen Oxides & 20.9 & 21.4 & 2.5 & 1.4 \\
\hline $\begin{array}{l}\text { Nonmethane } \\
\text { Volatile Organic } \\
\text { Compounds }\end{array}$ & 21.4 & 21.0 & -1.8 & 2.7 \\
\hline
\end{tabular}

This chapter presents emissions estimates for the criteria pollutants carbon monoxide, nitrogen oxides, and nonmethane volatile organic compounds (NMVOCs). ${ }^{89}$ Although these gases are not considered to be greenhouse gases themselves, estimates are presented here because of their indirect impact on atmospheric concentrations of carbon dioxide, methane, and ozone.

The Clean Air Act of 1970 required that air quality standards be established for pollutants that have adverse effects on public health or welfare. These are termed "criteria pollutants" because the EPA based each National Ambient Air Quality Standard (NAAQS), on health-based criteria from scientific studies. This report includes emissions estimates for carbon monoxide $(\mathrm{CO})$, nitrogen oxides $\left(\mathrm{NO}_{\mathrm{x}}\right)$, and nonmethane volatile organic compounds (NMVOCs), which are criteria pollutants that influence the atmospheric concentrations of greenhouse gases, including carbon dioxide, methane, and ozone.
Ozone is produced largely from atmospheric chemical reactions involving these criteria pollutants. While stratospheric ozone absorbs harmful ultraviolet solar radiation, ozone in the troposphere exhibits the greenhouse properties that warm the Earth's surface. The temperature differential between the radiation absorbed by stratospheric ozone and the radiation redirected to the Earth's surface by tropospheric ozone determines the magnitude of ozone's greenhouse effect. Ozone is highly reactive with other atmospheric gases, and its concentration is influenced by meteorological conditions. As a result, it remains in the troposphere for only hours or days. Hence, concentrations of tropospheric ozone tend to be centered around cities where high levels of criteria pollutants are found. Ozone concentrations are measured at individual urban sites throughout the United States. The EPA reports that the composite average ozone concentration for its 532 U.S. testing sites has declined by 12 percent since $1984 .^{90}$

The EPA Office of Air Quality Planning and Standards has compiled emissions data for the various criteria pollutants in the document National Air Pollutant Emission Trends, 1900-1994. ${ }^{91}$ The emissions estimates in this report are based on that document. The EPA continues to modify emissions data with improved estimation methods and updated information.

Since the passage of the Clean Air Act of 1970 and subsequent amendments, implementation of pollution control measures and replacement of older, less fuelefficient vehicles have restrained potential growth in criteria pollutant emissions that otherwise would have been expected from growth in the economy, increased driving, and expansion of industrial output. In short, emissions of both carbon monoxide and NMVOCs are currently significantly below peak levels seen in the early 1970s despite year-to-year fluctuations. Although emissions of nitrogen oxide are now higher than in

\footnotetext{
${ }^{89}$ All estimates and projections presented in this chapter are taken directly from Environmental Protection Agency (EPA), National Air Pollutant Emission Trends, 1900-1994, EPA-454/R-95-011 (Washington, DC, October 1995). See: http://www.epa.gov/oar/emtrnd94/ emtrnd94.html.

${ }^{90}$ U.S. Environmental Protection Agency, Office of Air Quality Planning and Standards, National Air Quality and Emissions Trends Report, 1993 (Research Triangle Park, NC, October 1994), p. 43.

${ }^{91}$ U.S. Environmental Protection Agency, Office of Air Quality Planning and Standards, National Air Pollutant Emission Trends, 1900-1994, EPA-454/R-95-011 (Research Triangle Park, NC, October 1995).
} 
1970 , the level of emissions has been relatively stable in the 1990s (Table 33). Trends for each source are discussed individually, as follows.

\section{Carbon Monoxide}

\begin{tabular}{|c|c|}
\hline \multicolumn{2}{|c|}{ U.S. Carbon Monoxide Emissions, 1990-199 } \\
\hline $\begin{array}{l}\text { Estimated } 1994 \text { Emissions } \\
\text { (Million Metric Tons of Gas) }\end{array}$ & 88.85 \\
\hline $\begin{array}{l}\text { Change Compared to } 1993 \\
\text { (Million Metric Tons of Gas) }\end{array}$ & 3.52 \\
\hline Change from 1993 (Percent) & 4.1 \\
\hline $\begin{array}{l}\text { Change Compared to } 1990 \\
\text { (Million Metric Tons of Gas) }\end{array}$ & -2.39 \\
\hline Change from 1990 (Percent) & -2.6 \\
\hline
\end{tabular}

Most emissions of carbon monoxide result from incomplete oxidation during combustion of fuels used for transportation (Table 34). Transportation emissions, primarily from highway vehicles, accounted for about 78 percent of 1994 emissions. Total emissions in 1994 amounted to about 89 million metric tons, an amount considerably below the peak of roughly 115 million metric tons seen in the early 1970s. Between 1993 and 1994 carbon monoxide emissions increased by 4.1 percent, largely due to a doubling in emissions from forest wildfires. Otherwise 1994 emissions were generally below 1990 levels except for "other off-highway" vehicles, which are not as well controlled as other sources. Carbon monoxide emissions are expected to decrease through the year 2000 as a result of more stringent tailpipe standards and other factors.

\section{Nitrogen Oxides}

Nitrogen oxide emissions are related to air-fuel mixes and combustion temperatures during the burning of fuels. Emissions are reduced by the deployment of pollution control equipment, such as catalytic converters. Since 1980 total U.S. emissions of nitrogen oxides have hovered around 21 million metric tons per year (Table 35). Although this does not represent a decline (as seen with the other criteria pollutants), it is much lower than the rate of growth in fuel consumption (such as consumption of gasoline by motorists and coal by electric utilities). Emissions are split between transportation and stationary sources. Although recent

\section{U.S. Emissions of Nitrogen Oxides, 1990-1994}

\begin{tabular}{lc} 
Estimated 1994 Emissions & \\
(Million Metric Tons of Gas) & 21.41 \\
\hline $\begin{array}{c}\text { Change Compared to } 1993 \\
\text { (Million Metric Tons of Gas) }\end{array}$ & 0.30 \\
\hline Change from 1993 (Percent) & 1.4 \\
\hline Change Compared to 1990 & 0.52 \\
\hline (Million Metric Tons of Gas) & 2.5 \\
\hline Change from 1990 (Percent) & \\
\hline
\end{tabular}

levels are about the same as in 1990, they are nearly 15 percent greater than levels in the early 1970s. In the future, emissions are expected to decline with implementation of various additional emissions control measures.

\section{Nonmethane Volatile Organic Compounds}

\begin{tabular}{|c|c|}
\hline \multicolumn{2}{|c|}{$\begin{array}{l}\text { U.S. Emissions of Nonmethane Volatile } \\
\text { Organic Compounds, 1990-1994 }\end{array}$} \\
\hline $\begin{array}{l}\text { Estimated } 1994 \text { Emissions } \\
\text { (Million Metric Tons of Gas) }\end{array}$ & 21.01 \\
\hline $\begin{array}{l}\text { Change Compared to } 1993 \\
\text { (Million Metric Tons of Gas) }\end{array}$ & 0.54 \\
\hline Change from 1993 (Percent) & 2.7 \\
\hline $\begin{array}{l}\text { Change Compared to } 1990 \\
\text { (Million Metric Tons of Gas) }\end{array}$ & -0.39 \\
\hline Change from 1990 (Percent) & -1.8 \\
\hline
\end{tabular}

Nonmethane volatile organic compounds (NMVOCs) are a principal component in the chemical and physical atmospheric reactions that form ozone and other photochemical oxidants. Nearly half of NMVOC emissions come from industrial processes (Table 36), of which solvent use is the largest. Most of the remaining emissions are from combustion of transportation fuels. Emissions of NMVOCs declined by some 24 percent from 1970 through the 1990 s, while fuel consumption in the transportation sector increased and activity in the industrial sector expanded. This improvement was 
accomplished by some reformulation of petroleum products, implementation of pollution abatement measures, and changes in industrial processes. Emissions from solvent utilization declined due to the substitution of water-based emulsified asphalt for asphalt liquefied with petroleum distillates.

Emissions of NMVOCs amounted to about 21 million metric tons in 1994, up by 2.7 percent over 1993. Even though both transportation and industrial sources showed increases in 1993, total emissions were modest- ly lower than in 1990. Emissions are expected to decline through the year 2000, although the rate of decline will be limited as fleet turnover progressively results in a greater share of vehicles being operated with emission controls in place and lower emitting industrial processes are more widely used. As for the criteria pollutants as a group, these forecasts are based on existing law and regulations scheduled to come into effect. They do not take into account the possible outcome of more stringent measures that have been proposed and are not yet law, but which will likely affect the future. 
Table 33. U.S. Emissions of Criteria Pollutants, 1988-1995 (Million Metric Tons of Gas)

\begin{tabular}{|c|c|c|c|c|c|c|c|c|}
\hline Source & 1988 & 1989 & 1990 & 1991 & 1992 & 1993 & 1994 & 1995 \\
\hline Carbon Monoxide & 105.0 & 93.5 & 91.2 & 88.3 & 85.3 & 85.3 & 88.9 & NA \\
\hline Nitrogen Oxides & 21.4 & 21.1 & 20.9 & 20.6 & 20.7 & 21.1 & 21.4 & NA \\
\hline Nonmethane VOCs ...... & 23.3 & 21.7 & 21.4 & 20.7 & 20.3 & 20.5 & 21.0 & NA \\
\hline
\end{tabular}

$\mathrm{NA}=$ not available.

Note: Data in this table are revised from the data contained in the previous EIA report, Emissions of Greenhouse Gases in the United States 1987-1994, DOE/EIA-0573(87-94) (Washington, DC, October 1995).

Source: U.S. Environmental Protection Agency, Office of Air Quality Planning and Standards, National Air Pollutant Emission Trends, 1900-1994, EPA-454/R-95-011 (Research Triangle Park, NC, October 1995), pp. A-2-A-6.

Table 34. U.S. Carbon Monoxide Emissions, 1988-1995 (Million Metric Tons)

\begin{tabular}{|c|c|c|c|c|c|c|c|c|}
\hline Source & 1988 & 1989 & 1990 & 1991 & 1992 & 1993 & 1994 & 1995 \\
\hline \multicolumn{9}{|l|}{ Transportation } \\
\hline Highway Vehicles. & 64.47 & 59.91 & 57.01 & 56.30 & 54.29 & 54.60 & 55.39 & NA \\
\hline Aircraft $\ldots \ldots \ldots \ldots \ldots \ldots \ldots \ldots$ & 0.84 & 0.87 & 0.88 & 0.87 & 0.89 & 0.92 & 0.96 & NA \\
\hline Railroads $\ldots \ldots \ldots \ldots \ldots \ldots \ldots$ & 0.11 & 0.11 & 0.11 & 0.11 & 0.11 & 0.11 & 0.11 & NA \\
\hline$\ldots \ldots \ldots \cdots \cdots \cdots$ & 0.05 & 0.05 & 0.05 & 0.05 & 0.05 & 0.06 & 0.06 & NA \\
\hline Other Off-Highway ..... & 12.15 & 12.14 & 12.24 & 12.21 & 12.46 & 12.76 & 13.07 & NA \\
\hline Total $\ldots \ldots \ldots \ldots \ldots \ldots \ldots \ldots$ & 77.62 & 73.08 & 70.29 & 69.54 & 67.81 & 68.45 & 69.59 & NA \\
\hline \multicolumn{9}{|l|}{ Stationary Source Fuel Combustion } \\
\hline Electric Utilities $\ldots \ldots \ldots \ldots \ldots \ldots$ & 0.28 & 0.29 & 0.28 & 0.29 & 0.28 & 0.29 & 0.29 & NA \\
\hline Industrial $\ldots \ldots \ldots \ldots \ldots \ldots \ldots$ & 0.61 & 0.61 & 0.61 & 0.60 & 0.61 & 0.61 & 0.61 & NA \\
\hline Commercial-Institutional & 0.07 & 0.07 & 0.07 & 0.07 & 0.07 & 0.08 & 0.08 & NA \\
\hline Residential . . . . . . . & 5.67 & 5.73 & 3.57 & 3.85 & 4.07 & 3.47 & 3.40 & NA \\
\hline Total $\ldots \ldots \ldots \ldots \ldots \ldots \ldots$ & 6.64 & 6.70 & 4.54 & 4.81 & 5.03 & 4.45 & 4.38 & NA \\
\hline Total Energy-Related Emissions ... & 84.26 & 79.77 & 74.84 & 74.35 & 72.84 & 72.90 & 73.97 & NA \\
\hline $\begin{array}{l}\text { Industrial Processes } \ldots \ldots \ldots \ldots \ldots \ldots \\
\text { Solid Waste Disposal }\end{array}$ & 4.74 & 4.78 & 4.74 & 4.64 & 4.71 & 4.79 & 4.91 & NA \\
\hline Incineration $\ldots .$. & 0.82 & 0.79 & 0.77 & 0.78 & 0.78 & 0.79 & 0.80 & NA \\
\hline Open Burning . . & 0.82 & 0.79 & 0.76 & 0.77 & 0.77 & 0.78 & 0.79 & NA \\
\hline Total $\ldots \ldots \ldots \ldots \ldots \ldots \ldots \ldots$ & 1.64 & 1.58 & 1.53 & 1.54 & 1.56 & 1.57 & 1.58 & NA \\
\hline Miscellaneous & & & & & & & & \\
\hline Forest Fires .. & 9.71 & 2.73 & 5.51 & 3.12 & 1.52 & 1.44 & 3.73 & NA \\
\hline Other Burning ..... & 4.67 & 4.64 & 4.62 & 4.62 & 4.63 & 4.64 & 4.65 & NA \\
\hline Total ............... & 14.39 & 7.37 & 10.13 & 7.74 & 6.14 & 6.08 & 8.39 & NA \\
\hline Total All Sources $\ldots \ldots \ldots \ldots \ldots$ & 105.03 & 93.50 & 91.24 & 88.27 & 85.25 & 85.33 & 88.85 & NA \\
\hline Carbon Content of Carbon Monoxide .. & 45.01 & 40.07 & 39.10 & 37.83 & 36.54 & 36.57 & 38.08 & NA \\
\hline $\begin{array}{l}\text { Carbon Content of Energy-Related } \\
\text { Carbon Monoxide } \ldots \ldots \ldots \ldots \ldots\end{array}$ & 36.12 & 34.20 & 32.08 & 31.87 & 31.22 & 31.25 & 31.71 & NA \\
\hline
\end{tabular}

$\mathrm{NA}=$ not available.

Note: Data in this table are revised from the data contained in the previous EIA report, Emissions of Greenhouse Gases in the United States 1987-1994, DOE/EIA-0573(87-94) (Washington, DC, October 1995).

Source: U.S. Environmental Protection Agency, Office of Air Quality Planning and Standards, National Air Pollutant Emission Trends, 1900-1994, EPA-454/R-95-011 (Research Triangle Park, NC, October 1995), Table A-1, pp. A-2-A-5. 
Table 35. U.S. Nitrogen Oxide Emissions, 1988-1995 (Million Metric Tons)

\begin{tabular}{|c|c|c|c|c|c|c|c|c|}
\hline Source & 1988 & 1989 & 1990 & 1991 & 1992 & 1993 & 1994 & 1995 \\
\hline \multicolumn{9}{|l|}{ Transportation } \\
\hline Highway Vehicles & 6.95 & 6.97 & 6.79 & 6.69 & 6.75 & 6.81 & 6.83 & NA \\
\hline Aircraft...$\ldots \ldots \ldots$ & 0.12 & 0.13 & 0.13 & 0.13 & 0.13 & 0.13 & 0.14 & NA \\
\hline$\ldots \ldots \ldots \ldots \ldots \ldots \ldots$ & 0.81 & 0.84 & 0.84 & 0.84 & 0.86 & 0.86 & 0.86 & NA \\
\hline Vessels & 0.15 & 0.16 & 0.16 & 0.16 & 0.16 & 0.17 & 0.17 & NA \\
\hline Other Off-Highway & 1.56 & 1.46 & 1.45 & 1.41 & 1.47 & 1.55 & 1.64 & NA \\
\hline Total $\ldots \ldots \ldots \ldots \ldots$ & 9.59 & 9.55 & 9.37 & 9.22 & 9.36 & 9.52 & 9.64 & NA \\
\hline \multicolumn{9}{|l|}{ Stationary Source Fuel Combustion } \\
\hline Electric Utilities $\ldots \ldots \ldots \ldots \ldots \ldots$ & 6.83 & 6.90 & 6.82 & 6.79 & 6.78 & 7.05 & 7.07 & NA \\
\hline Industrial & 2.89 & 2.91 & 2.95 & 2.88 & 2.92 & 2.90 & 2.91 & NA \\
\hline Commercial-Institutional & 0.28 & 0.27 & 0.27 & 0.27 & 0.28 & 0.28 & 0.28 & NA \\
\hline Residential . & 0.38 & 0.38 & 0.36 & 0.37 & 0.38 & 0.37 & 0.37 & NA \\
\hline Total $\ldots \ldots \ldots \ldots \ldots \ldots \ldots \ldots$ & 10.38 & 10.47 & 10.41 & 10.31 & 10.35 & 10.60 & 10.63 & NA \\
\hline Total Energy-Related Emissions ... & 19.97 & 20.01 & 19.78 & 19.54 & 19.71 & 20.12 & 20.26 & NA \\
\hline $\begin{array}{l}\text { Industrial Processes } \ldots \ldots \ldots \ldots \ldots \ldots \\
\text { Solid Waste Disposal }\end{array}$ & 0.70 & 0.70 & 0.70 & 0.68 & 0.70 & 0.71 & 0.73 & NA \\
\hline Incineration & 0.03 & 0.03 & 0.03 & 0.03 & 0.03 & 0.03 & 0.03 & NA \\
\hline Open Burning ... & 0.05 & 0.05 & 0.05 & 0.05 & 0.05 & 0.05 & 0.05 & NA \\
\hline $\begin{array}{l}\text { Total } \ldots \ldots \ldots \ldots \ldots \ldots \ldots \ldots \\
\text { Miscellaneous }\end{array}$ & 0.08 & 0.08 & 0.07 & 0.08 & 0.08 & 0.08 & 0.08 & NA \\
\hline Forest Fires & - & * & * & * & $\star$ & * & - & NA \\
\hline Other Burning $\ldots \ldots \ldots \ldots$. & 0.66 & 0.26 & 0.34 & 0.26 & 0.23 & 0.20 & 0.34 & NA \\
\hline Total $\ldots \ldots \ldots \ldots \ldots \ldots \ldots \ldots \ldots$ & 0.66 & 0.27 & 0.34 & 0.26 & 0.23 & 0.20 & 0.34 & NA \\
\hline Total All Sources $\ldots \ldots \ldots \ldots \ldots \ldots$ & 21.41 & 21.05 & 20.88 & 20.55 & 20.71 & 21.10 & 21.41 & NA \\
\hline
\end{tabular}

*Less than 5,000 metric tons.

$\mathrm{NA}=$ not available.

Note: Data in this table are revised from the data contained in the previous EIA report, Emissions of Greenhouse Gases in the United States 1987-1994, DOE/EIA-0573(87-94) (Washington, DC, October 1995).

Source: U.S. Environmental Protection Agency, Office of Air Quality Planning and Standards, National Air Pollutant Emission Trends 1900-1994, EPA-454/R-95-011 (Research Triangle Park, NC, October 1995), Tables A-2, pp. A-6-A-9. 
Table 36. U.S. Emissions of Nonmethane Volatile Organic Compounds, 1988-1995 (Million Metric Tons)

\begin{tabular}{|c|c|c|c|c|c|c|c|c|}
\hline Source & 1988 & 1989 & $1990^{\circ}$ & 1991 & 1992 & 1993 & 1994 & 1995 \\
\hline \multicolumn{9}{|l|}{ Transportation } \\
\hline Highway Vehicles ... & 7.52 & 6.52 & 6.22 & 5.89 & 5.51 & 5.54 & 5.71 & NA \\
\hline Aircraft & 0.17 & 0.17 & 0.17 & 0.17 & 0.18 & 0.18 & 0.19 & NA \\
\hline Railroads & 0.04 & 0.04 & 0.04 & 0.04 & 0.04 & 0.04 & 0.04 & NA \\
\hline Vessels & 0.03 & 0.04 & 0.04 & 0.04 & 0.04 & 0.04 & 0.04 & NA \\
\hline Other Off-Highway & 1.67 & 1.66 & 1.67 & 1.68 & 1.71 & 1.74 & 1.77 & NA \\
\hline & \multicolumn{7}{|c|}{ Stationary Source Fuel Combustion } & NA \\
\hline Electric Utilities . & 0.03 & 0.03 & 0.03 & 0.03 & 0.03 & 0.03 & 0.03 & NA \\
\hline Industrial & 0.12 & 0.12 & 0.12 & 0.12 & 0.12 & 0.12 & 0.12 & NA \\
\hline Commercial-Institutional & 0.01 & 0.01 & 0.01 & 0.01 & 0.01 & 0.01 & 0.01 & NA \\
\hline Residential & 1.06 & 1.07 & 0.66 & 0.72 & 0.76 & 0.65 & 0.63 & NA \\
\hline Total $\ldots \ldots \ldots \ldots \ldots \ldots \ldots \ldots$ & 1.23 & 1.24 & 0.83 & 0.88 & 0.92 & 0.81 & 0.80 & NA \\
\hline Total Energy-Related Emissions ... & 10.66 & 9.67 & 8.97 & 8.70 & 8.39 & 8.35 & 8.55 & NA \\
\hline $\begin{array}{l}\text { Industrial Processes } \ldots \ldots \ldots \ldots \ldots \ldots \\
\text { Solid Waste Disposal }\end{array}$ & 9.46 & 9.38 & 9.41 & 9.32 & 9.46 & 9.60 & 9.78 & NA \\
\hline Incineration & 0.05 & 0.05 & 0.05 & 0.05 & 0.05 & 0.05 & 0.05 & NA \\
\hline Open Burning ... & 0.26 & 0.25 & 0.24 & 0.24 & 0.24 & 0.24 & 0.25 & NA \\
\hline Other & 1.78 & 1.78 & 1.76 & 1.76 & 1.76 & 1.76 & 1.76 & NA \\
\hline${ }_{\ldots} \ldots \ldots \ldots \ldots \ldots \ldots \ldots$ & 2.10 & 2.08 & 2.05 & 2.05 & 2.06 & 2.06 & 2.06 & NA \\
\hline \multicolumn{9}{|l|}{ Miscellaneous } \\
\hline Forest Fires & 0.83 & 0.30 & 0.70 & 0.40 & 0.15 & 0.19 & 0.34 & NA \\
\hline Other Burning . . . . & 0.28 & 0.27 & 0.27 & 0.27 & 0.27 & 0.27 & 0.28 & NA \\
\hline Total $\ldots \ldots \ldots \ldots \ldots \ldots \ldots \ldots$ & 1.11 & 0.58 & 0.97 & 0.67 & 0.42 & 0.47 & 0.62 & NA \\
\hline Total All Sources & 23.33 & 21.71 & 21.40 & 20.75 & 20.33 & 20.47 & 21.01 & NA \\
\hline
\end{tabular}

$\mathrm{NA}=$ not available.

Notes: Data in this table are revised from the data contained in the previous EIA report, Emissions of Greenhouse Gases in the United States 1987-1994, DOE/EIA-0573(87-94) (Washington, DC, October 1995). Totals may not equal sum of components due to independent rounding.

Source: U.S. Environmental Protection Agency, Office of Air Quality Planning and Standards, National Air Pollutant Emission Trends 1900-1994, EPA-454/R-95-011 (Research Triangle Park, NC, October 1995), Table A-3, pp. A-10-A-16. 


\section{Land Use Issues}

\section{Overview}

Emissions of carbon dioxide from the combustion of fossil fuels are dwarfed by carbon dioxide emissions and absorption from natural processes. As noted in Chapter 1, natural processes in the oceans and biomass are responsible for most carbon dioxide absorption and emissions. This is also true of methane and nitrous oxide. Most methane and nitrous oxide are created by bacteria in soils and wetlands. Although the most important natural processes affecting greenhouse gas concentrations in the atmosphere are not subject to human control, modifications in land use can influence their concentrations in significant ways.

The magnitude of the influence is difficult to measure. Unlike service station pumps, trees and swamps do not come equipped with meters. Thus, analysts can only estimate emissions or sequestration on the basis of small sample surveys and extrapolate (with associated uncertainty) to much larger regions. A second, related problem is distinguishing between human-caused and natural phenomena. An electric power plant is clearly a human artifact. Trees growing back over abandoned farmland are a more ambiguous case.

\section{Forests and the Carbon Budget}

The most important changes in land use affecting the carbon budget are those that increase or reduce forest land. Every year in the United States and throughout the world a very large amount of carbon dioxide, on the order of 100 billion metric tons, is removed from the atmosphere and sequestered into biomass. ${ }^{92}$ At the same time, carbon is released to the atmosphere from vegetative respiration, combustion of wood as fuel, degradation of manufactured wood products, and the natural decay of expired vegetation. The net numerical difference, or flux, between carbon sequestration and release can be viewed as a measure of the relative contribution of biomass to the carbon cycle. World flux is difficult to measure but is thought to be close to zero; in other words, sequestration and respiration are roughly in balance worldwide. ${ }^{93}$ In the United States, however, forests and the wood products produced from them sequestered a net of approximately 111 million metric tons of carbon ( 407 million metric tons of carbon dioxide) in 1992, including 12 million metric tons of carbon sequestered in wood products and 15 million metric tons of carbon sequestered in landfilled wood product waste. ${ }^{94}$ A further 127 million metric tons of carbon is believed to be sequestered in forest soils. Sequestered carbon offset 8 to 17 percent of the 1,381 million metric tons of carbon (or 5,068 million metric tons of carbon dioxide) emitted in the United States in 1992 from the burning of fossil fuels (see Chapter 2).

Estimates of carbon sequestration for years after 1992 are not currently available, but the U.S. Forest Service has made projections for 1993-1995 based on the assumption that historical trends before 1992 continued unchanged. These projections, which are 2 to 3 percent lower than the 1992 estimate, result in projected carbon sequestration in 1994 equivalent to approximately 12 percent of U.S. carbon dioxide emissions for that year. ${ }^{95}$

The current inventory of carbon in U.S. forests is enormous. A study by researchers Birdsey and Heath of the U.S. Forest Service estimated that U.S. forest ecosystems contained 54.6 billion metric tons of carbon in $1992^{96}$ - the equivalent of nearly 40 years of U.S. carbon emissions from fossil fuel consumption.

\footnotetext{
${ }^{92}$ Intergovernmental Panel on Climate Change, Greenhouse Gas Inventory Reference Manual, IPCC Guidelines for National Greenhouse Gas Inventories, Vol. 3 (Paris, France, 1995), p. 5.2.

${ }^{93}$ Intergovernmental Panel on Climate Change, Greenhouse Gas Inventory Reference Manual, IPCC Guidelines for National Greenhouse Gas Inventories, Vol. 3 (Paris, France, 1995), p. 5.2.

${ }^{94}$ R.A. Birdsey and L.S. Heath, "Carbon Changes in U.S. Forests," in L.A. Joyce (ed.), Productivity of America's Forests and Climate Change, General Technical Report RM-GTR-271 (Fort Collins, CO: USDA Forest Service, 1995).

${ }^{95}$ R.A. Birdsey and L.S. Heath, "Carbon Changes in U.S. Forests," in L.A. Joyce (ed.), Productivity of America's Forests and Climate Change, General Technical Report RM-GTR-271 (Fort Collins, CO: USDA Forest Service, 1995).

${ }^{96}$ R.A. Birdsey and L.S. Heath, "Carbon Changes in U.S. Forests," in L.A. Joyce (ed.), Productivity of America's Forests and Climate Change, General Technical Report RM-GTR-271 (Fort Collins, CO: USDA Forest Service, 1995).
} 


\section{New Sequestration Estimate}

Last year, the principal researchers on the topic of carbon sequestration in U.S. forests, Birdsey and Heath, published a new estimate of 238 million metric tons of carbon sequestered per year during the period 1987-1992. The EPA, in its examination of the carbon sequestration issue, elected to use Birdsey and Heath's estimates, excluding the most uncertain element, carbon sequestration in forest soils (called "dead flux" by Birdsey and Heath), which they estimated at 127 million metric tons annually.

There is a considerable body of forestry research, backed by a large body of data, on the amount of marketable timber produced by forests of various types. That research can be effectively harnessed to estimate the quantity of carbon incorporated into the wood of trees. The principal uncertainties are data uncertainties: it is a challenge to characterize accurately the 737 million acres of forest land in the United States (33 percent of the Nation's land area) in terms of tree species, stand age and height, etc., in order to apply tested forestry methods to an estimation of carbon sequestration.

Research on forest soils is much more sparse, and the characterization of 737 million acres of forest soil is more speculative than the characterization of the trees themselves. It seems more likely than not that significant quantities of carbon are sequestered in forest soils, but there are no reliable estimates of the actual amounts.

Carbon Flux in U.S. Forests, 1992

(Million Metric Tons)

\begin{tabular}{c|c}
\hline Item & $\begin{array}{c}\text { Estimated Carbon } \\
\text { Content }\end{array}$ \\
\hline Live Flux $\ldots \ldots \ldots \ldots \ldots \ldots$ & 84 \\
Wood Products $\ldots \ldots \ldots \ldots$ & 12 \\
Landfilled $\ldots \ldots \ldots \ldots \ldots$ & 15 \\
Dead Flux $\ldots \ldots \ldots \ldots \ldots$ & 127 \\
Total $\ldots \ldots \ldots \ldots$ & 235 \\
\hline
\end{tabular}

Source: R.A. Birdsey and L.S. Heath, "Carbon Changes in U.S. Forests," in L.A. Joyce (ed.), Productivity of America's Forests and Climate Change, General Technical Report RM-GTR-271 (Fort Collins, CO: USDA Forest Service, 1995).
Table 37 shows U.S. Department of Agriculture Economic Research Service estimates of the major uses of land in the United States, developed through a periodic sample survey that is updated every 5 years (the last update was 1992). The USDA publication that gives the most comprehensive view of land use, Major Uses of Land in the United States, indicates that between 1987 and 1992 there was a net increase of 6 million acres of forest land. ${ }^{97}$ Table 27 indicates that "Forest-Use Land" remained stable at 648 million acres between 1987 and 1992. However, "Special-Use Areas" include extensive forest land in the form of National Parks and wilderness areas. In 1992, forested "Special-Use Areas" accounted for nearly 89 million acres. As a result, forested land in the U.S. totals about 737 million acres.

The 737 million acres of forest land in the United States represents approximately two-thirds of the area that was forested in the year 1600 (1.04 billion acres)..$^{98}$ Figure 12 illustrates the extent of forest land in the coterminous United States in 1620, 1850, 1920, and 1992. Three important facts are highlighted by these maps. First, slightly less than 50 percent of the land area of the United States has historically contained forest, primarily because large areas of U.S. land are inhospitable to trees, limiting maximum potential carbon sequestration. Areas suitable for forest are concentrated primarily east of the Mississippi, in the Pacific Northwest, and in western Colorado. Second, very little of the extensive forest present in 1620 remained by 1920 , most having been cleared for agriculture and to produce timber; by 1920, the clearing of forests for agriculture had largely come to an end. Third, large areas returned to forest between 1920 and 1992, especially in the East where abandonment of agriculture set the stage for large-scale forest regrowth.

Aggregate annual carbon sequestration generally follows trends in forest cover, except when biomass density on forest lands changes dramatically, such as from either extensive timber harvesting (which results in forest land that sequesters relatively little carbon) or from a long-term lull in harvesting (which results in forest land that sequesters relatively large amounts of carbon).

The regrowth of U.S. forests has had important impacts on net U.S. carbon dioxide emissions. U.S. forests have been a net carbon sink since 1952. According to Forest Service researchers Richard Birdsey and Linda Heath, between 1952 and 1992, carbon stored on U.S. forest land increased by 11.3 billion metric tons, an average

\footnotetext{
${ }^{97}$ A. Daugherty, U.S. Department of Agriculture, Economic Research Service, Major Uses of Land in the United States: 1992, Agricultural Economic Report Number 723 (Washington, DC, September, 1995), p. 4.

${ }^{98}$ D.S Powell, J.L. Faulkner, D.R. Darr, Z. Zhu, and D.W. MacCleery, Forest Resources of the United States, 1992, USDA Forest Service General Technical Report RM-234 (Washington, DC, September 1993), p. 1.
} 
1620

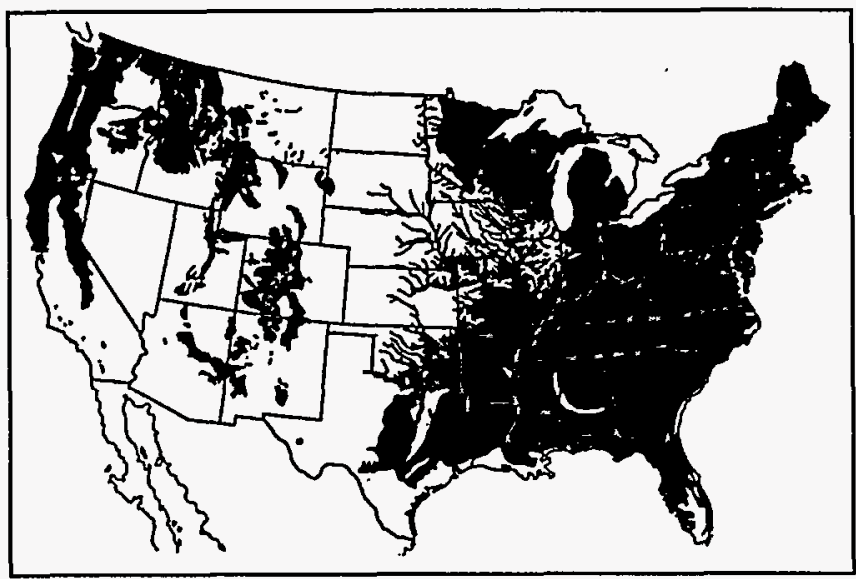

1920

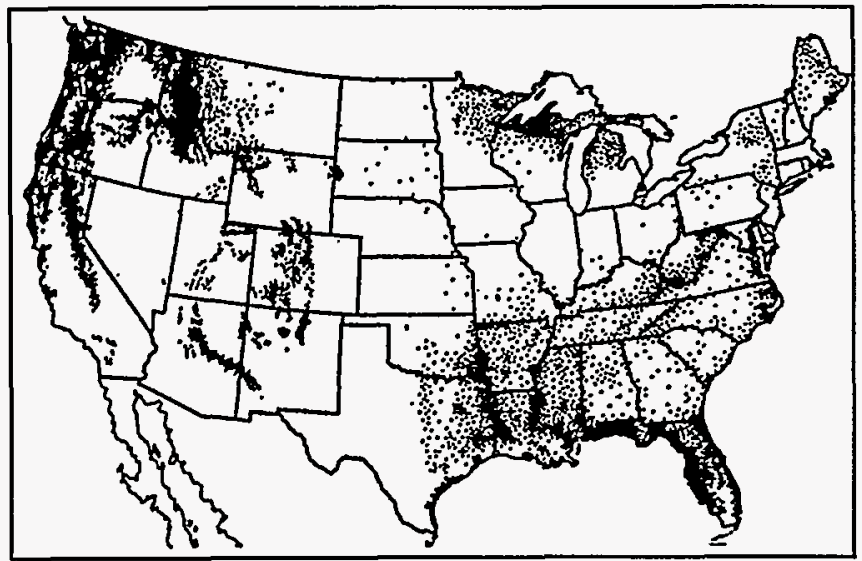

1850

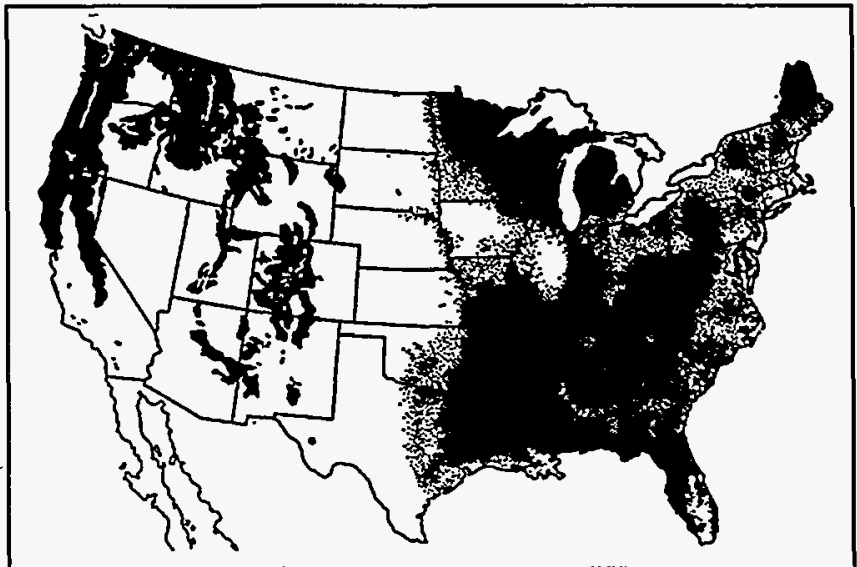

1992

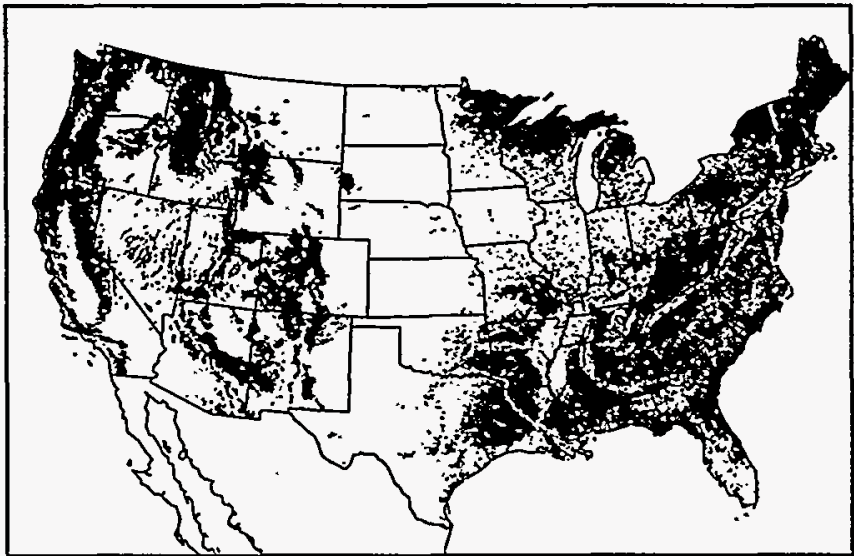

Notes: Maps for 1620,1850 , and 1920 represent estimates of the extent of virgin forest. They are presented as a surrogate for total forest cover because most of the forest clearing evident in the 1920 map occurred after 1850; thus, any forest present in 1920 but not indicated on that map would have been relatively young, secondary forest with a potential for future carbon sequestration roughly indistinguishable from that of young forests on newly cleared land.

Sources: 1620, 1850, 1920: W. Greeley, U.S. Forest Service, "The Relation of Geography to Timber Supply," Economic Geography, Vol. 1 (1925), p. 1. 1992: U.S. Department of Agriculture, Forest Service, AVHRR Forest Type Map, 1993 RPA Program, Forest Inventory and Analysis (Starkville, MS, December 1992), modified for printing by Pacific Meridian Resources (Emeryville, CA, 1996).

of 281 million metric tons per year, and an amount that offset approximately 25 percent of U.S. emissions of carbon for the period. ${ }^{99}$ In addition to reforestation associated with the abandonment of agriculture in the East, more than 4 million acres of marginal cropland have been reforested since 1974 under such Federal programs as the Conservation Reserve Program, Agricultural Conservation Program, and Forestry
Incentives Program. ${ }^{100}$ Birdsey and Heath estimated that U.S. forests will continue to be net carbon sinks well into the future, sequestering carbon at an average net annual rate of 177 million metric tons between 1992 and 2040 (not including sequestration into wood products and landfills), for a total increase in stored carbon of 8.5 billion metric tons. ${ }^{101}$

${ }^{99}$ R.A. Birdsey and L.S. Heath, "Carbon Changes in U.S. Forests," in L.A. Joyce (ed.), Productivity of America's Forests and Climate Change, General Technical Report RM-GTR-271 (Fort Collins, CO: USDA Forest Service, 1995).

${ }^{100}$ F.C. Cubbage, "Federal Land Conversion Programs," in Forests and Global Change, Vol. 1 (Washington, DC, 1992 ), p. 184.

${ }^{101}$ R.A. Birdsey and L.S. Heath, "Carbon Changes in U.S. Forests," in L.A. Joyce (ed.), Productivity of America's Forests and Climate Change, General Technical Report RM-GTR-271 (Fort Collins, CO: USDA Forest Service, 1995). 


\section{Cropland and the Carbon Budget}

It is difficult to be specific about how much carbon might be gained or lost through transformations of grasslands, pasturelands, or croplands. Although the amount of carbon in a square meter of forest might be on the order of 9 to 26 kilograms, depending on the condition of the forest and the age and type of trees growing, typical estimates of carbon storage in cultivated lands range from 1 to 8 kilograms per square meter, and estimates for uncultivated (but cultivatable) lands range from 2 to 10 kilograms per square meter. ${ }^{102}$ Thus, there is less carbon to be gained or lost, and the range of possible outcomes per unit of land is consequently smaller.

Between 1987 and 1992, the extent of cropland in use in the United States increased by 9 million acres, while the amount of idle cropland declined by 12 million acres. The shift from idled to cultivated and grazed cropland should, in principle, lead to small decreases in net carbon storage. Shifts from any of the above to urban land, the fastest single growth category, should lead to stable or slightly reduced storage. Land in urban areas, as measured by the Bureau of the Census, totaled 55.9 million acres in 1990, up from 47.3 million acres in $1980 . .^{103}$

\section{Methane Emissions from Wetlands}

The range of observed methane fluxes from U.S. wetlands is enormous. One survey of experiments conducted in the United States found estimates ranging from a negative flux (methane absorption) to a flux of 213 grams of methane per square meter per year, largely dependent on habitat type. ${ }^{104}$ Thus, it is difficult to extrapolate from experimental data to large-scale emissions estimates.
Estimates of global methane fluxes from wetlands tend to indicate that methane emissions from temperate-zone wetlands are minimal-typically between 5 and 10 million metric tons of methane per year for worldwide temperate-zone wetlands (which include U.S. wetlands) - when compared with estimated global wetlands emissions of 110 million metric tons. ${ }^{105}$ The U.S. share of all temperate-zone wetlands is about 57 percent, and U.S. wetlands lost during the 1980 s accounted for about 0.5 percent of the extent of wetlands at the beginning of the period. Consequently, the reduction in natural methane emissions from U.S. wetlands lost might be on the order of 10,000 to 20,000 metric tons annually over the decade.

\section{Effects of Land Use Changes on Methane and Nitrous Oxide Emissions}

The scientific literature suggests that grass and forest lands are both weak natural sinks for methane and weak natural sources for nitrous oxide, although adequate research to establish accurate estimates of aggregate methane and nitrous oxide emissions and sequestration is lacking. Natural soils apparently serve as methane sinks: well-aerated soils contain a class of bacteria called "methanotrophs" which use methane as food and oxidize it into carbon dioxide. Experiments indicate that cultivation reduces methane uptake by soils and increases nitrous oxide emissions. ${ }^{106}$ Exactly how much methane is absorbed by natural soils, and how much nitrous oxide is emitted, is difficult to estimate, although total amounts are very small.

It is known that conversion of forests and grasslands to cropland accelerates nitrogen cycling and increases nitrous oxide emissions from the soil. It is not known with certainty by, how much (see Appendix A). ${ }^{107}$.

\footnotetext{
${ }^{102}$ See the scattergram in L.K. Mann, “Changes in Soil Carbon Storage After Cultivation," Soil Science, Vol. 142, No. 5 (November 1986), p. 284.

${ }^{103}$ U.S. Department of Commerce, Bureau of the Census, 1990 Census of Population and Housing, Population and Housing Unit Counts, United States, CPH-2-1 (Washington, DC, 1993).

${ }^{104}$ See the scattergram in L.K. Mann, "Changes in Soil Carbon Storage After Cultivation," Soil Science, Vol. 142, No. 5 (November 1986), p. 284.

${ }^{105}$ See E. Matthews and I. Fung, "Methane Emissions from Natural Wetlands: Global Distribution, Area, and Environmental Characteristics," Global Biogeochemical Cycles, Vol. 1, No. 1 (March 1987); and K. Bartlett and R.C. Harriss, "Review and Assessment of Methane Emissions from Wetlands," Chemosphere, Vol. 26, Nos. 1-4 (1993), p. 280.

${ }^{106}$ A. Mosier et al., "Methane and Nitrous Oxide Fluxes in Native, Fertilized, and Cultivated Grasslands," Nature, Vol. 350, No. 6316 (March 28, 1991), pp. 330-332.

${ }^{107}$ A. Mosier, "Nitrous Oxide Emissions from Agricultural Soils," paper presented at RIVM International Workshop on Methane and Nitrous Oxide: Methods in National Emission Inventories and Options for Control (Amersfoort, The Netherlands, February 3-5, 1993).
} 
Table 37. Major Uses of Land in the United States (Million Acres)

\begin{tabular}{|c|c|c|c|c|}
\hline Land Use & 1978 & 1982 & 1987 & 1992 \\
\hline$\ldots \ldots \ldots \ldots \ldots \ldots$ & 471 & 469 & 464 & 460 \\
\hline$\ldots \ldots \ldots \ldots \ldots$ & 369 & 383 & 331 & 338 \\
\hline Idle Cropland $\ldots \ldots \ldots \ldots \ldots \ldots$ & 26 & 21 & 68 & 56 \\
\hline Pasture $\ldots \ldots \ldots \ldots \ldots \ldots$ & 76 & 65 & 65 & 67 \\
\hline Grassland Pasture and Range $\ldots . .$. & 587 & 597 & 591 & 591 \\
\hline Forest-Use Land . ............ & 703 & 655 & 648 & 648 \\
\hline Grazed Land $\ldots \ldots \ldots \ldots \ldots$ & 172 & 158 & 155 & 145 \\
\hline Other Use & 531 & 497 & 493 & 503 \\
\hline Special Use Areas & 158 & 270 & 279 & 281 \\
\hline Miscellaneous Other Land . ....... & 345 & 274 & 283 & 283 \\
\hline Total Land Area $\ldots \ldots \ldots \ldots \ldots$ & 2,264 & 2,265 & 2,265 & 2,263 \\
\hline
\end{tabular}

Sources: A. Daugherty, Major Uses of Land in the United States: 1987, Economic Research Service Report 643 (Washington, DC: U.S. Department of Agriculture, January 1991), p. 4; and A. Daugherty, Major Uses of Land in the United States: 1992, Agricultural Economic Report Number 723 (Washington, DC, September 1995), p. 4. 


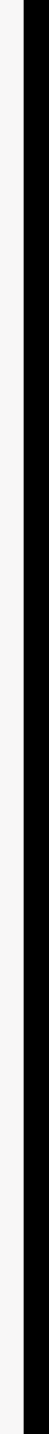




\section{Appendix A Estimation Methods}

The organization of this year's report differs from that of earlier reports in the series. Previously, the body of the report contained a discussion of estimated emissions of greenhouse gases, combined with a discussion of the methods used to estimate emissions. This year, information on emissions estimation methods have been compiled into this appendix. The organization of the appendix generally follows the organization of the body of this report: the discussion is divided by greenhouse gas and by emissions source.

\section{Carbon Dioxide}

Most U.S. anthropogenic carbon dioxide emissions come from energy consumption. Energy production contributes a small amount during the flaring of natural gas at oil and gas wells, and a number of industrial processes also emit carbon dioxide through noncombustion processes. The largest single source of emissions from these processes is the calcination of limestone in cement production. Other sources include lime manufacture, limestone and dolomite consumption, soda ash manufacture and consumption, industrial carbon dioxide manufacture and aluminum production. Lastly, some small adjustments are made to reach the total for national emissions. Each emissions source for carbon dioxide, the estimation method used, and the data sources are described here.

Several emissions sources are excluded from the carbon dioxide emissions presented in this report, either due to the uncertainty of estimates or because they are based on biomass combustion (which is assumed to be consumed sustainably with a net flux of carbon dioxide to the atmosphere equal to zero). Should the energy use of biomass fuels result in a long-term decline in the total carbon embodied in standing biomass (e.g., forests), the net release of carbon would be treated as a land use issue (see Chapter 7).

\section{Energy Consumption}

\section{Emissions Sources}

Most U.S. commercial energy is produced through the combustion of fossil fuels such as coal, natural gas, and petroleum. Chemically, the main components of fossil fuels are hydrocarbons, made up of molecules containing hydrogen and carbon atoms. When these fuels are burned, atmospheric oxygen combines with the hydrogen atoms to create water vapor, and with the carbon atoms to create carbon dioxide. In theory, if the amount of fuel burned and the amount of carbon in the fuel is known, the volume of carbon dioxide emitted into the atmosphere can be computed with a high degree of precision. In practice, however, a combination of realworld complexities can reduce the precision of the estimate. These complexities will be discussed further in this appendix. Nonetheless, energy-related carbon dioxide emissions are known with greater reliability than other greenhouse gas emissions sources, and the uncertainty in the estimate is probably 10 percent or less. Appendix C, "Uncertainty in Emissions Estimates," contains an extended discussion of the nature and sources of uncertainty in the estimates presented in this report.

One real-world complexity is that not all of the carbon in fuel is perfectly combusted. About 1.5 percent of the carbon in fossil fuels is emitted in the form of carbon monoxide, which swiftly decays into carbon dioxide in the atmosphere. Another 1 percent is emitted in the form of volatile organic compounds (including methane), which also eventually decay into carbon dioxide. The carbon dioxide emissions reported in Chapter 2 include all "potential" carbon dioxide emissions from the sources covered, including both carbon dioxide emitted directly and carbon emitted in other forms (such as carbon monoxide) that rapidly decay into carbon dioxide in the atmosphere.

\section{Estimation Method}

Carbon emissions in this report were calculated by multiplying energy consumption for each fuel type by an associated carbon emissions coefficient. The result was then modified by subtracting carbon sequestered by nonfuel use. This section describes the derivation of information on energy consumption, emissions coefficients, and carbon sequestered by nonfuel use.

\section{Consumption Data}

The Energy Information Administration (EIA) collects a wide variety of information from primary suppliers 
on a frequent basis and from energy consumers less often, but still in a timely manner. Thus, levels of energy consumption in the United States are fairly well known by end-use sector and detailed fuel type. ${ }^{108}$ To estimate carbon dioxide emissions, the EIA uses annual data from the four end-use sectors (residential, commercial, industrial, and transportation) and all of the fossil fuels (coal, natural gas, and the full slate of petroleum products). The petroleum products include asphalt and road oil, aviation gasoline, distillate fuel, jet fuel, kerosene, liquefied petroleum gases (LPGs), lubricants, motor gasoline, residential fuel, and other petroleum products. Definitions and chemical characteristics of the fossil fuels are documented in the Appendixes of the ELA's recurring reports: the Annual Energy Review (AER) and State Energy Data Report (SEDR), as well as Petroleum Supply Annual, Coal Industry Annual, and Natural Gas Annual. Using this approach to estimate emissions provides detailed information about trends in sources of emissions.

Information about consumption of "other petroleum" is derived from unpublished ELA data. In recent years, these products included crude oil, naphtha $<401^{\circ} \mathrm{F}$, other oil $\geq 401^{\circ} \mathrm{F}$, motor gasoline blending components, miscellaneous products, petroleum coke, pentanes plus, still gas, special naphthas, waxes, and unfinished oils.

\section{Emissions Coefficients}

The amount of carbon released when a fossil fuel is burned depends on the density, carbon content, and gross heat of combustion of the fuel. ${ }^{109}$ Most of the coefficients for major fuels are assumed to be constant over time. However, for motor gasoline, liquefied petroleum gases (LPG), jet fuel, and crude oil, EIA developed annualized carbon emissions coefficients to reflect changes in chemical composition or product mix over the years. Appendix B contains a more detailed discussion of the methodology for developing the coefficients. Table B1 presents a full listing of all factors for crude oil, natural gas, and the complete slate of petroleum products.

\section{Carbon Sequestration: Nonfuel Use of Fossil Fuels}

After energy consumption was multiplied by the emissions coefficients, carbon sequestered through nonfuel use was then deducted from gross carbon emissions. Estimates of nonfuel use of fossil fuels were based on data provided in EIA's Annual Energy Review 1995, Table 1.15. ${ }^{110}$ Table A1 lists nonfuel use of fossil fuels by type. Most nonfuel use occurs in the industrial sector. It accounted for about 5 quadrillion Btu, of consumption in 1995 (Table A1).

Not all nonfuel use of fossil fuels results in carbon sequestration. For example, natural gas (predominantly methane, or $\left.\mathrm{CH}_{4}\right)$ is used as a feedstock to make ammonia $\left(\mathrm{NH}_{4}\right)$. The carbon in the methane is reformed into carbon dioxide and emitted into the atmosphere. On the other hand, petrochemical feedstocks, such as ethane, are made into ethylene and then into polyethylene plastics and numerous other products. The carbon in these products ultimately is sequestered in landfills.

Ideally, nonfuel use of fossil fuels would be divided into its constituent applications, and each application would be studied to determine the ultimate fate of the carbon in the fossil fuel. Thus far it has not been possible to collect sufficient information to adopt such a detailed approach. Instead, the EIA uses the Intergovernmental Panel on Climate Change (IPCC) methods and information specific to U.S. industry to approximate how much carbon was sequestered by each product shown in Table A1. ${ }^{111}$ A "proportion of nonfuel use sequestered" was assumed for each product, usually based on IPCC recommendations but with EIA assumptions for those products for which no IPCC recommendation was available or for which more precise information could be obtained. These assumptions are shown in Table A2. The rationale for the assumptions is:

- Asphalt and Road Oil. All carbon in the 1.18 quadrillion Btu of asphalt and road oil was presumed to be sequestered.

\footnotetext{
${ }^{108}$ Although some of ELA's detailed sectoral surveys are only conducted every 3 years on a sample basis, the EIA collects information about apparent consumption of petroleum products (taken as "petroleum product supplied") in mandatory monthly surveys of primary suppliers (e.g., refiners, pipeline operators, importers/exporters, and bulk terminal operators).

${ }^{109}$ Combustion of hydrocarbons results in the production of carbon dioxide, water vapor, and heat. In the United States, the heat resulting from combustion is generally measured as the heat associated with production of water vapor and carbon dioxide. This is commonly referred to as the "higher" or "gross" heating.value and is used in EIA statistics on thermal energy. The estimates in this report consistently employ coefficients that reflect the higher heating value assumption. Internationally, however, the "lower" heating value is used. If the lower heating value were used, the Btu content of the fuel would be 5 to 10 percent lower, and the coefficients would be 5 to 10 percent larger, but the carbon emissions estimate would be unchanged. This is sometimes a source of discrepancy. See OECD, Estimation of Greenhouse Gas Emissions and Sinks (Final Report) (Paris, France, August 1991), pp. 2-12-2-15.

${ }^{110}$ This information is currently available only at the national level and for 1980-1994.

${ }^{11}$ For IPCC methodology see Intergovernmental Panel on Climate Change, Greenhouse Gas Inventory Reference Manual, IPCC Guidelines for National Greenhouse Gas Inventories, Vol. 3 (Paris, France, 1995), pp. 1.24-1.27.
} 
Table A1. U.S. Fossil Fuel Consumption for Nonfuel Use, 1988-1995

(Quadrillion Btu)

\begin{tabular}{|c|c|c|c|c|c|c|c|c|}
\hline End Use & 1988 & 1989 & 1990 & 1991 & 1992 & 1993 & 1994 & P1995 \\
\hline \multicolumn{9}{|l|}{ Petroleum } \\
\hline Asphalt and Road Oil & 1.14 & 1.10 & 1.09 & 1.08 & 1.10 & 1.15 & 1.17 & 1.18 \\
\hline Liquefied Petroleum Gases . ....... & 1.21 & 1.26 & 1.28 & 1.42 & 1.45 & 1.63 & 1.80 & 1.82 \\
\hline Lubricants ................. & 0.35 & 0.35 & 0.37 & 0.33 & 0.33 & 0.34 & 0.35 & 0.35 \\
\hline Industrial $\ldots \ldots \ldots \ldots \ldots \ldots$ & 0.18 & 0.18 & 0.19 & 0.17 & 0.17 & 0.17 & 0.18 & 0.18 \\
\hline Transportation $\ldots \ldots \ldots \ldots \ldots$ & 0.17 & 0.17 & 0.18 & 0.16 & 0.16 & 0.16 & 0.17 & 0.17 \\
\hline Petrochemical Feed ....... & 1.00 & 1.00 & 0.82 & 1.15 & 1.20 & 1.21 & 1.25 & 1.17 \\
\hline Petroleum Coke $\ldots \ldots \ldots \ldots \ldots$ & 0.15 & 0.14 & 0.19 & 0.16 & 0.26 & 0.18 & 0.20 & 0.20 \\
\hline Special Naphtha . . . . . . . & 0.11 & 0.11 & 0.11 & 0.09 & 0.10 & 0.10 & 0.08 & 0.07 \\
\hline Other (Waxes and Misc.) . . . . . . . . & 0.24 & 0.25 & 0.23 & 0.26 & 0.21 & 0.20 & 0.22 & 0.21 \\
\hline Coal $\ldots \ldots \ldots \ldots \ldots \ldots \ldots \ldots$ & 0.02 & 0.02 & 0.02 & 0.02 & 0.02 & 0.02 & 0.02 & 0.02 \\
\hline Natural Gas to Chemical Plants .... & 0.29 & 0.30 & 0.29 & 0.22 & 0.24 & 0.24 & 0.26 & 0.27 \\
\hline Total $\ldots \ldots \ldots \ldots \ldots \ldots \ldots \ldots$ & 4.51 & 4.53 & 4.41 & 4.74 & 4.91 & 5.07 & 5.35 & 5.28 \\
\hline
\end{tabular}

$P=$ preliminary data.

Notes: Asphalt and lubricants are as reported in the EIA's State Energy Data Report 1993, DOE/EIA-0214(93) (Washington, DC, July 1993) for 1988-1993, and Monthly Energy Review, DOE/EIA-0035(96/07) (Washington, DC, July 1996). Some slight differences exist between this table and the Annual Energy Review. Data in this table are revised from the data contained in the previous ElA report, Emissions of Greenhouse Gases in the United States 1987-1994, DOE/EIA-0573(87-94) (Washington, DC, October 1995).

Source: Energy Information Administration, Annual Energy Review 1995, DOE/EIA-0384(95) (Washington, DC, July 1996), Table 1.15, p. 33 , and underlying estimates.

- Liquefied Petroleum Gas. This use is derived from sales of LPG (i.e., ethane, propane, butane, isobutane, and pentanes plus) to the chemical industry. For this amount (approximately 1.82 quadrillion Btu), the EIA assumed that 80 percent of the carbon was sequestered. ${ }^{112}$

- Petrochemical Feedstocks. Petrochemical feedstocks include naphtha and other oils used as petrochemical feedstock, still gas not used as refinery fuel, and synthetic gas. Together, feedstocks accounted for about 1.2 quadrillion Btu of industrial energy consumption in 1995. Since most of these fuels are used to make products like plastic and rubber, in which carbon will be sequestered for long periods of time, the EIA assumed that 80 percent of the carbon in the feedstocks is sequestered.

- Natural Gas. Nonfuel use of natural gas is based on estimates of natural gas feedstocks supplied to the chemical industry to manufacture ammonia (for fertilizer) and other chemicals. This use was about 0.55 quadrillion Btu in 1995. All the natural gas used to manufacture ammonia was assumed to be oxidized during the production process, while the carbon in other chemicals was assumed to be sequestered. Since the mix of these products can change from year to year, the effective sequestration rate also varies. In earlier EIA reports, this was assumed to be a constant 33 percent, based on the general recommendations of the IPCC, but actually it ranges from 41 to 55 percent in the United States, depending on changes in production levels of ammonia and other chemicals.

To recapitulate, the quantity of nonfuel use of fossil fuels shown in Table A1 was multiplied by the emissions coefficients in Table $B 1$ and the proportion sequestered shown in Table A2 to determine the amount of carbon sequestered by nonfuel use. In 1995 nonfuel use of fossil fuels resulted in the sequestration of 2 million metric tons of carbon. The results for other recent years are shown in Chapter 2, Table 7.

\section{Carbon Sequestration: Fraction Combusted}

There is also a very small amount of carbon sequestration associated with the combustion of fossil fuels. Using IPCC assumptions, this report assumes that oxidation of liquid and solid fuels during combustion is 99 percent complete, and that 1 percent of the carbon remains sequestered. Oxidation of gaseous fuels (LPG

\footnotetext{
${ }^{112}$ For a discussion of nonfuel use assumptions for LPGs and petrochemical feedstocks see Intergovernmental Panel on Climate Change, Greenhouse Gas Inventory Reference Manual, IPCC Guidelines for National Greenhouse Gas Inventories, Vol. 3 (Paris, France, 1995), pp. 1.241.27.
} 
Table A2. Rates of Sequestration for U.S. Fossil Fuel Consumption

\begin{tabular}{|c|c|c|}
\hline Fuel Type & $\begin{array}{c}\text { Fraction } \\
\text { of Fuel } \\
\text { Combusted } \\
\end{array}$ & $\begin{array}{c}\text { Fraction } \\
\text { of Nonfuel } \\
\text { Use of Energy } \\
\text { Sequestered } \\
\end{array}$ \\
\hline \multicolumn{3}{|l|}{ Petroleum } \\
\hline Motor Gasoline & 0.99 & -- \\
\hline LPG $\ldots \ldots \ldots$ & 0.995 & 0.8 \\
\hline Jet Fuel & 0.99 & -- \\
\hline Distillate Fuel ......... & 0.99 & -- \\
\hline Residual Fuel & 0.99 & -- \\
\hline Asphalt and Road Oil .... & 0.99 & 1.0 \\
\hline Lubricants ........... & $0.99^{\prime}$ & 0.5 \\
\hline Petrochemical Feed ..... & 0.99 & 0.8 \\
\hline Aviation Gas .......... & 0.99 & - \\
\hline Kerosene ........... & 0.99 & -- \\
\hline Petroleum Coke ....... & 0.99 & 0.5 \\
\hline Special Naphtha . . . . . . . . & 0.99 & 0 \\
\hline \multicolumn{3}{|l|}{ Other } \\
\hline Aviation Gas & & \\
\hline Blending Components .... & 0.99 & -. \\
\hline Crude Oil $\ldots \ldots \ldots \ldots$ & 0.99 & - \\
\hline Naphtha $<401^{\circ} \mathrm{F} \ldots \ldots \ldots$ & 0.99 & 0.8 \\
\hline $\begin{array}{l}\text { Other Oil } \geq 401^{\circ} \mathrm{F} \ldots \ldots \\
\text { Petrochemical Feed }\end{array}$ & 0.99 & 0.8 \\
\hline $\begin{array}{l}\text { Still Gas .............. } \\
\text { Motor Gasoline }\end{array}$ & 0.99 & -- \\
\hline Blending Components & 0.99 & -- \\
\hline Miscellaneous . . . . . . . . & 0.99 & 1.0 \\
\hline Natural Gasoline ........ & 0.99 & -- \\
\hline Plant Condensate ....... & 0.99 & -- \\
\hline Pentanes Plus $\ldots . . . \ldots$ & 0.99 & -- \\
\hline Still Gas . . & 0.99 & -- \\
\hline Special Naphthas .. & 0.99 & 0 \\
\hline Unfinished Oils . . . . . . . & 0.99 & -- \\
\hline Unfractionated Stream ... & 0.99 & -- \\
\hline Waxes...$\ldots \ldots$. . & 0.99 & 1.0 \\
\hline \multicolumn{3}{|l|}{ Coal } \\
\hline Residential and Commercial & 0.99 & -- \\
\hline Industrial Coking . . . . . . . & 0.99 & 0.75 \\
\hline Industrial Other . . . . . . . & 0.99 & -- \\
\hline Electric Utility . . & 0.99 & -- \\
\hline Natural Gas & & \\
\hline Flare Gas . & 1.00 & -- \\
\hline Natural Gas & 0.995 & $0.41-0.55$ \\
\hline Crude Oil $\ldots \ldots \ldots \ldots \ldots$ & 0.99 & - \\
\hline
\end{tabular}

Sources: EIA estimates documented in this chapter; and Intergovernmental Panel on Climate Change, Greenhouse Gas Inventory Reference Manual, IPCC Guidelines for National Greenhouse Gas Inventories, Vol. 3 (Paris, France, 1995), pp. 1.24-1.29. and natural gas) is assumed to be 99.5 percent complete. ${ }^{113}$ Conceptually, fuel may be "lost" before combustion due to evaporation, leaks, or spills; it may be subject to incomplete combustion and vented to the atmosphere in the form of volatile organic compounds or particulates; or it may remain at the site of combustion in the form of carbon-containing ash or soot.

\section{Data Sources}

Fossil Fuel Consumption: (1980-1993): Energy Information Administration, State Energy Data Report: Consumption Estimates, DOE/ELA-0214(93) (Washington, DC, July 1995). (1994 and 1995): Energy Information Administration, Monthly Energy Review, DOE/EIA-0035(96/07) (Washington, DC, July 1996), and Petroleum Supply Annual 1995, DOE/EIA-0340(95)/1 (Washington, DC, May 1996). Energy Information Administration, Natural Gas Annual 1994, DOE/EIA-0131(94) (Washington, DC, October 1995).

Non-Fuel Use of Energy and Biofuels Consumption (1980-1995): Energy Information Administration, Annual Energy Review 1995, DOE/EIA-384(95) (Washington, DC, July 1996), and Petroleum Supply Annual 1995, DOE/EIA-0340(95)/1 (Washington, DC, May 1996).

See also http://www.eia.doe.gov.

\section{Adjustments to U.S. Energy Consumption}

In recent years, there have been several estimates of U.S. carbon emissions, some of which differ by as much as 5 percent. Two significant reasons for the differences in emissions estimates (beyond those associated with differences in coefficients) are the definitions of "energy consumption" and "the United States" employed by researchers. Subtle differences in definition can produce variations of several percentage points in reported energy consumption, and hence in carbon emissions. Some estimates include U.S. territories while others exclude them. If consumption is estimated as "apparent consumption" based on production plus imports minus exports plus stock change, then statistical discrepancies will be included in consumption. International bunkers are sometimes counted as domestic consumption, and sometimes as exports. This section describes how each of these adjustments is accommodated in the EIA estimates.

\footnotetext{
${ }^{113}$ Intergovernmental Panel on Climate Change, Greenhouse Gas Inventory Reference Manual, IPCC Guidelines for National Greenhouse Gas Inventories, Vol. 3 (Paris, France, 1995), p. 1.33.
} 


\section{U.S. Territories}

\section{Emissions Sources}

EIA's energy data for the United States cover only the 50 States and the District of Columbia. In contrast, energy data produced by the International Energy Agency for the United States cover the 50 States plus U.S. territories, including Puerto Rico, the U.S. Virgin Islands, and Guam, American Samoa, Micronesia, and Wake Island. Annual energy consumption in the U.S. territories is only about 0.5 quadrillion Btu (Table A3). Because all the U.S. territories are islands, their consumption consists primarily of petroleum products. For the territories as a group, oil consumption ranges between 200,000 and 250,000 barrels per day, and coal consumption averages about 300,000 short tons per year, mostly in Puerto Rico.

\section{Estimation Method}

Energy consumption for U.S. territories was converted to carbon emissions using the same emissions coefficients applied to U.S. energy data. Carbon emissions for U.S. territories ranged from 10 to 12 million metric tons per year (see Table 15 in Chapter 2). Because a large portion of reported energy consumption in U.S. territories was from "other petroleum," there is a degree of uncertainty about the correct emissions factor to be used in this area, as well as the reliability of underlying data.

\section{Data Sources}

1980-1992: Energy Information Administration, International Energy Annual, DOE/EIA-0219 (Washington, DC, various years), and unpublished estimates for Wake Island, American Samoa, and the Pacific Trust Territories, which are included as "Other" in the Far East and Oceania region in the International Energy Annual. 1993-1995: EIA estimate.

\section{International Bunker Fuels}

\section{Emissions Sources}

The term "international bunker fuels" refers to fuel purchased by merchant ships in U.S. ports and by international air carriers in U.S airports. By convention, trade statistics treat sales of bunker fuels as exports by the selling country, because the purchaser promptly hauls the fuel outside national boundaries. This convention is followed by organizations that prepare international energy statistics, such as the United Nations and the International Energy Agency.

Bunker fuels, however, are an export without a corresponding import, because the purchasing ship generally burns the fuel on the high seas. EIA energy statistics, which are based on domestic sales of products, treat bunker fuels sales in the same way as sales of other fuels, i.e., as domestic energy consumption. Carbon emissions from bunker fuels are,

Table A3. Energy Consumption in U.S. Territories and International Bunkers, 1988-1995 (Quadrillion Btu)

\begin{tabular}{|c|c|c|c|c|c|c|c|c|}
\hline Place & 1988 & 1989 & 1990 & 1991 & 1992 & 1993 & P1994 & P1995 \\
\hline \multicolumn{9}{|l|}{ U.S. Territories } \\
\hline Puerto Rico & 0.30 & 0.30 & 0.29 & 0.37 & 0.32 & 0.33 & 0.42 & 0.27 \\
\hline Virgin Islands & 0.08 & 0.12 & 0.11 & 0.12 & 0.11 & 0.12 & 0.11 & 0.18 \\
\hline American Samoa & 0.01 & 0.01 & 0.01 & 0.01 & 0.01 & 0.01 & 0.01 & 0.01 \\
\hline Guam & 0.01 & 0.01 & 0.03 & 0.03 & 0.03 & 0.05 & 0.06 & 0.05 \\
\hline Micronesia & * & * & * & * & * & * & * & * \\
\hline Wake Island & 0.02 & 0.02 & 0.02 & 0.02 & 0.02 & 0.02 & 0.02 & 0.02 \\
\hline Total ....... & 0.42 & 0.46 & 0.46 & 0.54 & 0.49 & 0.53 & 0.62 . & 0.53 \\
\hline U.S. Bunker Fuels . . . . . . . . . . . . . & 1.00 & 1.06 & 1.05 & 1.11 & 1.17 & 1.06 & 1.02 & NA \\
\hline
\end{tabular}

"Less than 5 trillion Btu.

$P=$ preliminary data. $N A=$ not available.

Notes: Energy consumption in Micronesia ranged from 0.002 to 0.004 quadrillion Btu. Data in this table are revised from the data contained in the previous EIA report, Emissions of Greenhouse Gases in the United States 1987-1994, DOE/EIA-0573(87-94) (Washington, DC, October 1995).

Sources: U.S. Territories: Energy Information Administration, International Energy Annual, DOE/EIA-0219 (various years), and unpublished data included in "Other" countries in the Asia/Pacific region. Data are shown in tables of "Apparent Consumption of Petroleum Products." Data for 1992 and 1993 based on unpublished preliminary information. Bunker Fuels: Jet Fuel—Oak Ridge National Laboratory, Transportation Energy Data Book (Oak Ridge, TN, various years); Distillate and Residual Fuel Oils, 19871990-Energy Information Administration, International Energy Annual, DOE/EIA-0219 (Washington, DC, 1987-1990); Distillate and Residual Fuel Oils, 1991-1994-Energy Information Administration, Fuel Oil and Kerosene Sales, DOE/EIA-0535 (Washington, DC, 1991-1994). 
therefore, already counted in the domestic energy consumption of the United States-primarily as transportation-related consumption of residual oil. Those who wish to understand the differences between emissions inventories based on international energy statistics and EIA data will, however, need to know the amount of energy consumption and the amount of carbon emissions associated with international bunkers. Table A3, therefore, shows U.S. international bunker fuel usage. ${ }^{114}$ The amount is about 1.1 quadrillion Btu (or 500,000 barrels per day), largely of residual oil. It accounts for emissions of about 19 to 24 million metric tons of carbon annually (see Table 15 in Chapter 2).

\section{Estimation Method}

The appropriate carbon coefficient was applied to estimated annual consumption for several fuels (including residual and distillate fuels, as well as kerosene-type jet fuels) with the assumption that 99 percent of the fuel is combusted.

\section{Data Sources}

Distillate and Residual Fuels: (1980-1990): Energy Information Administration, International Energy Annual, DOE/EIA-0219 (Washington, DC, 1980-1990). (19911994): Energy Information Administration, Fuel Oil and Kerosene Sales, DOE/EIA-0535 (Washington, DC, 19911994). Jet Fuels (1980-1994): Oak Ridge National Laboratory, Transportation Energy Data Book (Oak Ridge, TN, various years).

\section{Unmetered Natural Gas Consumption}

\section{Emissions Source}

The "balancing item" in natural gas statistics produced by EIA represents the difference between reported supply and disposition of the gas. On an annual basis, the volume of natural gas distributed by suppliers has always been larger than that reportedly consumed. This discrepancy can be attributed to the effects of measurement errors, data reporting problems, pipeline leakage, and unreported consumption or stock changes.

Repairing leaks has become a priority in pipeline operations, due to safety and liability concerns. For this reason, only 1 percent of natural gas marketed can be attributed to pipeline leakage. Leaked gas enters the atmosphere in the form of methane. (Estimates of methane emissions from natural gas leakage can be found in Chapter 3 of this report.) While measurement errors and data reporting problems certainly exist in the natural gas industry, these errors ought not to be "tilted" in the direction of gas supply unless there is unreported consumption. The EIA believes that the amount of gas in the "balancing item". less the amount lost to leakage is more likely than not to reflect unreported consumption.

\section{Estimation Method}

Emissions from this source were estimated by first converting the volume of unmetered consumption into Btu, then multiplying by a carbon emissions coefficient. Annually, emissions from unreported natural gas consumption tend to fall in the range of 1 to 4 million metric tons (Table A4).

\section{Data Sources}

Gas Consumption and Balancing Item: (1980-1994): Energy Information Administration, Natural Gas Annual, DOE/ELA-0131 (Washington, DC, various years). (1995): Energy Information Administration, Natural Gas Monthly, DOE/ELA-0130(96/05) (Washington, DC, May 1996). Estimated Gas Leakage: Estimates presented in Chapter 3 and based on methodology for methane emissions in the oil and gas production industry, found later in this appendix.

\section{Industrial Sources}

Carbon dioxide emissions from "industrial sources" are industrial emissions that are not caused by the combustion or feedstock use of commercial fossil fuels. These emissions are typically created either by the combustion of waste products containing fossil carbon (natural gas flaring) or by chemical reactions with carbon-containing minerals (for example, calcining sodium carbonate [limestone] to make lime or cement).

\section{Energy Production}

\section{Emissions Sources}

U.S. energy production also generates small volumes of carbon dioxide emissions. The two principal sources of these emissions are flaring of natural gas and venting

\footnotetext{
${ }^{114} \mathrm{Up}$ to 1990, bunker fuel consumption was reported by the U.S. Department of Commerce, based on trade data. Since 1991, bunker fuel data have been collected by the EIA, based on sales of specialized marine fuels by wholesalers. These data do not distinguish between international and domestic bunker fuel, nor do they provide for aviation bunkers. For recent years, international aviation bunkers and international marine bunkers were estimated on the basis of computations made by Oak Ridge National Laboratory in its Transportation Energy Data Book, Edition 13, p. A-5. International bunkers were assumed to account for 25 percent of marine distillate sales, 75 percent of marine fuel oil sales, and 15 percent of kerosene-based jet fuel sales.
} 
Table A4. U.S. Natural Gas Consumption and Balancing Item, 1988-1995

\begin{tabular}{|c|c|c|c|c|c|c|c|c|}
\hline Item & 1988 & 1989 & 1990 & 1991 & 1992 & 1993 & 1994 & P1995 \\
\hline Gas Consumption (Trillion Cubic Feet) ....... & 18.03 & 18.80 & 18.72 & 19.04 & 19.54 & 20.28 & 20.76 & 21.60 \\
\hline "Balancing Item" (Trillion Cubic Feet) & -0.45 & -0.22 & -0.15 & -0.50 & -0.51 & -0.11 & -0.30 & -0.26 \\
\hline Estimated Gas Leakage (Trillion Cubic Feet) & -0.18 & -0.18 & -0.19 & -0.19 & -0.19 & -0.19 & -0.19 & -0.19 \\
\hline Unmetered Consumption (Trillion Cubic Feet) . . & -0.27 & -0.03 & 0.03 & -0.31 & -0.32 & 0.08 & -0.11 & -0.07 \\
\hline $\begin{array}{l}\text { Estimated Unmetered Carbon Emissions } \\
\text { (Million Metric Tons) } \ldots \ldots \ldots \ldots \ldots \ldots \ldots\end{array}$ & 3.67 & 0.42 & -0.41 & 4.36 & 4.34 & -1.10 & 1.44 & 0.91 \\
\hline
\end{tabular}

$P=$ preliminary data.

Note: Data in this table are revised from the data contained in the previous EIA report, Emissions of Greenhouse Gases in the United States 1987-1994, DOE/EIA-0573(87-94) (Washington, DC, October 1995).

Sources: Energy Information Administration, Natural Gas Annual, DOE/EIA-0131 (Washington, DC, 1987-1994), and Natural Gas Monthly, DOE/EIA-0130(96/05) (Washington, DC, May 1996), p. 3. Leakage estimates from this report (see Chapter 3). All gas in the balancing item not attributed to leakage is assumed as unreported consumption.

of the carbon dioxide that is produced in conjunction with natural gas. ${ }^{115}$ When a field is developed for petroleum extraction, any natural gas associated with that field may be flared if its use is not economically justifiable. This is typically the case with a remote site or when the gas is of poor quality or minimal volume. During natural gas production, flaring may be used for disposal of waste products (e.g., hydrogen sulfide), capacity testing, or as a result of process upsets.

\section{Estimation Method}

The method for estimating emissions from natural gas flaring is based on the volume of vented and flared gas reported to the EIA by each State. This composite volume is scaled by a State-specific flaring percentage to ascertain the amount of natural gas flared in that State. The percent flared value is taken from a 1990 Department of Energy study that determined the relative split between venting and flaring for each State. ${ }^{116}$ To calculate carbon emissions, the State figures are aggregated, converted into Btu, and then multiplied by the emissions coefficient equal to 14.92 million metric tons of carbon per quadrillion Btu.

As estimates presented in Chapter 2 indicate, natural gas flaring is a minor source of emissions, accounting for only about 1.5 to 2.0 million metric tons of carbon annually. There is some uncertainty associated with these estimates, given that operators in the field are not required to meter the amount of gas that is vented or flared. Further, methods used by States to determine vented and flared gas statistics are not uniform.

\section{Data Sources}

Venting and Flaring: (1980-1994): Energy Information Administration, Natural Gas Annual, DOE/EIA-0131 (Washington, DC, various years). (1995): Natural Gas Monthly, DOE/EIA-0130(95/06) (Washington, DC, May 1996).

\section{Industrial Processes}

In addition to energy-related emissions, carbon dioxide is also produced during certain industrial processes. The primary source of industrial emissions is limestone $\left(\mathrm{CaCO}_{3}\right)$ calcination to create lime $(\mathrm{CaO})$. These two compounds are basic materials in a variety of manufacturing processes, particularly cement, iron and steel, and glass. Other sources of industrial emissions include the production and use of soda ash $\left(\mathrm{Na}_{2} \mathrm{CO}_{3}\right)$, the manufacture of carbon dioxide, and aluminum production.

For this source category, emissions estimates are based on the compound used in the industrial process. Table A5 presents activity data for industrial processes. By multiplying the amount of production or consumption of the compound by a carbon coefficient (the relative amount of carbon in that compound), a process-specific estimate is derived. In recent years, industrial sources have accounted for about 17 to 18 million metric tons of carbon annually. Each industrial process, emissions source, and estimation method is discussed below.

\footnotetext{
${ }^{115}$ See discussion of carbon dioxide manufacture for the treatment of vented carbon dioxide.

${ }^{116}$ U.S. Department of Energy, An Evaluation of the Relationship Between the Production and Use of Energy and Atmospheric Methane Emissions, DOE/NBB-0088P (Washington, DC, April 1990). See Appendix C.
} 
Table A5. Production Data for Industrial Sources of Carbon Dioxide, 1984-1995

(Thousand Metric Tons)

\begin{tabular}{|c|c|c|c|c|c|c|c|c|c|c|c|c|}
\hline Item & 1984 & 1985 & 1986 & 1987 & 1988 & 1989 & 1990 & 1991 & 1992 & 1993 & 1994 & P1995 \\
\hline Cement Clinker . . . . . . . & 62,467 & 60,140 & 62,252 & 62,328 & 62,727 & 62,847 & 63,313 & 61,595 & 62,171 & 65,745 & 69,787 & 75,939 \\
\hline Masonry Cement ....... & 2,980 & 2,955 & 3,237 & 3,302 & 3,261 & 2,988 & 2,911 & 2,591 & 2,805 & 2,962 & 3,613 & 3,185 \\
\hline Lime Produced & 14,441 & 14,231 & 13,128 & 14,270 & 15,466 & 15,557 & 15,832 & 15,667 & 16,199 & 16,932 & 17,300 & 18,500 \\
\hline Limestone in Iron Smelting . & 6,048 & 6,857 & 5,468 & 4,080 & 4,177 & 4,275 & 3,955 & 3,634 & 3,098 & 2,561 & 4,359 & 4,359 \\
\hline Limestone in Steelmaking . . & 834 & 689 & 734 & 796 & 866 & 1,058 & 682 & 738 & 612 & 1,087 & 1,224 & 1,241 \\
\hline Limestone in Glass . . . . . . . & 780 & 366 & 526 & 685 & 463 & 241 & 255. & 269 & 354 & 439 & 593 & 593 \\
\hline Limestone in FGD . . . . . . . & 2,540 & 2,586 & 3,017 & 3,923 & 3,783 & 4,386 & 4,368 & 4,605 & 4,479 & 4,273 & 4,623 & 5,814 \\
\hline Dolomite . . . . . . . . . . & 2,307 & 2,464 & 1,793 & 1,122 & 882 & 641 & 687 & 732 & 640 & 549 & 601 & 601 \\
\hline Soda Ash Production ..... & 5,899 & 5,959 & 6,671 & 6,990 & 7,618 & 8,208 & 8,147 & 8,152 & 8,269 & 8,051 & 8,111 & 9,167 \\
\hline Soda Ash in Glass . . . . . . & 3,085 & 3,084 & 3,152 & 3,343 & 3,390 & 3,294 & 3,177 & 2,997 & 3,082 & 3,095 & 3,150 & 3,130 \\
\hline Soda Ash in FGD ....... & 154 & 157 & 168 & 206 & 211 & 222 & 179 & 155 & 156 & 146 & 173 & 211 \\
\hline Sodium Silicate . . . . . . . & 621 & 628 & 717 & 863 & 736 & 792 & 740 & 789 & 838 & 912 & 1,008 & 1,021 \\
\hline Sodium Tripolyphosphate .. & 628 & 555 & 560 & 532 & 498 & 526 & 451 & 419 & 399 & 426 & 423 & 423 \\
\hline Aluminum Manufacture .... & 4,099 & 3,500 & 3,037 & 3,343 & 3,944 & 4,030 & 4,048 & 4,121 & 4,042 & 3,695 & 3,299 & 3,350 \\
\hline
\end{tabular}

$P=$ preliminary data.

Sources: U.S. Department of the Interior, Bureau of Mines, Mineral Commodity Summaries (Washington, DC, various years). U.S. Department of the Interior, Bureau of Mines, Cement Annual Report (Washington, DC, various years). American Iron and Steel Institute, Annual Statistical Report (Washington, DC, various years). U.S. Department of the Interior, Bureau of Mines, Soda Ash Annual Report (Washington, DC, various years) (soda ash production calculated from quantity of trona ore production). U.S. Department of the Interior, Bureau of Mines, Crushed Stone Annual Report (Washington, DC, various years). Chemical Manufacturers Association, U.S. Chemical Industry Statistical Handbook 1993(Washington, DC, September 1993). Energy Information Administration unpublished survey data, Steam Electric Plant Operation and Design Report, Form EIA-767 (Washington, DC, various years). Freedonia Group, Inc., Carbon Dioxide, Business Research Report B286 (Cleveland, $\mathrm{OH}$, November 1991), and Carbon Dioxide, Industry Study 564 (Cleveland, OH, February 1994).

\section{Cement Manufacture}

More than half of the carbon dioxide emissions from industrial sources originate from cement manufacturing (see Chapter 2).

Emissions Sources. Four basic materials are required to make cement: calcium, silicon, aluminum, and iron. Substrates of these materials are ground into a powder and heated in a kiln. While in the kiln, limestone (the predominant source of calcium) is broken down into carbon dioxide and lime. The carbon dioxide is driven off into the atmosphere. After the kilning process has been completed, cement clinker is left.

Estimation Method. One mole of calcined limestone produces one mole of carbon dioxide and one mole of lime. Since virtually all of the lime produced is absorbed into the clinker, the lime content of clinker is assumed to be representative of the amount of carbon dioxide that is emitted. In order to estimate emissions from cement manufacture, a carbon coefficient must be calculated. The EIA has adopted the IPCC recommendation that 64.6 percent of cement clinker is lime. ${ }^{117}$ Multiplying this lime content factor by the ratio of carbon produced to lime produced yields the coefficient for cement clinker. A separate coefficient is necessary for estimating emissions from the additional lime used to produce masonry cement. In this case, the amount of lime not accounted for as clinker is assumed to be 3 percent. ${ }^{118}$ This factor is then multiplied by the same production ratio of carbon to lime, generating the carbon coefficient for masonry cement.

\section{Lime Manufacture}

Lime is an important chemical with a variety of industrial, chemical, and environmental applications.

Emissions Sources. Lime production involves three main stages: stone preparation, calcination, and hydration. Carbon dioxide is generated during the calcination stage, when limestone is roasted at high temperatures, just as it is released during clinker production. The carbon dioxide is driven off as a gas and normally exits the system with the stack gas.

Estimation Method. Based on the ratio of the molecular weight of carbon dioxide to the weight of calcium carbonate, the EIA assumes that 785 metric tons of carbon dioxide, or 214 metric tons of carbon, are released for every 1,000 metric tons of lime produced. This factor is applied to annual levels of lime manufacture to estimate potential emissions. The EIA does not account for the relatively minor instances in which the carbon dioxide is recovered or reabsorbed, due to lack of data at the present time.

\footnotetext{
${ }^{117}$ International Panel on Climate Change, Greenhouse Gas Inventory Reference Manual, IPCC Guidelines for National Greenhouse Gas Inventories, Vol. 3 (Paris, France, 1995), p. 2.4.

${ }^{118}$ U.S. Environmental Protection Agency, Inventory of U.S. Greenhouse Gas Emissions and Sinks: 1990-1993 (Washington, DC, 1994$)$, p. 32.
} 


\section{Limestone and Dolomite Consumption}

These are basic raw materials used by a wide variety of industries, including the construction, agriculture, chemical, and metallurgical industries.

Emissions Sources. Limestone (including dolomite) can be used as a flux or purifier in metallurgical furnaces, as a sorbent in flue gas desulfurization (FGD) systems in utility and industrial plants, or as a raw material in glass manufacturing. Limestone is heated during these processes, generating carbon dioxide as a byproduct.

Estimation Method. Assuming that limestone has a carbon content of 12 percent and dolomite 13.2 percent, the EIA applies the appropriate factor to the annual level of consumption in the iron smelting, steelmaking, and glass manufacture industries, and in flue gas desulfurization systems that use this sorbent. This amounts to 120 metric tons of carbon for every 1,000 metric tons of limestone consumed, or 132 metric tons of carbon for every 1,000 tons of dolomite consumed (when dolomite is distinguished in the data).

\section{Soda Ash Manufacture and Consumption}

Commercial soda ash (sodium carbonate) is used in many familiar consumer products, such as glass, soap and detergents, paper, textiles, and food.

Emissions Sources. Two methods are used to manufacture natural soda ash in the United States. The majority of production comes from Wyoming, where soda ash is manufactured by calcination of trona ore in the form of naturally occurring sodium sesquicarbonate. For every mole of soda ash created in this reaction, one mole of carbon dioxide is also produced and vented to the atmosphere. The other process used to manufacture soda ash is carbonation of brines; however, the carbon dioxide driven off in this process is captured and reused.

Once manufactured, most soda ash is consumed in glass and chemical production. Other uses include water treatment, flue gas desulfurization, soap and detergent production, pulp and paper production, etc. As soda ash is processed for these purposes, additional carbon dioxide may be emitted if the carbon is oxidized. Because of the limited availability of specific information about such emissions, only certain uses of soda ash are considered in this report. Sodium silicate and sodium tripolyphosphate are included in this category as chemicals manufactured from soda ash and components of detergents.
Estimation Method. For soda ash manufacture, in order to ensure that carbon dioxide from the carbonation of brines is not included in emissions estimates, the calculations in this report are derived solely from trona ore production figures. Approximately 1.8 metric tons of trona ore are required to yield 1 metric ton of soda ash. This amounts to 97 million metric tons of carbon for every 1,000 tons of trona ore produced annually. For soda ash consumption, the EIA applies a factor of 113 metric tons for every 1,000 metric tons of soda ash consumed in glass manufacturing or in flue gas desulfurization.

\section{Carbon Dioxide Manufacture}

Emissions Source. Carbon dioxide is produced from a small number of natural wells and as a byproduct of chemical (i.e., ammonia) manufacturing. The Freedonia Group has determined that the United States exhibits an 80 to 20 percent split between carbon dioxide produced as a byproduct and carbon dioxide produced from wells. ${ }^{119}$ Emissions of byproduct carbon dioxide are incorporated into the natural gas energy consumption estimates as nonfuel, nonsequestered carbon and therefore are not included here to avoid doublecounting.

Most carbon dioxide produced from wells is injected back into the ground for enhanced oil recovery. This process sequesters the carbon dioxide, at least in the short run. Conceptually, only carbon dioxide produced from wells and diverted to industrial use is emitted to the atmosphere.

Estimation Method. The Freedonia Group estimates that nonsequestering industrial use of carbon dioxide resulted in emissions of 1.3 million metric tons of carbon in $1993 .{ }^{120}$ If 20 percent of this industrial use is supplied by wells, emissions can be estimated at 0.26 million metric tons of carbon. Based on the Freedonia report, the 1994 estimate is calculated assuming an annual 4.2 percent increase, implying emissions of 0.29 million metric tons of carbon.

\section{Aluminum Manufacture}

Aluminum is an element used in alloys. Because it is light in weight, malleable, and not readily corroded or tarnished, it is used as a principal material for kitchen utensils, aircraft, some automobiles, bicycles, and other manufactured products. The United States is a major producer of aluminum and also an importer, depending on market conditions.

\footnotetext{
${ }^{119}$ The Freedonia Group, Inc., Carbon Dioxide, Business Research Report B286 (Cleveland, OH, November 1991), p. 46.

${ }^{120}$ The Freedonia Group, Inc., Carbon Dioxide, Industry Study 564 (Cleveland, OH, February 1994), p. 37.
} 
Emissions Sources. Carbon dioxide is emitted during the aluminum production process when alumina (aluminum oxide) is reduced to aluminum. The aluminum oxide $\left(\mathrm{Al}_{2} \mathrm{O}_{3}\right)$ is exposed to an anode of carbon, forming aluminum (Al) and carbon dioxide.

Estimation Method. Research indicates that 1.5 to 2.2 metric tons of carbon dioxide are emitted per metric ton of aluminum produced. ${ }^{121}$ The EIA uses the midpoint of this range for estimating emissions.

\section{Data Sources for Industrial Processes}

Cement and Clinker Production: (1980-1994): U.S. Department of the Interior, Bureau of Mines, Cement Annual Report (Washington, DC, various years). (1995): U.S. Department of the Interior, U.S. Geological Service, Office of Minerals, Faxback Service.

Lime Manufacture: (1980-1994): U.S. Department of the Interior, Bureau of Mines, Mineral Commodity Summaries (Washington, DC, various years). (1995): U.S. Department of the Interior, U.S. Geological Service, Office of Minerals, Faxback Service.

Limestone Consumption: Iron Smelting, Steelmaking, and Glass Manufacture: (1980-1994): U.S. Department of the Interior, Bureau of Mines, Crushed Stone Report (Washington, DC, various years). (1995): ELA estimate. Flue Gas Desulfurization (1980-1995): Energy Information Administration, unpublished survey data, Form EIA-767, "Steam Electric Plant Operation and Design Report" (Washington, DC, various years).

Soda Ash: Manufacture and Consumption in Glass Making: (1980-1994): U.S. Department of the Interior, Bureau of Mines, Soda Ash Report (Washington, DC, various years). (1995): U.S. Department of the Interior, U.S. Geological Service, Office of Minerals, Faxback Service. Flue Gas Desulfurization (1980-1995): Energy Information Administration, unpublished survey data, Form EIA-767, "Steam Electric Plant Operation and Design Report" (Washington, DC, various years). Sodium Silicate and Sodium Tripolyphosphate: (19801994): Chemical Manufacturers Association, U.S. Chemical Industry Statistical Handbook 1994 (Washington, DC, September 1995). (1995): Chemical and Engineering News, "Growth of Top 50 Chemicals Slowed in 1995 from Very High 1994 Rate" (April 1996).

Carbon Dioxide: Freedonia Group, Inc., Carbon Dioxide, Business Research Report B286 (Cleveland, OH, November 1991), and Carbon Dioxide, Industry Study 564 (Cleveland, OH, February 1994).
Aluminum: (1980-1994): U.S. Department of the Interior, Bureau of Mines, Aluminum Report (Washington, DC, various years). (1995): U.S. Department of the Interior, U.S. Geological Service, Office of Minerals, Faxback Service.

\section{Methane}

\section{Energy Sources}

\section{Oil and Gas Production, Processing, and Distribution}

\section{Emissions Sources}

Natural gas may be released from the oil and gas system at several points, including oil wells, oil refineries, natural gas wellheads, gas processing plants, and gas transmission and distribution pipelines. Because methane is the principal constituent of natural gas (representing about 95 percent of the mixture) releases of natural gas lead to methane emissions.

Oil and Gas Production and Processing. As natural gas extracted at the wellhead is transferred to processing plants through gathering pipelines, leakage from valves, meters, and flanges occurs. Pneumatic valves, pressurized with natural gas, will emit gas when reset. Natural gas also escapes when gathering pipelines are emptied for maintenance. After the gas reaches the processing plant, additional emissions occur as a result of leakage, maintenance operations, and system upsets. System upsets result from sudden increases in pressure that require the release of gas as a safety measure or, failing that, result in a system rupture. Such events are uncommon in the U.S. oil and gas system and contribute only a minor amount to overall emissions.

Gas Transmission and Distribution. High-pressure transmission pipelines are used to transport natural gas from production fields and gas processing facilities to distribution pipelines. Gas pressure is lowered at gate stations before it enters the local distribution system. Natural gas may escape through leaky pipes and valves. It also may be released-as part of compressor exhaust, while resetting pneumatic devices, and during routine maintenance.

Oil Refining and Transportation. Methane leaks from equipment when methane and oil are separated during the refining process. When oil is transferred to storage tanks at the refinery methane is emitted via vapor

${ }^{121}$ D. Abrahamson, "Aluminum and Global Warming," Nature, Vol. 356 (April 1992), p. 484. 
displacement. Methane not destroyed during flaring operations will also be vented to the atmosphere. Vapor displacement emissions also occur during loading and unloading of oil barges and tankers.

Gas Venting. When an oil reservoir is developed for extraction there will often be associated natural gas produced at the wellhead. If the flow of associated gas is too small or intermittent to be of value the gas will be vented or flared. Associated gas with an insufficient heat content to marketed may also be vented or flared. If a site lacks the necessary gathering and processing facilities for associated gas, that gas may be vented or flared. When gas is flared, its methane content is converted to carbon dioxide (see emissions estimates in Chapter 2 and methods above), but when it is vented methane is released directly to the atmosphere.

\section{Estimation Methods}

Oil and Gas Production and Processing. Estimates of emissions from oil and gas wells are scaled to the number of wells in operation, emissions from gathering pipelines are pegged to pipeline miles, and emissions from gas processing plants vary with gas throughput. Activity data for the oil and gas system are shown in Table A6. Estimates of methane emissions from these sources are scaled to point-in-time estimates appearing in a study prepared jointly by the U.S. Environmental Protection Agency and the Gas Research Institute (EPA/GRI). ${ }^{122}$ With a more representative sample, and more recent data, the EPA/GRI study improved substantially on previous estimates of emissions from the natural gas system. This report uses emissions factors developed on the basis of that study, replacing factors developed from earlier studies. A comparison of the new emissions factors and those used previously appears in Table A7.

Gas Transmission and Distribution. Methane emissions from transmission and distribution pipeline and gate stations were also estimated using emissions factors from the joint EPA/GRI study. These emissions estimates were scaled to pipeline mileage, with separate emissions factors for plastic and non-plastic pipeline (Table A7).

Table A6. Activity Data for Methane Emissions from Oil and Gas Production, Processing, and Distribution, 1984-1995

\begin{tabular}{|c|c|c|c|c|c|c|c|c|c|c|c|c|c|}
\hline Item & Units $^{\mathbf{a}}$ & 1984 & 1985 & 1986 & 1987 & 1988 & 1989 & 1990 & 1991 & 1992 & 1993 & 1994 & 1995 \\
\hline Natural Gas Wellheads . . . . . . . & Thousand Wells & 234 & 242 & 242 & 249 & 257 & 263 & 270 & 277 & 276 & 284 & 288 & 294 \\
\hline Producing Oll Wells . . . . . . . . . . & Thousand Wells & 621 & 647 & 629 & 620 & 627 & 607 & 602 & 610 & 594 & 584 & 582 & 575 \\
\hline Gathering Pipelines $\ldots \ldots \ldots \ldots$ & Thousand Wells & 94 & 94 & 94 & 94 & 92 & 91 & 90 & 86 & 86 & 77 & 77 & 77 \\
\hline Total Gas Throughput . . . . . . . & Tcf & 14 & 13 & 13 & 13 & 13 & 13 & 15 & 16 & 16 & 16 & 16 & 16 \\
\hline Total Gas Withdrawais $\ldots . \ldots \ldots$ & Tcl & 20 & 20 & 19 & 20 & 21 & 21 & 22 & 22 & 22 & 23 & 24 & 24 \\
\hline $\begin{array}{l}\text { Transmission System Pipelines ... } \\
\text { Distrlbution Pipellne }\end{array}$ & Thousand Miles & 272 & 271 & 271 & 274 & 275 & 276 & 280 & 282 & 285 & 270 & 276 & 276 \\
\hline Main Pipeline . . . . . . . . . . & Thousand Miles & 737 & 753 & 769 & 784 & 800 & 818 & 837 & 858 & 883 & 914 & 965 & 965 \\
\hline Plastic $\ldots \ldots \ldots \ldots \ldots \ldots$ & Thousand Miles & 114 & 126 & 138 & 152 & 166 & 183 & 202 & 222 & 244 & 269 & 284 & 284 \\
\hline Nonplastlc $\ldots \ldots \ldots \ldots \ldots$ & Thousand Miles & 623 & 628 & 631 & 632 & 634 & 635 & 635 & 636 & 639 & 646 & 635 & 635 \\
\hline Service Pipeline . . . . . . . . . & Thousand Miles & 436 & 389 & 400 & 411 & 449 & 461 & 474 & 494 & 494 & 515 & 515 & NA \\
\hline Plastic $\ldots \ldots \ldots \ldots \ldots \ldots$ & Thousand Miles & 0 & 140 & 151 & 163 & 201 & 212 & 226 & 246 & 246 & 267 & 267 & NA \\
\hline Nonplastic . . . . . . . . . . . & Thousand Miles & 248 & 248 & 248 & 248 & 248 & 248 & 248 & 248 & 248 & 248 & 248 & NA \\
\hline $\begin{array}{l}\text { Total Distrlbution Pipeline ...... } \\
\text { Marine Transport }\end{array}$ & Thousand Miles & 436 & 389 & 400 & 411 & 449 & 461 & 474 & 494 & 494 & 515 & 515 & NA \\
\hline Net Crude Imports $\ldots \ldots \ldots \ldots$. & Kbd & 3,426 & 3,201 & 4,178 & 4,674 & 5,107 & 5,843 & 5,894 & 5,782 & 6,083 & 6,787 & 7,063 & 7,230 \\
\hline Net Crude Exports $\ldots \ldots \ldots \ldots$. & Kbd & 181 & 204 & 154 & 151 & 155 & 142 & 109 & 116 & 89 & 98 & 99 & 95 \\
\hline Alaskan Crude Production . . . . . . & Kbd & 1,722 & 1,825 & 1,867 & 1,962 & 2,017 & 1,874 & 1,773 & 1,798 & 1,714 & 1,582 & 1,559 & 1,484 \\
\hline Total Marine Transpoit . . . . . . . . & Kbd & 5,329 & 5,230 & 6,199 & 6,787 & 7,279 & 7,859 & 7,776 & 7,696 & 7,886 & 8,467 & 8,721 & 8,809 \\
\hline Refinery Crude Input . . . . . . . . . & Mbd & 12 & 12 & 13 & 13 & 13 & 13 & 13 & 13 & 13 & 14 & 14 & 14 \\
\hline
\end{tabular}

aUnits: $T c f=$ trillion cubic teet; Kbd = thousand barrels per day; Mbd = million barrels per day

$\mathrm{NA}=$ not available.

Sources; Natural Gas Wellheads, Total Gas Throughput, and Total Gas Withdrawals-Energy Information Administration, Natural Gas Annual, DOE/EIA-0131 (various years). Produclng Oil Wells-World Oil, February issue (various years). Gathering Pipelines, Transmission Pipelines, and Distribution Pipelines-American Gas Assoclation, Gas Facts (various years). Net Crude Imports, Net Crude Exports, Refinery Crude Input, and Alaskan Crude Production-Energy Information Administration, Petroleum Supply Annual, DOE/EIA-0340 (various years).

${ }^{122}$ M.R. Harrison and R.M. Cowgill, Tier 2 Summary of Methane Emissions from the Natural Gas Industry, Draft Final Report, Prepared for the Gas Research Institute and the U.S. Environmental Protection Agency January 1996). 
Table A7. Methane Emissions Factors for Oil and Gas Production, Processing, and Distribution

\begin{tabular}{|c|c|c|c|}
\hline \multirow[b]{2}{*}{ Emissions Source } & \multicolumn{2}{|c|}{ Emissions Coefficient } & \multirow[b]{2}{*}{ Unit } \\
\hline & EIA 1995 & EIA 1996 & \\
\hline \multicolumn{4}{|l|}{ Oil and Gas Production } \\
\hline Natural Gas Wellheads $\ldots \ldots \ldots \ldots \ldots \ldots$ & $0.870^{\mathrm{a}}$ & $1.070^{\circ}$ & Metric tons per well \\
\hline Oil Wells $\ldots \ldots \ldots \ldots \ldots \ldots \ldots \ldots \ldots$ & $0.072^{\mathrm{a}}$ & $0.072^{d}$ & Metric tons per well \\
\hline Gathering Pipelines $\ldots \ldots \ldots \ldots \ldots$ & $3.590^{\mathrm{a}}$ & $11.935^{d}$ & Metric tons per mile \\
\hline Gas Processing Plants .... & $6.160^{a}$ & $42.678^{d}$ & Metric tons per billion cubic feet of throughput \\
\hline Heaters, Separators, Dehydrators..$\ldots \ldots \ldots$ & $21.870^{\mathrm{a}}$ & $7.884^{d}$ & Metric tons per billion cubic feet of gross withdrawals \\
\hline Transmission Pipeline $\ldots \ldots \ldots \ldots \ldots \ldots \ldots$ & $3.713^{\mathrm{a}}$ & $7.613^{\mathrm{d}}$ & Metric tons per mile \\
\hline Plastic Distribution Pipeline .............. & $0.020^{\mathrm{b}}$ & $0.199^{d}$ & Metric tons per mile \\
\hline Nonplastic Distribution Pipeline ............ & $0.180^{b}$ & $0.790^{d}$ & Metric tons per mile \\
\hline Gate Stations $\ldots \ldots \ldots \ldots \ldots \ldots \ldots$ & $0.092^{\mathrm{a}}$ & $0.461^{d}$ & Metric tons per mile of distribution pipeline \\
\hline System Upsets . . . . . . . . . . . & $0.031^{\mathrm{b}}$ & $0.031^{\mathrm{d}}$ & Metric tons per mile of distribution pipeline \\
\hline \multicolumn{4}{|l|}{ Oil Refineries } \\
\hline Fugitive Emissions & $1.635 \times 10^{-5} \mathrm{c}$ & $1.635 \times 10^{-5} \mathrm{c}$ & Short tons per barrel of refinery capacity \\
\hline Tank Farms $\ldots \ldots \ldots \ldots$ & $4.37 \times 10^{-7} \mathrm{c}$ & $4.37 \times 10^{-7} \mathrm{c}$ & Short tons per barrel of throughput \\
\hline Flaring $\ldots \ldots \ldots \ldots \ldots \ldots \ldots \ldots \ldots$ & $4.00 \times 10^{-7 c}$ & $4.00 \times 10^{-7} \mathrm{c}$ & Short tons per barrel of refinery capacity \\
\hline Crude Transportation (Marine) $\ldots \ldots \ldots \ldots \ldots$. & $2.55 \times 10^{-6} \mathrm{C}$ & $2.55 \times 10^{-5} \mathrm{c}$ & Short tons per barrel loaded \\
\hline
\end{tabular}

aEIA estimate based on scaling of factors published in U.S. Environmental Protection Agency, Anthropogenic Methane Emissions in the United States-Estimates for 1990, Report to Congress (Washington, DC, April 1993).

bu.S. Environmental Protection Agency, Office of Air and Radiation, Anthropogenic Methane Emissions in the United States-Estimates for 1990, Report to Congress (Washington, DC, April 1993).

'Radian Corporation, Global Emissions of Methane from Petroleum Sources, Final Report Prepared for the American Petroleum Institute (Research Triangle Park, NC, February 1992).

'M.R. Harrison and R.M. Cowgill, Tier 2 Summary of Methane Emissions from the Natural Gas Industry, Draft Final Report, Prepared for the Gas Research Institute and the U.S. Environmental Protection Agency (January 1996).

Oil Refining and Transportation. Estimates of emissions from this source were calculated using emissions factors from a 1992 Radian Corporation report ${ }^{123}$ in conjunction with refinery data collected by the Energy Information Administration.

Gas Venting. The EIA collects State-level data on the volume of gas either vented or flared. The portion of venting versus flaring is not collected. However, a 1990 Department of Energy study estimated the share of gas vented and flared in each State. ${ }^{124}$ These shares were applied to annual State venting and flaring data, and the results were aggregated to estimate national emissions.

\section{Data Sources}

Oil and Gas Production and Processing. Natural gas wellheads, gross gas withdrawals, and gas processing plant throughput can be found in EIA's Natural Gas Annual, DOE/EIA-0031 (various years). Number's of operating oil wells are available annually in the February issue of the World Oil journal.

Gas Transmission and Distribution. Transmission and distribution pipeline data are published annually by the American Gas Association in Gas Facts.
Oil Refining and Transportation. Data on volume of crude oil refined and volume of crude oil transported on marine vessels can be found in EIA's Annual Energy Review 1995, DOE/EIA-0384(95) (Washington, DC, July 1996), and Petroleum Supply Annual, DOE/EIA-0340 (Washington, DC, various years).

Gas Venting. State data on gas venting and flaring can be found in EIA's Natural Gas Annual 1995, DOE/EIA0131(95) (Washington, DC, November 1995).

\section{Coal Mining}

\section{Emissions Sources}

As coal is formed from organic material by natural chemical and physical processes, methane is also produced. The methane is stored in the pores (open spaces) of the coal itself and in cracks and fractures within the coalbed. As coal is mined, the pressure surrounding the stored methane decreases, allowing much of it to be released into the operating coal mine (in the case of an underground mine) or into the atmosphere (in the case of a surface mine). The methane remaining in the coal pores is emitted as the coal is transported and pulverized for combustion. There are five avenues for methane emissions from coal mines:

\footnotetext{
${ }^{123}$ Radian Corporation, Global Emissions of Methane from Petroleum Sources, prepared for the American Petroleum Institute (Research Triangle Park, NC, February 1992).

${ }^{124}$ U.S. Department of Energy, An Evaluation of the Relationship Between the Production and Use of Energy and Atmospheric Methane Emissions, DOE/NBB-0088P (Washington, DC, April 1990).
} 
Ventilation Systems in Underground Mines. Methane in concentrations over 5 percent is explosive and presents a mortal danger to coal miners. To meet safety standards set by the Mine Safety and Health Administration (MSHA) requiring levels of methane concentration to be maintained well below the 5 percent threshold, mine operators use large fans to provide a steady airflow across the mine face and ventilate the mine shaft. Typically, these ventilation systems vent substantial quantities of methane as part of fan exhaust.

Degasification Systems in Underground Mines. When the volume of gas in underground mines is too high to be practically reduced to safe levels by standard ventilation techniques, degasification systems are employed. Degasification may take place before mining or may take the form of gob-wells or in-mine horizontal boreholes. Methane captured by degasification systems may be vented, flared, or recovered for energy. As of 1994, some 30 degasification systems were known to be operating in U.S. mines, with 10 mines recovering gas for energy use. ${ }^{25}$

Surface Mines. Because coal mined from the surface has formed at lower temperature and pressure than coal from underground mines, its methane content is lower. Further, because the coal is located near the surface, methane has had ample opportunity to migrate to the atmosphere before mining. Thus, while methane emissions from surface mines are heterogeneous in nature, they are systematically smaller than emissions from underground mines.

Post-Mining Emissions. Methane that remains in coal pores after either underground or surface mining will desorb slowly as the coal is transported (typically by train) to the end user. Because coal that is consumed in large industrial or utility boilers is pulverized before combustion, methane remaining in the coal pores after transport will be released prior to combustion.

Methane Recovery for Energy. In some cases (for example, in some mining degasification systems), methane is emitted from coal mines in sufficiently high volumes and concentrations to permit commercial recovery of the gas as either pipeline gas or fuel for electric power generation. Since coal mine methane recovered commercially is combusted, the quantities recovered are subtracted from estimates of total coal mine methane emissions.

\section{Estimation Method}

Ventilation Systems in Underground Mines. Emissions from this source were segregated into two classes: emissions from "gassy" mines, and emissions from "non-gassy" mines. ${ }^{126}$ Because methane concentrations and airflow in gassy mines are carefully monitored by the Mine Safety and Health Administration (MSHA), a fairly reliable set of data can be derived for emissions from ventilation systems in gassy mines. However, because MSHA data are voluminous and in inconsistent format, it is difficult to compile and available for only a subsample of years: 1980, 1985, 1988,1990 , and 1993. Thus, the available data are used in conjunction with coal production data for those years to develop emissions factors per ton of coal mined on a basin-by-basin level. Emissions factors for non-sample years are interpolated or extrapolated. The resulting emissions factors are then multiplied by production data to estimate emissions from this source (for detailed production data, see Table A8).

Table A8. U.S. Coal Production, 1984-1995

(Million Metric Tons)

\begin{tabular}{|c|c|c|c|c|c|c|c|c|c|c|c|c|}
\hline Mine Type and Basin & 1984 & 1985 & 1986 & 1987 & 1988 & 1989 & 1990 & 1991 & 1992 & 1993 & 1994 & P1995 \\
\hline \multicolumn{13}{|l|}{ Underground } \\
\hline Northern Appalachia ..... & 91.7 & 85.5 & 86.1 & 89.3 & 89.4 & 90.9 & 95.5 & 93.5 & 92.5 & 69.7 & 90.8 & NA \\
\hline Central Appalachla ..... . & 143.6 & 148.4 & 150.8 & 153.9 & 157.9 & 163.7 & 178.6 & 165.3 & 164.1 & 149.1 & 155.0 & NA \\
\hline Warrior Basin . . . . . . . . & 12.0 & 13.1 & 12.0 & 13.0 & 13.5 & 14.8 & 15.9 & 15.5 & 14.5 & 14.1 & 13.1 & NA \\
\hline Illinols Basin . . . . . . . . . & 52.8 & 52.1 & 58.0 & 59.8 & 60.5 & 59.1 & 62.8 & 63.5 & 66.4 & 50.8 & 62.8 & NA \\
\hline Westem ............ & 17.5 & 19.0 & 18.7 & 20.8 & 23.9 & 27.5 & 31.3 & 30.8 & 31.1 & 34.1 & 40.3 & NA \\
\hline Total Underground ..... & 319.4 & 318.2 & 326.9 & 338.2 & 346.7 & 357.2 & 385.0 & 369.3 & 369.3 & 318.4 & 362.0 & NA \\
\hline Surface $\ldots \ldots \ldots \ldots \ldots$. & 493.3 & 483.2 & 480.6 & 495.1 & 515.3 & 532.3 & 548.3 & 534.0 & $\mathbf{5 3 5 . 4}$ & 539.1 & 575.4 & NA \\
\hline Total ................ & 812.6 & 801.4 & 807.5 & 833.4 & 861.9 & 889.5 & 933.4 & 903.4 & 904.7 & 857.5 & 937.4 & NA \\
\hline
\end{tabular}

$P=$ preliminary data. $N A=$ not available.

Sources: Coal production data from Energy Information Administration, Coal Production, DOE/EIA-0118 (Washington, DC, various years), and Coal Industry Annual, DOE/EIA-0584(94) and (95) (Washington, DC, 1994 and 1995).

${ }^{125}$ U.S. Environmental Protection Agency, Office of Air and Radiation, Identifying Opportunities for Methane Recovery at U.S. Coal Mines: Draft Profiles of Selected Gassy Underground Coal Mines (Washington, DC, September 1994).

${ }^{126}$ Gassy mines are defined as those underground coal mines with measured emissions from ventilation exhaust in excess of 100,000 cubic feet of methane per day. 
Emissions from non-gassy mines make up less than 2 percent of all emissions from underground mines. ${ }^{127}$ Basin-level emissions factors for non-gassy mines were established by dividing 2 percent of each basin's estimated emissions from non-gassy mines for 1988 by that year's production levels. The resulting emissions factors are applied to annual production data.

Degasification Systems in Underground Mines. Degasification emissions are not monitored by any regulatory agency. Where degasification does occur, the method of disposition (e.g., venting, flaring, sale for energy) may not be tabulated. Emissions from degasification systems are estimated by multiplying annual production in mines known to have a degasification system in place by a per-ton emissions factor.

Surface Mines. Emissions from U.S. surface mines have not been systematically measured. However, studies on surface coal mines in the United States, England, France, and Canada suggest a range of 0.3 to 2.0 cubic meters per metric ton of coal mined. ${ }^{128}$ This report adopts the central value of that range and multiplies it by U.S. surface coal production.

Post-Mining Emissions. Like emissions from surface mines, post-mining emissions are not measured systematically. Thus, global average emissions factors must be relied upon. Post-mining emissions for coal mined from the surface are estimated to be very low, between 0.0 and 0.2 cubic meters per metric ton of coal mined. In contrast, post-mining emissions from underground coal are estimated to be significant, between 0.9 and 4.0 cubic meters of methane per metric ton of coal mined. ${ }^{129}$ The central values of these ranges are adopted and multiplied by annual production data for this report.

Methane Recovery for Energy. Methane recovery for energy is restricted to a small sample of mines that typically meter their gas sales. Thus, total methane recovery can be estimated from the volume and heat content of these sales.

\section{Data Sources}

Ventilation Systems in Underground Mines. Coal mine ventilation data for the approximately 200 gassiest U.S. mines was drawn from a database prepared by the Department of Interior's Bureau of Mines for the years
$1980,1985,1988,1990$, and 1993. Coal production data are reported to the Energy Information Administration on Form EIA-7A, "Coal Production Report." Basin-level emissions for non-gassy mines in 1988 were calculated by the U.S. Environmental Protection Agency. See U.S. Environmental Protection Agency, Office of Air and Radiation, Anthropogenic Methane Emissions in the United States: Estimates for 1990 (Washington, DC, April 1993), pp. 3-19-3-24.

Degasification Systems in Underground Mines. Emissions'factors for this source are derived from estimates of 1988 emissions from degasification systems prepared by the U.S. Environmental Protection Agency. See U.S. Environmental Protection Agency, Office of Air and Radiation, Anthropogenic Methane Emissions in the United States: Estimates for 1990 (Washington, DC, April 1993), pp. 3-19-3-24. Annual production figures are reported to the Energy Information Administration on Form EIA-7A, "Coal Production Report."

Surface Mines. Emissions factors for surface mines are found in the Intergovernmental Panel on Climate Change (IPCC), Greenhouse Gas Inventory Reference Manual. Coal production data are reported to the Energy Information Administration on Form EIA-7A, "Coal Production Report."

Post-Mining Emissions. Emissions factors for postmining emissions are found in the Intergovernmental Panel on Climate Change, Greenhouse Gas Inventory Reference Manual. Coal production data are reported to the Energy Information Administration on Form EIA7A, "Coal Production Report."

Methane Recovery for Energy. Volumes of methane recovered were obtained from a report prepared by the U.S. Environmental Protection Agency. See U.S. Environmental Protection Agency, Office of Air and Radiation, Identifying Opportunities for Methane Recovery at U.S. Coal Mines: Draft Profiles of Selected Gassy Underground Coal Mines (Washington, DC, September 1994), p. 6-6.

\section{Stationary Combustion}

\section{Emissions Sources}

The principal products of fuel combustion are carbon dioxide and water vapor. When fuel combustion is incomplete, methane may also be released. The volume

\footnotetext{
${ }^{127}$ M.A. Trevits, G.L. Finfinger, and J.C. LaScola, "Evaluation of U.S. Coal Mine Emission," in Society for Mining, Metallurgy and Exploration, Proceedings of the Fifth U.S. Mine Ventilation Symposium (Littlejohn Co., 1991).

${ }^{128}$ Intergovernmental Panel on Climate Change, Greenhouse Gas Inventory Reference Manual, IPCC Guidelines for National Greenhouse Gas Inventory, Vol. 3 (Paris, France, 1994), pp. 1.98-1.131.

${ }^{129}$ Intergovernmental Panel on Climate Change, Greenhouse Gas Inventory Reference Manual, IPCC Guidelines for National Greenhouse Gas Inventory, Vol. 3 (Paris, France, 1994), pp. 1.98-1.131.
} 
of methane released varies according to the efficiency and temperature of the combustion process. Most stationary sources are large, comparatively efficient boilers, such as those found in the industrial and utility sector, and thus have low levels of methane emissions. However, a significant amount of wood is consumed in residential woodstoves and fireplaces, which are typically inefficient combustion chambers. Wood combustion in these devices produces most methane emissions from stationary sources.

\section{Estimation Method}

An emissions factor based on fuel type (e.g., coal, wood, natural gas) and combustion technology (e.g., utility boiler, industrial boiler, woodstove) is applied to consumption data for each fuel and technology type.

\section{Data Sources}

Emissions coefficients for stationary fuel were obtained from the U.S. Environmental Protection Agency, Office of Air Quality Planning and Standards, Compilation of Air Pollutant Emission Factors, AP-42, Supplement D (Research Triangle Park, NC, September 1991), and the Intergovernmental Panel on Climate Change, Greenhouse Gas Inventory Reference Manual, IPCC Guidelines for National Greenhouse Gas Inventories, Vol. 3 (Paris, France, 1994). Fuel consumption data were drawn from ELA's State Energy Data Report 1993: Consumption Estimates, DOE/EIA-0214(93) (Washington, DC, May 1995), for 1980-1993; and Monthly Energy Review, DOE/EIA0035(96/07) (Washington, DC, July 1996). Residential wood fuel consumption data were derived from ELA's Renewable Energy Annual 1995, DOE/ELA-0603(95) (Washington, DC, December 1995), p. 18.

\section{Mobile Combustion}

\section{Emissions Sources}

Methane emissions from mobile combustion are, like those from stationary combustion, the result of incomplete fuel combustion. In automobiles, methane emissions result when oxygen levels in the combustion chamber drop below levels sufficient for complete combustion. The effects of incomplete combustion may be moderated somewhat by post-combustion emissions controls, such as catalytic converters. Methane emissions are also generated by fuel combustion in other modes of transport, including aircraft, ships, and locomotives. There is, however, some evidence that jet airplane engines may consume ambient methane during flight, reducing their net emissions. ${ }^{130}$

\section{Estimation Methods}

Methane emissions from highway vehicles such as automobiles, light-duty trucks, motorcycles, buses, and heavy-duty trucks are estimated by applying a per vehicle mile traveled emissions factor to vehicle use data. Because of improving technology and more stringent environmental regulations, these emissions factors vary by vehicle type and decline over time. For nonhighway sources, emissions coefficients in terms of volume of fuel consumed are applied directly to consumption data without year-to-year modifications.

\section{Data Sources}

Emissions factors for all vehicles are provided by the Intergovernmental Panel on Climate Change, Greenhouse Gas Inventory Reference Manual, IPCC Guidelines for National Greenhouse Gas Inventories, Vol. 3 (Paris, France, 1994), pp. 1.64-1.68.

The EIA collects data on miles traveled in personal transportation vehicles (cars and light-duty trucks) as part of its tri-annual Residential Transportation Energy Consumption Survey (RTECS): Energy Information Administration, Household Vehicles Energy Consumption 1994, DOE/EIA-0464(94) (Washington, DC, July 1996, and previous years). This survey contains data for the years 1983, 1985, 1988, 1991, and 1994. Emissions for intervening years were estimated by interpolating between the weighted average estimates of survey years. Vehicle miles traveled for non-household vehicles (fleets, rental cars, etc.), motorcycles, buses, and heavyduty trucks were obtained from the U.S. Department of Transportation, Federal Highway Administration, Highway Statistics 1994 (Washington, DC, 1995).

Data on fuel consumption for ships, locomotives, farm equipment, and construction equipment is available in EIA's Fuel Oil and Kerosene Sales 1994, DOE/EIA0535(94) (Washington, DC, September 1995). Fuel consumption data for jet and piston-powered aircraft are contained in EIA's Petroleum Supply Annual 1995, DOE/ EIA-0340(95)/1 (Washington, DC, May 1996). Data on fuel consumption by recreational boats are taken from S.C. Davis and S.G. Strang, Transportation Energy Data Book, Edition 15, ORNL-6856 (Oak Ridge, TN: Oak Ridge National Laboratory, Center for Transportation Analysis, May 1995).

\footnotetext{
${ }^{130}$ C.W. Spicer, M.W. Holdren, D.L. Smith, D.P. Hughes, and M.D. Smith, "Chemical Composition of Exhaust from Aircraft Turbine Engines," Journal of Engineering for Gas Turbines and Power, Vol. 114 (January 1992), pp. 111-117.
} 


\section{Landfill Methane Emissions}

\section{Emissions Sources}

After organic wastes (e.g., food, paper, yard waste) are placed in landfills they begin to decompose. Aerobic bacteria, consuming oxygen, convert organic material to carbon dioxide, heat, and water. When available oxygen is depleted, anaerobic bacteria, including methanogens, begin digesting the waste and producing methane. Methanogenic anaerobes are highly sensitive to temperature, $\cdot \mathrm{pH}$, and moisture levels, Because U.S. sanitary landfills are essentially closed systems designed to minimize entry and exit of moisture, conditions within a landfill are largely a product of the composition of the waste it contains. Thus, methane is likely to be produced at different rates and volumes both across different landfills and within a single landfill.

The biogas produced in a landfill is typically between 35 and 50 percent methane. At these levels, methane is highly explosive. Often, landfill operators will put a methane control system in place to prevent migration of high concentrations to buildings. Methane captured by control systems may be vented to the atmosphere or flared. However, captured methane is a potentially valuable energy resource. Where landfills produce steady, large volumes of methane and landfill gas-toenergy prices are competitive with other energy alternatives, recovered gas may be used as an energy resource. In most cases, the gas is converted to electricity and used for on-site energy needs or sold to local utilities. In some cases, the gas is transported via pipeline to a local end-user.

\section{Estimation Methods}

Data on methane emissions from landfills are limited to those landfills with methane recovery systems in place. For more than 100 U.S. landfills with gas recovery systems in place, Thorneloe et al. have measured or estimated methane emissions during 1992. Methane emissions from these landfills were estimated at 2.1 million metric tons for $1992{ }^{131}$ Methane emissions from landfills without gas recovery systems have not been measured, and even their number is subject to considerable uncertainty. Emissions from a given landfill are largely the product of the composition of the waste it contains and an array of site-specific factors. Waste composition data on a landfill-specific basis are nonexistent. However, national-level waste flow and waste composition data are available, and their reliability has improved over time. Thus, for this report, all waste not disposed of in a landfill with measured emissions is treated as if it has flowed to one, very large, national landfill.

To estimate methane emissions from all waste not disposed of in a landfill with measured emissions, waste volumes are subjected to a slightly modified version of the EMCON Methane Generation Model. ${ }^{132}$ This model divides the waste into three categories: readily decomposable, moderately decomposable, and slowly decomposable, each with its own set of emissions characteristics. The EMCON model provides both a high methane yield scenario and a low methane yield scenario. For each category of decomposable waste, a time lag until methane generation begins is estimated, as well as a time constant during which the methane yield of the waste is realized. The methane yield represents the total amount of methane that a given amount of waste will produce over its lifetime. For example, under a low methane yield scenario, slowly decomposing waste will begin producing methane after a 5-year lag and will continue emitting over a 40 -year period. Table A9 shows the EMCON methane generation model parameters.

Waste flows were estimated from 1940 through 1995. Waste in place in the Nation's landfills was assumed to represent the waste stream for all previous years plus the current year's additions. Those landfills examined in the Thorneloe et al. study contained 9.4 percent of the waste estimated to be in place in the Nation's landfills during 1992. This report assumes that the share of waste in these landfills and the share in all other landfills remained constant over time. Thus, the EMCON model was applied to 90.6 of the waste generated each year.

To estimate emissions from those landfills with measured data for 1992 but no data for other years, the EMCON model was recalibrated to produce the 2.1 million metric tons of measured emissions in 1992. The recalibrated model, with methane yields almost twice as large as the original, was then applied to 9.4 percent of the waste stream for all years. These much higher yields are not unexpected, as gas recovery systems are most economically employed in high-emitting landfills.

\section{Data Sources}

Franklin Associates provides estimates of municipal solid waste landfilled beginning in 1960: Franklin Associates, Ltd., Characterization of Municipal Solid Waste in the United States (annual updates prepared for the U.S. Environmental Protection Agency, Office of Solid

\footnotetext{
${ }^{131}$ S.A. Thorneloe, M.R.J. Doorn, L.A. Stefanski, M.A. Barlaz, R.L. Peer, and D.L. Epperson, "Estimate of Methane Emissions from U.S. Landfills," prepared for U.S. Environmental Protection Agency, Office of Research and Development (April 1994).

${ }^{132}$ D. Augenstein, "The Greenhouse Effect and U.S. Landfill Methane," Global Environment Change (December 1992), pP. 311-328.
} 


\begin{tabular}{|c|c|c|c|c|}
\hline Waste Category & $\begin{array}{l}\text { Decomposable Portion } \\
\text { (Percent by Dry Weight) }\end{array}$ & $\begin{array}{c}\text { Methane Yield } \\
\text { (Cubic Feet per Pound) }\end{array}$ & $\begin{array}{l}\text { Lag Time } \\
\text { (Years) }\end{array}$ & Time Constant \\
\hline \multicolumn{5}{|l|}{ High Yield (Default) } \\
\hline Readily Decomposable & 4.0 & 4.50 & 0.2 & 3 \\
\hline Moderately Decomposable ... & 45.0 & 3.55 & 1.5 & 10 \\
\hline Slowly Decomposable ....... & 5.2 & 0.50 & 5.0 & 20 \\
\hline \multicolumn{5}{|l|}{ Low Yield (Default) } \\
\hline Readily Decomposable . & 4.0 & 2.75 & 0.3 & 4 \\
\hline Moderately Decomposable ... & 45.0 & 1.95 & 2.0 & 20 \\
\hline Slowly Decomposable ....... & 5.2 & 0.29 & 5.0 & 40 \\
\hline \multicolumn{5}{|l|}{ High Yield (Modified) } \\
\hline Readily Decomposable & 4.0 & 8.82 & 0.0 & 3 \\
\hline Moderately Decomposable ... & 45.0 & 6.96 & 2.0 & 10 \\
\hline Slowly Decomposable ....... & 5.2 & 0.98 & 5.0 & 20 \\
\hline \multicolumn{5}{|l|}{ Low Yield (Modified) } \\
\hline Readily Decomposable & 4.0 & 5.39 & 0.0 & 4 \\
\hline Moderately Decomposable ... & 45.0 & 3.82 & 2.0 & 20 \\
\hline Slowly Decomposable . . . . . . & 5.2 & 0.57 & 5.0 & 40 \\
\hline
\end{tabular}

Source: D. Augenstein, "The Greenhouse Effect and U.S. Landfill Methane," Global Environmental Change (December 1992), pp. 311-328.

Waste and Emergency Response). Biocycle magazine provides estimates of waste generated, including construction and demolition waste and sludge for 19871994, in its "Nationwide Survey: The State of Garbage in America" (various years). Because Biocycle data include several categories of waste that are excluded from the Franklin Associates data, it systematically shows larger volumes of waste generated and landfilled. On average these numbers are 1.43 times those in the Franklin data. To develop a consistent data series back to 1960, the Franklin data were multiplied by 1.43 for all years (Table A10). To further extend waste generation estimates back to 1940, a regression equation relating waste generation to GNP and population was developed, and 1940-1959 waste streams were backcast.

Methane recovery data were estimated based on the measured recovery data provided by S.A. Thorneloe,
M.R.J. Doorn, L.A. Stefanski, M.A. Barlaz, R.L. Peer, and D.L. Epperson, "Estimate of Methane Emissions from U.S. Landfills," prepared for U.S. Environmental Protection Agency, Office of Research and Development (April 1994). While there were 105 known landfills with methane recovery systems in place in 1992, 130 landfills were identified as having recovery systems in place by 1994. Electricity generating capacity from these landfills was reported at 300 megawatts in 1992 and 360 megawatts in 1994 (J. Pacey, S.A. Thorneloe, and M.Doorn, "Methane Recovery from Landfills and an Overview of EPA's Research Program for Landfill Gas Utilization," presented at the 1995 Greenhouse Gas Emission and Mitigation Research Symposium, U.S. Environmental Protection Agency, Washington, DC, June 27-29, 1995). This report assumed that methane recovery and electricity capacity maintained a constant ratio and interpolated growth in intervening years lacking data points.

Table A10. U.S. Solid Waste Landfilled, 1984-1995 (Million Metric Tons)

\begin{tabular}{|c|c|c|c|c|c|c|c|c|c|c|c|c|}
\hline Item & 1984 & 1985 & 1986 & 1987 & 1988 & 1989 & 1990 & 1991 & 1992 & 1993 & 1994 & 1995 \\
\hline Waste Generated ....... & 0.0 & 0.0 & 0.0 & 0.0 & 226.8 & 244.4 & 266.4 & 254.6 & 264.7 & 278.4 & 293.0 & NA \\
\hline Waste Landfilled . . . . . . . & 192.9 & 192.1 & 197.8 & 205.0 & 208.5 & 209.5 & 210.6 & 190.3 & 170.0 & 167.5 & 165.2 & NA \\
\hline Total Waste In Place. & $5,516.2$ & $5,708.3$ & $5,906.2$ & $6,111.2$ & $6,319.7$ & $6,529.1$ & $6,739.7$ & $6,930.0$ & $7,100.0$ & $7,267.6$ & $7,432.7$ & NA \\
\hline
\end{tabular}

NA $=$ not available.

Sources: Municipal solld waste landfilled from Franklin Associates, Ltd., Characterization of Municipa/ Solid Waste in the United States, Worksheets, 1992 Update (prepared for the U.S. Environmental Protection Agency, Municipal Solid and Industrial Solid Waste Division, July 1992), Personal communication with Marjorie Franklin, Franklln Associates, Ltd., May 1994, and Blocycle, Nationwide Survey: The State of Garbage in America 1988-1994. Total MSW in place from estimates documented In Chapter 3. 


\section{Domestic and Commercial Wastewater Treatment}

\section{Emissions Sources}

Emissions of methane from the treatment of wastewater occurs when liquid waste streams containing high concentrations of organic materials are treated anaerobically (in the absence of oxygen). Anaerobic processes used in the United States are anaerobic digestion, anaerobic, and facultative (combining aerobic and anaerobic processes) stabilization lagoons, septic tanks, and cesspools. ${ }^{133}$ Treatment of wastewater solids using anaerobic digestion is the most obvious potential source of methane emissions. However, emission of significant quantities of methane from this process depends on the digester gas being vented rather than recovered or flared. Anaerobic and facultative lagoons involve retention of wastewater in impoundments where the organic materials in the wastewater undergo bacterial decomposition. The growth of algae, which absorb carbon dioxide and release oxygen as a result of photosynthesis, sustains aerobic conditions at least near the surface of the lagoon. However, the bacteria deplete oxygen at the bottom of the lagoon, producing conditions suitable for methanogenic bacteria. The extent of the resulting anaerobic zone and the associated methane generation depend on such factors as organic loadings and lagoon depth. In facultative lagoons, unlike anaerobic lagoons, a significant aerobic zone persists.

Nearly 75 percent of U.S. households are served by sewers that deliver domestic wastewater to central treatment plants. Septic tanks or cesspools treat domestic wastewater from most of the remaining households (24 percent). ${ }^{134}$ Anaerobic digestion is frequently used to treat sludge solids at U.S. municipal wastewater treatment plants. However, anecdotal evidence suggests that neither recovery nor flaring of digester gas is common in the United States, and equipment for recovery and flaring of digester gas is poorly designed or maintained, allowing most of the methane produced to be released to the atmosphere. ${ }^{135}$

\section{Estimation Method}

Insufficient information is available to develop separate estimates of methane emissions from each of the sources discussed above. Information on the type of treatment used by the thousands of municipal and industrial treatment facilities is simply not available. For instance, no reliable statistics were found for the use of anaerobic digestion at municipal treatment facilities. Knowledge regarding the emissions of methane from lagoons, septic systems, and cesspools is limited. Another difficulty is the overlap between the municipal and industrial treatment systems. Many industrial concerns discharge wastewater, which may or may not have been treated, into municipal systems. Therefore, it is necessary to base the current estimate of methane emissions from wastewater treatment on the highly simplified approach recommended by the Intergovernmental Panel on Climate Change (IPCC): ${ }^{136}$

The IPCC's simplified approach ${ }^{137}$ assumes that each person in a developed nation contributes $0.5 \mathrm{~kg}$ of $\mathrm{BOD}_{5}$ to domestic wastewater, and 15 percent of this wastewater is treated anaerobically, yielding $0.22 \mathrm{~kg}$ of methane per $\mathrm{kg}$ of $\mathrm{BOD}_{5}$ in the wastewater. ${ }^{138}$ It was assumed that recovery of methane at municipal wastewater treatment facilities is negligible.

\section{Data Source}

U.S. Census Bureau, estimate of resident population on July 1 of each year.

\section{Agricultural Sources}

\section{Enteric Fermentation in Domesticated Animals}

\section{Emissions Sources}

The breakdown of carbohydrates in the digestive track of herbivores (including insects and humans) results in the production of methane. ${ }^{139}$ The volume of methane produced from this process (enteric fermentation) is largest in those animals that possess a rumen, or forestomach, such as cattle, sheep, and goats. The

\footnotetext{
${ }^{133}$ U.S. Environmental Protection Agency, Office of Policy, Planning and Evaluation, International Anthropogenic Methane Emissions: Estimates for 1990, EPA 230-R-93-010 (Washington, DC, January 1994), p. $10-9$.

${ }^{134}$ U.S. Census, 1980, 1990.

${ }^{135}$ William Hahn, Science Applications International Corporation, personal communication (May 23, 1996).

${ }^{136}$ Intergovernmental Panel on Climate Change, Greenhouse Gas Inventory Reference Manual, IPCC Guidelines for National Greenhouse Gas Inventories, Vol. 3 (Paris, France, 1995), pp. 6.18-6.40.

${ }^{137}$ Intergovernmental Panel on Climate Change, Greenhouse Gas Inventory Reference Manual, IPCC Guidelines for National Greenhouse Gas Inventories, Vol. 3 (Paris, France, 1995), pp. 6.21-6.23.

${ }^{133}$ Biological oxygen demand (BOD) represents the oxygen consumed by bacteria to decompose organic matter contained in a wastewater stream. It provides a measure of the organic loading of wastewater, which is the primary determinant of its potential to produce methane. $\mathrm{BOD}_{5}$ is a standardized measurement of BOD that measures the oxygen consumed over a 5-day period.

${ }^{139}$ P.J. Crutzen, I. Aselmann, and W.S. Seiler, "Methane Production by Domestic Animals, Wild Ruminants, Other Herbivorous Fauna, and Humans," Tellus, Vol. 38B (1986), p. 272.
} 
forestomach allows these animals to digest large quantities of cellulose found in plant material. This digestion is accomplished by microorganisms in the rumen, some of which are methanogenic bacteria. These bacteria produce methane while removing hydrogen from the rumen. The majority (about 90 percent) of the methane produced by the methanogenic bacteria is released through normal animal respiration and eructation. The remainder is released as flatus.

\section{Estimation Method}

The level of methane emissions from enteric fermentation in domesticated animals is a function of several variables, including quantity and quality of feed intake, the growth rate of the animal, its productivity (reproduction and/or lactation), and its mobility. To estimate emissions from enteric fermentation, the animals are divided into distinct, relatively homogeneous groups. For a representative animal in each group, feed intake, growth rate, activity levels, and productivity are estimated. An emissions factor per animal is developed based on these variables. The factor is then multiplied by population data for that animal group to calculate an overall emissions estimate. The method for developing these factors differs somewhat for cattle as opposed to all other animals.

Cattle. Because emissions from cattle account for about 95 percent of U.S. emissions from enteric fermentation, they are given particular scrutiny. The U.S. cattle population is separated into dairy and beef cattle. Dairy cattle are then divided into replacement heifers $0-12$ months old, replacement heifers 12-24 months old, and mature cows. Beef cattle are divided into six classes: replacements 0-12 months old, replacements 12-24 months old, mature cows, bulls, steers and heifers raised for slaughter under the weanling system, and steers and heifers raised for slaughter under the yearling system. These populations are then multiplied by emissions factors developed for each category of cattle within the U.S. population as it was composed in 1990. ${ }^{140}$ Because characteristics critical in determining energy intake and thus emissions rates for cattle (such as growth rates and milk production) change annually, an effort to scale emissions factors to these changes is made. Emissions rates were pegged to average slaughter weights for the calves and adult cattle respectively (Table A11). ${ }^{141}$

Other Animals. For sheep, pigs, goats, and horses, populations are not disaggregated below the species level. Emissions factors for each animal group are multiplied by that group's population. Emissions factors are drawn from the work of Crutzen et al. ${ }^{142}$

\section{Data Sources}

Population and slaughter weight data for cattle, and population data for sheep and swine are provided by the U.S. Department of Agriculture (USDA), National Agricultural Statistics Service, Livestock, Dairy, and Poultry Branch. ${ }^{143}$ Population data for goats and horses are extrapolated using the information in U.S. Department of Commerce, Economics and Statistics Administration, Bureau of the Census, Census of Agriculture, United States Summary and State Data, Vol. 1, "Geographic Area Series," Part 51 (Washington, DC, 1982, 1987, and 1992).

Table A11. Average Pre-Slaughter Live Weights for U.S. Cattle and Calves, 1984-1995 (Pounds)

\begin{tabular}{|c|c|c|c|c|c|c|c|c|c|c|c|c|}
\hline Animal Class & 1984 & 1985 & 1986 & 1987 & 1988 & 1989 & 1990 & 1991 & 1992 & 1993 & 1994 & 1995 \\
\hline Cattle .............. & 1,067 & 1,098 & 1,101 & 1,105 & 1,120 & 1,134 & 1,136 & 1,163 & 1,169 & 1,161 & 1,189 & 1,183 \\
\hline Calves $\ldots \ldots \ldots \ldots$. & 230 & 234 & 239 & 239 & 252 & 260 & 281 & 346 & 376 & 388 & 384 & 372 \\
\hline
\end{tabular}

Source: U.S. Department of Agriculture, Internet Site @gopher.usda.manntib.comell.edu.

\footnotetext{
${ }^{140}$ U.S. Environmental Protection Agency, Office of Air and Radiation, Anthropogenic Methane Emissions in the United States: Estimates for 1990 (Washington, DC, April 1993), p. 5-3.

${ }^{141}$ In the U.S. Environmental Protection Agency publication Inventory of U.S. Greenhouse Gas Emissions and Sinks: 1990-1994, emissions from dairy cattle for the period 1990-1994 are scaled directly to average milk production per cow. Applying that method to data used in this report yields overall estimates roughly 0.5 percent higher than those using slaughter weights only. However, to maintain consistency with earlier estimates, this small change was viewed as negligible.

${ }^{142}$ P.J. Crutzen, I. Aselmann, and W.S. Seiler, "Methane Production by Domestic Animals, Wild Ruminants, Other Herbivorous Fauna, and Humans," Tellus, Vol. 38B (1986), pp. 274-275.

${ }^{143}$ Annual estimates of U.S. cattle, hogs, sheep, goats, poultry, and other livestock can be downloaded via the Internet from: http:// www.mannlib.cornell.edu.
} 


\section{Solid Waste of Domesticated Animals}

\section{Emissions Sources}

When the solid waste of animals is allowed to decompose under anaerobic conditions, methane is produced. The volume of methane produced varies according to the amount of organic material susceptible to decomposition within the waste (volatile solids) and the manner in which the waste is handled. Liquid-based waste management systems, in addition to providing a suitable anaerobic environment, provide the moisture necessary for methanogenic bacterial cell production and acid stabilization. ${ }^{144}$ Thus, they result in substantially higher methane emissions than dry management systems.

\section{Estimation Method}

Methane emissions from the solid waste of domesticated animals are estimated by linking emissions to the volume of solid waste produced by a given animal, the volatile solids in that waste, and the manner in which the waste is handled. The volume of waste produced is controlled by the animal's size, diet, and energy requirements. As a proxy for these variables, typical animal mass as estimated in a 1990 inventory of livestock and poultry prepared by the U.S. Environmental Protection Agency ${ }^{145}$ is used to determine waste production per animal. These animal sizes are adopted directly for all animals except cattle, whose masses are adjusted annually based on live slaughter weights as reported by the U.S. Department of Agriculture. Volatile solids produced per kilogram of animal weight and the maximum methane-producing capacity of each animal's waste are adopted from the work of Safley et al. ${ }^{146}$ For all animals except dairy cattle, the share of waste handled in each management system is also drawn from Safley et al.

Because the methods for handling the waste of dairy cattle in six States (Arizona, Florida, Nevada, North Carolina, North Dakota, and Texas) have changed since 1990 when estimates were prepared by Safley et al., the estimation method for dairy cattle differs slightly from other animals. The national average distribution of waste management techniques was applied to all dairy cattle except those in the six States listed. Individual annualized distributions were used for each of the six States. The individual States' waste management system shares were obtained from the EPA report, Inventory of U.S. Greenhouse Gas Emissions and Sinks: 1990-1994.147 After calculating emissions from dairy cattle in each of the six States, the States were totaled and added to the emissions estimate for the dairy cattle in the rest of the United States.

\section{Data Sources}

Population and slaughter weight data for cattle and population data for sheep, poultry, and swine were provided by the U.S. Department of Agriculture (USDA), Agricultural Statistics Board, in Livestock Slaughter Estimates: Annual Summary (Washington, DC, various years), and were obtained via the internet at www.mannlib.cornell.edu. Average broiler chicken populations for each year were estimated by multiplying the estimated number of broiler chickens slaughtered annually by 0.1425 , based on their 7-week life cycle, as recommended by the USDA's Economic Research Service (personal communication, May 1993). Population data for goats and horses were extrapolated using information from the U.S. Department of Commerce, Economics and Statistics Administration, Bureau of the Census, Census of Agriculture, United States Summary and State Data, Vol. 1, "Geographic Area Series," Part 51 (Washington, DC, 1982, 1987, and 1992).

\section{Rice Cultivation}

\section{Emissions Sources}

As organic material decays under anaerobic conditions in flooded rice fields, methane is produced. Between 60 and 90 percent of the methane generated is oxidized by other bacteria in the soil, and an additional portion leaches into groundwater. The majority of the methane that remains moves through rice plants by diffusive transport, to reach the atmosphere. A smaller amount of methane reaches the atmosphere by bubbling from the soil and by diffusion through the water column.

\footnotetext{
${ }^{144}$ U.S. Environmental Protection Agency, Office of Air and Radiation, Anthropogenic Methane Emissions in the United States: Estimates for 1990 (Washington, DC, April 1993).

${ }^{145}$ U.S. Environmental Protection Agency, Office of Air and Radiation, Anthropogenic Methane Emissions in the United States: Estimates for 1990 (Washington, DC, April 1993).

${ }^{146}$ L.M. Safley, M.E. Casada, J. Woodbury, and K. Roos, Global Methane Emissions from Livestock and Poultry Manure (Washington, DC: U.S. Environmental Protection Agency, February 1992), p. 18.

${ }^{147}$ U.S. Environmental Protection Agency, Office of Policy, Planning and Evaluation, Inventory of U.S. Greenhouse Gas Emissions and Sinks: 1990-1994, EPA-230-R-96-006 (Washington, DC, November 1995), Appendix D.
} 


\section{Estimation Method}

A daily emissions rate range was developed using studies of rice fields in California, ${ }^{148}$ Louisiana, ${ }^{149}$ and Texas. ${ }^{150}$ The high and low ends of the range, 0.1065 to 0.5639 grams of methane per square meter of land cultivated, were applied to the growing season length and the harvested area for each State that produces rice. In States with a second or "ratoon" crop, the additional area harvested was incorporated into estimates.

\section{Data Sources}

Rice area harvested and length of growing season data were obtained from the U.S. Department of Agriculture, National Agricultural Statistics Service, Crop Production (annual reports).

\section{Burning of Crop Residues}

\section{Emissions Sources}

Crop residues contain substantial shares of carbon, between 40 and 50 percent of dry matter. ${ }^{151}$ When crop residues are burned for fodder, land supplementation, and fuel, incomplete combustion results in methane emissions. ${ }^{152}$

\section{Estimation Method}

In keeping with the methods recommended by the Intergovernmental Panel on Climate Change, ${ }^{153}$ this report assumed that 10 percent of all crop residues are burned annually. The dry weight and carbon content of each crop was then determined and used in conjunction with estimated combustion efficiencies to derive the volume of methane emissions.

\section{Data Sources}

Sizes of crops harvested were obtained from the U.S. Department of Agriculture, National Agricultural Statistics Service, Crop Production (annual reports). Factors used to estimate emissions were derived using the sources outlined in Table A12.

\section{Industrial Processes}

\section{Chemical Production}

\section{Emissions Sources}

A wide variety of organic compounds (those containing carbon) are used as feedstocks in chemical production. High temperatures are often used to "crack" the molecular bonds of the compound, with differing temperatures producing specific chemicals. The process of cracking produces a number of chemical byproducts, including methane.

\section{Estimation Method}

The Intergovernmental Panel on Climate Change has published emissions factors for methane emitted during the manufacture of ethylene, ethylene dichloride, styrene, methanol, and carbon black ${ }^{154}$ (Table A13). Production figures for the chemicals were multiplied by those emissions factors.

\section{Data Sources}

Chemical production figures are provided by the Chemical Manufacturers Association in U.S. Chemical Industry Statistical Handbook (Washington, DC, various years).

\section{Iron and Steel Production}

\section{Emissions Sources}

Coke, sinter, and pig iron are the principal material inputs for the production of iron and steel. Coke is produced by heating coal in the absence of oxygen. One of the gaseous byproducts of this process is methane. During the next step in the production process, coke, iron ore, and flux materials are combined to form sinter. The coke is burned to create heat, causing the sinter to agglomerate. During agglomeration methane is released. Coke and iron are then added to flux materials in a blast furnace and reduced into iron, slag, and exhaust gases. Methane is one of the exhaust gases.

\footnotetext{
${ }^{148}$ R. Sass, F. Fisher, S.Lewis, M. Jund, and F. Turner, "Methane Emissions from Rice Fields: Effect of Soil Properties," Global Biogeochemical Cycles, Vol. 8 (1994), p. 135.

${ }^{149}$ R.J. Cicerone, J.D. Shetter, and C.C. Delwiche, "Seasonal Variation of Methane Flux from a California Rice Paddy," Journal of Geophysical Research, Vol. 88 (1983), pp. 7203-7209.

${ }^{150}$ C.W. Landau and P.K. Bolich, "Methane Emissions from Louisiana First and Ratoon Rice Crop," Soil Science, Vol. 156 (1993), pp. $42-48$.

${ }^{151}$ A. Strehler and W. Stutzle, "Biomass Residues," in D.O Hall and R.P. Overend (eds.), Biomass: Regenerable Energy (Chichester, UK: John Wiley and Sons, 1987), p. 85.

${ }^{152}$ These emissions are not considered to be a net release of carbon dioxide, given the uptake of carbon that occurs during the next cropping cycle's vegetative regrowth.

${ }^{153}$ Intergovernmental Panel on Climate Change, Greenhouse Gas Inventory Reference Manual, IPCC Guidelines for National Greenhouse Gas Inventories, Vol. 3 (Paris, France, 1995), p. 2.6.

${ }^{154}$ Intergovernmental Panel on Climate Change, Greenhouse Gas Inventory Reference Manual, IPCC Guidelines for National Greenhouse Gas Inventories, Vol. 3 (Paris, France, 1994), p. 2.6.
} 
Table A12. Factors Used To Estimate Methane and Nitrous Oxide Emissions from Burning of Crop Residues

\begin{tabular}{|c|c|c|c|c|}
\hline Crop Type & $\begin{array}{l}\text { Ratio of Residue to } \\
\text { Crop Volume }\end{array}$ & $\begin{array}{l}\text { Dry Matter Content. } \\
\text { (Percent) }\end{array}$ & $\begin{array}{l}\text { Carbon Content } \\
\text { (Percent) }\end{array}$ & $\begin{array}{l}\text { Nitrogen Content } \\
\text { (Percent) }\end{array}$ \\
\hline Barley $\ldots \ldots \ldots \ldots$ & 1.2 & 85.0 & 45.7 & 0.43 \\
\hline Beans $\ldots \ldots \ldots \ldots$ & 2.1 & 85.4 & ${ }^{c} 45.0$ & $\mathrm{a}_{2.30}$ \\
\hline Com $\ldots \ldots \ldots \ldots$ & 1.0 & 78.0 & 47.1 & 0.81 \\
\hline Oats $\ldots \ldots \ldots \ldots$ & 1.3 & $b_{90.1}$ & $a_{42.0}$ & ${ }^{\mathrm{a}} 0.84$ \\
\hline Peas $\ldots \ldots \ldots \ldots$. . . & 1.5 & $b_{90.2}$ & $c^{c} 45.0$ & $c_{2.30}$ \\
\hline Peanuts...$\ldots \ldots$. & 1.0 & 90.1 & ${ }^{c} 42.3$ & $c_{1.10}$ \\
\hline Potatoes . . . . . . . . . & 0.4 & ${ }^{\circ} 86.7$ & 42.3 & 1.10 \\
\hline Rice $\ldots \ldots \ldots \ldots$. & 1.4 & 85.0 & 41.4 & 0.67 \\
\hline Rye $\ldots \ldots \ldots \ldots$ & 1.6 & $c_{90.0}$ & $c^{c} 48.5$ & $c_{0.70}$ \\
\hline Sorghum $\ldots \ldots \ldots$ & 1.4 & 88.0 & $\mathrm{a}_{34.0}$ & $\mathrm{~d}_{0.85}$ \\
\hline Soybeans ......... & 2.1 & 86.7 & ${ }^{a} 44.0$ & $d_{2.30}$ \\
\hline Sugar Beets . . . . . . . & 0.2 & ${ }^{\mathrm{c}} 90.0$ & 40.7 & 2.28 \\
\hline Sugar Cane $\ldots \ldots \ldots$ & 1.2 & 37.2 & 47.0 & 0.19 \\
\hline Wheat $\ldots \ldots \ldots \ldots$ & 1.3 & 85.0 & 48.5 & 0.28 \\
\hline
\end{tabular}

Sources: A. Strehler and W. Stutzle, "Biomass Residues," in D. Hall and R. Overend (eds.), Biomass: Regenerable Energy (Chichester, UK: John Wiley and Sons, 1987), except where indicated by: (a) C. Li, S. Frolking, and R. Harriss, "Modeling Carbon Biogeochemistry in Agricultural Soils," Global Biogeochemical Cycles, Vol. 8 (September 1994); (b) E. Darley, Emission Factors from Buming Agricultural Wastes Collected in California, Final Report, CALARB Project 4-011 (Riverside, CA: University of California, 1977); (c) U.S. Environmental Protection Agency, Office of Policy, Planning and Evaluation, Inventory of U.S. Greenhouse Gas Emissions and Sinks: 1990-1993, EPA 230-R-94-014 (Washington, DC, September 1994); (d) G. Barnard, "Use of Agricultural Residues as Fuel," in J. Pasztor and L. Kristoferson (eds.), Bioenergy and the Environment (Boulder, CO: Westview Press, 1990).

Table A13. Methane Emissions Factors for Industrial Processes

(Grams of Methane Emitted per Kilogram of Product Produced)

\begin{tabular}{l|c}
\hline \multicolumn{1}{c|}{ Industrial Product } & Methane Emissions Factor \\
\hline Coke $\ldots \ldots \ldots \ldots \ldots \ldots \ldots$ & 0.5 \\
Sinter $\ldots \ldots \ldots \ldots \ldots \ldots$ & 0.5 \\
Pig Iron $\ldots \ldots \ldots \ldots \ldots$ & 0.9 \\
Carbon Black $\ldots \ldots \ldots \ldots$ & 11.0 \\
Ethylene $\ldots \ldots \ldots \ldots \ldots$ & 1.0 \\
Dichloroethylene $\ldots \ldots \ldots$ & 0.4 \\
Styrene $\ldots \ldots \ldots \ldots \ldots$ & 4.0 \\
Methanol . . . . & 2.0 \\
\hline
\end{tabular}

Source: Intergovernmental Panel on Climate Change, Greenhouse Gas Inventory Reference Manual, IPCC Guidelines for National Greenhouse Gas Inventories, Vol. 3, p. 2.6.

\section{Estimation Method}

The Intergovernmental Panel on Climate Change has published emissions factors for methane emitted during the production of coke, sinter, and pig iron. ${ }^{155}$ Production figures for iron and steel inputs were multiplied by those emissions factors.

\section{Data Sources}

Coke, sinter, and pig iron production data are published annually by the American Iron and Steel Institute in its Annual Statistical Report (Washington, DC, various years).

\section{Nitrous Oxide}

Most anthropogenic nitrous oxide emissions in the United States can be attributed to agricultural and energy-related sources. 'In 'particular, fertilizer use (which amplifies the natural flux of nitrous oxide from soil) and vehicular fuel combustion combine to account for approximately 70 percent of estimated emissions (although the range of uncertainty associated with emissions from fertilizer use is quite large). Emissions estimates in this report include fertilizer application; burning of crop residues; mobile source combustion from passenger cars, buses, motorcycles, trucks, and other minor sources; stationary source combustion from residential, industrial, and electric utility energy use; and industrial production of adipic acid and nitric acid.

\footnotetext{
${ }^{155}$ Intergovernmental Panel on Climate Change, Greenhouse Gas Inventory Reference Manual, IPCC Guidelines for National Greenhouse Gas Inventories, Vol. 3 (Paris, France, 1994), p. 2.6.
} 


\section{Energy Use}

\section{Mobile Combustion}

\section{Emissions Sources}

Nitrous oxide emissions are produced as a byproduct of fuel combustion. During combustion, nitrous oxide is produced as a result of chemical interactions between nitric oxide and other combustion products. With most conventional combustion systems, high temperatures limit the quantity of nitrous oxide that escapes; therefore, emissions from these systems are typically low. Mobile sources of fuel combustion include passenger cars, buses, motorcycles, light-duty and other trucks, air, rail, and water transportation sources, and farm and construction equipment.

\section{Estimation Method}

See section on methane emissions from mobile combustion, above.

\section{Stationary Combustion}

\section{Emissions Sources}

As with mobile sources, nitrous oxide emissions are produced as a byproduct of fuel combustion. The three fuels of primary importance burned by stationary sources are coal, fuel oil, and natural gas. Combustion systems powered by coal produce the most nitrous oxide, approximately 76 percent of annual emissions. As a sector, electric utilities consistently account for more than one-half of total emissions. Other important sources are commercial facilities, industrial facilities, and residences.

\section{Estimation Method}

Nitrous oxide emissions from stationary combustion are estimated by multiplying fuel consumption figures for each fuel type and stationary source by emissions factors for each type of fuel. The emissions factors used in this report differ from those used in previous years; therefore, emissions estimates may also be different from those presented in last year's report. Emissions were estimated by applying emissions factors for coal, oil, and natural gas to EIA's consumption data for each of those fuels in the commercial, residential, industrial, and electric utility sectors.

\section{Data Sources}

Fuel consumption data are from the Energy Information Administration, State Energy Data Report 1993, DOE/ EIA-0214(93); and Monthly Energy Review, DOE/EIA0035(96/03) (Washington, DC, March 1996).

The emissions factors used in this report are those recommended by the IPCC as derived from studies of numerous conventional systems: G.G. De Soete, "Nitrous Oxide from Combustion and Industry: Chemistry, Emissions and Control," in A.R. van Amstel (ed.), International IPCC Workshop Proceedings: Methane and Nitrous Oxide, Methods in National Emissions Inventories and Options for Control (Bilthoven, Netherlands: RIVM, 1993), pp. 287-337.

\section{Agriculture}

\section{Fertilizer Use}

\section{Emissions Sources}

Nitrous oxide uptake and emissions occur naturally as a result of nitrification and denitrification processes in soil. When nitrogen-based fertilizers are added to the soil, emissions generally increase, unless application precisely matches plant uptake and soil capture. ${ }^{156} \mathrm{~A}$ variety of other factors, including certain soil properties and moisture content, are known to influence the rate of emissions. Although these factors have been identified, they have not been systematically quantified, and we are not aware of data that would allow them to be incorporated into emissions estimates.

\section{Estimation Method}

Emissions factors ranging in order of magnitude from 0.001 to 0.1 grams of nitrogen (in nitrous oxide) per gram of nitrogen in fertilizer were applied to the nitrogen content of fertilizer consumed annually in the United States, producing low, median, and high estimates. In 1995, the median estimate (which assumes that 1 percent of the nitrogen in fertilizer is emitted as nitrous oxide-also the percentage recommended by the IPCC ${ }^{157}$ ) indicates that 167,000 metric tons of nitrous oxide was released into the atmosphere as a result of fertilization practices.

\footnotetext{
${ }^{156}$ A.F. Bouwman, "Exchange of Greenhouse Gases Between Terrestrial Ecosystems and the Atmosphere," in A.F. Bouwman (ed.), Soils and the Greenhouse Effect (New York, NY: John Wiley and Sons, 1990).

${ }^{157}$ Intergovernmental Panel on Climate Change, Greenhouse Gas Inventory Reference Manual, IPCC Guidelines for National Greenhouse Gas Inventories, Vol. 3 (Paris, France, 1994), p. 4.77.
} 


\section{Data Sources}

Estimates of total U.S. fertilizer consumption were obtained from reports from the Tennessee Valley Authority Fertilizer Research Center for various years through 1994: J.T. Berry et al., Commercial Fertilizers (Muscle Shoals, AL: Tennessee Valley Authority, Fertilizer Research Center, Reports for 1986-1991, 1993-1994).

Estimates for prior years have been modified from those in last year's report to represent the nitrogen content of annual fertilizer consumption for the calendar year. The emissions factor for nitrous oxide is taken from A.R. Mosier, "Nitrous Oxide Emissions from Agricultural Soils," in A.R. van Amstel (ed.), International IPCC Workshop Proceedings: Methane and Nitrous Oxide, Methods in National Emissions Inventories and Options for Control (Bilthoven, Netherlands: RIVM, 1993), p. 281.

\section{Crop Residue Burning}

\section{Emissions Sources}

Crop residue is commonly disposed of by incorporation into the soil, spreading over the soil surface to prevent erosion, as animal bedding, or through burning. Burning crop residue releases nitroús oxide into the atmosphere. The burning of crop residue occurs throughout the United States, although it is illegal in certain areas. There are no accurate estimates of the amount of crop residue burned in the United States.

\section{Estimation Method and Data Sources}

See section on methane emissions from burning crop residues, above.

\section{Industrial Processes}

\section{Adipic Acid Production}

\section{Emissions Sources}

Manufacture of adipic acid is one of the two principal sources of nitrous oxide from industrial processes. Adipic acid is used primarily in the manufacture of nylon fibers and plastics in carpet yarn, clothing, and tire cord. Other uses of adipic acid include production of plasticizers for polyvinyl chloride and polyurethane resins, lubricants, insecticides, and dyes. In the United States, three companies, which operate a total of four plants, manufacture adipic acid by oxidizing a ketonealcohol mixture with nitric acid. Creation of nitrous oxide is an intrinsic byproduct of this chemical reaction.

\section{Estimation Method}

Emissions of nitrous oxide from production of adipic acid are calculated by multiplying adipic acid production figures by nitrous oxide emissions coefficients. For every metric ton of adipic acid produced, 0.3 metric ton of nitrous oxide is created. ${ }^{158}$ Currently, two plants (accounting for approximately 77 percent of total production) control emissions by thermally decomposing the nitrous oxide, and 98 percent of the potential emissions from those plants are eliminated by this technique. ${ }^{159}$

\section{Data Sources}

Adipic acid production figures are from Chemical and Engineering News, annual report on the "Top 50 Industrial Chemicals" (April issue, various years).

The adipic acid emissions coefficient is from $M$. Thiemens and W. Trogler, "Nylon Production: An Unknown Source of Atmospheric Nitrous Oxide," Science, Vol. 251 (February 22, 1991), p. 932.

\section{Nitric Acid Production}

\section{Emissions Sources}

Nitric acid is a primary ingredient in fertilizers. The process for manufacturing this acid involves oxidizing ammonia $\left(\mathrm{NH}_{3}\right)$ with a platinum catalyst. Nitrous oxide emissions are a direct result of the oxidation.

\section{Estimation Method}

Measurements at a DuPont plant indicate emissions factors of 2 to 9 grams of nitrous oxide per kilogram of nitric acid manufactured. ${ }^{160}$ The emissions estimates presented in this report were calculated by multiplying the annual quantity of nitric acid produced by the midpoint (5.5 grams nitrous oxide per kilogram of product) of the emissions range determined at the DuPont plant. There is, however, a considerable degree of uncertainty associated with this estimate, because-the emissions factor for the DuPont plant may not in fact be generalizable across the industry.

\section{Data Sources}

Nitric acid production figures are from the Chemical Manufacturers Association, Chemical Industry Statistical Handbook (Washington, DC, 1995).

\footnotetext{
${ }^{158}$ M.H. Thiemens and W.C. Trogler, "Nylon Production: An Unknown Source of Atmospheric Nitrous Oxide," Science, Vol. 251, No. 4996 (February 1991).

${ }^{159}$ Radian Corporation, Nitrous Oxide Emissions from Adipic Acid Manufacturing (Rochester, NY, January 1992), p. 10.

${ }^{160}$ R.A. Reimer, R.A. Parrett, and C.S. Slaten, "Abatement of $\mathrm{N}_{2} \mathrm{O}$ Emission Produced in Adipic Acid," in Proceedings of the Fifth International Workshop on Nitrous Oxide Emissions (Tsukuba, Japan, July 1992).
} 
The nitric acid emissions coefficient is from the Intergovernmental Panel on Climate Change, Greenhouse Gas Inventory Reference Manual, IPCC Guidelines for National Greenhouse Gas Inventories, Vol. 3 (Paris, France, 1995), p. 2.9.

\section{Halocarbons and Other Gases}

\section{Emissions Sources}

Halocarbons and other gases have hundreds of uses, but the bulk of emissions come from a few broad categories of use:

- As a refrigerant or working fluid in air conditioning and refrigeration equipment

- As a solvent in various industrial processes

- As a blowing agent for making insulating foams

- As a fugitive emission from various industrial processes, including the manufacture of halocarbons.

The emissions profile differs for each emissions source. Refrigerants are used in a closed cycle inside cooling equipment, and they tend to leak out when the equipment is scrapped or serviced. Some portion of the refrigerants is captured and recycled or destroyed, rather than emitted, when equipment is serviced. Halocarbons in solvent applications are often recycled, but net consumption (after recycling) is probably a good indicator of emissions. Halocarbons used as blowing agents can be characterized by the type of foam manufactured: halocarbons used to make "open cell" foam are released to the atmosphere immediately, while halocarbons used to make "closed cell" foam are trapped within the foam for the life of the foam, which can vary (depending on the use) from a few weeks to many years.

\section{Estimation Method}

In general, the EIA has relied on estimates of halocarbon emissions published by the EPA. However, the EPA has not prepared estimates for all years and all gases. The EIA has therefore extended EPA emissions estimates using various methods.

In general, estimating emissions of halocarbons begins with determining the level of annual consumption of the halocarbon and distributing consumption across the principal end-use applications. Emissions from each end-use application are then computed, based on the assumed emissions characteristics of the application. Alternatively, industrial emissions from large corporations can be determined directly for some chemicals by reference to companies' reporting under the EPA's Toxics Release Inventory (TRI).

In a few important cases, emissions factors for fugitive emissions from industrial processes have been developed: HFC-23 emissions from HCFC-22 manufacture (4 percent of HCFC-22 production) and perfluoromethane and perfluoroethane emissions from aluminum smelting $\left(0.6 \mathrm{~kg} \mathrm{CF}_{4}\right.$ per metric ton aluminum and $0.06 \mathrm{~kg}$ $\mathrm{C}_{2} \mathrm{~F}_{6}$ per metric ton aluminum). In these cases, emissions can be calculated by multiplying the underlying activity factor by the emissions factor.

Finally, emissions of HFC-134a were estimated by multiplying the number of vehicles manufactured that use HFC-134a as a refrigerant by estimated charge sizes and leakage rates provided by personal communications with Ford and General Motors.

\section{Data Sources}

EPA estimates of emissions of halocarbons and other gases can be found in U.S. Environmental Protection Agency, Inventory of U.S. Greenhouse Gas Emissions and Sinks: 1990-1994, EPA-230-R-96-006 (Washington, DC, November 1995).

Information on halocarbon production, consumption, and sales is spotty. Information on production and sales of some compounds is provided in U.S. International Trade Commission, Synthetic Organic Chemicals: United States Production and Sales, 1994, USITC Publication 2933 (Washington, DC, November 1995). The Alternative Fluorocarbons Environmental Acceptability Study (AFEAS) provides information on "world" and "northern hemisphere" production, sales, and emissions of certain halocarbons, as well as a breakdown of sales by anticipated end use: Alternative Fluorocarbons Environmental Acceptability Study, Production, Sales and Atmospheric Release of Fluorocarbons Through 1994 (Washington, DC, October 1995). The end-use share data can be used to (crudely) estimate U.S. consumption for particular types of end uses. Large industrial emitters of certain halocarbons are required to report emissions, destruction, and recycling of these compounds. This information is published in U.S. Environmental Protection Agency, 1994 Toxics Release Inventory: Public Data Release (Washington, DC, July 1996).

Emissions factors for HFC-23, perfluoroethane, and perfluoromethane can be found in U.S. Environmental Protection Agency, Inventory of U.S. Greenhouse Gases Emissions and Sinks: 1990-1993, EPA-230-R-94-014 (Washington, DC, September 1994), p. 38. 


\section{Criteria Pollutants}

The estimates presented in this report are taken directly from the Environmental Protection Agency's report, National Air Pollutant. Emission Trends: 1990-1994, EPA454/R-95-011. Chapter 6 of the EPA report summarizes the methodologies used in estimating emissions and revisions to these methodologies as they have occurred. Since the information is too extensive to be included here, only a simplified description is provided below.

Emissions were calculated either for individual sources or for many sources combined, using basic activity data as indicators of trends. The national activity data used to calculate the individual source categories were obtained from many different sources. Activity data are used in conjunction with emissions factors, which relate the quantity of emissions to the activity, and assumptions about control efficiency. Emissions factors are generally available from the Environmental Protection Agency's Compilation of Air Pollutant Emission Factors, $\mathrm{AP}-42$, often referred to as the AP-42 emissions factors. The EPA currently derives the overall emissions control efficiency of a source category from a variety of sources, including published reports, the 1985 NAPAP (National Acid Precipitation and Assessment Program) emissions inventory, and other EPA databases.

\section{Data Sources}

U.S. Environmental Protection Agency, National Air Pollutant Emission Trends, EPA-454-R-95-011 (Research Triangle Park, NC, October 1995). See also: http:// www.epa.gov/oar/emtrnd94/emtrnd94.html.

\section{Land Use Issues}

A large amount of carbon, on the order of 100 million metric tons, is removed from the atmosphere (sequestered) by forest land in the United States each year. An additional 12 million metric tons is locked into longterm storage in wood products, and approximately 15 million metric tons of carbon enters landfills in the form of wood and paper waste, where processes that cause the carbon to be released to the atmosphere may take up to 60 years or longer.

Less well understood or quantifiable are the impacts of the various types of land uses on other greenhouse gases. Chapter 7 and this section also briefly discuss methane emissions from wetlands, as well as methane and nitrous oxide emissions (and uptake) from forest land, grassland, cropland, pasture, and rangeland. It appears that methane and nitrous oxide emissions attributable to changes in land use in the United States are relatively small, making a negligible contribution to GWP-weighted concentrations of greenhouse gases in the atmosphere. However, there is considerable uncertainty associated with estimates of land-use-related emissions of these gases.

\section{Carbon Sequestration}

\section{Carbon Cycling in Forests}

\section{Sequestration/Emissions Sources}

Every year in the United States and throughout the world a large amount of carbon dioxide is removed from the atmosphere and sequestered into biomass. At the same time, carbon is released to the atmosphere from vegetative respiration, combustion of wood as fuel, degradation of manufactured wood products, consumption of biomass by herbivores, and the natural decay of expired vegetation.

Changes in forest land have a more important impact on U.S. anthropogenic contributions to greenhouse gas emissions than changes in any other type of land. Forests sequester atmospheric carbon in biomass and soil. Photosynthesis is responsible for sequestering carbon into live vegetation, while mortality of roots, foliage, and stems and branches adds carbon to the soil.

On average, the amount of carbon stored in U.S. forests is 17.7 kilograms per square meter of forest land (using an estimate by Forest Service Researcher Richard Birdsey). The range in forest storage across States is large: from 9 kilograms per square meter in Nevada to 26 kilograms per square meter in Alaska, according to Birdsey. ${ }^{161}$

The opposite of photosynthesis is respiration, the release of carbon to the atmosphere through decomposition of dead biomass and as a byproduct of internal mechanisms within living plants. Trees add new cell layers each year. Old and new cells require energy for maintenance. Growth and increased maintenance cause respiration to increase. Eventually, because of limitations to total tree foliage area, the rate of photosynthesis cannot continue to outpace respiration, and trees pass through a stage of rough equilibrium between photosynthesis and respiration. When respiration exceeds photosynthesis, mortality follows. This causes the cycle to shift into reverse, as stored carbon in individual trees is released through decay (which is utilized by new trees that emerge in place of the dead and dying ones). The cycle is somewhat different at the

\footnotetext{
${ }^{161}$ R.A. Birdsey, Carbon Storage and Accumulation in United States Forest Ecosystems, U.S. Forest Service General Technical Report WO-59 (Washington, DC, 1992), p. 3.
} 
forest level, where continual additions to soil carbon from decaying biomass can result in the forest remaining an active carbon sink.

Carbon is also sequestered in wood products and landfills. Forests produce a number of wood products, most notably lumber and paper. Carbon in lumber may remain sequestered for decades or centuries, depending on the end use of the product. Carbon in paper products and wood products that are landfilled may remain sequestered for long periods of time, although no accurate national estimates have been made on the retention time of carbon in landfilled waste.

\section{Estimation Method}

Estimates of carbon uptake and release by U.S. forests are made by multiplying biomass volume growth rates from compilations of national forest inventories and ecosystem studies by associated carbon sequestration rates based on estimates of the carbon content of the biomass of various forest types. Forest statistics include acreage and age of distinct forest types, and carbon sequestration rates are based on biomass equations developed in several ecosystem studies conducted throughout the United States. National forest acreages, ages, and forest types are obtained from periodic assessments conducted by the U.S. Department of Agriculture.

The carbon flux estimates presented in this report are based on statistics for the coterminous United States, thus excluding Alaska and Hawaii, for which adequate statistics are lacking. Carbon sequestration estimates include carbon flux by live trees and other vegetation, "dead" flux of carbon entering the soil, and fluxes of carbon to wood products and landfills. A considerable amount of carbon enters the soil, the forest floor, and understory vegetation, which, aside from living trees, are the other major repositories of organic carbon in forest ecosystems. Estimates of carbon storage in trees were based on periodic forest inventories designed to provide estimates of timber volume, growth, removals and mortality. ${ }^{162}$ Above-ground tree biomass was calculated by multiplying estimated timber volumes by conversion factors derived from the national biomass inventory. ${ }^{163}$
Birdsey and Heath's estimates of total acreages of distinct types of forest land are obtained from the U.S. Department of Agriculture, which is required to conduct comprehensive assessments of all forest and range land resources on both public and private lands under the Forest and Rangeland Renewable Resources Planning Act (RPA) of 1974. The Forest Service collects information on the Nation's timber resources from four regions. Each region is composed of subregions, for a total of nine subregions nationally. Each subregion periodically collects local estimates of forest resources. The average cycle of periodic surveys nationally is 10 years. Because the Forest Service produces RPA assessment updates every 5 years, it is assumed that approximately one-half of the information contained in each update is new, and one-half is old. The last RPA update was published in 1992; accordingly, the estimates of carbon sequestration in Chapter 7 are for 1992. The next RPA assessment will occur in 1997, and the report will not be available until some time in 1998. Hence, carbon sequestration estimates for years after 1992 are not likely to be available until 1998 or 1999 (although projections based on previous trends have already been made).

The estimate of total carbon flux from U.S. forests is somewhat higher in this report than in a similar report released by the U.S. Environmental Protection Agency. ${ }^{164}$ The EPA, also citing Birdsey and Heath, estimated total flux at 125 million metric tons, excluding the soil carbon flux estimated by Birdsey and Heath.

The amount of carbon sequestered in wood products and landfills has also been estimated by Birdsey and Heath, although the estimates are sensitive to assumptions about recycling, age of trees at harvest, and other factors that affect the amount of wood and the retention periods in various pools. In addition, the estimates of carbon sequestration into these pools understate actual sequestration by an unknown, but probably large, degree, as Birdsey and Heath's estimates include only wood product and landfill sequestration from biomass produced on private timberland. Inclusion of biomass from other timberland, such as Federally owned timberland, would raise total carbon sequestration estimates considerably.

\footnotetext{
${ }^{162}$ K.L. Waddell, D. Oswald, D. Daniel, Powell, and S. Douglas, Forest Statistics of the United States, 1987, USDA Forest Service Resource Bulletin PNW-RB-168 (Pacific Northwest Research Station, Portland, OR, 1989).

${ }^{163}$ N.D. Cost, J. Howard, and B. Mead, W.H. McWilliams, W.B. Smith, D.D. Van Hooser, and E.H. Wharton, The Biomass Resource of the United States, USDA Forest Service General Technical Report WO-57 (1990).

${ }^{164}$ U.S. Environmental Protection Agency, Office of Policy, Planning and Evaluation, Inventory of U.S. Greenhouse Gas Emissions and Sinks: 1990-1994, EPA-230-R-96-006 (Washington, DC, 1995).
} 


\section{Other Land Use Changes Affecting the Carbon Budget}

It is difficult to be specific about how much carbon might be gained or lost through transformations of grasslands and pasturelands to croplands. Typical estimates of the amount of soil carbon lost when pastureland or grassland is converted to cropland are approximately 30 percent of the amount in place at the time of conversion. These losses can be expected to take place over a period of 20 years, or longer, following conversion. Although the amount of carbon in a square meter of forest might be on the order of 9 to 26 kilograms, depending on the condition of the forest and the age and type of trees growing, typical estimates of carbon storage in cultivated lands range from 1 to 8 kilograms per square meter, and estimates for uncultivated (but cultivatable) lands range from 2 to 10 kilograms per square meter. ${ }^{165}$ Thus, there is less carbon to be gained or lost, and the range of possible outcomes per unit of land is consequently smaller. Soils initially very low in carbon tend to gain slight amounts of carbon after cultivation, but richer soils tend to lose at least 20 percent of their carbon after cultivation begins.

A study commissioned by the EPA estimated average soil carbon content for an area of 272 million acres of farmland in the United States at 4.8 to 7.9 kilograms per square meter. ${ }^{166}$ The study estimated that 1.0 billion to 1.6 billion metric tons of soil carbon had been lost from the farmland since it had been placed in cultivation, equivalent to 16 percent of the estimated original carbon content of the soil. The study also noted, however, that land with a soil carbon content of less than 4 kilograms per square meter was generally not being cultivated at the time of the study.

It would not be surprising if the least fertile farmland were the most likely to be removed from cultivation. Therefore, assuming that no trees are planted or naturally regenerate, the carbon gains from idling cropland, are likely to be small. However, converting farmland to forest produces relatively large carbon gains, both through the addition of biomass (i.e., carbon stored in trees) and through the accretion of carbon into the soil, as dead limbs, trees, and roots gradually decay above and below ground.

\section{Data Sources}

The primary researchers who have combined State and national level forestry statistics with biomass growth equations to determine total national carbon fluxes are USDA Forest Service researchers Richard Birdsey and Linda Heath. Their findings have been presented in the following technical reports, and are one of the two sources of data for carbon flux estimates presented in this report: 'R.A. Birdsey and L.S. Heath, "Carbon Changes in U.S. Forests," in L.A. Joyce (ed.), Productivity of America's Forests and Climate Change, General Technical Report RM-GTR-271 (Fort Collins, CO: USDA Forest Service, 1995); and R.A. Birdsey, Carbon Storage and Accumulation in United States Forest Ecosystems and "Changes in Forest Carbon Storage from Increasing Forest Area and Timber Growth," in R.N. Sampson and D. Hair (eds.), Forests and Global Change, Vol. 1, "Opportunities for Increasing Forest Cover, American Forests" (Washington, DC).

Birdsey and Heath's estimates of total acreages of distinct types of forest land are obtained from the U.S. Department of Agriculture: K.L. Waddell, D. Oswald, D. Daniel, Powell, and S. Douglas, Forest Statistics of the United States, 1987, USDA Forest Service Resource Bulletin PNW-RB-168 (Portland, OR, 1989).

Carbon storage and flux by distinct forest types have been estimated by several Forest Service researchers: N.D. Cost, J. Howard, B. Mead, et al., The Biomass Resource of the United States, USDA Forest Service General Technical Report WO-57 (1990); D.S. Powell, J.L. Faulkner, D.R. Darr, et al., Forest Resources of the United States, 1992, USDA Forest Service General Technical Report RM-234 (Fort Collins, CO, 1993); and K.L. Waddell, D. Oswald, D. Daniel, Powell, and S. Douglas, Forest Statistics of the United States, 1987, USDA Forest Service Resource Bulletin PNW-RB-168 (Portland, OR, 1989).

Heath and Birdsey are also the source of EIA's estimate of carbon flux to wood products and landfills: L.S. Heath, R.A. Birdsey, and C. Row, "Carbon Pools and Flux in U.S. Forest Products," in The Role of Forest Ecosystems and Forest Resource Management in the Global Carbon Cycle, NATO ASI Series (Berlin, Germany: Springer-Verlag, 1995).

\footnotetext{
${ }^{165}$ See the scattergram in L.K. Mann, "Changes in Soil Carbon Storage After Cultivation," Soil Science, Vol. 142, No. 5 (November 1986), p. 284.

${ }^{166}$ ManTech Environmental Technology, Inc., Impact of Conservation Tillage on Soil and Atmospheric Carbon in the Contiguous United States, PB92-113448, prepared for the Corvallis Environmental Research Laboratory, U.S. Environmental Protection Agency (September 1991), p. 7.
} 
For information on carbon storage after converting land to cultivated land, see L.K. Mann, "Changes in Soil Carbon Storage After Cultivation," Soil Science, Vol. 142, No. 5 (November 1986), p. 279; and W.H. Schlesinger, "Changes in Soil Carbon Storage and Associated Properties with Disturbance and Recovery," in J. Trabalka and D. Riechle (eds.), The Changing Carbon Cycle: $A$ Global Analysis (New York: Springer-Verlag, 1986), p. 12.

\section{Changes in Land Use}

\section{Estimation Method}

Estimates of the total U.S. land area occupied by different types of land use form part of the basis for estimating greenhouse gas emissions and sequestration from changes in land use. The primary source of information used for EIA's land use figures is the Economic Research Service (ERS) of the U.S. Department of Agriculture. The ERS has regularly inventoried the major uses of land in the United States at intervals coinciding with the censuses of agriculture since 1945. The latest inventory was conducted in 1992.
There is an unquantified amount of error associated with national-level land use statistics. Data are typically obtained from surveys differing greatly in scope, methods, definitions, and other characteristics. Individual sources account for only a limited part of the total land area. The available data contain conflicts and overlap that must be reconciled or removed. The ERS addresses these problems to the extent feasible, but there is undoubtedly some error associated with combining and normalizing land use data encompassing approximately 2.3 billion acres.

\section{Data Sources}

The ERS compiles land use data in its periodic report Major Uses of Land in the United States. The estimates in the ERS report are from a series of land-use inventories, based on available land-use data from a wide variety of sources, conducted by the ERS and predecessor agencies. See, for example, A.B. Daugherty, Major Uses of Land in the United States, 1992, USDA Economic Research Service Agricultural Economic Report Number 723 (Washington, DC, 1995). 



\section{Appendix B Carbon Coefficients Used in This Report}

\section{Overview}

In the October 1994 edition of Emissions of Greenhouse Gases in the United States, the Energy Information Administration developed new emissions coefficients for estimating carbon released from the combustion of fossil fuels in the United States. Emissions coefficients for more than 20 petroleum products were derived, based on their density, heat content, and carbon share. These variables were estimated from the underlying chemical composition of the fuels and, where available, ultimate analyses of product samples. ${ }^{167}$ (For a more detailed discussion of how emissions coefficients for fossil fuels were derived, see Appendix A in the 1994 report.) ${ }^{168}$

The composition of marketed petroleum products varies over time due to changes in exploration, recovery, and refining technology, economic changes (e.g., changes in the price of oil), or regulatory changes (e.g., requirements for reformulated gasoline in the Clean Air Act Amendments of 1990). To capture the effects of these changes, the emissions coefficients for several important petroleum products have been annualized. The emissions coefficients for motor gasoline, jet fuel, crude oil, and liquefied petroleum gas now vary over time, reflecting changes in their composition and density.

Appendix A of the October 1995 edition of Emissions of Greenhouse Gases in the United States discusses the development of these annualized coefficients in more detail. ${ }^{169}$ That appendix also describes revisions in the emissions coefficients for jet fuel and liquefied petroleum gases from those found in the 1994 report. The jet fuel coefficient was revised based on 39 jet fuel samples analyzed by Boeing that were more representative of the fuel currently in use than those samples previously used. ${ }^{170}$ The emissions coefficient for liquefied petroleum gas (LPG) was revised to reflect the four paraffinic hydrocarbons included in the EIA taxonomy of LPG: ethane, propane, isobutane, and $n$-butane. The coefficient developed for the 1994 report had erroneously included pentanes-plus in the LPG category along with the four compounds listed above.

The most important development addressed in this appendix is the calculation of an emissions coefficient for motor gasoline consumed in 1995. For the first time, the effect on carbon emissions of the requirement for reformulated gasoline is quantified. The Clean Air Act Amendments mandated the use of reformulated gasoline in heavily polluted areas beginning in 1995. The impact of this legislation is substantial, with reformulated gasoline representing approximately 25 percent of motor gasoline production in 1995. Some studies predict that the share of reformulated gasoline may grow substantially by 2000 to as much as 100 percent of the gasoline market. ${ }^{171}$ Reformulated gasoline has an emissions coefficient about 1 percent lower than typical gasoline. Thus, if the entire gasoline market consisted of reformulated gasoline, U.S. carbon emissions could be reduced by nearly 3 million metric tons. However, because reformulated gasoline contains less energy per gallon than typical gasoline, more gallons must be consumed to travel the same distance. While this will not affect estimates of carbon emissions, because they are calculated on an energy consumed basis, fuel consumption (measured in gallons or barrels) may increase. ${ }^{172}$

\footnotetext{
${ }^{167}$ An ultimate analysis provides a detailed breakdown of the chemical composition of a mixture.

${ }^{168}$ Energy Information Administration, Emissions of Greenhouse Gases in the United States 1987-1992, DOE/EIA-0573 (Washington, DC, November 1994), pp. 73-92.

${ }^{169}$ Energy Information Administration, Emissions of Greenhouse Gases in the United States 1987-1994, DOE/EIA-0573 (Washington, DC, October 1995), pp. 75-90.

${ }^{170}$ O.J. Hadaller and O.M. Momenthy, The Characteristics of Future Fuels, Part 1, "Conventional Jet Fuels" (Seattle, WA: Boeing Corp., September 1990), pp. 46-50.

${ }^{171}$ R. Salthouse, Making Clean Gasoline (Logistics Management Institute, September 1992); and A.K. Rhodes, "U.S. Refiners Scramble to Meet Reformulated Gasoline Mandate," Oil and Gas Journal (January 27, 1992).

${ }^{172}$ The Energy Information Administration use standard factors to convert volumetric data on gasoline consumed to energy data on gasoline consumed. Because reformulated fuels contain about 1 percent less Btu per gallon than standard gasoline, this conversion factor somewhat overestimates reformulated gasoline consumption on an energy basis. The emissions coefficient presented here is designed to be used with EIA energy consumption data. In the absence of this anomaly, the per unit of energy produced emissions coefficient would be nearly unchanged from that of standard gasoline.
} 
In addition to updating the emissions coefficient for motor gasoline to reflect the introduction of reformulated fuels, this appendix includes updated emissions coefficients for jet fuel, crude oil, and LPG. Emissions coefficients for all fossil fuels are shown in Table B1.

\section{Motor Gasoline}

Almost 20 percent of all U.S. greenhouse gas emissions are attributable to motor gasoline consumption. As with all petroleum products, the emissions coefficient for motor gasoline is a function of its density and carbon content. This relationship is particularly clear in the case of motor gasoline, because the share of impurities found in the fuel must be kept very low to maintain the operating condition of modern automobile engines and limit the environmental impact of vehicle use.
Motor gasoline density varies between summer and winter grades and from low octane to high octane. This variation takes into account the differing performance requirements of gasoline associated with temperature changes. The density of gasoline has increased slowly over the past decade, across all octane grades and in all seasons. ${ }^{173}$ This trend is partially the result of the phase-out of leaded gasoline. In order to maintain the "anti-knock" quality and octane ratings of motor gasoline in the absence of lead, the portion of aromatic hydrocarbons used in gasoline must be increased. Aromatic hydrocarbons take the form of $\mathrm{C}_{\mathrm{n}} \mathrm{H}_{2 \mathrm{n}-2 \text {, a lower }}$ ratio of hydrogen to carbon than other hydrocarbons typically found in gasoline. Because carbon is much heavier than hydrogen, this lower ratio results in increased fuel density and higher shares of carbon. The result has been an emissions coefficient that rose slowly from 19.39 million metric tons carbon per quadrillion

Table B1. Carbon Emissions Coefficients at Full Combustion, 1985-1995 (Million Metric Tons of Carbon per Quadrillion Btu)

\begin{tabular}{|c|c|c|c|c|c|c|c|c|c|c|c|}
\hline Fuel & 1985 & 1986 & 1987 & 1988 & 1989 & 1990 & 1991 & 1992 & 1993 & 1994 & 1995 \\
\hline \multicolumn{12}{|l|}{ Petroleum } \\
\hline Motor Gasoline . & 19.37 & 19.38 & 19.38 & 19.39 & 19.41 & 19.41 & -19.41 & 19.42 & 19.43 & 19.45 & 19.38 \\
\hline LPG $\ldots \ldots \ldots \ldots \ldots$ & 16.98 & 17.03 & 17.05 & 17.04 & 17.07 & 17.00 & 16.99 & 17.00 & 16.98 & 17.02 & 17.01 \\
\hline Jet Fuel $\ldots \ldots \ldots \ldots \ldots \ldots$ & 19.43 & 19.42 & 19.42 & 19.42 & 19.41 & 19.40 & 19.40 & 19.39 & 19.37 & 19.35 & 19.34 \\
\hline Distillate Fuel $\ldots \ldots \ldots \ldots$ & 19.95 & 19.95 & 19.95 & 19.95 & 19.95 & 19.95 & 19.95 & 19.95 & 19.95 & 19.95 & 19.95 \\
\hline Residual Fuel ... & 21.49 & 21.49 & 21.49 & 21.49 & 21.49 & 21.49 & 21.49 & 21.49 & 21.49 & 21.49 & 21.49 \\
\hline Asphalt and Road Oil & 20.62 & 20.62 & 20.62 & 20.62 & 20.62 & 20.62 & 20.62 & 20.62 & 20.62 & 20.62 & 20.62 \\
\hline Lubricants $\ldots \ldots \ldots$ & 20.24 & 20.24 & 20.24 & 20.24 & 20.24 & 20.24 & 20.24 & 20.24 & 20.24 & 20.24 & 20.24 \\
\hline Petrochemical Feed . . . . . . & 19.37 & 19.37 & 19.37 & 19.37 & 19.37 & 19.37 & 19.37 & 19.37 & 19.37 & 19.37 & 19.37 \\
\hline Aviation Gas $\ldots \ldots \ldots \ldots$ & 18.87 & 18.87 & 18.87 & 18.87 & 18.87 & 18.87 & 18.87 & 18.87 & 18.87 & 18.87 & 18.87 \\
\hline Kerosene ........ & 19.72 & 19.72 & 19.72 & 19.72 & 19.72 & 19.72 & 19.72 & 19.72 & 19.72 & 19.72 & 19.72 \\
\hline Petroleum Coke ......... & 27.85 & 27.85 & 27.85 & 27.85 & 27.85 & 27.85 & 27.85 & 27.85 & 27.85 & 27.85 & 27.85 \\
\hline Special Naphtha . . . . . . . . & 19.86 & 19.86 & 19.86 & 19.86 & 19.86 & 19.86 & 19.86 & 19.86 & 19.86 & 19.86 & 19.86 \\
\hline Waxes and Miscellaneous .... & 19.81 & 19.81 & 19.81 & 19.81 & 19.81 & 19.81 & 19.81 & 19.81 & 19.81 & 19.81 & 19.81 \\
\hline Industrial Sector "Other"a $\ldots$ & 20.19 & 20.03 & 20.06 & 20.04 & 19.93 & 19.99 & 20.16 & 20.19 & 20.24 & 20.24 & 20.31 \\
\hline \multicolumn{12}{|l|}{ Coal } \\
\hline Residential/Commercial . & 25.89 & 25.88 & 25.90 & 25.87 & 25.94 & 25.92 & 26.00 & 26.13 & 25.97 & 25.95 & 25.95 \\
\hline Industrial Coking . .... & 25.43 & 25.41 & 25.39 & 25.40 & 25.40 & 25.51 & 25.51 & 25.51 & 25.51 & 25.52 & 25.52 \\
\hline Other Industrial . . . & 25.53 & 25.55 & 25.53 & 25.53 & 25.56 & 25.58 & 25.60 & 25.62 & 25.61 & 25.63 & 25.63 \\
\hline Electric Utility & 25.64 & 25.63 & 25.64 & 25.67 & 25.67 & 25.68 & 25.69 & 25.69 & 25.71 & 25.72 & 25.72 \\
\hline Flare Gas . . . . . . . . & 14.92 & 14.92 & 14.92 & 14.92 & 14.92 & 14.92 & 14.92 & 14.92 & 14.92 & 14.92 & 14.92 \\
\hline Natural Gas $\ldots \ldots \ldots \ldots \ldots$ & 14.47 & 14.47 & 14.47 & 14.47 & 14.47 & 14.47 & 14.47 & 14.47 & 14.47 & 14.47 & 14.47 \\
\hline Crude Oil . . . . . . . . . . . & 20.11 & 20.12 & 20.13 & 20.16 & 20.13 & 20.16 & 20.18 & 20.22 & 20.23 & 20.21 & 20.23 \\
\hline
\end{tabular}

${ }^{a}$ Composite coefficient based on final calculations, accounting for fraction not combusted and deductions for nonfuel use, using unpublished disaggregated energy data.

Source: Energy Information Administration, Emissions of Greenhouse Gases in the United States 1987-1994, DOE/EIA-0573(87-94) (Washington, DC, October 1995), pp. 78-92, and estimates presented in this appendix.

\footnotetext{
${ }^{173}$ National Institute of Petroleum and Energy Research, Motor Gasoline, Summer, and Motor Gasoline, Winter (1984-1994).
} 
Btu in 1988 to 19.45 million metric tons carbon per quadrillion Btu in 1994. Table B2 shows the increasing densities and emission coefficients for that time period.

The trend toward higher emissions coefficients ended in 1995. That year, reformulated gasoline was consumed in large volumes (about 25 percent of overall gasoline consumption) for the first time. The density of reformulated gasoline is about 1 percent less than that of standard gasoline, and the much lower carbon contents of the principal additives to reformulated gasoline (Table B3) reduce the overall share of carbon in reformulated fuel. Thus, after accounting for the 25 percent of fuel consumed with a lower emissions profile, the emissions coefficient for motor gasoline dropped from 19.45 million metric tons per quadrillion Btu in 1994 to 19.39 million metric tons per quadrillion Btu in 1995.

From 1995 on, the use of reformulated gasoline in areas with serious ambient air pollution is mandated by the Clean Air Act Amendments of 1990. The three principal additives to reformulated gasoline are MTBE, ETBE, and TAME. These additives differ from the hydrocarbons typically found in motor gasoline due to the presence of an oxygen atom in their molecules. The oxygen atoms reduce the emissions of carbon monoxide and unburned hydrocarbons. In contrast to standard motor gasoline, which has an estimated carbon share of 86.6 percent, these additives have a carbon share of 68.2 to 70.5 percent. ${ }^{174}$ MTBE is the most important additive, representing about 10 percent of reformulated gasoline in 1995. It has a density of 59.1 degrees API and a carbon content of 68.2 percent.

To derive an overall emissions coefficient for gasoline consumed during 1995, individual coefficients for motor gasoline consumed in the winter and summer months were developed. These coefficients were based on the densities of product samples collected by the National Institute on Petroleum and Energy Research (NIPER) used in conjunction with a carbon share of 86.6 percent. $^{175}$

Emissions coefficients for reformulated fuels consumed during the summer and winter were calculated using the following procedure. First, the carbon share of each additive used in reformulated gasoline was calculated from its chemical formula and combined with the additive's density and energy content as provided by the

Table B2. Changes in Motor Gasoline Density, 1988-1995 (Degrees API)

\begin{tabular}{|c|c|c|c|c|c|c|c|c|}
\hline Fuel Grade & 1988 & 1989 & 1990 & 1991 & 1992 & 1993 & 1994 & 1995 \\
\hline \multicolumn{9}{|l|}{ Winter Grade } \\
\hline Low Octane & 62.2 & 62.0 & 62.0 & 61.8 & 61.4 & 61.0 & 60.1 & P59.4 \\
\hline Mid Octane & NA & 59.9 & 60.8 & 60.4 & 60.2 & 59.9 & 59.4 & P58.8 \\
\hline High Octane & 59.6 & 58.8 & 59.0 & 59.3 & 59.0 & 58.7 & 58.5 & P58.2 \\
\hline \multicolumn{9}{|l|}{ Summer Grade } \\
\hline Low Octane & 58.9 & 58.2 & 58.2 & 58.0 & 57.4 & 56.1 & 55.7 & 56.1 \\
\hline Mid Octane & NA & 57.1 & 57.4 & 57.1 & 56.4 & 55.5 & 54.8 & 55.6 \\
\hline High Octane . . . . . . . . . & 56.8 & 55.3 & 55.5 & 55.7 & 55.6 & 54.4 & 53.8 & 55.1 \\
\hline $\begin{array}{l}\text { Average Emissions Coefficient } \\
\text { (Million Metric Tons Carbon } \\
\text { per Quadrillion Btu) . . . . . . }\end{array}$ & 19.39 & 19.41 & 19.41 & 19.41 & 19.42 & 19.43 & 19.45 & aP19.38 \\
\hline
\end{tabular}

${ }^{a}$ Emissions coefficient weighted for reformulated gasoline, which has a lower density than standard gasoline.

NA = not applicable. $P=$ preliminary data.

Sources: National Institute of Petroleum and Energy Research, Motor Gasoline, Summer, and Motor Gasoline, Winter (19841994). M. DeLuchi, Emissions of Greenhouse Gases from the Use of Transportation Fuels and Electricity, Vol. 2, Appendices A-S, ANL/ESD/TM-22 (Chicago, IL: Argonne National Laboratory, November 1993), p. c-6. Properties of reformulated fuels from California Air Resources Board.

\footnotetext{
${ }^{174} \mathrm{M}$. DeLuchi, Emissions of Greenhouse Gases from the Use of Transportation Fuels and Electricity, Volume 2, Appendices A-S, ANL/ESD/TM-22 (Chicago, IL: Argonne National Laboratory, November 1993), p. c-6. Properties of reformulated fuels from California Air Resources Board.

${ }^{175}$ National Institute of Petroleum and Energy Research, Motor Gasoline, Summer (1995), and Motor Gasoline, Winter (1994-1995; M. DeLuchi, Emissions of Greenhouse Gases from the Use of Transportation Fuels and Electricity, Volume 2, Appendices A-S, ANL/ESD/TM-22 (Chicago, IL: Argonne National Laboratory, November 1993), p. c-6.
} 
Table B3. Characteristics of Major Reformulated Fuel Additives

\begin{tabular}{c|c|c|c}
\hline Additive & $\begin{array}{c}\text { Density } \\
\text { (Degrees API) }\end{array}$ & $\begin{array}{c}\text { Carbon Share } \\
\text { (Percent) }\end{array}$ & $\begin{array}{c}\text { Emissions Factor } \\
\text { (Million Metric Tons per Quadrillion Btu) }\end{array}$ \\
\hline MTBE $\ldots \ldots \ldots \ldots \ldots \ldots$ & 59.1 & 68.2 & 16.92 \\
ETBE $\ldots \ldots \ldots \ldots \ldots \ldots$ & 59.1 & 70.5 & 17.07 \\
TAME $\ldots \ldots \ldots \ldots \ldots$ & 52.8 & 70.5 & 17.00 \\
\hline
\end{tabular}

Sources: California Air Resources Board, and estimates developed for this report.

California Air Resources Board to produce individual coefficients for each fuel additive. Next, the reformulated fuel was separated into its standard fuel components and its additive portions based on fuel samples examined by NIPER. ${ }^{176}$ The additive portions were defined as the net increase in MTBE, ETBE, or TAME compared with standard fuel, since small amounts of these compounds are present in standard gasoline. The emissions coefficients for standard gasoline and for each of the additives were then weighted by their proportion in reformulated fuel to arrive at a coefficient for reformulated fuel in each season.

After developing independent coefficients for both standard and reformulated fuel, each season's coefficients were combined by weighting according to the ratio of standard versus reformulated consumption (approximately three to one). The combined summer and winter coefficients were then weighted on the basis of seasonal consumption, with just over half occurring in summer, to derive an overall emissions coefficient for motor gasoline. This overall emissions coefficient may be revised, because data on the average composition of fuel used during October, November, and December 1995 are not yet available, and thus the winter coefficient for 1995 is based on data for January through March only.

\section{Jet Fuel}

The EIA classifies jet fuel into two categories: "naphthabased" and "kerosene-based" jet fuel. Kerosene-based jet fuel includes civil-grade Jet $A$, consumed in commercial jet airliners. It is an important contributor to U.S. greenhouse gas emissions, accounting for about 4 percent of U.S. carbon dioxide emissions. Naphthabased jet fuels were used primarily by the military until 1993, when the Defense Department began a conversion from naphtha-based JP-4 jet fuel to kerosene-based JP-8 jet fuel. This conversion has resulted in the share of naphtha-based jet fuel used in the United States declining from 12 percent of U.S. jet fuel consumption in 1991 to 7.2 percent in 1993 and further to 1 percent in $1995 .{ }^{177}$ The annual emissions coefficients for jet fuel represent a consumption-weighted average of the coefficient for kerosene-based jet fuel and the coefficient for naphtha-based jet fuel (Table B4). Because the emissions coefficient for naphtha-based jet fuel is about 3 percent higher than the coefficient for kerosene-based jet fuel, the near elimination of naphtha-based fuels from the marketplace has led to a steadily declining emissions coefficient for jet fuel.

The emissions coefficient for kerosene-based jet fuel was developed by using data from 39 samples of Jet $A$ collected and analyzed by Boeing. ${ }^{178}$ The average density of these samples is 44.5 degrees API gravity, and the average carbon share is 85.8 percent. The resulting emissions coefficient is 19.33 million metric tons per quadrillion Btu. The emissions coefficient for naphtha-based jet fuel is based on less empirical data and has a larger margin of error than that for kerosenebased fuel. However, the small share of jet fuel consumed that is naphtha-based limits the effect of this error on the overall uncertainty of a weighted jet fuel coefficient. According to ASTM standards, naphthabased jet fuel has a density between 45 and 57 degrees API gravity. ${ }^{179}$ To develop an emissions coefficient, a density of 49 degrees API is assumed. A carbon content of 85.8 percent is assumed, based on an estimated sulfur content of 0.1 percent and a hydrogen content of

\footnotetext{
${ }^{176}$ National Institute of Petroleum and Energy Research, Motor Gasoline, Summer (1995), and Motor Gasoline, Winter (1994-1995).

${ }^{177}$ Energy Information Administration, Annual Energy Review, DOE/EIA-0384 (Washington, DC, various years).

${ }^{178}$ O.J. Hadaller and A.M. Momenthy, The Characteristics of Future Fuels, Part 1, "Conventional Jet Fuels" (Seattle, WA: Boeing Corp., September 1990), pp. 46-50.

${ }^{179}$ American Society for Testing and Materials, ASTM and Other Specifications for Petroleum Products and Lubricants (Philadelphia, PA, 1985), p. 60.
} 
Table B4. Consumption-Weighted Emissions Coefficients for Jet Fuel, 1988-1995

(Million Metric Tons Carbon)

\begin{tabular}{c|r|r|r|r|r|r|r|r}
\hline Data Element & 1988 & 1989 & 1990 & 1991 & 1992 & 1993 & 1994 & 1995 \\
\hline Share of Naphtha-Based Jet Fuel (Percent) $\ldots$ & 13.9 & 13.1 & 11.4 & 12.0 & 9.4 & 7.2 & 2.9 & 1.0 \\
Share of Kerosene-Based Jet Fuel (Percent) $\ldots$ & 86.1 & 86.9 & 88.6 & 88.0 & 90.6 & 92.9 & 97.1 & 99.0 \\
Weighted Emissions Coefficient .......... & 19.42 & 19.41 & 19.40 & 19.40 & 19.39 & 19.37 & 19.35 & 19.34 \\
\hline
\end{tabular}

Sources: Energy Information Administration, Annual Energy Review, DOE/EIA-0384 (Washington, DC, various years). O.J. Hadaller and A.M. Momenthy, The Characteristics of Future Fuels, Part 1, "Conventional Jet Fuels" (Seattle, WA: Boeing Corp., September 1990), pp. 46-50. C.R. Martel and L.C. Angello, "Hydrogen Content as a Measure of the Combustion Performance of Hydrocarbon Fuels," in Current Research in Petroleum Fuels, Vol. I (New York, NY: MSS Information Corporation, 1977), p. 116.

14.1 percent. ${ }^{180}$ These inputs produce an emissions coefficient for naphtha-based jet fuel of 19.95 million metric tons carbon per quadrillion Btu.

\section{Crude Oil}

Crude oil composition is highly heterogeneous; however, the share of carbon in a fixed amount of crude oil (e.g, a gallon or barrel) varies systematically with such commonly available identifying characteristics as density and sulfur content. Because the economic value of a barrel of crude oil is largely a product of the oil's density and sulfur content, these values are regularly recorded. Further, the ELA maintains detailed data on the average density and sulfur content of crude oil entering U.S. refineries. ${ }^{181}$ Thus, the annual emissions coefficient for crude oil is pegged to these two variables.

In the November 1994 edition of Emissions of Greenhouse Gases in the United States, Appendix A describes the methods used to derive a relationship between crude oil density, sulfur content, and the percentage of carbon in crude oil. ${ }^{182}$ Using ultimate analyses of 182 crude oil samples, the sulfur content and density of the samples was related to their carbon content. Regression analysis produced the following equation, which is used to estimate the carbon content of crude oil:

$$
\begin{aligned}
\text { Percent Carbon }= & 76.99+(10.19 \times \text { Specific Gravity }) \\
& +(-0.76 \times \text { Sulfur Content }) .
\end{aligned}
$$

Annualized emissions coefficients are developed by inserting the average density and sulfur content for crude oil entering U.S. refineries for each year from 1985 through 1995 to provide the share of carbon in an average barrel of oil during each year. After the share of carbon is derived, it is used in conjunction with fuel density to estimate the total mass of carbon in a barrel of crude oil. An emissions coefficient per unit of energy is then calculated, using EIA's standard energy content for crude oil of 5.8 million Btu per barrel.

The 1995 emissions coefficient for crude oil is 20.22 million metric tons carbon per quadrillion Btu, a slight increase over the 1994 value. The increase can be traced to a small rise in the density of crude oil and a small reduction in sulfur content, which increased the share of carbon in crude oil from 84.97 percent to 84.99 percent (Table B5).

\section{Liquefied Petroleum Gases}

The ELA identifies four categories of paraffinic hydrocarbons $^{183}$ as liquefied petroleum gases (LPG): ethane, propane, isobutane, and $n$-butane. Because each of these hydrocarbons is a pure paraffinic compound, their carbon shares are easily derived by taking into account the atomic weight of carbon (12) and the atomic weight of hydrogen (1). Thus, for example, the carbon share of ethane, $\mathrm{C}_{2} \mathrm{H}_{6}$, which has an atomic weight of 30 , is 80 percent. The densities for these compounds are also well known, allowing emissions coefficients to be calculated easily.

\footnotetext{
${ }^{180} \mathrm{C}$. R. Martel and L.C. Angello, "Hydrogen Content as a Measure of the Combustion Performance of Hydrocarbon Fuels," in Current Research in Petroleum Fuels, Volume I (New York, NY: MSS Information Corporation, 1977), p. 116.

${ }^{181}$ Energy Information Administration, Petroleum Supply Annual, DOE/EIA-0340 (Washington, DC, various years).

${ }^{182}$ Energy Information Administration, Emissions of Greenhouse Gases in the United States 1987-1992, DOE/EIA-0573 (Washington, DC, November 1994), pp. 73-92.

${ }^{183}$ The chemical formula of a paraffinic hydrocarbon takes the form $\mathrm{C}_{n} \mathrm{H}_{2 n+2 n}$.
} 
Table B5. U.S. Crude Oil Characteristics, 1988-1995

\begin{tabular}{|c|c|c|c|c|c|c|c|c|}
\hline Characteristic & 1988 & 1989 & 1990 & 1991 & 1992 & 1993 & 1994 & 1995 \\
\hline Density (API Gravity). & 31.93 & 32.14 & 31.86 & 31.64 & 31.32 & 31.30 & 31.39 & 31.30 \\
\hline Density (Specific Gravity) & 0.8657 & 0.8646 & 0.8662 & 0.8674 & 0.8691 & 0.8692 & 0.8686 & 0.8692 \\
\hline Sulfur Content (Percent) . & 1.04 & 1.06 & 1.10 & 1.13 & 1.16 & 1.15 & 1.14 & 1.13 \\
\hline Carbon Share (Percent) & 85.02 & 84.99 & 84.98 & 84.97 & 84.96 & 84.97 & 84.97 & 84.99 \\
\hline $\begin{array}{l}\text { Emissions Coefficient } \\
\text { (Million Metric Tons Carbon } \\
\text { per Quadrillion Btu) ....... }\end{array}$ & 20.16 & 20.13 & 20.16 & 20.18 & 20.22 & 20.22 & 20.21 & 20.22 \\
\hline
\end{tabular}

Note: Emissions coefficients assume 100 percent combustion.

Sources: Energy Information Administration, Petroleum Supply Annual, DOE/EIA-0340 (Washington, DC, various years). Energy Information Administration, Emissions of Greenhouse Gases in the United States 1987-1992, DOE/EIA-0573 (Washington, DC, November 1994), p. 91.

The EIA collects data on consumption of each of these compounds and then reports them as LPG in the Petroleum Supply Annual. ${ }^{184}$ By weighting each compound's individual emissions coefficient by its share of energy consumed, an overall emissions coefficient for LPG is derived. The results of this procedure are shown in Table B6. As the table illustrates, the emissions coefficient is dominated by propane, which has represented about three-fifths of LPG consumption between 1988 and 1995. The overall emissions coefficient has moved in a range smaller than \pm 0.2 percent in that time frame, with nearly all variation the result of changes in the ratio between consumption of higher hydrocarbons isobutane and $n$-butane, and the shorter chain compound ethane.

Table B6. Consumption Shares for Liquid Petroleum Gases by Energy Content, 1988-1995 (Percent)

\begin{tabular}{|c|c|c|c|c|c|c|c|c|}
\hline Fuel $^{\mathrm{a}}$ & 1988 & 1989 & $1990^{\circ}$ & 1991 & 1992 & 1993 & 1994 & 1995 \\
\hline Ethane & 25.5 & 22.4 & 26.8 & 27.6 & 26.7 & 28.1 & 25.9 & 26.7 \\
\hline Propane & 59.2 & 62.5 & 63.2 & 62.5 & 63.1 & 62.5 & 61.5 & 61.7 \\
\hline Isobutane .............. & 3.5 & 1.7 & 1.4 & 2.4 & 2.4 & 3.3 & 4.4 & 4.2 \\
\hline$n$-Butane $\ldots \ldots \ldots \ldots \ldots \ldots$ & 11.8 & 13.5 & 8.6 & 7.5 & 7.8 & 6.0 & 8.2 & 7.5 \\
\hline $\begin{array}{l}\text { Overall Emissions Coefficient } \\
\text { (Million Metric Tons Carbon } \\
\text { per Quadrillion Btu) } \ldots \ldots \ldots \ldots \ldots\end{array}$ & 17.04 & 17.07 & 17.00 & 16.99 & 17.00 & 16.98 & 17.02 & 17.01 \\
\hline
\end{tabular}

${ }^{a}$ Emissions coefficients for the individual fuels are 16.25 (ethane), 17.20 (propane), 17.75 (isobutane), and 17.72 ( $n$-butane). Note: Emissions coefficients assume 100 percent combustion.

Sources: Energy Information Administration, Petroleum Supply Annual, DOE/EIA-0340 (Washington, DC, various years). V.B. Guthrie (ed.), Petroleum Products Handbook (New York, NY: McGraw Hill, 1960), p. 3-3.

\footnotetext{
${ }^{184}$ Energy Information Administration, Petroleum Supply Annual, DOE/EIA-0340 (Washington, DC, various years), Table 17.
} 


\section{Appendix C Uncertainty in Emissions Estimates}

\section{Overview}

Emissions estimates in this report are generated largely by multiplying some activity factor, such as coal or natural gas consumption, by an emissions coefficient. The reliability of both the activity data and the emissions coefficients used in this report varies widely. This Appendix discusses the uncertainties associated with the estimates and extrapolations presented in the report.

The uncertainties in emissions estimates come from collecting data from a limited number of sources. The data are weighted or extrapolated to obtain national estimates for similar sources in each category or industry. This estimation approach is a method to scale up the average emissions from a source, determined by a limited sample, to represent the population of emissions from each category or fuel. This method uses the concepts of emissions coefficient and activity factor for each category. For each category or fuel type:

$$
\begin{gathered}
\text { Emissions Coefficient } \times \text { Activity Factor }= \\
\text { National Emissions for a Category . }
\end{gathered}
$$

Since each factor contains both bias and sampling errors, the estimate of the national emissions for a category is:

$$
\begin{aligned}
& (E C+\text { Bias }+ \text { Sampling Error }) \times \\
& \qquad(A F+\text { Bias }+ \text { Sampling Error })
\end{aligned}
$$

where $E C$ is the emissions coefficient and $A F$ is the activity factor. Bias is a systematic non-random error which, in this case, is usually imbedded in the $A F$ term and due to systematic imperfections in the data collection process, whereas the random sampling error is generally attributed to small sample size, measurement and reporting errors, and timing problems.

In general, estimates of carbon dioxide emissions are more reliable than estimates for other gases. While this report does not explicitly calculate uncertainty ranges, it is likely that the estimate of carbon dioxide emissions is accurate to within 10 percent, implying an emissions range from 1.3 billion to 1.6 billion metric tons. To the extent that the activity factor is somewhat understated within the point estimate, the actual (unobservable) value is likely to be somewhat higher, because this report cannot capture all emissions sources.

Estimates of methane emissions are much more uncertain. The level of precision is probably on the order of 30 to 50 percent. Estimates of methane emissions are also likely to understate actual emissions, as a result of the exclusion of sources that are unknown or difficult to quantify.

Nitrous oxide emissions estimates are by far the most unreliable. Estimates of emissions from nitrogenous fertilizers are only accurate to an order of magnitude, making them either the largest source of nitrous oxide emissions or, alternatively, an insignificant source. Coefficients for nitrous oxide emissions from fossil fuel combustion are not available for all sources and, where available, may be unreliable. Additionally, several known sources of nitrous oxide are not measured and therefore are excluded from estimated totals.

\section{Carbon Dioxide}

\section{Sources of Uncertainty}

Most carbon dioxide emissions estimated in this report are the result of the combustion of fossil fuels. The uncertainties in estimates of emissions from fossil fuel combustion can be divided into four types:

- Uncertainties in the volumes of fuel consumed. In general, volumetric fuel data are believed to be fairly reliable, plus or minus about 3 to 5 percent; estimates of total consumption by fuel are more reliable than estimates by sector, or by particular product.

- Uncertainties in the characteristics of fuel consumed. Fuel data are collected on a volume or weight basis, but the density and energy content of fuels must often be estimated. The energy content of natural gas is reliable to 0.5 percent, but the reliability of energy content estimates for coal and petroleum products is lower.

- Uncertainties in the emissions coefficients. Emissions coefficients can be computed with a high 
degree of precision for a particular fuel sample, based on a laboratory analysis. However, due to characteristics of a fuel that are difficult to measure accurately, the emissions coefficient for the sample fuel may not match the actual characteristics of fuels consumed. The pipeline-quality natural gas coefficient is probably accurate to within 1 percent, but the reliability of the coal and petroleum product coefficients is lower, because they are more heterogeneous.

- Uncertainties of coverage, due to excluded or unknown sources of emissions.

\section{Fuel Consumption}

In general, EIA energy statistics are most accurate where the energy industry is highly concentrated and/or heavily regulated, and least accurate where activities are decentralized, with large numbers of producers or consumers, or the fuel exists in many heterogeneous states.

While it is impossible to be certain about the absolute magnitude and distribution by type of error in the energy data, it is unlikely that most of the error is "bias error" rather than random "sampling error." The EIA collects the same data from mostly the same respondents every year (although survey frames are systematically updated), using mostly the same methods. Product flows that escape the coverage of the statistical system are likely to stay outside the statistical system from one year to the next. Similarly, if respondents make undetected definitional or computational errors (for example, misclassifying a petroleum product), they are likely to repeat their mistake for prolonged periods.

There is indirect evidence in favor of the relative unimportance of random error in energy statistics, in the form of the relative lack of variability of these statistics compared with other economic time series. That most EIA surveys are censuses, with what is intended to be 100 percent coverage of eligible respondents, rather than small sample surveys, reduces the scope for random errors.

If, as we suspect, random error is relatively unimportant, then most of the error is bias error, made in essentially the same way every year. This implies that while the level of U.S. emissions of carbon dioxide could be systematically lower or higher than reported here, the reported trends over time are more reliable than the uncertainties in the energy data would suggest.
Since energy production and consumption are covered by multiple surveys, it is possible to use this information to gain insight into the possible uncertainties in the energy data.

Coal. Coal production and consumption data are based on weight-short tons of coal. Coal consumption by regulated electric utilities, including both tonnage and energy content, is universally reported to the EIA and the Federal Energy Regulatory Commission (FERC). In 1994 utility coal consumption accounted for about 88 percent of U.S. coal consumption. There are likely to be only minor errors (around 1 percent) in reported utility coal consumption. Industrial, residential, and commercial coal consumption estimates are subject to potentially larger errors, especially in the counting of residential and commercial sector consumption.

The statistical discrepancy for coal production (the difference between reported consumption and reported production less exports, plus imports, plus stock changes) was on the order of 5 million short tons, or about 0.6 percent of consumption, in 1994.

Natural Gas. Most natural gas is sold or transported by State-regulated local distribution companies. Excluding imports, the statistical discrepancy for natural gas has an average value of between 2 and 3 percent of consumption, with reported consumption usually smaller than reported production. This may imply some systematic source of underreporting of consumption.

Inaccuracies in natural gas volumetric data come from inherent limitations in the accuracy of natural gas metering, as well as the usual problems of misreporting and timing differences. For example, natural gas consumption by electric utilities, as reported by the utilities, averaged about a 0.7-percent difference from natural gas consumption as reported by natural gas sellers in $1994 .{ }^{185}$

Petroleum. U.S. petroleum consumption was estimated on the basis of "petroleum products supplied," which means the volume of petroleum products shipped from primary storage facilities. Since there are only about 200 oil refineries in the United States, coverage of crude oil inputs and refinery outputs is generally complete.

The EIA requires a detailed breakdown and accounting of petroleum products produced by refineries, including refinery fuel. There are several reporting anomalies in EIA petroleum data:

\footnotetext{
${ }^{185}$ Energy Information Administration, Natural Gas Annual 1994, DOE/EIA-0131(94) (Washington, DC, November 1995), p. 231.
} 
- Each year more crude oil is supplied to refineries than can be accounted for by oil production, imports, and stock changes. This "unaccounted for crude oil" averaged 193,000 barrels per day, or approximately 1.4 percent of refinery supply in $1995^{186}$

- Every year, 80,000 to 150,000 barrels per day more "unfinished oils" reach refineries than can be accounted for by sales and imports of unfinished oils, ${ }^{187}$ This is about 1.1 percent of refinery runs and 0.9 percent of oil consumption. In 1995, there was on the average 151,000 barrels per day of unaccounted for unfinished oils.

- By definition, the source of "unaccounted for" crude oil is unknown. It is likely due to imprecisions in recorded crude oil production, import, and stock change data. In EIA's State Energy Data Report, which presents consumption estimates, unaccounted for crude oil is included in consumption.

The unfinished oil discrepancy is probably due to the asymmetric treatment of interrefiner sales of unfinished oils. To the buyer, who knows the intended use of the product, it is motor gasoline or distillate fuel. To the seller, it is an unfinished oil. In the State Energy Data Report, the unfinished oil discrepancy is accounted for through an adjustment to "other oils." However, the implication is that total oil consumption figures are more reliable than the exact distribution of consumption across specific petroleum products. Overall, it is likely that petroleum consumption estimates are accurate to within 5 percent.

Nonfuel Use. Data for nonfuel use of petroleum products are more uncertain than those for total use of petroleum products. There are two main methods of estimating nonfuel use:

- Specialized petroleum products, such as petrochemical feedstocks, waxes and polishes, asphalt, and lubricants, are assumed to be dedicated to nonfuel use.

- Nonfuel use of conventional fuels is estimated on the basis of survey results from EIA's Manufacturing Energy Consumption Survey (MECS), with additional detail from trade association data and from known specific nonfuel uses (such as fertilizer feedstocks for natural gas). ${ }^{188}$ However, MECS is a sample survey conducted only at 3-year intervals, with the sample optimized to detect the use of fuels for heat and power. Using MECS to measure nonfuel use requires interpolating between sample years and correcting for certain sampling problems associated with reported nonfuel use.

The main uncertainty in estimating carbon sequestered from nonfuel use is not the amount of product used, but the fate of its carbon. The sequestration percentages used in this report are estimates, originally based on the typical fate of a particular class of products. The actual distribution of nonfuel uses of products is not always known with precision and could vary considerably from the "typical" usage. However, since sequestration through nonfuel use corresponds to only about 5 percent of total emissions, even large variations in the amount sequestered would have a small effect on estimated total emissions.

\section{Conversion Factors}

EIA oil and gas data are collected in volumetric units: barrels of oil and billion cubic feet of gas. Carbon emissions factors for fossil fuels usually take the form of tons of carbon per unit of energy content. Emissions factors are computed by dividing the carbon content (by weight) of a particular fuel by its energy content. Thus, in order to match an emissions factor to a fuel accurately, it is necessary to know its energy content with precision; and in the case of fuel quantity based on volumetric data, it is also necessary to know the density of the fuel.

Each step that transforms the data from native units into more useful units inevitably reduces the precision of the resulting data, because the conversion factors are themselves statistical estimates or extrapolations, which may not precisely match the actual composition of the fuel.

Coal. Coal data are collected by State, coal rank, and weight (short tons). Electric utilities are asked to report both the rank and the energy content of the coal they burn. Since, in principle, utilities need to know the energy content of the fuels they purchase with precision, the energy content data should be fairly accurate. On the other hand, there is considerably more uncertainty in the rank or energy content of coal distributed outside the utility sector, which in 1994 accounted for about 12 percent of U.S. coal consumption.

The quality of coal can vary considerably within States and within a particular rank. Lignite, for example, is

\footnotetext{
${ }^{186}$ Energy Information Administration, Petroleum Supply Annual 1995, DOE/ELA-0340(95)/1 (Washington, DC, May 1996), p. 6.

${ }^{187}$ Energy Information Administration, Petroleum Supply Annual 1995, DOE/EIA-0340(95)/1 (Washington, DC, May 1996$)$, p. 35.

${ }^{188}$ Energy Information Administration, Manufacturing Consumption of Energy 1991, DOE/EIA-0512(91) (Washington, DC, December 1994).
} 
defined as containing 6,300 to 8,300 Btu per pound, a range of about 15 percent. Subbituminous coal, by definition, has a range of 8,300 to 11,500 Btu per pound. ${ }^{189}$ Thus, due to the ranking of the heat content, there may be errors of up to 15 percent in the industrial and residential/commercial coal conversion factors. Residential/commercial and industrial coal consumption accounts for only about 5 percent of total U.S. energy-related carbon emissions. Hence, even large errors would have only a small impact on the ultimate estimates.

Natural Gas. The composition of natural gas also varies considerably. In a recent survey of several thousand gas samples taken from local distribution companies around the United States, the Btu content ranged from 970 to 1,208 Btu per thousand cubic feet. ${ }^{190}$ However, 80 percent of the samples fell within a much narrower range of 1,006 to 1,048 Btu per thousand cubic feet. Further, the average and median values of the samples fell within 0.3 percent of the national-level figure as reported in EIA's Natural Gas Annual. This comparison suggests that EIA data on the energy content of natural gas are accurate to within 0.5 percent. This is not surprising, because local distribution companies monitor the energy content of natural gas to ensure adherence to contractual specifications, and they report the average energy content to the EIA.

Petroleum. The energy content of petroleum products varies more by volume than by weight. The density and the energy content of petroleum products are rarely measured by producers or consumers, and hence they are frequently not known with precision. Electric utilities measure the energy content of the residual oil they burn and report it to the EIA. Liquid petroleum gases (propane, butane, and ethane) are pure compounds, and their energy content can be computed directly.

Liquid transportation fuels (jet kerosene, gasoline, and diesel fuel) are complex mixtures of many compounds, whose physical properties can vary considerably. Their energy content is not measured by consumers nor directly defined by product specifications. The EIA estimates the energy content of these fuels on the basis of standard or "typical" values for each product. The standard energy contents for motor gasoline and kerosene-based jet fuel are drawn from a 1968 report produced by the Texas Eastern Transmission Corporation. ${ }^{191}$ The energy content of distillate fuel oil is drawn from a Bureau of Mines Standard adopted in January $1950 .{ }^{192}$ Jet fuel and diesel samples obtained for this report showed an average energy content that differs from EIA estimates by about 2 percent. Samples of motor gasoline analyzed by the National Institute of Petroleum and Energy Research displayed an average energy content that differs from EIA estimates by less than 0.5 percent. Reformulated gasoline, with the additives MTBE, ETBE, and TAME typically representing about 10 percent of its volume, can be expected to have an energy content about 1 percent lower than standard gasoline. However, when collecting and disseminating motor gasoline data in units of energy, the EIA does not use a distinct conversion factor for reformulated gasoline.

\section{Carbon Emissions Coefficients}

Carbon emissions coefficients are calculated by dividing the carbon content of a particular fuel (for example, 0.85 metric tons of carbon per metric ton of fuel) by the energy content of that fuel (say, 43 million Btu per metric ton), producing an emissions coefficient (in this example, 19.8 million metric tons of carbon per quadrillion Btu). Both the energy content and the carbon content of the fuel are subject to a degree of uncertainty. The carbon content of fuels has only an indirect and general bearing on their economic value and consequently is not necessarily collected by fuel producers or consumers. While coefficients for coal and natural gas rely on analyses of a large set of fuel samples, coefficients for several petroleum products are based on "typical" or "representative" values, which may or may not perfectly reflect the underlying composition of the fuel. Variation in carbon content is limited to plus or minus 5 percent by the standard ratios of carbon to hydrogen in the hydrocarbon compounds that compose petroleum. ${ }^{193}$

Coal. There are large variations in the carbon and energy content of coals in different parts of the United States. Lignite may have as little as 12.6 million Btu per ton and contain 36 percent carbon, while anthracite

\footnotetext{
${ }^{189}$ Energy Information Administration, Coal Industry Annual 1993, DOE/EIA-0584(93) (Washington, DC, December 1994), pp. 262 and 266.

${ }^{190}$ W.E. Liss et al., Variability of Natural Gas Composition in Select Major Metropolitan Areas of the United States (Chicago, IL: Gas Research Institute, March 1992), p. 14.

${ }^{191}$ Energy Information Administration, State Energy Data Report 1993, DOE/EIA-0214(93) (Washington, DC, July 1995).

${ }^{192}$ Energy Information Administration, Annual Energy Review 1993, DOE/EIA-0384(93) (Washington, DC, July 1994), pp. 348-353.

${ }^{193}$ Energy Information Administration, Emissions of Greenhouse Gases in the United States 1987-1992, DOE/EIA-0573 (Washington, DC, November 1994), pp. 78-80.
} 
may have as much as 98 percent carbon and an energy content as high as 27 million Btu per ton. ${ }^{194}$

The carbon and heating values of coal are, in general, controlled by two factors:

- The ratio of flammable materials (carbon, hydrogen, and sulfur) in coal to nonflammable impurities (ash, etc.)

- The ratio of carbon to hydrogen and sulfur within the flammable portion of the coal.

Most of the gross variation in both energy and carbon content (for example, between lignite and anthracite) is due to variations in nonflammable impurities. Consequently, if the Btu content of coal is estimated accurately, most of the variation in the carbon content is removed.

There is, however, residual uncertainty about the ratio of carbon to hydrogen and sulfur in particular coals. The carbon content of any particular coal sample can be determined by chemical analysis, but characterizing the average carbon content of national coal production creates some uncertainty. For this report, the EIA relied on chemical analyses of several thousand coal samples, sorted by State of origin and coal rank, to compute national weighted average emissions coefficients (in million metric tons of carbon per million Btu) for each coal rank.

Natural Gas. Natural gas also varies in composition, but the range of variation is much smaller than for coal. The emissions coefficient used in this report was based on an analysis of some 6,743 recent samples of U.S. natural gas. While there is some residual uncertainty about the exact carbon content of average U.S. natural gas, it is on the order of 1 percent or less.

Petroleum Products. Crude oil is refined into a wide range of petroleum products, each presenting a different set of uncertainties. In general, the carbon content of petroleum products increases with increasing density. Uncertainties in emissions coefficients arise primarily from estimating the wrong density for a fuel, or from mismatching the carbon and energy content of a particular fuel. The emissions factors for liquefied petroleum gas (LPG) and motor gasoline are probably accurate to within 1 to 2 percent. Coefficients for jet fuel and diesel fuel are probably accurate to within 2 to 4 percent, with much of the uncertainty centered in the standard heat contents used. The estimate for residual fuel is more uncertain but probably accurate within 3 to
5 percent, as there are remaining uncertainties about the exact density and carbon content of the fuel.

The uncertainty for some minor petroleum products remains large, in some cases because it has proven difficult to identify exactly how reporters define particular product categories. Products with large remaining uncertainties include petrochemical feedstocks (density and portion of aromatics), lubricants, and waxes and polishes. The uncertainty of the emissions coefficients for these products is probably on the order of 10 percent. Because these products share a large nonfuel use component, their impact on the total carbon emissions figure is muted. Still gas is a highly variable byproduct of the refining process, which is then described as a petroleum product. Thus, the estimated emissions coefficient for still gas may vary by as much as 40 percent.

\section{Adjustments to Energy}

U.S. Territories. Energy data for U.S. territories present certain problems. Published petroleum data for Puerto Rico and the Virgin Islands are considerably less detailed than those for the mainland United States. In particular, there is no estimate of nonfuel use for these territories, and much of the petroleum consumption that could potentially be considered nonfuel use is lumped together into "other petroleum." Hence, the reliability of the emissions estimates is lower than for petroleum emissions estimates generally.

Unmetered Gas Consumption. Since the estimate for unmetered gas consumption is actually a balancing item, the uncertainty of the estimate is very large, on the order of 100 percent. Fortunately, this is only a small source of carbon emissions.

Flare Gas. Estimates of emissions from flare gas are subject to uncertainty from two sources: estimates of the volume of gas flared, and the application of an appropriate emissions coefficient. Estimates of gas flared are based on State-reported volumes of gas "vented or flared" and a State-by-State estimate of the share flared. The 1994 estimate of all vented and flared gas was 228,336 million cubic feet. States may define "flared" gas differently. This suggests that estimates may be upwardly biased by the inclusion of low carbon emitting gases in the statistics, but the degree of bias is unknown.

The emissions coefficient applied to flare gas represents the average coefficient for natural gas samples with

${ }^{194}$ Energy Information Administration, Monthly Energy Review, DOE/EIA-0035(96/05) (Washington, DC, May 1996), pp. 147 and 148. 
heat contents between 1,100 and 1,127 Btu per standard cubic foot. The EIA estimates the heat content of "wet" gas at 1,110 Btu per standard cubic feet. ${ }^{195}$ Anecdotal evidence suggests that most flared gas is flared at gas processing facilities, where the wet gas energy content would be representative. However, if flared gas is mostly "rich" associated gas with a heat content between 1,300 and 1,400 Btu per standard cubic feet, the current coefficient seriously biases estimates downward. Alternatively, it is possible that flare gas from treatment plants is "off spec" gas with a large content of hydrogen sulfide or inert gas and, hence, an emissions coefficient lower than the one actually used.

\section{Other Sources of Carbon Emissions}

The principal source of uncertainty in cement manufacture is the lime content of cement, which is estimated to within about 3 percent. There may also be a degree of imprecision in the estimate of cement production, due to possible production in Puerto Rico (excluded in this report) and limitations on the inherent.accuracy of the Interior Department data used to calculate the estimate.

A second source of uncertainty, common to all the industrial estimates, is the use of stoichiometric computations to estimate emissions. This method calculates an emissions factor based on a chemical reaction known to have taken place. It assumes, in effect, that the product produced (cement, lime, soda ash) is 100 percent pure, and that no raw materials are wasted in its production. In practice, impurities in the output would tend to reduce emissions below the stoichiometric estimate, while "wastage" of raw materials would tend to raise emissions above the estimate.

\section{Excluded Sources}

Appendix $D$ lists several sources of emissions that are excluded because of uncertainty. Sources excluded because of insufficient data include emissions from natural gas plants, emissions from shale oil production, and carbon dioxide in geothermal steam. Taking what is known about all excluded sources, additional emissions would probably be less than 10 million metric tons, or less than 1 percent of estimated emissions. Nonetheless, their exclusion does slightly bias the estimate downward. There are almost certainly other sources of carbon emissions unknown to the authors of this report. There is no way to estimate the impact of such unknown additional sources.

\section{Methane}

Estimates of methane emissions are, in general, substantially more uncertain than those for carbon dioxide. Methane emissions are rarely systematically measured. Where systematic measurements have been made, data are restricted to a small portion of the emission sites and a few years. In order to use these data to sufficiently estimate emissions for the full population of emitters, and to develop time-series emissions estimates, scaling mechanisms and sampling techniques must be applied, which will introduce additional error.

Where no systematic measurements have been made, estimation methods rely on a limited set of data applied to a large and diverse group of emitters. However, as additional data comes available each year, uncertainty in emissions estimates declines or, at a minimum, is more clearly delineated. In this year's report, additional information on emissions from oil and gas operations and municipal wastewater was incorporated into the estimates, significantly reducing uncertainty levels for these sources.

\section{Coal Mining}

Emissions from coal mines are currently the fourthlargest source of methane emissions in the United States-behind landfills, oil- and gas-related emissions, and domestic livestock-and accounts for approximately 13 percent of national methane emissions. Methane emissions from coal mining have five sources: ventilation systems in underground mines, degasification systems in underground mines, emissions from surface mines, post-mining activities, and emissions from abandoned or closed mines. Only the first four are included in emissions estimates, because data on emissions from abandoned mines are lacking. The uncertainty associated with estimates of emissions from each of the sources included varies considerably and according to the year of the estimate. Based on comparison with other estimates recently published, the overall uncertainty of estimates for emissions from coal mines is probably about 35 percent. ${ }^{196}$

Emissions from ventilation systems in the Nation's gassiest mines are measured on a quarterly basis by the Mine Safety and Health Administration (MSHA). The Bureau of Mines (BOM) has developed a database from MSHA reports for all mines emitting more than 100,000 cubic feet of gas per day. Data on emissions from this source are available for 1985, 1988, 1990, and 1993.

\footnotetext{
${ }^{195}$ Energy Information Administration, Annual Energy Review 1993, DOE/EIA-0384(93) (Washington, DC, July 1994), p. 344.

${ }^{196}$ S.D. Piccot, S.S. Masemore, E. Ringler, and D.A. Kirchgessner, "Developing Improved Methane Emission Estimates for Coal Mining Operations," Presented at the 1995 Greenhouse Gas Emissions and Mitigation Research Symposium (U.S. Environmental Protection Agency, June 27-29, 1995).
} 
Although the measurements themselves should be reasonably accurate, each measurement represents a point in time. Variations in methane emissions across time (e.g., resulting from changes in operating practices) suggest an uncertainty in the range of 10 to 40 percent. The EPA has measured coal mine methane emissions estimates from 1990 through 1994. These estimates exhibit ranges of about 3 to 5 million metric tonnes, giving an uncertainty of 67 percent.

Estimates of emissions from the ventilation systems of nongassy mines are scaled to emissions estimates for 1988 developed by the U.S. Environmental Protection Agency (EPA). ${ }^{197}$ The EPA estimates emissions from nongassy mines at 2 percent of total emissions from the ventilation systems of underground coal mines. Thus, an error as high as 100 percent for this source would add less than 1 percent to the total estimate.

Emissions from degasification systems may be the single largest source of uncertainty in estimates of emissions from coal mines. The estimation method used in this report scales emissions to estimates of emissions for 1988 developed by the EPA. Measurements of emissions were limited to a few mines, with the remainder of the estimate based on known emissions from ventilation systems and estimated recovery efficiencies of degasification systems. The recovery efficiencies have an uncertainty in the neighborhood of 20 percent.

Reliable measurements of emissions from surface mines are available for only five sites. Thus, estimates for this report were based on an emissions range supplied by the Intergovernmental Panel on Climate Change (IPCC) ${ }^{198}$ The range of emissions suggested by the IPCC implies an uncertainty range of plus or minus 75 percent. However, estimates of emissions extrapolated from the five measured sites suggest an uncertainty level of less than 10 percent. ${ }^{199}$ Assuming the larger uncertainty level would add only about 10 percent to the overall uncertainty of estimates of emissions from coal mines, because the volume of emissions from surface mines is relatively insignificant.

Emissions from post-mining activities are also estimated on the basis of an emissions range supplied by the
IPCC. This emissions range implies an uncertainty in the area of plus or minus 60 percent. However, the magnitude of emissions from this source is similar to that of emissions from surface mines, thus also contributing about 10 percent to the overall uncertainty of coal mine emissions estimates.

\section{Oil and Gas Operations}

The uncertainty associated with emissions estimates from oil and gas operations can be divided into two areas: uncertainty associated with estimates for production, transmission, and distribution; and uncertainty in estimates of emissions from gas venting.

Estimates of emissions from production, transmission, and distribution of natural gas are calculated by extrapolating measured emissions data for a small number of emission sources to the full U.S. natural gas system. This is done by using data obtained from a sample of emissions sources to develop individual emissions factors for each of the components in the natural gas system, such as engines, compressors, pipelines, wellheads, and regulators. Emissions factors are then multiplied by an activity factor that represents either the number of units in the source category, or the level of usage for such units.

In previous editions of Emissions of Greenhouse Gases in the United States, the ELA adopted emissions factors used in a 1990 report on anthropogenic methane emissions prepared by the U.S. Environmental Protection Agency (EPA). ${ }^{200}$ These factors were based on very small or nonrepresentative samples. Emissions factors from oil and gas wells were based on four model facilities. Emissions factors for distribution pipeline were based on the distribution networks of two California utilities that consisted of mostly new, low-leakage plastic pipeline. Because much of the Nation's distribution pipeline continues to be cast iron with a greater propensity to leak, these emissions factors biased estimates substantially downward.

For this year's report, EIA adopted emissions factors from a more recent study funded jointly by EPA and the Gas Research Institute (GRI). ${ }^{201}$ The EPA/GRI

${ }^{197}$ U.S. Environmental Protection Agency, Anthropogenic Methane Emissions in the United States: Estimates for 1990 (Washington, DC, April 1993).

${ }^{198}$ Intergovernmental Panel on Climate Change, Greenhouse Gas Inventory Reference Manual, IPCC Guidelines for National Greenhouse Gas Inventories, Vol. 3 (Paris, France, 1995), pp. 1.98-1.99.

${ }^{199}$ S.D. Piccot, S.S. Masemore, E. Ringler, and D.A. Kirchgessner, "Developing Improved Methane Emission Estimates for Coal Mining Operations," Presented at the 1995 Greenhouse Gas Emissions and Mitigation Research Symposium (U.S. Environmental Protection Agency, June 27-29, 1995).

${ }^{200}$ U.S. Environmental Protection Agency, Office of Air and Radiation, Anthropogenic Methane Emissions in the United States: Estimates for 1990 (Washington, DC, April 1993), p. 2-22.

${ }^{201}$ M.R. Harrison and R.M. Cowgill, Tier 2 Summary of Methane Emissions from the Natural Gas Industry, Draft Final Report, Prepared for the Gas Research Institute and the U.S. Environmental Protection Agency (January 1996). 
study capitalized on an extended field sampling program and a statistical framework to meet predetermined accuracy goals. The more recent study benefitted from data that had not been previously available on emissions from pneumatic devices and compressors, the number of metering and regulating stations, and emissions from customer meters. The EPA/GRI study also gained from the inclusion of distribution systems with cast iron pipe in their measurement samples. ${ }^{202}$ Together, these sources produced about 1.5 million metric tons more methane in 1992 than had been estimated previously.

While the use of the improved emissions factors from the EPA/GRI report does reduce the overall uncertainty of EIA's emissions estimate from more than 100 percent on the high end of the range, significant uncertainty remains. In developing their emissions factors, EPA/GRI did not use random sampling or stratified random sampling methods. Instead, sites for measurement were selected at random from known lists of facilities, such as GRI or American Gas Association (AGA) member companies. Selected companies were not, however, required to participate. Participating companies were asked to choose representative sites for sampling rather than one-of-a-kind facilities. ${ }^{203}$ Using this sampling technique, the uncertainty of the point estimate of 1992 emissions developed for the EPA/GRI report was plus or minus 35 percent.

The EIA developed time-series emissions estimates for the natural gas industry based on the estimate for 1992 produced by EPA/GRI. As capital stock is replaced or added to the natural gas system, emissions factors may change somewhat. Thus, the use of time-series estimates probably adds some error, though overall uncertainty should remain below \pm 50 percent.

Estimates of emissions from venting are also uncertain. The EIA maintains statistics on gas vented or flared as reported on a State-by-State basis, but no distinction is made between venting and flaring in those statistics. Gas flared releases carbon dioxide rather than methane. This report estimates the national share vented on the basis of the estimated share vented for each State.

An additional uncertainty associated with estimates of methane vented is methane vented at "stripper wells." Associated natural gas production at oil wells producing less than 10 barrels per day may be at pressures and volumes too low to be of commercial value. The gas may be vented or merely evaporate from storage tanks. Such emissions are not captured in any data series. The magnitude of the emissions is impossible to estimate, but "stripper wells" comprise 14 percent of U.S. oil production.

\section{Combustion-Related Emissions}

Most methane emissions from stationary combustion are the result of wood burning in residential woodstoves. Because estimates of wood consumption as well as the maintenance and efficiency of residential woodstoves are highly uncertain, estimates of emissions from this source may vary by more than an order of magnitude.

Methane emissions from mobile combustion may be larger than the estimate offered in this report, but it is unlikely that they are significantly smaller. Emissions factors for mobile transportation assume a well-maintained fleet. A fleet of inadequately maintained vehicles may have as much as 10 times the level of emissions of a fleet of well-maintained or new vehicles. Although much of the U.S. fleet is well-maintained, a portion is old and/or poorly maintained.

\section{Landfills}

Estimates of methane emissions from landfills were broken into two sources: emissions from waste contained in 105 mostly large landfills with gas recovery systems; and emissions from waste contained in all other landfills. Uncertainties associated with estimates of emissions for these two sources differ substantially.

Emissions for many of the 105 mostly large landfills were estimated for 1992, based on volumes of gas recovered multiplied by gas recovery efficiency. ${ }^{204}$ Gas recovery efficiency was estimated, with an associated uncertainty of plus or minus 25 percent. For years other than 1992, emissions from this source were estimated using a model of landfill waste emissions that is benchmarked to the 1992 data. The model parameters include a low yield and high yield scenario that imply an uncertainty of 35 percent.

Emissions from all other landfills were also estimated using an emissions model. This model's input parameters could vary by 30 percent from the mean. A

\footnotetext{
${ }^{202}$ M.R. Harrison and R.M. Cowgill, Tier 2 Summary of Methane Emissions from the Natural Gas Industry, Draft Final Report, Prepared for the Gas Research Institute and the U.S. Environmental Protection Agency (January 1996), pp. 63-64.

${ }^{203}$ M.R. Harrison and R.M. Cowgill, Tier 2 Summary of Methane Emissions from the Natural Gas Industry, Draft Final Report, Prepared for the Gas Research Institute and the U.S. Environmental Protection Agency (January 1996), p. 23.

${ }^{204}$ S.A. Thorneloe, M.R.J. Doorn, L.A. Stefanski, M.A. Barlaz, R.L. Peer, and D.L. Epperson, “Estimate of Methane Emissions from U.S. Landfills," prepared for U.S. Environmental Protection Agency, Office of Research and Development (April 1994).
} 
crucial input into the model is amount of waste in place. The amount of waste in place was calculated from estimates of waste landfilled annually between 1960 and 1994 and using a regression equation to backcast waste flows from 1940 to 1960 . The range of published estimates for years in which multiple sources were available suggests an uncertainty in the neighborhood of plus or minus 33 percent, while the error associated with the regression equation probably adds another 2 to 10 percent additional uncertainty. ${ }^{205}$

The ratio of waste in place in the 105 landfills relative to that in all other landfills was assumed to remain constant over time. This may be misleading, since the total number of landfills has been declining, with greater shares of waste believed to be directed toward larger landfills. Because those landfills with measured emissions for 1992 are likely to have higher-thanaverage emissions per ton of waste, estimates may be biased upward in earlier years.

\section{Domestic and Commercial Wastewater Treatment}

Methane emissions from domestic and commercial wastewater treatment was estimated by IPCC's $\mathrm{s}^{206}$ simplified approach, which is based on the following assumptions: (1) each person contributes $0.5 \mathrm{~kg}$ per day of $\mathrm{BOD}_{5}$ to municipal wastewater; (2) 15 percent of this wastewater is treated anaerobically; and (3) anaerobic treatment yields $0.22 \mathrm{~kg}$ of methane per $\mathrm{kg}$ of $\mathrm{BOD}_{5}$ treated. These assumptions were developed for developed countries in general and there is considerable uncertainty regarding their applicability to the United States.

Per capita organic loadings of municipal wastewater in developed nations ranges from 0.024 to $0.091 \mathrm{~kg}$ $\mathrm{BOD}_{5} /$ day. Organic loadings depend on such factors as the amount of kitchen wastes that are discharged to sewers and the degree to which industrial wastewaters are discharged to municipal wastewater treatment systems. Wastewater treatment methods that are potential sources of methane include anaerobic digesters, facultative and anaerobic lagoons, and septic tanks. However, reliable information on the quantity of wastewater treated by each of these methods is not available. The IPCC emissions factor of $0.22 \mathrm{~kg}$ of methane per $\mathrm{kg}$ of
$B O D_{5}$ is based on an estimate for lagoons in Thailand. ${ }^{207}$ The applicability of this factor to treatment methods in the United States is uncertain.

A further source of uncertainty is the ultimate fate of methane generated from wastewater in the United States. As in the case of landfill methane, wastewater methane generated in sewage treatment plants may often be combusted to control odors or emissions of volatile organic compounds. Conceptually, the amount of methane combusted should be deducted from estimated emissions. However, the EIA is not aware of any information on the amount or extent of combustion of off-gases from sewage treatment plants.

\section{Enteric Fermentation in Domesticated Animals}

Estimates of methane emissions from enteric fermentation in domesticated animals are less uncertain than those for other sources of methane emissions. Emissions estimates are a function of an emissions factor for each animal group, based on their diet and energy usage multiplied by their population. Animal population data have recently been revised by the U.S. Department of Agriculture, and the magnitude of revisions shows that population estimates are likely to be accurate within 5 percent. The energy requirements and diets of cattleby far the largest source of emissions from enteric fermentation-have been carefully studied. There is some uncertainty associated with estimates of the energy requirements of other animals, but even if this uncertainty was as high as $\mathbf{5 0}$ percent, the impact on the overall estimate would be no more than 3 percent.

There is also some uncertainty associated with the average size of cattle, which could affect the animals' energy requirements. Cattle sizes have been changing rapidly over the past decade in response to market forces. This report uses slaughter weights as a proxy for average animal size, a method that may be imperfect. The slaughter sizes vary over time by approximately 33 percent.

\section{Solid Waste of Domesticated Animals}

The maximum amount of methane that a given amount of an animal's waste can produce under optimal anaerobic conditions can be measured fairly accurately in

\footnotetext{
${ }^{205}$ Franklin Associates, Ltd., Characterization of Municipal Solid Waste in the United'States: 1994 Update (prepared for U.S. Environmental Protection Agency, Office of Solid Waste and Emergency Response); and "1994 Nationwide Survey: The State of Garbage in America," Biocycle (various years).

${ }^{206}$ Intergovernmental Panel on Climate Change, Greenhouse Gas Inventory Reference Manual, IPCC Guidelines for National Greenhouse Gas Inventories, Vol. 3 (Paris, France, 1995), pp. 6.21-6.23.

${ }^{207}$ U.S. Environmental Protection Agency, International Anthropogenic Methane Emissions: Estimates for 1990, EPA 230-R-93-010 (Washington, DC, January 1994), p. 10-15.
} 
the laboratory. However, the share of that production realized under various waste management regimens is much more uncertain. The emissions vary with ambient air temperatures and, depending on the waste management system, may change by anywhere from 1 to 60 percent as the temperature changes. For this report, all animal waste was assumed to be handled at air temperatures between 59 and $77^{\circ} \mathrm{F}$. Overestimating the average temperature at which waste is handled would bias emissions estimates upward.

Emissions are tied to the amount of waste an animal produces. The amount of waste produced is a function of size and diet. Thus, changes in animal sizes, which are difficult to monitor, create additional uncertainty. As discussed above, slaughter weights have been used as an imperfect tool for capturing changes in animal size. This proxy measure varies by 30 percent over time. Uncertainty in estimates of animal populations is on the order of 5 percent or less.

\section{Wetland Rice Cultivation}

There are large uncertainties associated with the estimate of methane emissions from wetland rice cultivation. Emissions estimates are based on several studies of rice paddies in the United States, which provide daily emissions rate ranges. Studies have shown large seasonal and time-of-day variations in methane flux. Many variables affect methane production in rice fields, including soil temperature, redox potential, and acidity; substrate and nutrient availability; addition of chemical and/or organic fertilizers; rate of methane oxidation; and rice plant variety. The wide range of emissions provided by different researchers suggests an uncertainty of several hundred percent. ${ }^{208}$

\section{Crop Residue Burning}

Estimates of emissions from the burning of crop residues are calculated using the default method recommended by the IPCC. ${ }^{209}$ This method assumes a carbon content of about 45 percent of dry matter and that 10 percent of crop residues are burned. The carbon content probably is uncertain to plus or minus 10 percent, and the share of crop residues burned in the United States is likely to be much smaller than the 10 percent default parameter used. Thus, estimates are likely to overstate actual emissions.

\section{Chemical Production}

Estimates of methane emissions from chemical production are highly uncertain because of the wide variety of production processes and inputs. Organic chemical production requires the cracking and reforming of hydrocarbon bonds. How the bonds crack and reform depends on several variables, including the composition of the feedstock, the temperature of the reaction, the catalyst used, and the reaction vessel. As a result, the quantities of products and byproducts, including methane, vary. Methane may be released through leaks in seals, and valves. Therefore, methane emissions are dependent on the operation and maintenance practices of the producer.

\section{Iron and Steel Production}

There is substantial uncertainty associated with estimates of methane emissions from iron and steel production, with the plausible range of estimates ranging from 80 percent below the point estimate presented in this report, to 100 percent above the point estimate. There are several factors mitigating methane emissions from iron and steel production. The pollution controls used on coke ovens to prevent emissions of volatile organic compounds usually eliminate methane as well. Exhaust gases from blast furnaces that are typically captured and used for fuel contain methane. Because the emissions factors used in this report are global emissions factors provided by the IPCC ${ }^{210}$ they may not accurately portray the level of emission controls found in U.S. plants. Further, the efficacy of these pollution control systems is likely to vary with operation and maintenance techniques.

\section{Excluded Sources}

Appendix $D$ lists several sources excluded because of excessive uncertainty or insufficient data. Known sources excluded from methane emissions estimates are industrial wastewater, abandoned coal mines, industrial landfills, and open dumps. There are other sources of methane that have yet to be identified and thus are

\footnotetext{
${ }^{208}$ R.J. Cicerone, J.D. Shetter, and C.C. Delwiche, "Seasonal Variation of Methane Flux from a California Rice Paddy," Journal of Geophysical Research, Vol. 88 (1983), pp. 7203-7209; C.W. Landau and P.K. Bolich, "Methane Emissions from Louisiana First and Ratoon Crop," Soil Science, Vol. 156 (1993), pp. 42-48; R.L. Sass, F.M. Fisher, S. Lewis, M. Jund, and F. Turner, "Methane Emissions from Rice Fields: Effect of Soil Properties," Global Biogeochemical Cycles, Vol. 8 (1994), p. 135; R.L. Sass, F.M. Fisher, and Y.B. Wang, "Methane Emissions from Rice Fields: The Effect of Floodwater Management," Global Biogeochemical Cycles, Vol. 6 (1992), pp. $249-262$.

${ }^{209}$ Intergovernmental Panel on Climate Change, Greenhouse Gas Inventory Reference Manual, IPCC Guidelines for National Greenhouse Gas Inventories, Vol. 3 (Paris, France, 1995), pp. 4.69-4.72.

${ }^{210}$ Intergovernmental Panel on Climate Change, Greenhouse Gas Inventory Reference Manual, IPCC Guidelines for National Greenhouse Gas Inventories, Vol. 3 (Paris, France, 1994), p. 2.6.
} 
absent from emissions estimates. Excluded sources would invariably add to total emissions, but the magnitude of the additions is impossible to estimate.

\section{Nitrous Oxide}

\section{Fertilizer}

A number of variables are necessary for accurate calculation of nitrous oxide emissions from the application of fertilizer. They may include crop type, soil type, nutrient content of the fertilizer, agricultural management practices, and even climate. In fact, researchers maintain different opinions about the effects, if any, of these variables. While it may be possible to quantify some of the variables, it is highly unlikely that within the next few years sufficient studies will be conducted to determine a precise emissions factor. Therefore, the uncertainty range for the estimate presented in this report is an order of magnitude. Additionally, the estimate does not take into account organic fertilizer from human or farm animal excreta. Although the data are limited, emissions from this type of fertilizer are generally greater than those from mineral fertilizer. ${ }^{211}$ In 1994 nitrous oxide from fertilizer emissions represented approximately 50 percent of U.S. emissions of nitrous oxides and over 90 percent of nitrous oxides from agricultural sources.

\section{Crop Residue Burning}

The accuracy of emissions estimates for crop residue burning is limited, because the practice of burning crop residues in the United States has not been quantified. As described in Chapter 4, a default figure of 10 percent was used in the calculation. This figure is believed to be a maximum representation of the practice, and could possibly be as much as an order of magnitude high.

\section{Stationary Source Combustion}

As the result of improved studies, emissions factors recommended by the IPCC are now limited to one value for each fuel type, regardless of application. Although the emissions factor for coal is 1.4 kilograms of nitrous oxide per terajoule of energy input, emissions may range from 0 to 10 kilograms. For oil, the recommended emissions factor is 0.6 kilogram, with a possible range of 0 to 2.8 kilograms. The range is smallest for natural gas ( 0 to 1.1 kilograms), with 0.1 kilogram as the suggested factor. ${ }^{212}$

The emissions factors were derived from studies of "conventional" combustion facilities (i.e., those equipped with burners and grate combustion, with flame temperatures well beyond $1,000^{\circ} \mathrm{C}$ ). Other types of facilities are used in the United States, adding to the uncertainty of estimates presented in this report.

\section{Adipic Acid Production}

For adipic acid production, emissions estimates are based on three data inputs: production activity, an emissions factor, and emissions abatement activity. The primary reasons for uncertainty are that the amount of production at plants with emissions abatement is unknown, and the effectiveness of those abatement techniques in eliminating nitrous oxide is unknown. Additionally, the emissions factor for adipic acid production was determined by stoichiometry. Moreover, plant-specific production figures must be estimated by disaggregating total adipic acid production using existing plant capacities. Therefore, any national estimate will be an imprecise figure if the conversion of nitric acid to adipic acid is less than 100 percent efficient.

\section{Nitric Acid Production}

The emissions factor for nitric acid production is also uncertain. The DuPont data indicate a range of emissions from 2 to 9 grams of nitrous oxide per kilogram of acid production. Since the midpoint of this range was used in the calculation, estimates may err by as much as 65 percent. As explained in Chapter 4, applying this emissions factor range to total production also adds uncertainty, because the emissions reported at the DuPont plant may not be representative of emissions at all nitric acid production plants.

\section{Criteria Pollutants}

The emissions estimates presented in Chapter 6 are taken from data in National Air Pollutant Emission Trends, 1900-1994, a report published by the EPA Office of Air Quality Planning and Standards. Although true values of criteria pollutant emissions are not known, the EPA states that, "beginning with the 1900 to 1992 report, EPA set the primary goal of preparing emission

\footnotetext{
${ }^{211}$ A.R. Mosier, "Nitrous Oxide Emissions from Agricultural Soils," in A.R. van Amstel (ed.), International IPCC Workshop Proceedings: Methane and Nitrous Oxide, Methods in National Emissions Inventories and Options for Control (Bilthoven, Netherlands: RIVM, 1993), p. 278.

${ }^{212}$ Intergovernmental Panel on Climate Change, Greenhouse Gas Inventory Reference Manual, IPCC Guidelines for National Greenhouse Gas Inventories, Vol. 3 (Paris, France, 1995), p. 1.50.
} 
trends that would also represent the best available estimates of emissions. ${ }^{\prime 213}$ The EPA also explains that one of the difficulties they experience in providing emissions estimates is balancing consistency of estimation methods with completeness and accuracy of data. Therefore, as new methods and data become available, emissions estimates may be revised.

\section{Land Use Issues}

Estimates of carbon flux from U.S. forests are subject to several potential sources of error. Uncertainty is introduced into the estimation method when results of small-scale studies in specific ecosystems are applied to different ecosystems or to large areas. This is particularly true for the estimate of soil carbon flux, leading EIA to provide low, median, and high estimates for this component ranging from 0 to 127 million metric tons. The estimates of forest carbon flux are also subject to bias from applying data from past studies that do not represent all forest conditions, from modeling errors, and from errors in converting estimates from one reporting unit to another. Forest Service researchers Richard Birdsey and Linda Heath (the primary source of data used by EIA in its estimates of aggregate carbon flux) did not attempt to estimate the magnitude of these errors, but believe that they are probably small.

In addition, there are two methodological problems common to adding carbon sources and sinks derived from land use data to more conventional greenhouse gas emissions:

- Distinguishing Between Anthropogenic and Biogenic Activities. Humans plant trees, but trees also reproduce themselves. Generally, given enough time, biomass grows to the capacity limits of the ecosystem. It is therefore difficult to determine which activities are biogenic and which are anthropogenic when both activities occur in tandem. If humans plant forests and protect them as they grow, that is in principle an anthropogenic activity. Humans also abandon farmland, however, and trees can grow back by themselves, without human intervention.
There are parts of the United States (some areas in national parks, or parts of the interior of Alaska, for example) that remain close to an undisturbed state and continue to add biomass without human intervention. It is less clear that this carbon sequestration should "count" as anthropogenic. The broadest definition of anthropogenic would take the view that because humans control all land use in the United States, all land use decisions, whether of omission or commission, are anthropogenic acts. This argu'ment might lead to the conclusion that by not cutting down and burning all its forests, the United States has saved 50 billion metric tons of carbon emissions in each year in which the forests were not cut down. Alternatively, too narrow a definition of anthropogenic could exclude unambiguous reforestation activities. There is no single universally acceptable definition of anthropogenic for the purpose of making an emissions inventory, and any decision that is made will inevitably be arbitrary to some degree.

- Assigning Anthropogenic Emissions and Sinks to a Particular Calendar Year. After a tree is planted, it can grow and sequester carbon for many years. The period during which a tree grows to its full height varies from a few decades for the fastergrowing species to more than a century for slowergrowing species. Thus, trees planted in 1990 will absorb some amount of carbon dioxide from the atmosphere every year for decades to come. Similarly, surviving trees planted in 1950 are still absorbing carbon dioxide from the atmosphere today. Unfortunately, the future carbon-absorbing properties of current tree planting depend on the preservation of the forest through time. Thus, attributing all of the carbon sequestration of the next 100 years to a tree planted today is to bet on a century of continued intent and luck, and creates an opportunity for misstating the long-run sequestration potential of timberland that is repeatedly harvested. Alternatively, accurately estimating carbon sequestration today or in the future requires an understanding and accounting of changes in land use made in the past.

\footnotetext{
${ }^{213}$ U.S. Environmental Protection Agency, Office of Air Quality Planning and Standards, National Air Pollutant Emission Trends, 1900-1993, EPA-454/R-94-027 (Research Triangle Park, NC, October 1994), p. 1-3.
} 


\section{Appendix D \\ Emissions Sources Excluded}

Certain sources of greenhouse gas emissions are not included in the estimates presented in the main body of this report. These omissions have been deemed necessary due to lack of essential data, highly speculative estimation methods, or classification as a "natural" source.

\section{Biofuel Combustion}

The carbon found in biofuels is the result of atmospheric uptake. During combustion of biofuels, there is an immediate release of this carbon in the form of carbon dioxide. As part of the natural carbon cycle, however, these carbon emissions are reabsorbed over time. Since they produce no net change in the overall carbon budget, such emissions are not included in this report. If the initial flux had been counted, annual carbon dioxide emissions estimates would have been approximately 48 million metric tons higher than reported in Chapter 2 (Table D1).

Emissions are estimated by multiplying EIA energy consumption data for biofuels by the applicable emissions factors. The EIA data used for municipal solid waste include methane recovery from landfills, but since the methane is not used as a biofuel, it has been subtracted for these calculations. Carbon dioxide emissions factors for combustion of wood fuels and municipal solid waste are taken from the EIA report,
Electric Power Annual 1993. ${ }^{214}$ The emissions coefficient for alcohol fuels, 19.67 million metric tons of carbon per quadrillion Btu, was derived specifically for use in this report.

\section{Overseas U.S. Military Oil Consumption}

Domestic military energy consumption is incorporated into U.S. energy statistics. However, energy consumption for overseas operations is a more complex issue. The data can either be reported in the national energy statistics of the host country or included in U.S. export statistics if domestic oil is transported to ships and other facilities. In some circumstances, the oil consumption may go unreported.

Estimating, even roughly, the quantity of oil consumed for overseas military operations is an uncertain procedure. The Defense Fuel Supply Center reports that petroleum sales for 1995 totaled 116.4 million barrels. Of this, approximately 77 percent was acquired domestically, and is assumed to be included in U.S. statistics. A reasonable estimate of military oil consumption not reported elsewhere would, therefore, be 23 percent of total military consumption of jet fuel, middle distillates, and residual oil. ${ }^{215}$ Using this method, emissions for 1995 are estimated at 2.8 million metric tons of carbon (Table D2).

Table D1. Estimated U.S. Carbon Dioxide Emissions from Biofuels, 1988-1995 (Million Metric Tons of Carbon)

\begin{tabular}{c|r|r|r|r|r|r|r|c}
\hline Fuel & 1988 & 1989 & 1990 & 1991 & 1992 & 1993 & 1994 & 1995 \\
\hline Municipal Solid Waste .... & 7.95 & 8.43 & 9.88 & 10.46 & 11.28 & 11.33 & 11.72 & NA \\
Alcohol Fuel .......... & 1.38 & 1.40 & 1.61 & 1.34 & 1.63 & 1.73 & 1.89 & NA \\
Wood and Wood Waste ... & 38.06 & 37.56 & 32.55 & 32.49 & 33.97 & 33.65 & 34.22 & NA \\
Total .............. & 47.39 & 47.39 & 44.04 & 44.29 & 46.88 & 46.71 & 47.83 & NA \\
\hline
\end{tabular}

NA $=$ not available.

Note: Data in this table are revised from the data contained in the previous EIA report, Emissions of Greenhouse Gases in the United States 1987-1994, DOE/EIA-0573(87-94) (Washington, DC, October 1995).

Sources: Underlying energy data from Energy Information Administration, Annual Energy Review 1995, DOE/EIA-0384(95) (Washington, DC, July 1996), Table 10.2. Emissions coefficients for municipal solid waste combustion and wood and wood waste from Energy Information Administration, Electric Power Annual 1993, DOE/EIA-0348(93) (Washington, DC, 1994), Table C3.

\footnotetext{
${ }^{214}$ Energy Information Administration, Electric Power Annual 1993, DOE/EIA-0348(93) (Washington, DC, December 1994).

${ }^{215}$ Gasoline is presumably acquired for motor vehicles and, typically, is accounted for in both domestic and foreign energy statistics.
} 
Table D2. Estimated Carbon Emissions from U.S. Military Operations Abroad, 1988-1995 (Million Metric Tons of Carbon)

\begin{tabular}{c|c|c|c|c|c|c|c|c}
\hline Item & 1988 & 1989 & 1990 & 1991 & 1992 & 1993 & 1994 & 1995 \\
\hline Energy Consumption (Quadrilion Btu) $\ldots$ & 0.31 & 0.26 & 0.25 & 0.30 & 0.12 & 0.20 & 0.18 & 0.14 \\
Carbon Emissions ................ & 5.99 & 4.98 & 4.85 & 5.86 & 2.26 & 3.81 & 3.51 & 2.80 \\
\hline
\end{tabular}

Sources: Energy consumption from Defense Fuel Supply Center, Fact Book (various years). Data converted from fiscal years in source publication into calendar years by weighted average. Carbon emissions from ElA estimates presented in this chapter.

\section{Forest Fires}

Forest fires are known to create greenhouse gas fluxes within the atmosphere over extensive time periods. Specifically, forest fires produce carbon dioxide, methane, and nitrous oxide. Due to carbon uptake that occurs with subsequent regrowth (assumed to balance out the initial carbon flux) and the inability to distinguish emissions from natural versus humaninduced fires, estimates from this source are not included in this report.

\section{Carbon Dioxide Coproduction With Natural Gas}

The carbon dioxide content of natural gas varies by reservoir. Marketed natural gas, however, must consist largely of methane. When natural gas direct from the reservoir does not meet marketable standards, it is treated in a gas processing plant. During treatment, impurities and heavy hydrocarbons are removed from the gas. Excess carbon dioxide is one of the separated compounds, and it is either used industrially (estimates provided in Chapter 2) or vented to the atmosphere.

The EIA reports that 412 billion cubic feet of nonhydrocarbon gases were removed from total natural gas production in 1994. This figure does not take into account the 11 (out of 33) gas-producing States that do not report annual amounts of nonhydrocarbon gases removed. ${ }^{216}$ In its reporting, Texas quantifies commercial carbon dioxide recovery from gas plants. From those data, the EIA is able to make rough estimates of carbon dioxide recovery in other States (Table D3).

In Texas, the amount of nonhydrocarbon gas removed is approximately 2 percent of gross natural gas production. This same ratio is applied to gross production for the nonreporting States. Similarly, the ratio of commercial carbon dioxide production to nonhydrocarbon gas removal in Texas (roughly 90 percent) is applied to other States to determine the total amount of carbon dioxide removed from gas plants in the United States. In order to avoid double-counting with industrial carbon dioxide production, the commercial recovery in Texas is deducted from this total. Any commercial recovery in other States is double-counted; however, due to the lack of data, this is currently unavoidable.

In 1994, carbon dioxide coproduction at natural gas plants was estimated at 5 million metric tons of carbon. Because of its speculative nature, this estimate is not included in the main body of the report. First, there is no basis to support the assumption that the ratios applicable to Texas are generalizable across the country. Second, there is no basis for determining the precise amount of carbon dioxide recovered for commercial use in States other than Texas.

\section{Fermentation}

During the fermentation process, complex organic compounds are split through a variety of chemical reactions. The most common is the anaerobic conversion of sugar into carbon dioxide and alcohol. Fermentation does not create a net flux of emissions, however, because the carbon dioxide produced is reused in the process.

\section{Enhanced Oil Recovery}

As a replacement for natural gas, carbon dioxide is being injected into reservoirs for the purpose of retrieving additional oil. Over time, the carbon dioxide seeps into the producing well, creating a mixture of oil, natural gas, and carbon dioxide. If the energy content is sufficiently high, the gaseous portion of this mix will probably be sent to a gas plant. However, if the energy content is low, the gas is likely to be vented or flared. At this time, there is no basis for the EIA to estimate

\footnotetext{
${ }^{216}$ Energy Information Administration Natural Gas Annual 1994, DOE/EIA-0131(94) (Washington, DC, October 1994), p. 4. The 11 nonreporting States account for approximately 40 percent of domestic gas production.
} 
Table D3. Estimated U.S. Carbon Dioxide Emissions from Natural Gas Plants, 1988-1995 (Billion Cubic Feet, Unless Otherwise Noted)

\begin{tabular}{|c|c|c|c|c|c|c|c|c|}
\hline Item & 1988 & 1989 & 1990 & 1991 & 1992 & 1993 & 1994 & 1995 \\
\hline Total Gross Withdrawals . . . . . & $20,880.2$ & $20,998.8$ & $21,490.5$ & $21,740.2$ & $22,132.2$ & $22,725.6$ & $23,608.7$ & $24,008.0$ \\
\hline States Reporting NHCGR $^{a} \ldots$ & $5,028.3$ & $5,155.8$ & $5,417.2$ & $5,941.8$ & $6,670.4$ & $7,019.8$ & $7,667.7$ & NA \\
\hline$\ldots \ldots \ldots \ldots \ldots$ & $6,918.6$ & $6,881.0$ & $6,907.1$ & $6,898.9$ & $6,708.0$ & $6,816.9$ & $6,911.7$ & NA \\
\hline All Other States $\ldots \ldots \ldots \ldots$ & $8,933.3$ & $8,962.0$ & $9,166.2$ & $8,899.6$ & $8,753.9$ & $8,888.9$ & $9,029.3$ & NA \\
\hline Estimated NHCGR . . . . . & 638.5 & 541.7 & 472.7 & 453.8 & 455.4 & 591.7 & 605.0 & NA \\
\hline States Reporting NHCGR & 315.7 & 203.3 & 133.7 & 102.4 & 100.4 & 229.7 & 227.9 & NA \\
\hline Texas & 144.1 & 159.1 & 155.6 & 173.4 & 180.0 & 184.3 & 196.5 & NA \\
\hline All Other States ${ }^{b}$. & 178.7 & 179.2 & 183.3 & 178.0 & 175.1 & 177.8 & 180.6 & NA \\
\hline Estimated $\mathrm{CO}_{2}$ Removed ${ }^{c}$ & 574.7 & 487.5 & 425.4 & 408.4 & 409.9 & 532.6 & 544.5 & NA \\
\hline $\begin{array}{c}\text { Estimated } \mathrm{CO}_{2} \text { Recovered } \ldots \text {. } \\
\text { States Reporting NHCGR . . . }\end{array}$ & 109.2 & $\begin{array}{c}135.5 \\
*\end{array}$ & 148.9 & $\begin{array}{c}133.5 \\
*\end{array}$ & 176.7 & 186.3 & $\stackrel{191.3}{*}$ & 201.1 \\
\hline $\begin{array}{l}\text { Texas } \ldots \ldots \ldots \ldots \ldots \ldots \\
\text { All Other States } \ldots \ldots \ldots\end{array}$ & $\begin{array}{c}109.2 \\
\star\end{array}$ & 135.5 & 148.9 & $\begin{array}{l}133.5 \\
*\end{array}$ & $\begin{array}{c}176.7 \\
*\end{array}$ & 186.3 & 191.3 & 201.1 \\
\hline Estimated $\mathrm{CO}_{2}$ Emissions & & & 766 & & $?$ & ? & 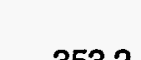 & 1 \\
\hline Million Metric Tons $\mathrm{CO}_{2}$ & 24.5 & 18.5 & 14.6 & 14.5 & 12.3 & 18.2 & 18.6 & NA \\
\hline Million Metric Tons Carbon .. & 6.7 & 5.1 & 4.0 & 3.9 & 3.4 & 5.0 & 5.1 & NA \\
\hline
\end{tabular}

*Less than $\mathbf{5 0}$ million cubic feet.

${ }^{a}$ Nonhydrocarbon gases removed.

'Assumes that 2 percent of All Other States' gas withdrawals are nonhydrocarbon gases.

${ }^{c}$ Assumes that 90 percent of the total nonhydrocarbon gas removed is carbon dioxide.

$\mathrm{NA}=$ not available.

Note: Totals may not equal sum of components due to independent rounding.

Sources: Railroad Commission of Texas, Annual Summaries of Texas Natural Gas (various years), and Energy Information Administration, Natural Gas Annual, DOE/EIA-0131 (various years).

the quantity of added carbon dioxide that is vented or flared. However, the annual amount of carbon dioxide used for enhanced oil recovery is probably on the order of 12 million metric tons. ${ }^{217}$ Emissions are, therefore, some fraction of that figure.

\section{Lead Smelting}

Smelting of lead includes a stage in which limestone undergoes calcination. As described in Chapter 2, carbon dioxide is released as a byproduct of the calcination reaction. Emissions estimates cannot be calculated for this report because there are no known statistics regarding the amount of limestone used in lead smelting. The EIA is currently researching alternative data sources in an effort to include estimates of these emissions in future reports.

\section{Abandoned Coal Mines}

As noted in Appendix A, recent research indicates that a sample of 20 abandoned coal mines collectively emitted some 25,000 metric tons of methane in 1994, and the researchers believe, extrapolating from the sample, that national-level emissions from this source may be as high as 280,000 metric tons. ${ }^{218}$ As more research is published, particularly on extrapolating the sample into national-level emissions, this source will probably be included in future reports.

\section{Shale Oil Plants}

Synthetic crude oil can be produced by thermally decomposing shale oil in a large-scale retort. To provide the required heat, residual hydrocarbons in the waste

\footnotetext{
${ }^{217}$ The U.S. Department of Commerce reports total sales of industrial carbon dioxide at approximately 17 million metric tons annually, while Freedonia Group, Inc., reports that approximately 5 million metric tons are used for purposes other than enhanced oil recovery.

${ }^{218}$ S.D. Piccot, S.S. Masemore, E. Ringler, and D.A. Kirchgessner, “Developing Improved Methane Emission Estimates for Coal Mining Operations," Presented at the 1995 Greenhouse Gas Emissions and Mitigation Research Symposium (U.S. Environmental Protection Agency, June 27-29, 1995).
} 
shale are burned, creating carbon emissions. The only commissioned U.S. shale oil plant was operated by the Unocal Corporation from 1985 to 1990 . During that time, 4.6 million barrels of synthetic crude were produced. In its last and most productive year, this plant may have emitted 50,000 metric tons of carbon. ${ }^{219}$

\section{Geothermal Steam}

Geothermally pressurized steam can be sent through a turbine to generate electricity. Frequently, the steam contains some quantity of dissolved carbon dioxide. After the steam has passed through the turbine, it condenses into water, and any carbon dioxide is released to the atmosphere. Currently, there are no data to link carbon dioxide content with specific sites and production. However, it is known that at the principal geothermal site in the United States (The Geysers, near Guerneyville, CA), the steam has a relatively high concentration of dissolved carbon dioxide. If all geothermal power in the United States were generated at The Geysers, carbon emissions would have been approximately 53,000 metric tons in $1993 .^{220}$ If better documentation becomes available in the future, estimates from this minor source of emissions will be incorporated into the report.

\section{Methane Emissions from Wetlands}

Wetlands are a known source of methane. Environments low in oxygen, combined with abundant organic matter, are conducive to the creation of methane, and wetlands meet both criteria. Wetlands cover approximately 274 million acres of land in the United States and are a potentially important source of atmospheric methane.

The stock of natural wetlands in the United States has diminished considerably over the past two centuries, which should, in principle, have reduced methane emissions from wetlands (the EIA is unaware of research proving or disproving this principle). A recent study of wetland losses concluded that the United States had lost approximately 30 percent of its wetlands between colonial times and the mid-1980s. Almost all of this loss has occurred in the lower 48 States, which have lost 53 percent of their original wetlands. ${ }^{221}$ Ten States-Arkansas, California, Connecticut, Illinois, Indiana, Iowa, Kentucky, Maryland, Missouri, and Ohio-have lost 70 percent or more of their original wetland acreage. By the mid-1980s, a total of approximately 119 million acres had been lost from the original U.S. total.

An update of the wetlands study indicates that 654,000 acres were converted from wetlands to other uses between 1982 and 1987, and that an additional 431,000 acres were converted between 1987 and 1991.222 Extrapolating from these data, it is estimated that wetlands in the United States are currently destroyed at a rate of approximately 86,000 acres per year. Wetlands, also known as swamps and marshes, have historically been drained or filled in for agriculture, land development, and mosquito control, although it is currently illegal to drain or fill a wetland without a permit from the U.S. Army Corps of Engineers. It is difficult to find information on the conversion of other land categories to wetlands. It is assumed that the number and extent of wetland creations is small enough to leave the above loss estimates essentially unchanged.

Estimates of global methane fluxes from wetlands suggest that methane emissions from temperate-zone wetlands are minimal-typically between 5 and $10 \mathrm{mil}-$ lion metric tons of methane per year for worldwide temperate-zone wetlands (which include U.S. wetlands)-when compared with estimated global wetlands emissions of 110 million metric tons. ${ }^{223}$ The U.S. share of all temperate-zone wetlands is about 57 percent, and temperate-zone wetlands lost during the 1980 s accounted for about 0.5 percent of U.S. wetlands at the beginning of the period. Consequently, the reduction in natural methane emissions from wetlands lost might be on the order of $0.57 \times 0.005 \times 5$ to 10 million metric tons of methane, or from 10,000 to 20,000 metric tons of methane annually over the decade.

\footnotetext{
${ }^{219}$ This calculation is based on information about the shale oil processing from the U.S. Department of Energy, Energy Technology Characterizations Handbook: Environmental Pollution and Control Factors, Third Edition, DOE/EP-0093 (Washington, DC, March 1983), pp. 32-39, which suggests roughly 70 percent thermal efficiency.

${ }^{220}$ U.S. Department of Energy, Energy Technology Characterizations Handbook: Environmental Pollution and Control Factors, Third Edition, DOE/EP-0093 (Washington, DC, March 1983), pp. 188-189.

${ }^{221}$ T. Dahl, U.S. Department of the Interior, Fish and Wildlife Service, Wetlands Losses in the United States: 1780's to 1980's (Washington, DC, 1990).

${ }^{222}$ U.S. Department of Agriculture, Soil Conservation Service, 1991 Update of National Resources Inventory Wetlands Data for Non-Federal Rural Lands (Washington, DC, not dated), p. 4.

${ }^{223}$ See E. Matthews and I. Fung, "Methane Emissions from Natural Wetlands: Global Distribution, Area, and Environmental Characteristics," Global Biogeochemical Cycles, Vol. 1, No. 1 (March 1987); and K. Bartlett and R.C. Harriss, "Review and Assessment of Methane Emissions from Wetlands," Chemosphere, Vol. 26, Nos. 1-4 (1993), p. 280.
} 


\section{Land Use Changes Affecting Methane and Nitrous Oxide}

The scientific literature suggests that grasslands and forest lands are both weak natural sinks for methane and weak natural sources for nitrous oxide. Natural soils apparently serve as methane sinks: well-aerated soils contain a class of bacteria called "methanotrophs" that use methane as food and oxidize it into carbon dioxide. Experiments indicate that cultivation reduces methane uptake by soils and increases nitrous oxide emissions.

One report indicates that methane uptake in temperate evergreen and deciduous forests in the United States ranged from 0.19 to 3.17 milligrams (measured in carbon units) per square meter per day, equivalent to the uptake of 36.8 to 624.4 metric tons of methane per million acres per year. The range is larger for agricultural lands: 0.2 to 6.3 milligrams per square meter per day. Estimates for methane uptake by the abandonment of farmland range from 0.6 to 6.1 milligrams per square meter per day. While all of these ranges are wide, the total amount of methane in question is less than 1 percent of methane emissions from anthropogenic sources.

Of all greenhouse gases discussed in Chapter 7, the least amount of data is available for nitrous oxide. It is known that conversion of forests and grasslands to cropland accelerates nitrogen cycling and increases nitrous oxide emissions from the soil. It is not known with certainty by how much. ${ }^{224}$ Some estimates have been made of the difference between fertilized and unfertilized soils. According to one study, unfertilized soils had emissions of 0.25 to 0.35 milligrams (measured in nitrogen units) per square meter per day, while emissions from fertilized soils ranged from 0.6 to 1.65 milligrams per square meter per day. ${ }^{225}$ Thus, abandoning fertilization should reduce nitrous oxide emissions by 0.35 to 1.3 milligrams per square meter per day-the equivalent of 86 to 321 metric tons of nitrous oxide per million acres per year.

Applying this figure to the 35 million acres of cropland idled between 1982 and 1992 implies a reduction in nitrous oxide emissions ranging from 3,010 to 11,235 metric tons annually. In principle, however, about three-quarters of the reduction in emissions from this source should be captured by reduced application of nitrogen fertilizers; thus, reporting emissions reductions using this method would result in significant double counting of units already included in the agriculture statistics in Chapter 4.

If such estimates are to be applied to emissions inventories, a problem of crediting the uptakes applies. Removing an acre of farmland from production in a particular year creates a permanent annual methane sink that will absorb small additional amounts of methane each year thereafter, or at least until the use of the land changes. The method that should be used to credit such permanent reductions to a particular year is not obvious.

As noted in the Executive Summary, emissions of nitrous oxide were only 2.2 percent of U.S. GWPweighted emissions of greenhouse gases in 1994. Of those emissions, it is difficult to say what percentage resulted from land uses, primarily due to the wide range of estimates concerning the magnitude of nitrous oxide emissions from nitrogen fertilizer use (which in any case should be included in agriculture statistics instead of land use statistics-see Chapter 4), and the lack of research data on nitrous oxide emissions from forest and grassland soils.

One report, based on experimental data, indicates that methane uptake in temperate evergreen and deciduous forests in the United States ranges from 0.19 to 3.17 milligrams (measured in carbon units) per square meter per day, equivalent to the uptake of 36.8 to 624.4 metric tons of methane per million acres per year. ${ }^{226}$ Thus (assuming no methane uptake at all from previous use), adding 6 million acres of forest land from 1987 to 1992 should increase methane absorption by 221 to 3,746 metric tons per year. Using the same numbers, all forest land in the United States may remove from 27,122 to 460,183 metric tons of methane per year. Comparing this figure with U.S. anthropogenic methane emissions of about 31 million metric tons per year, as estimated in this report, indicates that the magnitude of methane uptake by natural soils is not great.

Another report in the scientific literature indicates that some sample plots of pastureland in the United States have methane uptake rates of 4.1 milligrams (measured

\footnotetext{
${ }^{224}$ See A. Mosier, "Nitrous Oxide Emissions from Agricultural Soils," paper presented at RIVM International Workshop on Methane and Nitrous Oxide: Methods in National Emission Inventories and Options for Control (Amersfoort, The Netherlands, February 3-5, 1993).

${ }^{225}$ A. Mosier and D. Schimel, "Influence of Agricultural Nitrogen on Atmospheric Methane and Nitrous Oxide," Chemistry \& Industry, Vol. 2 (December 1991), p. 875.

${ }^{226}$ P.A. Steudler et al., "Influence of Nitrogen Fertilization on Methane Uptake in Temperate Forest Soils," Nature, Vol. 341 (September 28, 1989), pp. 314-315.
} 
in carbon units) per square meter per day (for fertilized pasture) and 6.3 milligrams per square meter per day (for unfertilized pasture), with uptake from fertilized wheat and maize fields ranging from 0.2 to 0.9 milligrams per square meter. ${ }^{227}$ This study implies that an additional 0.6 to 6.1 milligrams of methane per square meter per day would be absorbed by abandoned farmland, equivalent to 118.1 to $1,201.1$ grams per acre per year. Applying these figures to the 35 million acres of cropland idled between 1982 and 1992 implies an increase in methane uptake of 4,133 to 42,038 metric tons per year from this source.

${ }^{227}$ A. Mosier and D. Schimel, "Influence of Agricultural Nitrogen on Atmospheric Methane and Nitrous Oxide," Chemistry \&' Industry, Vol. 2 (December 1991), p. 875. 


\section{Appendix E \\ Common Conversion Factors}

\section{Permutations of SI Units}

$1 \mathrm{gC}=1$ gram carbon $(\mathrm{C})$

$1 \mathrm{GgC}=$ gigagram carbon $(C)=1,000$ metric tons carbon (C)

$1 \mathrm{TgC}=1$ teragram carbon $(\mathrm{C})=1$ million metric tons carbon (C)

$1 \mathrm{PgC}=1$ petagram carbon $(\mathrm{C})=1$ billion metric tons carbon (C)

1 ppmv = 1 part per million by volume in the atmosphere

$1 \mathrm{ppbv}=1$ part per billion by volume in the atmosphere

$1 \mathrm{pptv}=1$ part per trillion by volume in the atmosphere

\section{Density}

1 thousand cubic feet of methane $=42.28$ pounds

1 thousand cubic feet carbon dioxide $=115.97$ pounds

1 metric ton natural gas liquids $=11.6$ barrels

1 metric ton unfinished oils $=7.46$ barrels

1 metric ton alcohol $=7.94$ barrels

1 metric ton liquefied petroleum gas $=11.6$ barrels

1 metric ton aviation gasoline $=8.9$ barrels

1 metric ton naphtha jet fuel $=8.27$ barrels

1 metric ton kerosene jet fuel $=7.93$ barrels

1 metric ton motor gasoline $=8.53$ barrels

1 metric ton kerosene $=7.73$ barrels

1 metric ton naphtha $=8.22$ barrels

1 metric ton distillate $=7.46$ barrels

1 metric ton residual oil $=6.66$ barrels

1 metric ton lubricants $=7.06$ barrels

1 metric ton bitumen $=6.06$ barrels

1 metric ton waxes $=7.87$ barrels

1 metric ton petroleum coke $=5.51$ barrels

1 metric ton petrochemical feedstocks $=7.46$ barrels

1 metric ton special naphtha $=8.53$ barrels

1 metric ton miscellaneous products $=8.00$ barrels

\section{Alternative Measures of Greenhouse Gases}

1 pound methane, measured in carbon units $\left(\mathrm{CH}_{4}-\mathrm{C}\right)$ $=1.333$ pounds methane, measured at full molecular weight $\left(\mathrm{CH}_{4}\right)$

1 pound carbon dioxide, measured in carbon units $\left(\mathrm{CO}_{2}-\mathrm{C}\right)=3.6667$ pounds carbon dioxide, measured at full molecular weight $\left(\mathrm{CO}_{2}\right)$

1 pound carbon monoxide, measured in carbon units $(\mathrm{CO}-\mathrm{C})=2.333$ pounds carbon monoxide, measured at full molecular weight (CO)

1 pound nitrous oxide, measured in nitrogen units $\left(\mathrm{N}_{2} \mathrm{O}-\mathrm{N}\right)=1.571$ pounds nitrous oxide, measured at full molecular weight $\left(\mathrm{N}_{2} \mathrm{O}\right)$

\section{Weight}

1 kilogram $=2.205$ pounds

1 short ton $=0.9072$ metric tons

1 metric ton $=1.1023$ short tons $=2,204.6$ pounds

1 cubic meter $=35.3147$ cubic feet

1 cubic centimeter $=3.531 \times 10^{-5}$ cubic feet

\section{Area}

1 acre $=0.40468724$ hectare $($ ha $)=4,047 \mathrm{~m}^{2}$

1 hectare (ha) $=10,000 \mathrm{~m}^{2}=2.47$ acres

1 kilometer $=0.6214$ miles

\section{Energy}

1 joule $=947.9 \times 10^{-21}$ quadrillion Btu

1 exajoule $=10^{18}$ joules $=0.9479$ quadrillion Btu

1 quadrillion Btu $=1.0551$ exajoule 


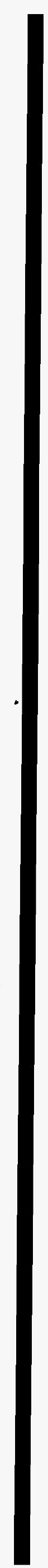




\section{References}

Abrahamson, D. "Aluminum and Global Warming." Nature 356. (April 1992). 454.

Alternative Fluorocarbons Environmental Acceptability Study. Historic Production, Sales and Atmospheric Release of HCFC-142b. (Washington, DC, February 1994).

Alternative Fluorocarbons Environmental Acceptability Study. Production, Sales and Atmospheric Release of Fluorocarbons Through 1994. (Washington, DC, October 1995).

American Automobile Manufacturers Association. AAMA Vehicle Facts and Figures. (Detroit, MI, various years).

American Gas Association. Gas Engineers Handbook: Fuel Gas Engineering Practices. (New York, NY: Industrial Press, 1974).

American Gas Association. Gas Facts. Annual Statistical Report. (Washington, DC, various years).

American Iron and Steel Institute. Iron and Steel Annual Statistical Report. (Washington, DC, various years).

American Petroleum Institute. Basic Petroleum Data Book. (Washington, DC, various years).

American Society of Agricultural Engineers. Manure Production and Characteristics Standards. (St. Joseph, MI, 1988).

American Society for Testing and Materials. ASTM and Other Specifications for Petroleum Products and Lubricants. (Philadelphia, PA, 1985).

Association of American Plant Food Control Officials, Commercial Fertilizers 1995 (Lexington, KY 1996).

Augenstein, D. "The Greenhouse Effect and U.S. Landfill Methane." Global Environmental Change. (December 1992). 311-328.

Baldwin, R.L., Thornley, J.H.M., and Beever, D.E. "Metabolism of the Lactating Cow: Digestive Elements of a Mechanistic Model." Journal of Dairy Research 54. (1987). 107-131.

Barnard, G. "Use of Agricultural Residues as Fuel." Bioenergy and the Environment Ed. J. Pasztor and L. Kristoferson. (Boulder, CO: Westview Press, 1990).
Barnes, D.W., and Edmonds, J.A. An Evaluation of the Relationship Between the Production and Use of Energy and Atmospheric Methane Emissions. DOE/NBB-0088P. (Washington, DC, U.S. Department of Energy, 1990).

Bartlett, K., and Harriss, R.C. "Review and Assessment of Methane Emissions from Wetlands." Chemosphere Vol 26, Nos 1-4. (1993).

Bell, J.F., and Linden, H.R. In American Gas Association, Gas Engineers Handbook (New York, NY: Industrial Press, 1974).

Berdowski, J.J.M., Beck, L., Piccot, S., Olivier, G.J., and Veldt, C. "Working Group Report: Methane Emissions from Fuel Combustion and Industrial Processes." Proceeding of an International IPCC Workshop on Methane and Nitrous Oxide: Methods in National Emissions Inventories and Options for Control. Ed. A.R. van Amstel. RIVM Report no. 481507003. (Bilthoven, The Netherlands, 1993).

Berry, J.T., et al., (Reports for 1986-1991, 1993-1994). Commercial Fertilizers. Tennessee Valley Authority, Fertilizer Research Center. (Muscle Shoals, Alabama).

Bingemer, H.G., and Crutzen, P.J. "The Production of Methane from Solid Wastes." Journal of Geophysical Research 92, D2. (February 20, 1987). 2181-2187.

Biocycle, "Nationwide Survey: The State of Garbage in America." (various years).

Birdsey, R.A. Carbon Storage and Accumulation in United States Forest Ecosystems. U.S. Forest Service General Technical Report WO-59. (Washington, DC, 1992).

Birdsey, R.A. "Changes in Forest Carbon Storage from Increasing Forest Area and Timber Growth," in R.N. Sampson and D. Hair, eds., Forests and Global Change, Vol 1: Opportunities for Increasing Forest Cover, (Washington, DC: American Forests, 1992).

Birdsey, R.A. and L.S. Heath, "Carbon Changes in U.S. Forests" in L.A. Joyce (ed)., Productivity of America's Forests and Climate Change (Fort Collins, CO: USDA Forest Service. General Technical Report. RM-GTR-271, 1995).

Blaxter, K.L., and Clapperton, J.L. "Prediction of the Amount of Methane Produced by Ruminants." British Journal of Nutrition 19. (1965). 511-522. 
Bodanzky, D. "Prologue to the Climate Convention." Negotiating Climate Change: The Inside Story of the Rio Convention Ed. I. Minter and J.A. Leonard. (Cambridge, UK: Cambridge University Press, 1994). 49-66.

Boden, T.A., Stepanski, R.J., and Stoss, F.W. Trends '91: A Compendium of Data on Global Change. ORNL/CDIAC46. (Oak Ridge, TN: Oak Ridge National Laboratory, December 1991).

Boden, T.A., Kaiser, D., Stepanski, R.J., and Stoss, F.W. Trends '93: A Compendium of Data on Global Change. ORNL/CDIAC-65. (Oak Ridge, TN: Oak Ridge National Laboratory, September 1994).

Bogner, J.E. "Anaerobic Burial of Refuse in Landfills: Increased Atmospheric Methane and Implications for Increased Carbon Storage." Ecological Bulletins 42. (1992). 98-108.

Bouwman, A.F. "Exchange of Greenhouse Gases Between Terrestrial Ecosystems and Atmosphere." Soils and the Greenhouse Effect. Ed. A.F. Bouwman. (New York, NY: John Wiley and Sons, 1990). 61-127.

Bremner, J.M., and Blackmer, A.M. "Nitrous Oxide: Emissions from Soil during Nitrification of Fertilizer Nitrogen." Science 199. (1978). 295-296.

Burdick, D.L., and Leffler, W.L. Petrochemicals in Nontechnical Language. (Pennwell Publishing Company, 1990).

Chemical and Engineering News. Annual report on "Top 50 Industrial Chemicals." (April issue, various years).

Chemical Manufacturers Association, Inc. U.S. Chemical Industry Statistical Handbook. (Washington, DC, various years).

Chemical Week, "DuPont Acts to Cut Perfluoroethane." (August 23, 1995), p. 34.

Cicerone, R.J., and Shetter, J.D. "Sources of Atmospheric Methane: Measurements in Rice Paddies and Discussion." Journal of Geophysical Research 86, C8. (August 1981). 7,203-7,209.

Cicerone, R.J., Shetter, J.D., and Delwiche, C.C. "Seasonal Variation of Methane Flux from a California Rice Paddy." Journal of Geophysical Research 88. (December 1983).

Clean Air Act Amendments of 1990. (P.L. 101-549, Nov. 15, 1990), Title VI, "Stratospheric Ozone Protection," 10489AT2849-2872.

Clinton, W.J., and Gore, A. The President's Climate Change Action Plan. (Washington, DC, October 1994). Available through the U.S. Department of Energy Office of Public Information and on the internet at: http:// gcrio.gcrio.org/USCCAP/toc.html.
Cost, N.D., J. Howard, B. Mead, W.H. McWilliams, W.B. Smith, D.D. Van Hooser, and E.H. Wharton. The Biomass Resource of the United States, USDA Forest Service General Technical Report WO-57. 1990.

Crutzen, P.J., Aselmann, I., and Seiler, W. "Methane Production by Domestic Animals, Wild Ruminants, Other Herbivorous Fauna, and Humans." Tellus 38B, 34. (1986). 271-284.

Cubbage, F.C. "Federal Land Conversion Programs." Forests and Global Change, Vol. 1. (Washington, DC, 1992). 184.

Dahl, T. Wetlands Losses in the United States: 1780's to 1980's. (Washington, DC, U.S. Department of the Interior, Fish and Wildlife Service, 1990).

Dale, C., et al. "First Oxygenated Gasoline Season Shakes Out Differently Than Expected." Oil and Gas Journal. (October 25, 1993).

Darley, E. Emission Factors from Burning Agricultural Wastes Collected in California. Final Report, CAL/ARB Project 4-011. (Riverside, CA: University of California, 1977).

Daugherty, A. Major Uses of Land in the United States: 1987. Agricultural Economic Report No. 643. (Washington, DC, U.S. Department of Agriculture, Economic Research Service, 1991).

Daugherty, A. Major Uses of Land in the United States: 1992. Agricultural Economic Report Number 723 (Washington, DC September 1995).

Davis, S.C., and Strang, S.G. Transportation Energy Data Book: Edition 13, ORNL-6743. (Oak Ridge, TN: Oak Ridge National Laboratory, Center for Transportation Analysis, March 1993).

Davis, S.C., and Strang, S.G. Transportation Energy Data Book: Edition 14. ORNL-6743. (Oak Ridge, TN: Oak Ridge National Laboratory, Center for Transportation Analysis, March 1994).

Defense Logistics Agency, Defense Fuel Supply Center, Office of the Comptroller. Fact Book Annual Report. (Alexandria, VA, various years).

DeLuchi, M. Emissions of Greenhouse Gases from the Use of Transportation Fuels and Electricity. Vol. 2. ANL/ ESD/TM-22. (Chicago, IL: Argonne National Laboratory, November 1993).

De Soete, G.G. "Nitrous Oxide from Combustion and Industry: Chemistry, Emissions and Control." International IPCC Workshop Proceedings: Methane and Nitrous Oxide, Methods in National Emissions Inventories and Options for Control. Ed. A.R. van Amstel. (Bilthoven, Netherlands: RIVM, 1993). 287-337. 
Douglas, H. Handbook of Mineral Economics. (San Francisco, CA: Hugh Douglas and Company, 1983). 46.

Duxbury, J.M., and McConnaughey. P.K. "Effect of Fertilizer Source on Denitrification and Nitrous Oxide Emission in A Maize Field." Soil Sci. Soc. Am. J. 50. (1986). 644-648.

E.H. Pecham and Associates, Inc. The Emission Reduction and Cost Analysis Model for $\mathrm{NO}_{\mathrm{X}}\left(E R C A M-N O_{X}\right)$. Report prepared for the U.S. Environmental Protection Agency, Ozone/CO Programs Branch (Research Triangle Park, NC, May 1994).

Eberle, A.C. "An Engineering Estimate of the Incremental Change in Methane Emissions with Increasing Throughput in a Natural Gas System." Presented at the 1994 International Workshop on Environmental and Economic Impacts of Natural Gas Losses, March 22 and 23, Prague, The Czech Republic.

Energy Information Administration. Annual Energy Review. DOE/EIA-0384. (Washington, DC, various years).

Energy Information Administration. Annual Energy Outlook 1996. DOE/EIA-0383(96). (Washington, DC, January 1996).

Energy Information Administration. Btu Tax on Finished Petroleum Products. Unpublished Report. (Washington, DC, April 1993).

Energy Information Administration. Coal Industry Annual 1993. DOE/EIA-0584(93). (Washington, DC, December 1994).

Energy Information Administration. Coal Production. DOE/EIA-0118. (Washington, DC, various years).

Energy Information Administration. Cost and Quality of Fuels for Electric Utility Plants 1991. DOE/EIA-0191(91). (Washington, DC, August 1992).

Energy Information Administration. Electric Power Annual 1993. DOE/EIA-0348(93). (Washington, DC, 1994).

Energy Information Administration. Emissions of Greenhouse Gases in the United States 1985-1990. DOE/ELA0573. (Washington, DC, September 1993).

Energy Information Administration. Emissions of Greenhouse Gases in the United States 1987-1992. DOE/EIA0573. (Washington, DC, November 1994).

Energy Information Administration. Emissions of Greenhouse Gases in the United States 1987-1994. DOE/EIA0573(87-94). (Washington, DC, October 1995).
Energy Information Administration. Fuel Oil and Kerosene Sales. DOE/EIA-0535. (Washington, DC, various years).

Energy Information Administration. Household Vehicles Energy Consumption. DOE/EIA-0464. (Washington, DC, various years).

Energy Information Administration. International Energy Annual. DOE/ELA-0121. (Washington, DC, various years).

Energy Information Administration. International Energy Outlook 1996. DOE/EIA-0484(96). (Washington, DC, January 1996); available on the internet at http:// www.eia.doe.gov/oiaf/ieo96/front.html.

Energy Information Administration. Manufacturing Energy Consumption Survey. DOE/EIA-0512. (Washington, DC, various years).

Energy Information Administration. Monthly Energy Review. DOE/EIA-0035. (Washington, DC, various issues).

Energy Information Administration. Natural Gas Annual. DOE/EIA-0131. (Washington, DC, various years).

Energy Information Administration. Natural Gas Monthly. DOE/EIA-0130. (Washington, DC, various issues).

Energy Information Administration. Petroleum Supply Annual. DOE/EIA-0340. (Washington, DC, various years).

Energy Information Administration. "Residential Transportation Energy Consumption Surveys (RTECS)" (Washington, DC, various issues).

Energy Information Administration. Short-Term Energy Outlook. DOE/EIA-0202. (Washington, DC, various issues).

Energy Information Administration. State Energy Data Report: Consumption Estimates. DOE/EIA-0214. (Washington, $\mathrm{DC}$, various years).

Energy Information Administration, unpublished survey data, Form EIA-767, Steam Electric Plant Operation and Design Report (Washington, DC, various years).

Energy Information Administration. U.S. Electric Utility Demand Side Management 1994. DOE/EIA-0589(94). (Washington, DC, December 1995).

Finfinger, G., U.S. Department of the Interior, Bureau of Mines, Pittsburgh Research Center.

Franklin Associates, Ltd. Characterization of Municipal Solid Waste in the United States: Annual Updates. (Prepared for U.S. Environmental Protection Agency, Office of Solid Waste and Emergency Response, various years). 
Freedonia Group Inc. Carbon Dioxide. Business Research Report B286. (Cleveland, OH, November 1991).

Freedonia Group Inc. Carbon Dioxide. Industry Study 564. (Cleveland, OH, February 1994).

Goodger, E.M. Hydrocarbon Fuels: Production, Properties and Performance of Liquids and Gases. (New York, NY: John Wiley \& Sons, 1975). 43.

Greeley, W., U.S. Forest Service, "The Relation of Geography to Timber Supply," Economic Geography, Vol 1 (1925).

Griffin, R. " $\mathrm{CO}_{2}$ Release from Cement Production 19501985." Estimates of $\mathrm{CO}_{2}$ Emissions from Fossil Fuel Burning and Cement Manufacturing, Based on the United Nations Estimates and U.S. Bureau of Mines Cement Manufacturing Data. Ed. Gregg Marland et al. (Oak Ridge, TN, Oak Ridge National Laboratory, 1987).

Grubb, M.J. "On Coefficients for Determining Greenhouse Gas Emissions from Fossil Fuel Production and Consumption." Royal Institute of International Affairs, Energy and Environmental Programme. (London, April 1989).

Guerra, C.R., Kelton, K., and Nielsen, D.C. "Natural Gas Supplementation with Refinery Gases and Hydrogen." In Institute of Gas Technology, New Fuels and Advances in Combustion Technologies. (Chicago, IL, June 1979).

Gunnerson, C.G., and Stuckey, D.C. Integrated Resource Recovery: Anaerobic Digestion: Principles and Practices for Biogas System, World Bank Technical Paper.

Guthrie, V.B. Ed. Petroleum Products Handbook. (New York, NY: McGraw-Hill, 1960).

Hadaller, O.J., and Momenthy, A.M. The Characteristics of Future Fuels, Part 1, "Conventional Jet Fuels." (Seattle, WA: Boeing Corp., September 1990).

Harrison, M. R. and R. M. Cowgill, Tier 2 Summary of Methane Emissions from the Natural Gas Industry, Draft Final Report Prepared for the Gas Research Institute and the U.S. Environmental Protection Agency (Washington, D.C. January 1996).

Hashimoto, A.G., Varel, V.H., and Chen, Y.R. "Ultimate Methane Yield from Beef Cattle Manure; Effect of Temperature, Ration Constituents, Antibiotics and Manure Age." Agricultural Wastes 3. (1981). 241-256.

Heath, L.S., R.A. Birdsey, and C. Row, "Carbon Pools and Flux in U.S. Forest Products," in The Role of Forest Ecosystems and Forest Resource Management in the Global Carbon Cycle. NATO ASI Series, Germany: SpringerVerlag, 1995.
Hill, D.T. "Methane Productivity of the Major Animal Types." Transactions of the ASAE 27, 2. (1984). 530-540.

Holzappfel-Pschorn, A., and Seiler, W. "Methane Emission During a Cultivation Period from an Italian Rice Paddy." Journal of Geophysical Research 91, D11. (October 1986). 11,803-11,814.

Hong, B.D., and Slatick, E.R. "Carbon Dioxide Emission Factors for Coal." Quarterly Coal Report, January-March 1994. 7.

Houghton, R.A., et al. "The Flux of Carbon from Terrestrial Ecosystems to the Atmosphere in 1980 Due to Changes in Land Use: Geographic Distribution of the Global Flux." Tellus 39. (1987). 124.

Hunt, J.M. Petroleum Geochemistry and Geology. (San Francisco, CA: W.H. Freeman, 1979).

Intergovernmental Panel on Climate Change. Climate Change 1992: The Supplementary Report to the IPCC Scientific Assessment. (Cambridge, UK: Cambridge University Press, 1992).

Intergovernmental Panel on Climate Change. Climate Change 1994: Radiative Forcing of Climate Change. (Cambridge, UK: Cambridge University Press, 1995).

Intergovernmental Panel on Climate Change. Climate Change 1995: The Science of Climate Change. (Cambridge, UK: Cambridge University Press, 1996). Summary available on the Internet at http://www.unep.ch/ipcc/ ipcc95.html

Intergovernmental Panel on Climate Change. Climate Change: The IPCC Scientific Assessment. (Cambridge, UK: Cambridge University Press, 1990).

Intergovernmental Panel on Climate Change. IPCC Guidelines for National Greenhouse Gas Inventories. Vols. 1-4. (Paris, France, 1994-95).

Intergovernmental Panel on Climate Change. Methane and Nitrous Oxide, Methods in National Emissions Inventories and Options for Control. Proceedings, Research for Man and Environment. (Bilthoven, Netherlands, February 1993).

Keeling, C.D., and Whorf, T.P. "Atmospheric $\mathrm{CO}_{2}$ Records from Sites in the SIO Air Sampling Network." (1993).

Kirchgessner, D., Cowgill, R.M., Harrison, M., and Campbell, L.M. "Methods for Estimating Methane Emissions from the Domestic Natural Gas Industry." Presented at the 1995 Greenhouse Gas Emissions and Mitigation Research Symposium. (U.S. Environmental Protection Agency, National Risk Management Research Laboratory, Air Pollution Prevention Division, June 1995). 
Kirchgessner, D.A., Piccot, S.D., and Chadha, A. "Estimation of Methane Emissions from A Surface Coal Mine Using Open-Path FTIR Spectroscopy and Modeling Techniques." Chemosphere. (Special Methane Edition, 1993).

Ko, M.K.W., Sze, N.D., Wang, W.C., Shia, G., Goldman, A., Murcray, F.J., Murcray, D.G., and Rinsland, C.P. "Atmospheric Sulfur Hexafluoride: Sources, Sinks, and Greenhouse Warming." Journal of Geophysical Research 98. 10,500 .

Kostick, D. "Soda Ash, Sodium Bicarbonate, and Sodium Sulfate." Mineral Facts and Problems. 1985 ed. (Washington, DC, 1985). 843.

Kostick, D. "Sodium Compounds," Minerals Yearbook, 1987. (Washington, DC, 1987). 795-801.

Kramlich, J.C., and Linak, W.P. "Nitrous Oxide Behavior in the Atmosphere, and in Combustion and Industrial Systems." Progress in Energy and Combustion Science 20. (1994). 196.

Landau, C.W., and Bolich, P.K. "Methane Emissions from Louisiana First and Ratoon Crop." Soil Science 156. (1993). 42-48.

Leutwyler, K. "No Global Warming?" Scientific American. (February 1994). 24.

Li, C., Frolking, S., and Harriss, R: "Modeling Carbon Biogeochemistry in Agricultural Soils." Global Biogeochemical Cycles 8. (September 1994).

Liss, W.E., et al. Variability of Natural Gas Composition in Select Major Metropolitan Areas of the United States. GRI92/0123. (Chicago, Gas Research Institute, October 1992).

Mann, L.K. "Changes in Soil Carbon Storage After Cultivation." Soil Science 142, 5. (November 1986). 279.

Mannsville Chemical Corporation. "Adipic Acid." Chemical Products Synopsis. (Asbury Park, NJ: June 1990).

ManTech Environmental Technology, Inc. Impact of Conservation Tillage on Soil and Atmospheric Carbon in the Contiguous United States, PB92-113448, prepared for the Corvallis Environmental Research Laboratory, U.S. Environmental Protection Agency. (September 1991).

Marland, G., and Rotty, R. "Carbon Dioxide Emissions from Fossil Fuels: A Procedure for Estimation and Results for 1950-1982." Tellus 36B. (1984). 232-261.

Marland, G., et al. Estimates of $\mathrm{CO}_{2}$ Emissions from Fossil Fuel Burning and Cement Manufacturing, Based on the United Nations Energy Statistics and the U.S. Bureau of Mines Cement Manufacturing Data. (Oak Ridge, TN, Oak Ridge National Laboratory, 1989).
Marland, G., and Pippin, A. "United States Emissions of Carbon Dioxide to the Earth's Atmosphere by Economic Activity." Energy Systems and Policy 14, 4. (1990). 319-336.

Martel, C.R., and Angelo, L.C. "Hydrogen Content as a Measure of the Combustion Performance of Hydrocarbon Fuels." Current Research in Petroleum Fuels I. (New York, NY: MSS Information Corporation, 1977).

Matthews, E., and Fung, I. "Methane Emissions from Natural Wetlands: Global Distribution, Area, and Environmental Characteristics." Global Biogeochemical Cycles Vol 1. No. 1. (March 1987).

Matthews, E., Fung, I., and Lerner, J. "Methane Emission from Rice Cultivation: Geographic and Seasonal Distribution of Cultivated Areas and Emissions." Global Biogeochemical Cycles 5, 1. (March 1991). 10.

Mosier, A. "Nitrous Oxide Emissions from Agricultural Soils." paper presented at RIVM International Workshop on Methane and Nitrous Oxide: Methods in National Emission Inventories and Options for Control (Amersfoort, The Netherlands, February 3-5, 1993.

Mosier, A., and Schimel, D., "Influence of Agricultural Nitrogen on Atmospheric Methane and Nitrous Oxide." Chemistry \& Industry 2. (December 1991). 875.

Mosier, A., et al. "Methane and Nitrous Oxide Fluxes in Native, Fertilized, and Cultivated Grasslands." Nature Vol 350, No. 6316. (March 28, 1991). 330-332.

Mosier, A.R., Parton, W.J., and Hutchinson, G.L. "Modelling Nitrous Oxide Evolution from Cropped and Native Soils." Ecol. Bulletin 35. (1983). 229-241.

Nagy, B., and Columbo, U., Eds. Fundamental Aspects of Petroleum Chemistry. (New York, NY: Elsevier Publishing, 1967).

National Institute of Petroleum and Energy Research. Motor Gasoline, Summer, and Motor Gasoline, Winter. (1984-1994).

National Research Council. Rethinking the Ozone Problem in Urban and Regional Air Pollution. (Washington, DC: National Academy Press, 1991).

Neue, H.H., and Scharpenseel, H.W. Gaseous Products of Decomposition of Organic Matter and Rice. (Los Banos, Philippines, 1984).

Oak Ridge National Laboratory. Transportation Energy Data Book. (Oak Ridge, TN, various years).

Organization for Economic Cooperation and Development. Estimation of Greenhouse Gas Emissions and Sinks. (Final Report). (Paris, France, August 1991). 
Ozone Depletion Online Today, "DuPont Set to Expand Markets for Ozone-Safe HFC-152a Product." (Alexandria, VA, June 9, 1995).

Pacey, J. "Methane Recovery from Landfills," presented at the 1995 Greenhouse Gas emissions and Mitigation Research Symposium, Washington, DC (June 27-29, 1995).

Pacey, J., Thorneloe, S.A., and Dórne, M. "Methane Recovery from Landfills and an Overview of EPA's Research Program for Landfill Gas Utilization." Presented at the 1995 Greenhouse Gas Emissions and Mitigation Research Symposium, U.S. Environmental Protection Agency. (Washington, DC, June 27-29, 1995).

Parson, E.A., and Greene, O. "The Complex Chemistry of the International Ozone Agreements." Environment 37, No. 2. (March 1995). 21.

Piccot, S.D., Masemore, S.S., Ringler, E., and Kirchgessner, D.A. "Developing Improved Methane Emission Estimates for Coal Mining Operations." Presented at the 1995 Greenhouse Gas Emissions and Mitigation Research Symposium. (U.S. Environmental Protection Agency, June 27-29, 1995).

Powell, D. S., J. L. Faulkner, D. R. Darr, Z. Zhu and D. W. MacCleery, Forest Resources of the United States, 1992 USDA Forest Service General Technical Report RM-234. (September 1993).

Prather, M., et al. "Other Trace Gases and Atmospheric Chemistry." Intergovernmental Panel on Climate Change. Climate Change 1994: Radiative Forcing of Climate Change. (Cambridge, UK: Cambridge University Press, 1995).

Radian Corporation. Global Emissions of Methane from Petroleum Sources. Report prepared for the American Petroleum Institute. .(Research Triangle Park, NC, February 1992).

Radian Corporation. Methane Emissions from Petroleum Production. (Research Triangle Park, NC, 1992).

Radian Corporation. Nitrous Oxide Emissions from Adipic Acid Manufacturing. Final Report prepared for U.S. Environmental Protection Agency, Office of Research and Development. (Rochester, NY, January 1992).

Railroad Commission of Texas. Annual Summaries of Texas Natural Gas. (various years).

Reimer, R.A., Parrett, R.A., and Slaten, C.S., "Abatement of $\mathrm{N}_{2} \mathrm{O}$ Emissions Produced in Adipic Acid," Proceedings of the 5th International Workshop on Nitrous Oxide Emissions. (Tsukuba, Japan, July 1992).
Rhodes, A.K. "U.S. Refiners Scramble To Meet Reformulated Gasoline Mandate." Oil and Gas Joumal. (January 27, 1992).

Ringen, S., Lanum, J., and Miknis, F.P. "Calculating Heating Values from Elemental Compositions of Fossil Fuels." Fuel 58. (January 1979). 69.

Rose, J.W., and Cooper, J.R. Technical Data on Fuel. The British National Committee, World Energy Conference, London, England. (1977).

Safley, L.M., Casada, M.E., Woodbury, J., and Roos, K.F. Global Methane Emissions from Livestock and Poultry Manure. EPA/400/1-91/048. (Washington, DC, U.S. Environmental Protection Agency, Office of Air and Radiation, February 1992).

Salthouse, R. Making Clean Gasoline. (Logistics Manägement Institute, September 1992).

Sampson, R.N., and Winnett, S.M. "Trees, Forests, and Carbon." Forests and Global Change, Vol. 1. (Washington, DC, 1992). 44.

Sass, R.L., Fisher, F.M., and Harcombe, P.A. "Methane Production and Emission in a Texas Rice Field." Global Biogeochemical Cycles 4, 1. (March 1990). 47-68.

Sass, R., Fisher, F., Lewis, S., Júnd, M., and Turner, F. "Methane Emissions from Rice Fields: Effect of Soil Properties." Global Biogeochemical Cycles 8. (1994). 135.

Sass, R.L., Fisher, F.M., and Wang, Y.B. "Methane Emissions from Rice Fields: The Effect of Floodwater Management." Global Biogeochemical Cycles 6. (1992). 249262.

Schlesinger, W.H. "Changes in Soil Carbon Storage and Associated Properties with Disturbance and Recovery." The Changing Carbon Cycle: A Global Analysis. Ed. J. Trabalka and D. Riechle. (New York: Springer-Verlag, 1986).

Schmidt, Paul F. Fuel Oil Manual. (New York: Industrial Press, Inc., 1969).

Schutz, H., Seiler, W., and Conrad, R. "Processes Involved in Formation and Emissions of Methane in Rice Paddies." Biogeochemistry 7. (1989). 33-53.

Science Applications International Corporation. Analysis of the Relationship Between the Heat and Carbon Content of U.S. Fuels: Final Task Report. Report prepared for Energy Information Administration, Office of Coal, Nuclear, Electric, and Alternate Fuels. (Washington, DC, 1992).

Searls, J.P. "Sodium Compounds," Minerals Yearbook, 1984. U.S. Bureau of Mines. (Washington, DC: 1984). 839-845. 
Seiler, W., and Crutzen, P. "Estimates of Gross and Net Fluxes of Carbon Between the Biosphere and the Atmosphere from Biomass Burning." Climatic Change 2. (1980).

Shine, K.P., Fouquart, Y., Ramaswamy, V., Solomon, S., and Srinivasan, J. "Radiative Forcing," Climate Change 1994: Radiative Forcing of Climate Change. (Cambridge, UK: Cambridge University Press, 1995). 177.

Spicer, C.W., Holdren, M.W., Smith, D.L., Hughes, D.P., and Smith, M.D. "Chemical Composition of Exhaust from Aircraft Turbine Engines." Journal of Engineering for Gas Turbines and Power, 114. (January 1992). 111-117.

Steudler, P.A., et al. "Influence of Nitrogen Fertilization on Methane Uptake in Temperate Forest Soils." Nature 341. (September 28, 1989). 314-315.

Stevens, W.R., III. Abatement of Nitrous Oxide Emissions Produced in the Adipic Acid Industry. White House Conference on Global Climate Change, Nitrous Oxide Workshop. (Mimeo, The DuPont Company, Wilmington, DE, June 11, 1993).

Strehler, A., and Stutzle, W. "Biomass Residues." Biomass: Regenerable Energy Ed. D.O. Hall and R.P. Overend. (Chichester, UK: John Wiley and Sons, 1987). 85.

Takeshita, M., and Soud, H. IEA Coal Research. FGD Performance and Experience on Coal-fired Plants. (London, England, July 1993).

Tennessee Valley Authority, National Fertilizer and Environmental Research Center. Commercial Fertilizers (Including Fertilizer Use by Class). (Muscle Shoals, AL, 1986-1994).

Thiemens, M., and Trogler, W. "Nylon Production: An Unknown Source of Atmospheric Nitrous Oxide." Science 251. (February 22, 1991). 932-934.

Thorneloe, S.A. "Landfill Gas Recovery/ Utilization-Options and Economics." Presented at the Sixteenth Annual Conference by the Institute of Gas Technology on Energy from Biomass and Wastes, Orlando, FL, March 5, 1992.

Thorneloe, S.A., Doorn, M.R.J., Stefanski, L.A., Barlaz, M.A., Peer, R.L., and Epperson, D.L. "Estimate of Methane Emissions from U.S. Landfills." Prepared for U.S. Environmental Protection Agency, Office of Research and Development. (April 1994).

Trevits, M.A., Finfinger, G.L., and LaScola, J.C. "Evaluation of U.S. Coal Mine Emissions." Society for Mining, Metallurgy and Exploration, Proceedings of the Fifth U.S. Mine Ventilation Symposium. (Littlejohn, 1991).
Turner, D.P., Lee, J.L., Koerper, G.J., and Barker, J.R., Eds. The Forest Sector Carbon Budget of the United States:

- Carbon Pools and Flux under Alternative Policy Options. EPA/600/3-93/093. (Washington, DC: U.S. Environmental Protection Agency, Office of Research and Development, May 1993).

United Nations. "Report of the Intergovernmental Negotiating Committee for a Framework on Convention on Climate Change on the Work of the Second Part of Its Fifth Session, Held at New York from 30 April to 9 May 1992." UN Document A/AC.237/18, Part II. (May 15, 1992).

United Nations Environment Program, Report of the Conference of the Parties on its First Session, Held at Berlin from 28 March to 7 April 1995, (Addendum) Part Two: Action Taken by the Conference of the Parties at its First Session (FCCC/CP/1995/7/Add.1)(6 June 1995).

United Nations, Framework Convention on Climate Change, Review of the Implementation of the Convention and of Decisions of the First Session of the Conference of the Parties: Ministerial Declaration (FCCC/CP/1996/L.17)(18 July 1996).

U.S. Department of Agriculture, Crop Reporting Board, Statistical Reporting Service. Commercial Fertilizers. $\mathrm{SpCr}$ 7. (Washington, DC, various years).

U.S. Department of Agriculture, Forest Service, AVHRR Forest Type Map, 1993 RPA Program, Forest Inventory and Analysis (Starkville, MS, December 1992), modified for printing by Pacific Meridian Resources (Emeryville, CA, 1996).

U.S. Department of Agriculture, Internet Site @gopher. usda.mannlib.cornell.edu.

U.S. Department of Agriculture, National Agricultural Statistics Service, Livestock, Dairy, and Poultry Branch. Cattle: Final Estimates, Sheep and Goats: Final Estimates, and Hogs and Pigs: Final Estimates. (Washington, DC, various years).

U.S. Department of Agriculture, National Agricultural Statistics Service. Crop Production. (Washington, DC, various years).

U.S. Department of Agriculture, Soil Conservation Service. 1991 Update of National Resources Inventory Wetlands Data for Non-Federal Rural Lands. (Washington, $\mathrm{DC}$, not dated).

U.S. Department of Agriculture, Soil Conservation Service. Summary Repart: 1992 National Resources Inventory. (Washington, DC, July 1994).

U.S. Department of Commerce, Bureau of the Census. 1990 Census of Population and Housing. Population and Housing Unit Counts, United States. 1993. CPH-2-1. 
U.S. Department of Commerce, Economics and Statistics Administration, Bureau of the Census. Census of Agriculture, United States Summary and State Data. Vol. 1, "Geographic Area Series," Part 51 (Washington, DC, 1982, 1987, and 1992).

U.S. Department of Commerce, Bureau of the Census. Current Industrial Reports: Annual Report on Fertilizer Materials. MA28B. (Washington, DC, 1992).

U.S. Department of Commerce, Bureau of the Census. "Industrial Gases." Current Industrial Reports. (Washington, DC).

U.S. Department of Commerce, Bureau of the Census. United States Census, 1980 and 1990.

U.S. Department of Commerce, National Bureau of Standards. Thermal Properties of Petroleum Products, Miscellaneous Publication No. 97. (Washington, DC, 1929).

U.S. Department of Energy. Atmospheric Carbon Dioxide and the Global Carbon Cycle. DOE/ER-0239. Ed. J.R. Trabalka. (Washington, DC, 1985).

U.S. Department of Energy. The Climate Change Action Plan: Technical Supplement. DOE/PO-0011. (Washington, DC, March 1994).

U.S. Department of Energy. Compliance Assessment of the Portsmouth Gaseous Diffusion Plant. DOE/EH-0144. (Washington, DC, April 1990).

U.S. Department of Energy. Energy Technology Characterizations Handbook: Environmental Pollution and Control Factors. Third Edition, DOE/EP-0093. (Washington, DC, March 1983).

U.S. Department of Energy. An Evaluation of the Relationship Between the Production and Use of Energy and Atmospheric Methane Emissions. DOE/NBB-0088P. (Washington, DC, April 1990).

U.S. Department of the Interior, Bureau of Mines. Aluminum Report. (Washington, DC, various years).

U.S. Department of the Interior, Bureau of Mines. Cement Annual Report. (Washington, DC, various years).

U.S. Department of the Interior, Bureau of Mines. Crushed Stone Annual Report. (Washington, DC, various years).

U.S. Department of the Interior, Bureau of Mines. Minerals Commodity Summaries. (Washington, DC, various years).

U.S. Department of the Interior, Bureau of Mines. Minerals Yearbook. (Washington, DC, various years).

U.S. Department of the Interior, Bureau of Mines. Soda Ash Annual Report. (Washington, DC, various years).
U.S. Department of the Interior, U.S. Geological Service, Office of Minerals, Faxback Service.

U.S. Department of State. National Action Plan for Global Climate Change. Publication 10026. (Washington, DC, December 1992).

U.S. Department of Transportation, Federal Highway Administration. Highway Statistics. (Washington, DC, various years).

U.S. Environmental Protection Agency. 1994 Toxics Release Inventory: Public Data Release. EPA-745-R-94-001 (Washington, DC, July 1996).

U.S. Environmental Protection Agency. Identifying Opportunities for Methane Recovery at U.S. Coal Mines: Draft Profiles of Selected Gassy Underground Coal Mines. (Washington, DC, September 1994).

U.S. Environmental Protection Agency. Regional Interim Emission Inventories (1987-1991), Volume I: Development Methodologies EPA-454-R-93-021a (Research Triangle Park, NC, May 1993).

U.S. Environmental Protection Agency, Environmental Research Laboratory. The Impact of Conservation Tillage Use on Soil and Atmospheric Carbon in the Contiguous United States. EPA/600/3-91/056. (Corvallis, OR, November 1991).

U.S. Environmental Protection Agency, Office of Air and Radiation. Anthropogenic Methane Emissions in the United States: Estimates for 1990. Report to Congress. Ed. Kathleen Hogan. (Washington, DC, April 1993).

U.S. Environmental Protection Agency, Office of Air and Radiation. Methane Emissions from Coal MiningIssues and Opportunities for Reduction. EPA/400/990/008. (Washington, DC, September 1990).

U.S. Environmental Protection Agency, Office of Air Quality Planning and Standards. Compilation of Air Pollutant Emission Factors. AP-42 Supplement D. (Research Triangle Park, NC, September 1995).

U.S. Environmental Protection Agency, Office of Air Quality Planning and Standards. National Air Pollutant Emission Trends 1900-1993. EPA-454/R-94-027. (Research Triangle Park, NC, October 1994).

U.S. Environmental Protection Agency, Office of Air Quality Planning and Standards. National Air Pollutant Emission Trends, Procedures Document, 1900-1993. EPA454/R-95-002. (Research Triangle Park, NC, December 1994).

U.S. Environmental Protection Agency, Office of Air Quality Planning and Standards. National Air Pollutant Emission Trends 1900-1994. EPA-454/R-95-011. (Research Triangle Park, NC, October 1995). 
U.S. Environmental Protection Agency, Office of Air Quality Planning and Standards. National Air Quality and Emissions Trends Report, 1992. (Research Triangle Park, NC, October 1993).

U.S. Environmental Protection Agency, Office of Air Quality Planning and Standards. National Air Pollutant Emissions Estimates 1940-1990. EPA-450/4-91-026. (Research Triangle Park, NC, November 1991).

U.S. Environmental Protection Agency, Office of Air Quality Planning and Standards. National Air Pollutant Emission Estimates 1980-1991. EPA-454/R-92-013. (Research Triangle Park, NC, October 1992).

U.S. Environmental Protection Agency, Office of Mobile Sources, User's Guide to MOBILE 5 (Mobile Source Emissions Model) (Ann Arbor, MI, 1993).

U.S. Environmental Protection Agency, Office of Policy, Planning and Evaluation. International Anthropogenic Methane Emissions: Estimates for 1990. EPA 230-R-93-010. (Washington, DC, January 1994).

U.S. Environmental Protection Agency, Office of Policy, Planning and Evaluation. Inventory of U.S. Greenhouse Gas Emissions and Sinks: 1990-1993. EPA 230-R-94-014. (Washington, DC, September 1994).
U.S. Environmental Protection Agency, Office of Policy, Planning and Evaluation. Inventory of U.S. Greenhouse Gas Emissions and Sinks: 1990-1994. EPA 230-R-96-006. (Washington, DC, November 1995).

U.S. Environmental Protection Agency, Office of Research and Development. The Forest Sector Carbon Budget of the United States: Carbon Pools and Flux Under Alternative Policy Options. EPA/600/3-93/093. (Washington, DC, May 1993).

U.S. International Trade Commission. Synthetic Organic Chemicals: United States Production and Trade. USITC Publication 2720. (Washington, DC, various years).

Waddle, K.L., D. Oswald, D. Daniel, Powell, and S. Douglas, Forest Statistics of the United States, 1987 USDA Forest Service Resource Bulletin PNW-RB-168, Pacific Northwest Research Station, Portland, OR, 1989.

Wassmann, R., Papen, H., and Rennenberg, H. "Methane Emissions from Rice Paddies and Possible Mitigation Strategies." Chemosphere 26. (1993). 201-217.

World Oil. Annual survey of State agencies. (February issue, various years).

Wuebbles, D.J., and Edmonds, J. Primer on Greenhouse Gases. (Chelsea, MI: Lewis Publishers, 1991). 


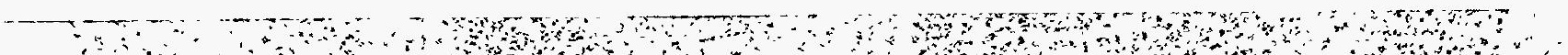




\section{Glossary}

Acid stabilization: A circumstance where the $\mathrm{pH}$ of the waste mixture in an animal manure management system is maintained near 7.0, optimal conditions for methane production.

Aerobic bacteria: Microorganisms living, active, or occurring only in the presence of oxygen.

Aerobic decomposition: The breakdown of a molecule into simpler molecules or atoms by microorganisms under favorable conditions of oxygenation.

Aerosols: Airborne particles.

Afforestation: Planting of new forests on lands that have not been recently forested.

Agglomerate: To gather into a ball, mass or cluster.

Agglomeration: The clustering of disparate elements.

Airshed: An area or region defined by settlement patterns or geology that results in discrete atmospheric conditions.

Albedo: The fraction of incident light or electromagnetic radiation that is reflected by a surface or body. See planetary albedo.

Anaerobes: Organisms that live and are active only in the absence of oxygen.

Anaerobic bacteria: Micro-organisms living, active, or occurring only in the absence of oxygen.

Anaerobic decomposition: The breakdown of molecules into simpler molecules or atoms by microorganisms that can survive in the partial or complete absence of oxygen.

Anaerobic lagoon: A liquid-based manure management system, characterized by waste residing in water to a depth of at least six feet for a period ranging between 30 and 200 days.

Anode: A positive electrode, as in a battery, radio tube, etc.

Anthracite: A hard, black, lustrous coal containing a high percentage of fixed carbon and a low percentage of volatile matter. Often referred to as hard coal.

Anthropogenic: Human made. Usually used in the context of emissions that are produced as the result of human activities.
API Gravity: A scale expressing the density of petroleum products as established by the American Petroleum Institute.

Asphalt: A dark-brown to black cement-like material obtained by petroleum processing, containing bitumens as the predominant constituents. Includes crude asphalt as well as the following finished products: cements, the asphalt content of emulsions (exclusive of water), and petroleum distillates blended with asphalt to make cutback asphalts.

Associated gas: Natural gas found mixed with crude oil in underground reservoirs, released as a byproduct of oil production.

Aviation gasoline: All special grades of gasoline for use in aviation reciprocating engines. Excludes blending components, which are blended or compounded into finished aviation gasoline.

Balancing item: A measurement of the difference between the reported amount of natural gas produced and the reported amount consumed.

Biofuels: Organic materials, such as wood, waste, and alcohol fuels, burned for energy purposes.

Biogas: The gas produced from the anaerobic decomposition of organic material in a landfill.

Biogenic: Produced by the actions of living organisms.

Biomass: Materials that are biological in origin, including organic material (both living and dead) from above and below ground, for example, trees, crops, grasses, tree litter, roots, and animals and animal waste.

Biosphere: The portion of the Earth and its atmosphere that can support life. The part of the global carbon cycle that includes living organisms and biogenic organic matter.

Bituminous coal: A dense, black, soft coal, often with well-defined bands of bright and dull material. The most common coal, with moisture content usually less than 20 percent. Used for generating electricity, making coke, and space heating.

$\mathrm{BOD}_{5}$ : The biochemical oxygen demand of wastewater during decomposition occurring over a 5-day period. A measure of the organic content of wastewater. 
Bromofluorocarbons (halons): Inert, nontoxic chemicals that have at least one bromine atom in their chemical makeup. They evaporate without leaving a residue and are used in fire extinguishing systems, especially for large computer installations.

Bunker fuel: Fuel supplied to ships and aircraft in international transportation, irrespective of the flag of the carrier, consisting primarily of residual fuel oil for ships and distillate and jet fuel oils for aircraft.

Calcination: A process in which a material is heated to a high temperature without fusing, so that hydrates, carbonates, or other compounds are decomposed and the volatile material is expelled.

Calcium sulfate: A white crystalline salt, insoluble in water. Used in Keene's cement, in pigments, as a paper filler, and as a drying agent.

Calcium sulfite: A white powder, soluble in dilute sulfuric acid. Used in the sulfite process for the manufacture of wood pulp.

Capital stock: Property, plant and equipment used in the production, processing and distribution of energy resources.

Carbon black: An amorphous form of carbon, produced commercially by thermal or oxidative decomposition of hydrocarbons and used principally in rubber goods, pigments, and printer's ink.

Carbon budget: The balance of the exchanges (incomes and losses) of carbon between carbon reservoirs (e.g., atmosphere and biosphere) in the carbon cycle.

Carbon cycle: All carbon reservoirs and exchanges of carbon from reservoir to reservoir by various chemical, physical, geological, and biological processes. Usually thought of as a series of the four main reservoirs of carbon interconnected by pathways of exchange. The four reservoirs, regions of the Earth in which carbon behaves in a systematic manner, are the atmosphere, terrestrial biosphere (usually includes freshwater systems), oceans, and sediments (includes fossil fuels). Each of these global reservoirs may be subdivided into smaller pools, ranging in size from individual communities or ecosystems to the total of all living organisms (biota).

Carbon dioxide: A colorless, odorless, non-poisonous gas that is a normal part of the ambient air. Carbon dioxide is a product of fossil-fuel combustion. Although $\mathrm{CO}_{2}$ does not directly impair human health, it is a greenhouse gas that traps the earth's heat and contributes to the potential for global warming.
Carbon dioxide equivalent: The concentration of carbon dioxide that would cause the same amount of radiative forcing as a given mixture of carbon dioxide and other greenhouse gases. Carbon dioxide equivalents are generally computed by multiplying the amount (in kilograms) of the gas of interest (for example, methane) by its estimated global warming potential. Some analysts (and this report) use "carbon equivalent units" for convenience, defined as carbon dioxide equivalents multiplied by the carbon content of carbon dioxide (i.e., 12/44).

\section{Carbon flux: See carbon budget.}

Carbon sink: A reservoir that absorbs or takes up released carbon from another part of the carbon cycle. Vegetation and soils are common carbon sinks.

Catalytic converter: A device containing a catalyst for converting automobile exhaust into mostly harmless products.

Cess pool: An underground reservoir for liquid waste, typically household sewage.

Chlorofluorocarbons (CFCs): A family of inert, nontoxic, easily liquefied chemicals used in refrigeration, air conditioning, packaging, and insulation, or as solvents or aerosol propellants.

Climate: The average course or condition of the weather over a period of years as exhibited by temperature, humidity, wind velocity, and precipitation.

Clinker: Powdered cement, produced by heating a properly proportioned mixture of finely ground raw materials (calcium carbonate, silica, alumina, and iron oxide) in a kiln to a temperature of about $2,700^{\circ} \mathrm{F}$.

Cloud condensation nuclei: Aerosol particles that provide a platform for the condensation of water vapor, resulting in clouds with higher droplet concentrations and increased albedo.

Coal coke: A hard, porous product made by baking bituminous coal in ovens at temperatures as high as $2,000^{\circ} \mathrm{F}$. Used both as a fuel and as a reducing agent in blast furnaces. The term "coal coke" is used instead of "coke" to distinguish it from petroleum coke.

Coalbed methane: Methane produced from coalbeds in the same way that natural gas is produced from other strata. See methane.

Combustion: Chemical oxidation accompanied by the generation of light and heat.

Combustion chamber: An enclosed vessel in which chemical oxidation of fuel occurs. 
Cracking: The refining process of breaking down the larger, heavier, and more complex hydrocarbon molecules into simpler and lighter molecules.

Criteria pollutant: A pollutant determined to be hazardous to human health and regulated under EPA's National Ambient Air Quality Standards. The 1970 amendments to the Clean Air Act require EPA to describe the health and welfare impacts of a pollutant as the "criteria" for inclusion in the regulatory regime.

Crop residue: Organic residue remaining from the harvesting and processing of a crop.

Cultivar: A horticulturally or agriculturally derived variety of a plant.

Deforestation: The removal of forest stands.

Degasification system: The methods employed for removing methane from a coal seam that could not otherwise be removed using standard ventilation fans and thus would pose a substantial hazard to coal miners. These systems may be used prior to mining or during mining activities.

Degradable organic carbon: The portion of organic carbon, present in such solid waste as paper, food waste, and yard waste, that is susceptible to biochemical decomposition.

Desulfurization: The removal of sulfur, as from molten metals, petroleum oil, or flue gases.

Diffusive transport: The process by which particles of liquids or gases move from an area of higher concentration to an area of lower concentration.

Distillate fuel: A general classification for the petroleum fractions produced in conventional distillation operations. Included are products known as No. 1, No. 2, and No. 4 fuel oils and No. 1, No. 2, and No. 4 diesel fuels. Used primarily for space heating, on- and offhighway diesel engine fuel (including railroad engine fuel and fuel for agricultural machinery), and electric power generation.

Efflux: An outward flow.

Electrical generating capacity: The full-load continuous power rating of electrical generating facilities, generators, prime movers, or other electric equipment (individually or collectively).

EMCON Methane Generation Model: A model for estimating the production of methane from municipal solid waste landfills.

Emissions: Anthropogenic (human-caused) releases of greenhouse gases to the atmosphere (e.g., the release of carbon dioxide during fuel combustion).
Emissions coefficient/factor: $A$ unique value for scaling emissions to activity data in terms of a standard rate of emissions per unit of activity (e.g., pounds of carbon dioxide emitted per barrel of fossil fuel consumed).

Enteric fermentation: A digestive process by which carbohydrates are broken down by microorganisms into simple molecules for absorption into the bloodstream of an animal.

Eructation: An act or instance of belching.

Ethyl tertiary butyl ether (ETBE): A colorless, flammable, oxygenated hydrocarbon blend stock.

Ethylene: An olefinic hydrocarbon recovered from refinery or petrochemical processes.

Ethylene dichloride: A colorless, oily liquid used as a solvent and fumigant for organic synthesis, and for ore flotation.

Facultative bacteria: Bacteria that grow equally well under aerobic and anaerobic conditions.

Flange: A rib or a rim for strength, for guiding, or for attachment to another object (e.g., on a pipe).

Flared natural gas: Natural gas burned in flares on the well site or at gas processing plants.

Flatus: Gas generated in the intestines or the stomach of an animal.

Flue gas desulfurization: Equipment used to remove sulfur oxides from the combustion gases of a boiler plant before discharge to the atmosphere. Also referred to as scrubbers. Chemicals such as lime are used as scrubbing media.

Fluidized-bed combustion: A method of burning particulate fuel, such as coal, in which the amount of air required for combustion far exceeds that found in conventional burners. The fuel particles are continually fed into a bed of mineral ash in the proportions of 1 part fuel to 200 parts ash, while a flow of air passes up through the bed, causing it to act like a turbulent fluid.

Flux material: A substance used to promote fusion, e.g., of metals or minerals.

Fodder: Coarse food for domestic livestock.

Forestomach: See rumen.

Fossil fuel: Any naturally occurring organic fuel formed in the Earth's crust, such as petroleum, coal, or natural gas.

Fuel cycle: The entire set of sequential processes or stages involved in the utilization of fuel, including extraction, transformation, transportation, and combustion. Emissions generally occur at each stage of the fuel cycle. 
Fugitive emissions: Unintended leaks of gas from the processing, transmission, and/or transportation of fossil fuels.

Gasification: A method for exploiting poor-quality coal and thin coal seams by burning the coal in place to produce combustible gas that can be collected and burned to generate power or processed into chemicals and fuels.

Gate station: Location where the pressure of natural gas being transferred from the transmission system to the distribution system is lowered for transport through small diameter, low pressure pipelines.

Geothermal: Pertaining to heat within the Earth.

Global warming potential (GWP): The instantaneous radiative forcing that results from the addition of 1 kilogram of a gas to the atmosphere, relative to that of 1 kilogram of carbon dioxide.

Greenhouse effect: A popular term used to describe the roles of water vapor, carbon dioxide, and other gases in keeping the Earth's surface warmer than it would otherwise be. These radiatively active gases are relatively transparent to incoming shortwave radiation, but are relatively opaque to outgoing longwave radiation. The latter radiation, which would otherwise escape to space, is trapped by greenhouse gases within the lower levels of the atmosphere. The subsequent reradiation of some of the energy back to the-Earth maintains higher surface temperatures than would occur if the gases were absent. There is concern that increasing concentrations of greenhouse gases, including carbon dioxide, methane, and chlorofluorocarbons, may enhance the greenhouse effect and cause global warming.

Greenhouse gases: Those gases, such as water vapor, carbon dioxide, tropospheric ozone, nitrous oxide, and methane, that are transparent to solar radiation but opaque to longwave radiation, thus preventing longwave radiation energy from leaving the atmosphere. The net effect is a trapping of absorbed radiation and a tendency to warm the planet's surface.

Gross gas withdrawal: The full-volume of compounds extracted at the wellhead, including nonhydrocarbon gases and natural gas plant liquids.

Gypsum: The most common sulfate mineral. Used in wallboard.

Halogenated substances: A volatile compound containing halogens, such as chlorine, fluorine or bromine.

Halons: See bromofluorocarbons.
Heating degree-day: The number of degrees per day that the average daily temperature is below 65 degrees Fahrenheit.

Herbivore: A plant-eating animal.

Hydrocarbon: An organic chemical compound of hydrogen and carbon in either gaseous, liquid, or solid phase. The molecular structure of hydrocarbon compounds varies from the simple (e.g., methane, a constituent of natural gas) to the very heavy and very complex.

Hydrochlorofluorocarbons (HCFCs): Chemicals composed of one or more carbon atoms and varying numbers of hydrogen, chlorine, and fluorine atoms.

Hydrofluorocarbons (HFCs): Chemicals composed of one or two carbon atoms and varying numbers of hydrogen and fluorine atoms.

Hydroxyl radical (OH): An important chemical scavenger of many trace gases in the atmosphere that are greenhouse gases. Atmospheric concentrations of $\mathrm{OH}$ affect the atmospheric lifetimes of greenhouse gases, their abundance, and, ultimately, the effect they have on climate.

Intergovernmental Panel on Climate Change (IPCC): A panel established jointly in 1988 by the World Meteorological Organization and the United Nations Environment Program to assess the scientific information relating to climate change and to formulate realistic response strategies.

Jet fuel: Kerosene- and naphtha-type fuels for jet engines. Kerosene-type jet fuel is a kerosene-quality product used primarily for commercial turbojet and turboprop aircraft engines. Naphtha-type jet fuel is a fuel in the heavy naphtha range used primarily for military turbojet and turboprop aircraft engines.

Kerosene: $\mathrm{A}$ petroleum distillate that has a maximum distillation temperature of $401^{\circ} \mathrm{F}$ at the 10 -percent recovery point, a final boiling point of $572^{\circ} \mathrm{F}$, and a minimum flash point of $100^{\circ} \mathrm{F}$. Used in space heaters, cookstoves, and water heaters, and suitable for use as an illuminant when burned in wick lamps.

Ketone-alçohol (cyclohexanol): An oily, colorless, hygroscopic liquid with a camphor-like odor. Used in soapmaking, dry cleaning, plasticizers, insecticides, and germicides.

Leachate: A liquid produced as water percolates through wastes, collecting contaminants.

Lignite: A brownish-black coal of low rank with high inherent moisture and volatile matter content, used almost exclusively for electric power generation. Also referred to as brown coal. 
Liquefied petroleum gases (LPG): Ethane, ethylene, propane, propylene, normal butane, butylene, and isobutane produced at refineries or natural gas processing plants, including plants that fractionate new natural gas plant liquids.

Lubricant: A substance used to reduce friction between bearing surfaces or as a process material, either incorporated into other materials used as aids in manufacturing processes or as carriers of other materials. Petroleum lubricants may be produced either from distillates or residues. Other substances may be added to impart or improve useful properties. Does not include byproducts of lubricating oil from solvent extraction or tars derived from deasphalting. Lubricants include all grades of lubricating oils from spindle oil to cylinder oil and those used in greases. Lubricant categories are paraffinic and naphthenic.

Methane: A hydrocarbon gas $\left(\mathrm{CH}_{4}\right)$ that is the principal constituent of natural gas.

Methanogens: Bacteria that synthesize methane, requiring completely anaerobic conditions for growth.

Methanol: A light alcohol that can be used for gasoline blending. See oxygenate.

Methanotrophs: Bacteria that use methane as food and oxidize it into carbon dioxide.

Methyl chloroform (trichloroethane): An industrial chemical $\left(\mathrm{CH}_{3} \mathrm{CCl}_{3}\right)$ used as a solvent, aerosol propellant, and pesticide and for metal degreasing.

Methyl tertiary butyl ether (MTBE): A colorless, flammable, liquid oxygenated hydrocarbon containing 18.15 percent oxygen.

Methylene chloride: A colorless liquid, nonexplosive and practically nonflammable. Used as a refrigerant in centrifugal compressors, a solvent for organic materials, and a component in nonflammable paint removers.

Mole: The quantity of a compound or element that has a weight in grams numerically equal to its molecular. weight. Also referred to as gram molecule or gram molecular weight.

Montreal Protocol: The Montreal Protocol on Substances that Deplete the Ozone Layer (1987). An international agreement, signed by most of the industrialized nations, to substantially reduce the use of chlorofluorocarbons (CFCs). Signed in January 1989, the original document called for.a 50-percent reduction in CFC. use by 1992 relative to 1986 levels. The subsequent London Agreement called for a complete elimination of CFC use by 2000 . The yet-to-be-ratified Copenhagen Agreement calls for a complete phaseout by January 1 , 1996.
Motor gasoline: A complex mixture of relatively volatile hydrocarbons, with or without small quantities of additives, obtained by blending appropriate refinery streams to form a fuel suitable for use in spark-ignition engines. Motor gasoline includes both leaded and unleaded grades of finished gasoline, blending components, and gasohol.

Multiple cropping: A system of growing several crops on the same field in one year.

Municipal solid waste: Residential solid waste and some nonhazardous commercial, institutional, and industrial wastes.

Naphtha: A generic term applied to a petroleum fraction with an approximate boiling range between 122 and $400^{\circ} \mathrm{F}$.

Natural gas: A mixture of hydrocarbons and small quantities of various nonhydrocarbons in the gaseous phase or in solution with crude oil in natural underground reservoirs.

Natural gas liquids (NGLs): Those hydrocarbons in natural gas that are separated as liquids from the gas. Includes natural gas plant liquids and lease condensate.

Natural gas, pipeline quality: A mixture of hydrocarbon compounds existing in the gaseous phase with sufficient energy content, generally above $900 \mathrm{Btu}$, and a small enough share of impurities for transport through commercial gas pipelines and sale to end-users. Nitrogen oxides $\left(\mathrm{NO}_{\mathrm{x}}\right)$ : Compounds of nitrogen and oxygen produced by the burning of fossil fuels:

Nonmethane volatile organic compounds (NMVOCs): Organic compounds, other than methane, that participate in atmospheric photochemical reactions.

Octane: A flammable liquid hydrocarbon found in petroleum. Used as a standard to measure the antiknock properties of motor fuel.

Oil reservoir: An underground pool of liquid consisting of hydrocarbons, sulfur, oxygen, and nitrogen trapped within a geological formation and protected from evaporation by the overlying mineral strata.

Organic content: The share of a substance that is of animal or plant origin.

Organic waste: Waste material of animal or plant origin.

Oxidize: To chemically transform a substance by combining it with oxygen.

Oxygenate: A substance which, when added to gasoline, increases the amount of oxygen in that gasoline blend. Includes fuel ethanol, methanol, and methyl tertiary butyl ether (MTBE). 
Ozone: A molecule made up of three atoms of oxygen. Occurs naturally in the stratosphere and provides a protective layer shielding the Earth from harmful ultraviolet radiation. In the troposphere, it is a chemical oxidant, a greenhouse gas, and a major component of photochemical smog.

Ozone precursors: Chemical compounds, such as carbon monoxide, methane, nonmethane hydrocarbons, and nitrogen oxides, which in the presence of solar radiation react with other chemical compounds to form ozone.

Paraffinic hydrocarbons: Straight-chain hydrocarbon compounds with the general formula $\mathrm{C}_{n} \mathrm{H}_{2 n+2}$.

Perfluorocarbons (PFCs): Chemicals composed of one or two carbon atoms and four to six fluorine atoms, containing no chlorine. PFCs have no commercial uses and are emitted as a byproduct of aluminum smelting.

Perfluoromethane: A compound $\left(\mathrm{CF}_{4}\right)$ emitted as a byproduct of aluminum smelting.

Petrochemical feedstock: Feedstock derived from petroleum, used principally for the manufacture of chemicals, synthetic rubber, and a variety of plastics. The categories reported are naphthas (endpoint less than $401^{\circ} \mathrm{F}$ ) and other oils (endpoint equal to or greater than $401^{\circ} \mathrm{F}$ ).

Petroleum: Hydrocarbon mixtures, including crude oil, lease condensate, natural gas, products of natural gas processing plants, refined products, semifinished products, and blending materials.

Petroleum coke: A residue that is the final product of the condensation process in cracking.

Photosynthesis: The manufacture by plants of carbohydrates and oxygen from carbon dioxide and water in the presence of chlorophyll, with sunlight as the energy source. Carbon is sequestered and oxygen and water vapor are released in the process.

Pig iron: Crude, high-carbon iron produced by reduction of iron ore in a blast furnace.

Pipeline, distribution: Pipeline that conveys gas from a transmission pipeline to ultimate consumer.

Pipeline, gathering: A pipeline that conveys gas from a production well/field to a gas processing plant or transmission pipeline for eventual delivery to end-use consumers.

Pipeline, transmission: A pipeline that conveys gas from region where it is produced to region where it is to be distributed
Planetary albedo: The fraction of incident solar radiation that is reflected by the Earth-atmosphere system and returned to space, mostly by backscatter from clouds in the atmosphere.

Pneumatic device: A device moved or worked by air pressure.

Polystyrene: A polymer of styrene that is a rigid, transparent thermoplastic with good physical and electrical insulating properties which is used in molded products, foams, and sheet materials.

Polyvinyl chloride (PVC): A polymer of vinyl chloride. Tasteless odorless, insoluble in most organic solvents. A member of the family vinyl resin, used in soft flexible films for food packaging and in molded rigid products such as pipes, fibers, upholstery, and bristles.

Post-mining emissions: Emissions of methane from a coal mine occurring after the coal has been mined, occurring during transport or pulverization.

Radiative forcing: The extent to which emitting a greenhouse gas into the atmosphere raises global average temperature.

Radiatively active gases: Gases that absorb incoming solar radiation or outgoing infrared radiation, affecting the vertical temperature profile of the atmosphere.

Ratoon crop: A crop cultivated from the shoots of a perennial plant.

Redox potential: A measurement of the state of oxidation of a system.

Reflectivity: The ratio of the energy carried by a wave after reflection from a surface to its energy before reflection.

Reforestation: Replanting of forests on lands that have recently been harvested.

Reformulated gasoline: Gasoline formulated for use in motor vehicles, the composition and properties of which meet the requirements of the reformulated gasoline regulations promulgated by the U.S. Environmental Protection Agency under Section 211K of the Clean Air Act.

Renewable energy: Energy obtained from sources that are essentially inexhaustible (unlike, for example, the fossil fuels, of which there is a finite supply). Renewable' sources of energy include wood, waste, geothermal, wind, photovoltaic, and solar thermal energy. 
Residual fuel oil: The heavier oils that remain after the distillate fuel oils and lighter hydrocarbons are distilled away in refinery operations and that conform to ASTM Specifications D396 and D975. Included are No. 5, a residual fuel oil of medium viscosity; Navy Special, for use in steam-powered vessels in government service and in shore power plants; and No. 6, which includes Bunker $C$ fuel oil and is used for commercial and industrial heating, electricity generation, and to power ships. Imports of residual fuel oil include imported crude oil burned as fuel.

Rumen: The large first compartment of the stomach of certain animals in which cellulose is broken down by the action of bacteria.

Sample: A set of measurements or outcomes selected from a given population.

Sequestration: The fixation of atmospheric carbon dioxide in a carbon sink through biological or physical processed, such as photosynthesis.

Septic tank: A tank in which the solid matter of continuously flowing sewage is disintegrated by bacteria.

Sinter: A chemical sedimentary rock deposited by precipitation from mineral waters, especially siliceous sinter and calcareous sinter.

Sodium silicate: A grey-white powder soluble in alkali and water, insoluble in alcohol and acid. Used to fireproof textiles, in petroleum refining and corrugated paperboard manufacture, and as an egg preservative. Also referred to as liquid gas, silicate of soda, sodium metasilicate, soluble glass, and water glass.

Sodium tripolyphosphate: A white powder used for water softening and as a food additive and texturizer.

Stabilization lagoon: A shallow artificial pond used for the treatment of wastewater. Treatment includes removal of solid material through sedimentation, the decomposition of organic material by bacteria, and the removal of nutrients by algae.

Still gas: Any form or mixture of gases produced in refineries by distillation, cracking, reforming, and other processes. Principal constituents are methane, ethane, ethylene, normal butane, butylene, propane, propylene, etc. Used as a refinery fuel and as a petrochemical feedstock.

Stratosphere: The region of the upper atmosphere extending from the tropopause $(8$ to 15 kilometers altitude) to about 50 kilometers. Its thermal structure, which is determined by its radiation balance, is generally very stable with low humidity.
Stripper well: A well that produces 60 million cubic feet of gas per day or less for a period of three consecutive months while producing at its maximum flow rate.

Styrene: A colorless, toxic liquid with a strong aromatic aroma. Insoluble in water, soluble in alcohol and ether; polymerizes rapidly; can become explosive. Used to make polymers and copolymers, polystyrene plastics, and rubber.

Subbituminous coal: A dull, black coal of rank intermediate between lignite and bituminous coal.

Sulfur dioxide: A toxic, irritating, colorless gas soluble in water, alcohol, and ether. Used as a chemical intermediate, in paper pulping and ore refining, and as a solvent.

Sulfur hexafluoride: A colorless gas soluble in alcohol and ether, slightly soluble in water. Used as a dielectric in electronics.

Sulfur oxides $\left(\mathrm{SO}_{\mathrm{x}}\right)$ : Compounds containing sulfur and oxygen, such as sulfur dioxide $\left(\mathrm{SO}_{2}\right)$ and sulfur trioxide $\left(\mathrm{SO}_{3}\right)$.

Tertiary amyl methyl ether (TAME): An oxygenate blend stock formed by the catalytic etherification of isoamylene with methanol.

Troposphere: The inner layer of the atmosphere below about 15 kilometers, within which there is normally a steady decrease of temperature with increasing altitude. Nearly all clouds form and weather conditions manifest themselves within this region. Its thermal structure is caused primarily by the heating of the Earth's surface by solar radiation, followed by heat transfer through turbulent mixing and convection.

Uncertainty: A measure used to quantify the plausible maximum and minimum values for emissions from any source given the biases inherent in the methods used to calculate a point estimate known sources of error.

Vapor displacement: The release of vapors that had previously occupied space above liquid fuels stored in tanks. These releases occur when tanks are emptied and filled.

Ventilation system: A method for reducing methane concentrations in coal mines to non-explosive levels by blowing air across the mine face and using large exhaust fans to remove methane while mining operations proceed.

Volatile organic compounds (VOCs): Organic compounds that participate in atmospheric photochemical reactions.

Volatile solids: A solid material that is readily decomposable at relatively low temperatures. 
Waste flow: Quantity of a waste stream generated by an activity.

Wastewater: Water that has been used and contains dissolved or suspended waste materials.

Wastewater, domestic and commercial: Wastewater (sewage) produced by domestic and commercial establishments.

Wastewater, industrial: Wastewater produced by industrial processes.

Water vapor: Water in a vaporous form, especially when below boiling temperature and diffused (e.g., in the atmosphere).

Waxes: Solid or semisolid materials derived from petroleum distillates or residues. Light-colored, more or less translucent crystalline masses, slightly greasy to the touch, consisting of a mixture of solid hydrocarbons in which the paraffin series predominates. Included are all marketable waxes, whether crude scale or fully refined. Used primarily as industrial coating for surface protection.
Weanling system: A cattle management system that places calves on feed starting at 165 days of age and continues until the animals have reached slaughter weight.

Wellhead: The top of, or a structure built over, a well.

Wetlands: Areas regularly saturated by surface or groundwater and subsequently characterized by a prevalence of vegetation adapted for life in saturatedsoil conditions.

Wood energy: Wood and wood products used as fuel, including roundwood (cordwood), limbwood, wood chips, bark, sawdust, forest residues, and charcoal.

Yearling system: A cattle management system that includes a stocker period from 165 days of age to 425 days of age followed by a 140 day feedlot period. 


\section{Census Catalog and Guide: 1996}

The U.S. Census Bureau announces its 315-page One-Stop Guide to all kinds of statistics!

It provides the detail you'll need to choose the right products. And it covers everything from the Census Bureau, mid-1993 through 1995 - plus tells how to get free monthly updates!

\section{Want More?}

You'll find thousands of phone numbers and addresses for easy access to information and assistance. Why pass up help-State or local, public or private?

Also, the catalog guides you to online data, CD-ROM's, printed reports, floppy disks, and computer tape from:

1992 Economic Census

Current Surveys of Population and Housing Plus all our other topics too-

$\square$ Agriculture
$\square$ Business
$\square$ Communications
$\square$ Construction
$\square$ Finance
$\square$ Foreign Trade
$\square$ Geography
$\square$ Governments

$\square$ Insurance
$\square$ International
$\square$ Manufacturing
$\square$ Mineral Industries
$\square$ Real Estate
$\square$ Transportation
$\square$ Utilities

(For immediate information about ordering the products pictured at right, call the U.S. Census Bureau at $301-457-4100$ )

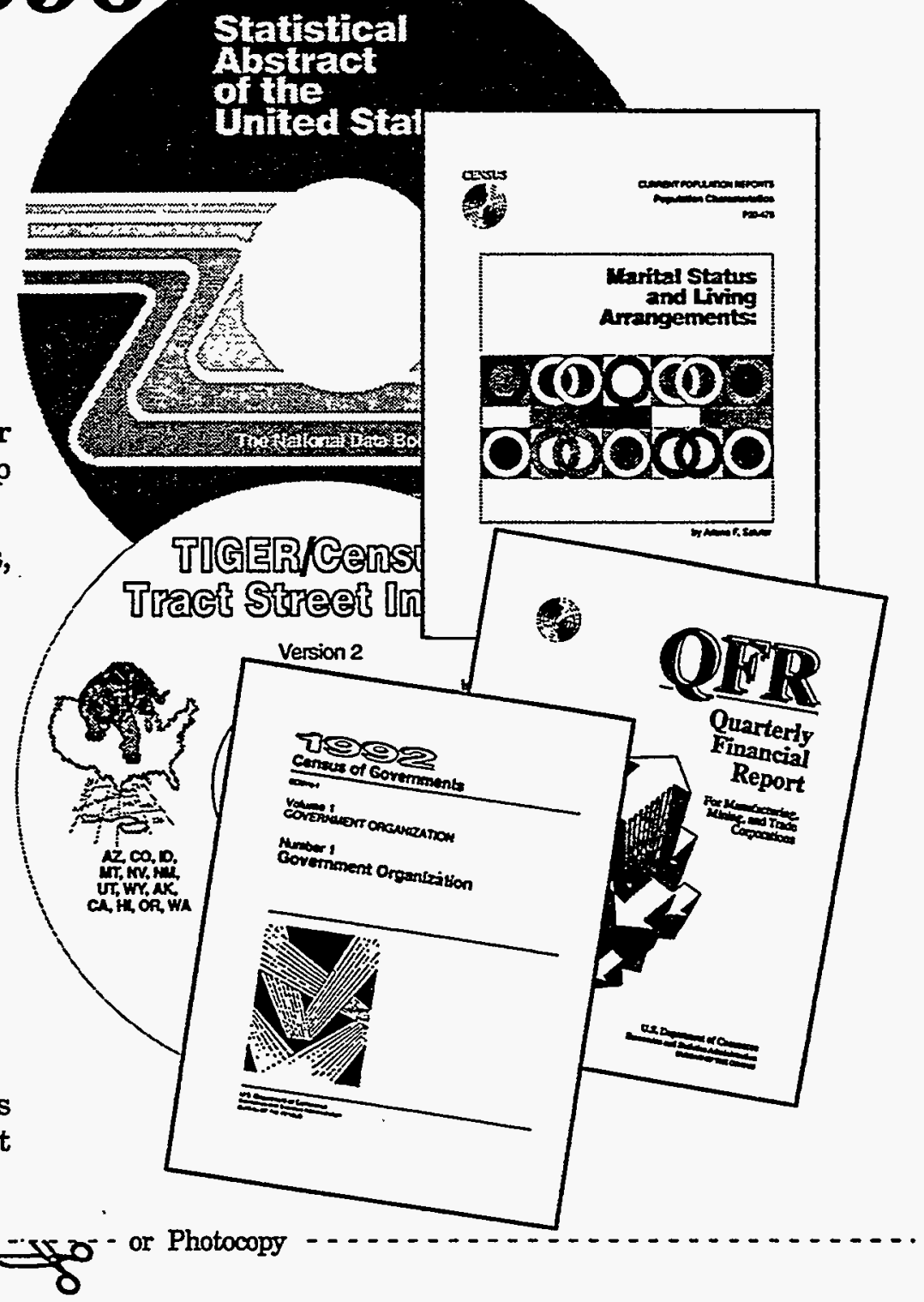

Order Processing Code:

*7898

Superintendent of Documents Publications Order Form

YES, please send me the following:

copies of

Census Catalog and Guide: 1996, S/N 003-024-08804-5. at $\$ 21.00$ each ( $\$ 26.25$ foreign)
Charge your order:

It's easy!

To fax your orders 202-512-2250

To phone your orders 202-512-1800

The total cost of my order is $\$$ . Price includes regular shipping and handling and is subject to change.

Company or personal name

(Please type or print)

Additional address/attention line

Street address

City, State, ZIP Code

Daytime phone including area code

Purchase order number (optional)
Check method of payment:

$\square$ Check payable to the Superintendent of Documents

$\square$ GPO deposit account

$\square$ VISA $\square$ MasterCard

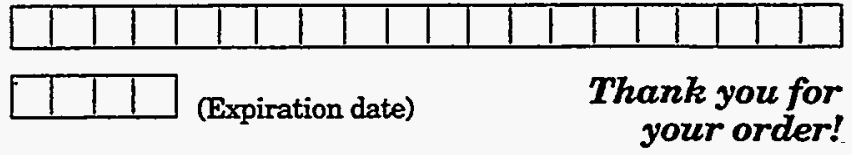

(Authorizing signature)

Mail To: Superintendent of Documents

P.O. Box 371954, Pittsburgh, PA 15250-7954 
